Göttinger

Bibliotheksschriften

Band 39

\title{
Central Asian Sources and \\ Central Asian Research
}

edited by

Johannes Reckel

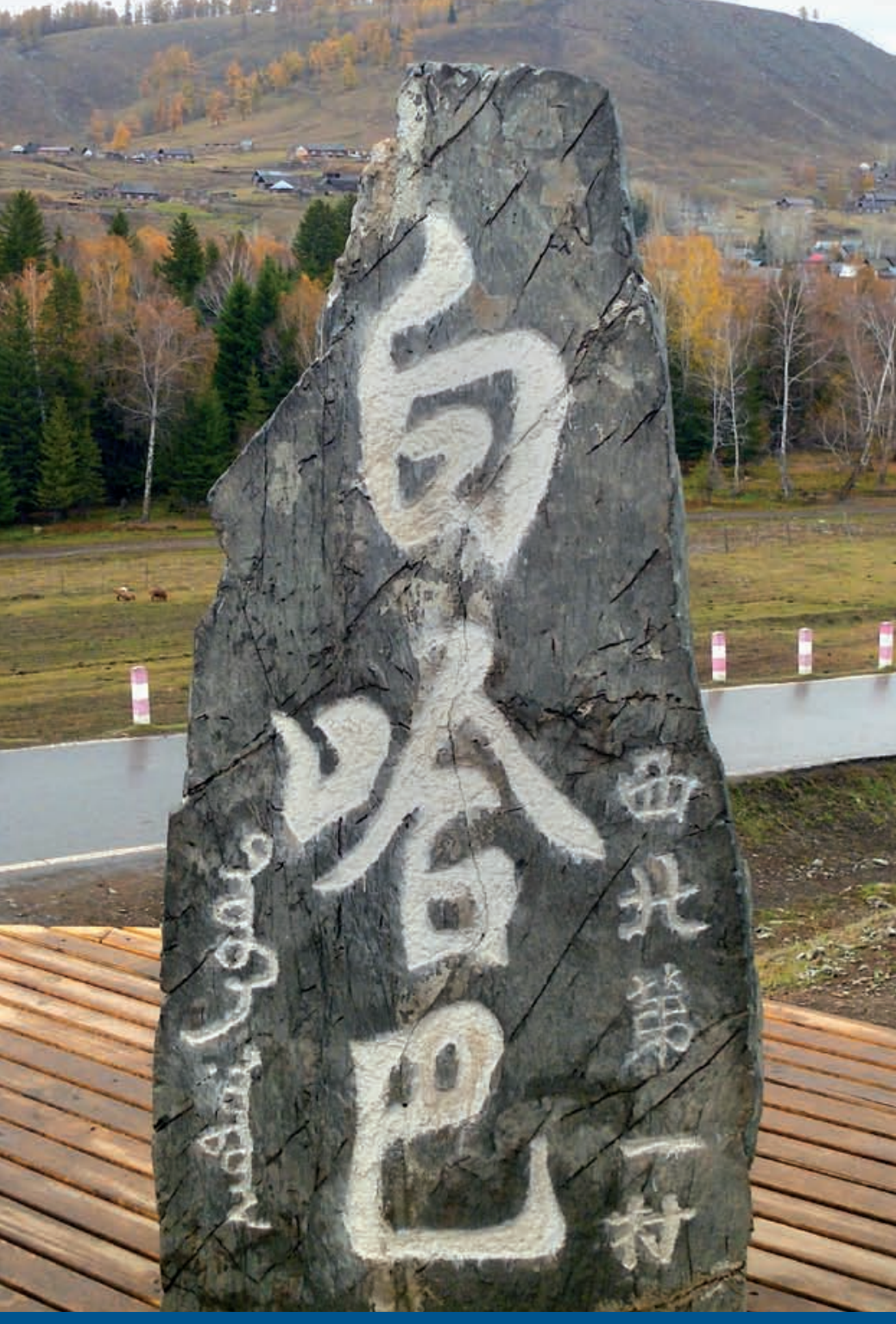



Johannes Reckel (ed.)

Central Asian Sources and Central Asian Research

This work is licensed under a Creative Commons Attribution-ShareAlike 4.0 International License.

(c) $)_{\mathrm{BY}} \mathrm{SP}_{\mathrm{SA}}$ 
Published as Volume 39 of the series "Göttinger Bibliotheksschriften" by Universitätsverlag Göttingen 2016 
Johannes Reckel (ed.)

\section{Central Asian Sources and Central Asian Research}

Selected Proceedings from the International Symposium "Central Asian Sources and Central Asian Research", October $23^{\text {rd }}-26^{\text {th }}, 2014$ at Göttingen State and University Library

Göttinger Bibliotheksschriften Volume 39

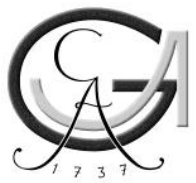

Universitätsverlag Göttingen 2016 
Bibliographic information published by the Deutsche Nationalbibliothek

The Deutsche Nationalbibliothek lists this publication in the Deutsche

Nationalbibliografie; detailed bibliographic data are available on the Internet at http://dnb.dnb.de.

Göttinger Bibliotheksschriften

edited by

Dr Wolfram Horstmann

Niedersächsische Staats- und Universitätsbibliothek Göttingen

Platz der Göttinger Sieben 1

D-37073 Göttingen

This work is protected by German Intellectual Property Right Law.

It is also available as an Open Access version through the publisher's homepage and the Göttingen University Catalogue (GUK) at the Göttingen State and University

Library (http://www.sub.uni-goettingen.de).

The license terms of the online version apply.

Set and layout: Petra Lepschy

Cover image (Johannes Reckel): The Khazak-Tuva village of "Bai Haba, the first village of the (Chinese) Northwest" in the Altai Mountains

(C) 2016 Universitätsverlag Göttingen

http://univerlag.uni-goettingen.de

ISBN: 978-3-86395-272-3

ISSN: 0943-951X 


\section{Contents}

$\begin{array}{ll}\text { Preface } & 7\end{array}$

Introduction: Central Asian written sources - from manuscript and print culture into the digital Dark Ages?

Johannes Reckel (Göttingen)

A preliminary survey of the keyimori in Ordos

Ayalagu (Beijing)

Iy̌il Cürüm from Kalmyckia and his role in transforming the Oirat script in Xinjiang during the early $20^{\text {th }}$ century Ba. Batubayar (Urumchi).

Gábor Bálint's Manuscripts of the 19th Century Kalmyk and Khalkha

Vernacular Kept in the Hungarian Academy of Sciences

Agnes Birtalan (Budapest) 51

News on manuscripts of Rabghūzī’s Qịsaṣu 1-Anbiyā'

Hendrik Boeschoten (Main₹).

The Making of the Pentaglot: Concepts, Data Structures and Tools

Oliver Corff (Berlin) 73

Chinese sources on the modern history of Xinjiang: reading the Kashi shi wenshi ziliao

Michael Dillon (Worksop)

Oirat Texts written in the Clear Script (todo üsüg) preserved at the Ili River in Xinjiang Erdemtu Minggad (Beijing).....

Mongolian Voices of Discontent in Lifanyuan Records of the early Qing-period Dorothea Heuschert-Laage (Bern) 111 
Kontinuität in der Phraseologie des Alt- und Neuuigurischen vom 14. bis zum 20. Jahrhundert

Aysima Mirsultan (Berlin).

The Symbolism of "čarayana", "tamarisk", and "tabilqai" occuring in Mongolian customs

T. Namjil (Urumchi)

The Sino-Mongolian Glossary Dada yu/Beilu yiyu from the Ming Period and the Problem of its Dating Pavel Rykin (Moscow)

The Manchu-Mongolian letters between Tibet and Qing-China from the collection Daicing gürün-ü mongyol bicig-ün ger-ün dangse Andreas Siegl (Munich)

The Nobility of the Altai Urianhai Banners in Archive Documents and Oral Tradition

Ondrej Srba (Prague)

Cornelius Rahmn - pioneer of Kalmuck linguistics Jan-Olof Svantesson (Lund)

Block printing in the Buddhist Monasteries of Transbaikalia in the $19^{\text {th }}$ and early $20^{\text {th }}$ centuries: current archeography of the texts Surun-Khanda D. Syrtypova (Moscow)

Cataloguing the Berlin Manchu Collection

Hartmut Walravens (Berlin) 


\section{Preface}

In October 2014 about thirty scholars from Asia and Europe came together for a conference to discuss different kinds of sources for the research on Central Asia. Göttingen State and University Library (SUB Göttingen) with its old collections of oriental literature by Thomas v. Asch and Johann David Michaelis and others from the $18^{\text {th }}$ century onward has always been an ideal place for orientalists to meet and conduct research.

Göttingen State and University Library also houses the largest modern collection of literature from Central Asia and Siberia in Germany collected over many decades with financial support of the German Research Foundation within the framework of the special collection (Sondersammelgebiet) "Altaic and Palaeoasiatic languages, literatures and cultures". About 20,000 titles in Mongolian languages, over 7,000 titles in the Uighur language and an internationally renowned collection of literature from Sinkiang in general makes it a center for Central Asian Studies in Europe. A joint project between the SUB Göttingen and the Harvard-Yenching Library for the digitization of older newspapers from Sinkiang connects us with the University Library in Lund, which houses the Gunnar Jarring Collection, offering a continuation into the past of the more modern Sinkiang collection of Göttingen. Furthermore, the Göttingen Academy of Sciences and Humanities houses the longtime project "Wörterbuch des Altuigurischen" ("Dictionary of Old Uighur"), focusing on pre-Islamic Uighur literature. During the conference in 2014 Sinkiang and the Mongols were the two main focus points.

The image for the cover of this volume has been chosen accordingly, showing the center of the Altaic world: The Khazak-Tuva village of "Bai Haba (i. e. White River, bai is Chinese for "white", haba is Mongolian for a deep-cut fast-flowing river), the first village of the (Chinese) Northwest" in the Altai Mountains. Left side on the stone in Mongolian script: "Tuba nutuy" (i. e. Tuva home country). The Tuva are a Turkish people living in the Altai Mountains of Mongolia, China, 
Russia, Kazakhstan. Here the Mongolian and the Turkic world mix freely like in the rest of Central Asia. ${ }^{1}$

The dominating theme of the whole conference was the importance of collections of source material found in libraries and archives, their preservation and expansion for future generations of scholars. Some of the finest presentations were selected for this volume and are now published for a wider audience.

Göttingen, November 2016

Johannes Reckel

${ }^{1}$ Cf. Reckel, Johannes: Reisenotizen aus der Westmongolei und dem Altai. In: Mongolische Notizen Nr. 24/2016, pp. 10-17. Deutsch-Mongolische Gesellschaft, Bonn, 2016 


\section{Introduction: \\ Central Asian written sources - from manuscript and print culture into the digital Dark Ages?}

Johannes Reckel (Georg-August-Universität Göttingen)

Central Asia, a region defined by its culture and history as well as by its nature, is much more difficult to comprehend as an entity than long established regions like East Asia (oriens extremus), the Middle East and Near East, Siberia or the Indian subcontinent. Central Asia sits in between all these named regions without any clear boundaries. It is also called Inner Asia. In Russian and German there is sometimes a distinction made between Middle Asia (Mittelasien, Srednyaya Asiya) and Central Asia (Zentralasien, Zentralnaya Asiya), the former limited to the now independent former Soviet republics of Tajikistan, Uzbekistan, Kazakhstan, Kyrgyzstan, Turkmenistan.

The earliest definition of Central Asia is found in Alexander von Humboldt's work "Asie Centrale" published in 18431. In 1829 Humboldt, aged 60, had lead an expedition from the Caspian Sea, the Ural mountains through Central Asia as far as the Altai mountains on the Chinese border. ${ }^{2}$ Alexander von Humboldt defined Central Asia as a band $5^{\circ}$ north and $5^{\circ}$ south of latitude $44,5^{\circ} \mathrm{N}$. which he consid-

\footnotetext{
${ }^{1}$ Humboldt, Alexander de; Asie Centrale - Recherches Sur Les Chaines De Montagnes Et La Climatologie Comparée Par A. De Humboldt; Paris 1843

${ }^{2}$ Humboldt, Alexander von; Zentral-Asien. Untersuchungen zu den Gebirgsketten und zur vergleichenden Klimatologie. Mit einer Auswahl aus Alexander von Humboldts Reisebriefen und Gustav Roses Reisebericht. Nach der Übers. Wilhelm Mahlmanns aus dem Jahr 1844. Neu bearb. und hrsg. von Oliver Lubrich. S. Fischer, Frankfurt am Main, 2009
} 
ered as the middle parallel of the entire Asian continent, bordered in the east by the Great Khingan mountains of Northwestern Manchuria and in the west by the Ustyurt plateau east of the Caspian Sea. This definition has been challenged many times by Russian, German and other geographers like v. Richthofen, the later using the term Zentralasien for an area between Tibet, the Pamir, the Altai Mountains and the Khingan Mountains and bordered in the east by the system of the large streams of China proper, excluding largely what is now called Middle Asia and only including the eastern half of the area defined by Humboldt as Central Asia. ${ }^{3}$ These definitions had so far been made mainly on a geological-geographical basis, excluding anthropological, ethnological and linguistic considerations.

From 1976 onward the UNESCO prepared and finally from 1992 issued a multi volume History of Civilizations of Central Asia. Central Asia in the UNESCO project included large parts of the then Soviet Union in Middle Asia and including the southern half of Siberia, all Mongolia, Sinkiang and Manchuria and Inner Mongolia and Tibet in China, Afghanistan, parts of Pakistan, Iran and India. ${ }^{4}$ By the definition of the UNESCO Central Asia as defined by Humboldt was kept in its East-West extension but expanded greatly north into Siberia and south into the Himalayas, Hindukush, Pamir etc. This redefinition was and is justified by the civilizations of the peoples living in this region. Modern Scholars like Michael Weiers would include even the whole of Manchuria and the Tungus peoples of Manchuria and Siberia into "Zentralasien". ${ }^{5}$ In the West the steppes north of the Caspian Sea are culturally a continuation of the Central Asian steppes, the nomads living there have the closest links to their Central Asian neighbors and speak languages closely related. The Mongolian Kalmyks or Oirat may be living in Europe, but they are still culturally a part of Central Asia. The definition of the geographic border between Europe and Asia seems artificial. Defining Central Asia is an ongoing process. $^{6}$

Central Asia may be defined by its neighboring civilizations. In the east the Chinese culture, with its strong influence especially of the Chinese writing system and philosophy/religion in Korea, Japan, Vietnam (but not Mongolia) is complimented in the west by the Greek-Byzantine complex with Russia seeing itself as the inheritor of the Byzantine empire. The Persian and the Indian cultural complex lie to the south of Central Asia. These four civilizations represent a cultural continuum spanning more than two millennia. The cultures of the peoples of the Tundra in northern Siberia are different and it is much harder to draw a line be-

\footnotetext{
${ }^{3}$ Richthofen, Ferdinand von; China - Ergebnisse eigener Reisen und darauf gegründeter Studien (5 Textbände und 2 Kartenbände), Berlin 1877-1912

${ }^{4}$ Miroshnikov, L.I.; A note of the meaning of the term 'Central Asia' as used in this book; In: History of Civilizations of Central Asia: The Dawn of Civilization - Earliest Times to 700 B.C., edited by Ahmad Hasan Dani; Paris, UNESCO Publ., 1992, p. 477-480

5 Michael Weiers' website contains his articles and further information on Central Asia: http://www.zentralasienforschung.de/

${ }^{6}$ Fragner, Bert und Kappeler, Andreas (eds); Zentralasien 13. bis 20. Jahrhundert; Geschichte und Gesellschaft, Wien 2006
} 
tween the Tungus Manchu of Manchuria and the Tungus Lamut/Even in northeastern Sibiria. The close ties, culturally and linguistically, between the Mongolian Buryats of Siberia and other Mongolian peoples of Mongolia and elsewhere, or the Siberian Tuvans, Yakuts with Kazakhs or Kirgiz are more obvious.

Culturally Central Asia is different from Greater China, India, the Persian and Greek-Byzantine culture. Its indigenous peoples were mainly nomads and hunters, partly oasis dwellers and merchants along the Silk Road. The Silk Road encouraged the travel of art, religion, cultural elements. The swift expansion of the Mongolian empire with the Mongols appearing at the eastern borders of Germany as well as in Korea, India, China, Persia and nearly all over the Eurasian continent showed that Central Asia had no borders for the nomads. But the Mongols beyond the Central Asian steppes lost their identity soon. The natural environment and the national and ethnic identity exist in a symbiosis. The harsh natural environment of desert, steppe, tundra and taiga form the people living there in a distinctive way, different from that in China, India or large parts of Europe that lie in the agricultural belt.

Politically the empires of the steppes were short lived in comparison to the neighboring Chinese or Byzantine empires. The empire of the Tujüe, building on that of the Rouran and Hsien-pi, is destroyed by the empire of the Uyghur, which again is followed by that of the Kirghiz and later by the Khitan and Mongolian empires. Despite the changes in power there is no vacuum but a certain continuum of steppe empires which is only broken by the encroachment on Central Asia by the Russian and Chinese empires mainly from the $17^{\text {th }}$ century onward.

Most of the indigenous peoples of Central Asia belong to the Altaic group, originally defined by languages that are related to each other within the Altaic language group, including all Mongolian, Turkic, Tungus-Manchu languages. On the southern fringe of Central Asia, especially Tajikistan and parts of Afghanistan Indo-Iranian languages prevail, and if you include Tibet you enter the Sino-Tibetan group of languages. But over $90 \%$ of Central Asia is dominated by Altaic speaking peoples. Through its language each nation defines its own identity in the first place. $^{7}$

To understand the peoples of Central Asia nothing is better than learning their languages. As Turkic and Mongolian and Tungus-Manchurian Peoples dominated and shaped the history of Central Asia over so many centuries they left a wealth of written documents that form the basis of Central Asian studies. A few years ago in China the entire Manchu archives for Xinjiang in 283 facsimile volumes were published. ${ }^{8}$ Equally large collections of Manchu archives are published for Manchuria

\footnotetext{
${ }^{7}$ Lenk, Uschi; "Sprache ist die Identität eines Volkes" (Svetlana Cholutaeva - eine kalmückische Doktorandin); In: Uni Journal der Universität Jena, 2007-9. http://www.uni-jena.de/uni_journal _07_2009_Portrait.html

${ }^{8}$ Qingdai Xinjiang manwen dang'an hui bian 清代新疆满文档案汇编, Guilin 2012 (shelfmark SUB Göttingen: 2013 B 461: 1-263).

A similar facsimile edition has been published for the area of the commandery of Hunchun covering northeastern Manchuria: Hunchun (Huichun) fudutong yamen dang 琿春副都統衙門檔 (shelf mark 2010 B 291: 1-238). This collection also contains Chinese and even Russian material for the later
} 
and China proper. And in Inner Mongolia similar editions of Mongolian archive Material are published. ${ }^{9}$ These published Manchu and Mongol archives are a treasure trove for any linguist, historian or anthropologist in the widest sense.

To understand the difficult situation in Sinkiang and also Inner Mongolia, today in a modern multi-ethnic state like China, one has to go back to the roots of today's troubles. There is the Ili-crisis in the 1860s and 70s, when Russia occupied part of Sinkiang, there are the Dzungarian wars of the Manchu-Chinese emperor Ch'ien-lung in the 1750s against the Western Mongolian Oirats in Sinkiang. The modern name Sinkiang, meaning New Territory stems from the time when in 1757 the Manchu conquered that area from the Mongols who had ruled it for centuries. And when we go back further into the history of Sinkiang we will find other peoples of Indo-Iranian tongues settling in that area and so many documents in ancient languages preserved in the dry desert climate.

Not only China, but also Russia is a multi-ethnic state. Kalmykia or Buryatia are republics within Russia with large archives, holding Mongolian and other material. ${ }^{10}$

But of course only a small part of historical material has been published. Much remains locked up in museums and archives. Some of these archives and oriental collections are accessible for scholars who undertake the long journey to view them. But often enough even the knowledge about these collections is not very wide spread. No network connects the thousand and more places where material

years of the Qing Dynasty. The complete Manchu Kanjur in 109 boxes as a handmade print from the original woodblocks from 1790 is available under the shelf mark A 2010 B 35001: 1-109 at SUB Göttingen.

After the fall of the Qing dynasty 1911/12 the use of the Manchu language declined fast. Today Manchu is actively only used amongst the Sibo in Ili and Sinkiang in general. In Göttingen you can find the twice-weekly Manchu language newspaper from Chabchal/Ili, the Cabcal serkin, since 1980 (shelf mark ZTG B 238) with a few earlier volumes of the Ice Banjin from the 1950s. The Göttingen State and University Library (SUB Göttingen) has the largest collection of Sibe material in Germany. All literature in Manchu and Sibe available at SUB Göttingen can be found by inserting "spr mnc" into the searchslot at www.sub.uni-goettingen.de.

${ }^{9}$ Daičing ulus-un mayad qoli; Hailar 1990-1992 (shelf mark FB 28606: 1-22) (Mongolian Veritable Records of the Qing-Dynasty. 22 vols.)

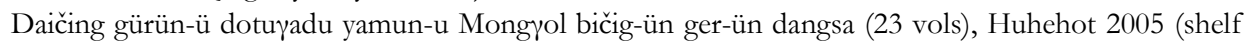
mark 2006 B 1598:1-23) (A facsimile edition of letters and documents from the "Neige", the imperial secretariat responsible dealing with the Mongols, Tibetans, Hui (mainly Muslims from Sinkiang) from the years 1671 to 1743 . The first 14 fascicles for 1671 to 1687 are mainly in Mongolian, rarely in Manchurian. Manchurian documents increase in number for later years. For the last years of this period there also appear some Tibetan documents. The Index-Volume in Mongolian-Manchurian script provides some details as to the language of each document.)

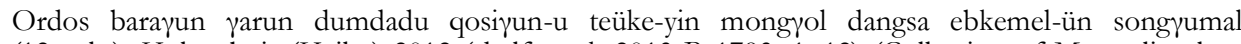
(12 vols.); Hulun buir (Hailar) 2012 (shelf mark 2013 B 1793: 1-12) (Collection of Mongolian language archive material from the Righthand Wing of the Middle Banner of Ordos)

Literature in Mongolian (from Inner and Outer Mongolia) available at the Göttingen State and University Library can be found by inserting "spr mon" into the searchslot at www.sub.unigoettingen.de. Or insert "spr bua" for Buryat and "spr xal" for Kalmyk literature. Göttingen has the largest collection of Mongolian literature anywhere in Germany.

${ }^{10}$ See the article in this volume by Surun Syrtypova on archives in Buryatia. 
for the research on Central Asia is stored. This conference is another step towards making the most famous Oriental collections, be it in St.Petersburg, in Huhehot, Szeged, Berlin, Prague, Warsaw and many other places better known to more scholars. The ultimate goal should and would be, to have the links towards the websites of all collections collected on one central website, to be able to go to the online catalogues of each collection and from there on find every item, every manuscript or print available freely in digitized form from where ever you are. We can only make small steps into the right direction, but as can be seen in the publication of so much archive material in China over the past few years, things are moving.

Talking about the drive towards digitization one cannot fail to recognize that still in most cases valuable archive material is issued in facsimilized printed volumes on paper rather than online. Online often seems more convenient, but then, online means that digitized material is made available from a server housed somewhere in Central or East Asia maybe in a politically instable region. Will it be online for long? Or may it be manipulated? This same problem of course applies to modern e-books and journals that may be available online from Central Asian countries. But can you rely on such online material in the long term? Is it justified to pay for the convenience of this moment without regard for future generations of scholars? These are hotly debated issues in the world of libraries today.

To understand modern Sinkiang or Inner Mongolia, Manchuria and other Central Asian regions, one has to go back to the archives and the material preserved there.

In the good old days every Sinologue had to study not only the classical Chinese language but most scholars in East Asian studies had at least a basic knowledge of Manchu and Mongolian. In these even better and unsurpassed modern times hardly any sinologist studies Manchu or Mongolian. And how many students in the field of Turkic studies learn the Chagatai written language, once the lingua franca of Central Asia? But who of these modern scholars is going to understand modern Sinkiang, modern Uzbekistan, Kazakhstan, Mongolia and so on without being able to study the old texts as well as modern literature, that often quotes the older sources in the original languages?

As my most honoured teacher Prof. Gerhard Doerfer used to say, pure linguistics is poor linguistics. But anyone talking of Central Asia, modern or ancient, without any philological knowledge of the languages of Central Asia will be worse off than a pure linguist, he will be just helplessly groping and stumbling in the fog.

We have mentioned earlier the modern drive towards digitization and online material. But of course you can only digitize material which is already available in printed form on paper or as manuscript. So you do not get any new information by digitizing. It is just a matter of convenience.

On the other hand, so much information nowadays is found only virtually on the World Wide Web on email servers, in chatrooms, private blogs or government websites and so on. Often it is short lived and disappears unretrievably. In 2013 Vint Cerf, a "father of the internet" and a Google vice-president, said he is worried 
that all the images and documents we have been saving on computers will eventually be lost. "Our era could soon become the Digital Dark Age."11 Cerf's main concern was the medium, be it floppy disk, CD, USB stick or other on which information is stored. You may put a printed book onto the shelf for a hundred years and forget it. It will still be there a hundred years later. Not so the data stored on electronic devices. They have to be restored on new devices every ten or so years putting a great burden on libraries. And even then a certain percentage of electronic storage devices do not even survive ten years.

But much of the information to be found on the internet is never stored properly in the first place.

The whole development of youth language, substandard language, internet slang with its constant fast changes can only be followed in chatrooms or emails that are never saved for any considerable length of time. In 50 years' time we might wonder how young people communicated in 2014.12 Also, many governmental and non-governmental organisations issue material only online. This includes e. g. the Ministry of Education in Mongolia, issuing the latest school books on their website. It also includes local information issued and constantly updated and eventually deleted by local government or private organizations in Mongolia or elsewhere. ${ }^{13}$

Archiving rare language material is done in several independent projects. Here the problem of a lack of coordination and limited funding for each project is obvious. One such project is found at the Max Planck Institute for Psycholinguistics ("The Language Archive") in Nijmegen in the Netherlands. ${ }^{14}$ There are also attempts to save some of the language material in the archive "ELAR" at the School of Oriental and African Studies in London, which is password protected. ${ }^{15}$ This reminds us of the thorny issue of copyright laws that prevent us from saving all this valuable information available only on the internet and may lead us into the real Dark Ages.

The so called "Internet Archive" under https://archive.org/ is based in the United States of America and operates in a legally grey area of fair use agreements

\footnotetext{
11 http://www.npr.org/sections/thetwo-way/2015/02/13/386000092/internet-pioneer-warns-ourera-could-become-the-digital-dark-ages

12 There are attempts to collect some Kalmyk data from Twitter: http://indigenoustweets.com/xal/, http://www.language-archives.org/language/xal

13 There are a few Mongolian educational websites. They are updated and changed regularly. I am thankful for the valuable hints Atilla Rákos from Eötvös Loránd University, Department of Mongol and Inner Asian Studies, Budapest, who also participated in this conference, gave me on this matter: Mongolian ministry of education (schoolbooks etc.): http://www.meds.gov.mn/wbooks $/ 1 / 5$; Öwörkhangai's Provincial Office of Education and Culture: http://uvbsg.blog.gogo.mn/read/ entry325591; "A computer for every child" (Mongolia): http://laptop.gov.mn/index.php? option $=$ com_content\&view $=$ category\&layout $=$ blog $\&$ id $=45 \&$ Itemid $=43$

14 https://tla.mpi.nl/resources/data-archive/

15 http://elar.soas.ac.uk/deposit/0310
} 
that may be challenged. ${ }^{16}$ It attempts to harvest as many websites as possible in regular intervals. The large intervals are of course a problem if you want to document an ongoing exchange on Twitter or any other chatroom elsewhere. It archives the picture of a certain website at a certain moment. It does not harvest the material the links on websites lead us to. It does not offer any in depth intellectual classification of the material it sends into the archive. But it offers a certain basis on which it may be worth working on.

A new development makes writing in the internet less attractive to many: Store your spoken message like an email that can be read or rather heard by the other side at any convenient moment. Chats with endless emoticons or short forms like LOL for "Laughing out loud" and all the rest of internet slang may be a thing of the past soon - of an unretrievable past.

The future may be digital. But the present may be the lost past of generations to come.

\footnotetext{
${ }^{16}$ Lila Bailey; The Copyright Office is trying to redefine libraries, but libraries don't want it - Who is it for? https://blog.archive.org/2016/07/27/the-copyright-office-is-trying-to-redefine-libraries-butlibraries-dont-want-it-who-is-it-for/
} 



\section{A preliminary survey of the keyimori in Ordos}

Ayalagu (Minzu University of China, Beijing/Charles University, Prague Masaryle University, Brno)

\section{Introduction}

Almost every Ordos Mongolian family, especially those who live in the traditional way as nomadic or half-settled herders, hang a small flag, known as "keyimor" (wind horse) in Mongolian and "rlung rta" (wind horse) in Tibetan, outside their houses or yurts. These prayer flags are also used as offerings at sacred sites and shrines.

Although the phenomenon of the "wind horse" (keyimori) is well known from Tibet, its origin is still unclear, and some theories link it to the influence of the Mongols. For centuries, people in both Tibet and Mongolia have been have placing these "wind horses" (keyimori) outside their homes and sacred sites located outdoors in the belief that the wind horse would carry the beneficent vibrations across the countryside. In the folk belief, the "wind horse" (keyimori) is said to bring happiness and long life to all beings in the vicinity. Although the practice of hanging keyimori has spread across the whole area of greater Tibet and Mongolia, in Ordos some specific features unique to this area are worthy of mention. 


\section{Sections and paragraphs}

\subsection{The origin of keyimori}

The Mongolian term keyimori has been noted in at least three known versions; for example "kiimori, kiimar, kiyamar" and so on. In earlier days, it was written as two words: kei-mori. The term keyimori came into wide use in the 19th century. ${ }^{1}$

In Ordos Mongolian, the formulation kei mori implies good luck for the human body. In Ordos Mongolian people hang the small flag ' kei mori' in front of the yurt or house. ${ }^{2}$

As for the oldest Mongolian talkative dictionaries, no explanation for the word keyimori is provided in the "Dictionary in 21 volumes" (composed in 1743, edited in 1979), but the sixteenth day of the first month of the lunar calendar is the day of thriving (flourishing, developing) keyimori. ${ }^{3}$ The sixteenth of first month is a day of the thriving keyimori also according the Šayja's "Mongolian explanation dictionary" of 1926-1929.4

According to the "Dictionary of Ordos dialect", keyimori means good luck or a small flag. ${ }^{5}$

In the "Tibetan Mongolian Chinese dictionary", Keyimori is rung rta, yunqi 运气, thriving keyimori means good luck, zouyun 走运, declining keyimori signifies bad luck 倒霉. ${ }^{6}$

According the "Mongolian English Chinese dictionary", keyimori: fortune, luck, yunqi 运气, keyimori kebtekü: have bad luck, daomei 倒霉.7

According to the "General Dictionary of Monglian customs", Keyimori, or "wind horse", means a small flag usually surmounted by a trident showing the imprint of the "jewel-bearing horse" (erdeni mori) and tarni: a symbol procuring good luck. Kei moritai-lucky, fortune. ${ }^{8}$

\footnotetext{
${ }^{1}$ Information communicated by Prof. J. Lubsangdorji, personal interview, Prague, 31th March 2015. Prof. J. Lubsangdorji is Associate professor at the Department of the South and Central Asia, Faculty of Arts, Charles University in Prague, and a leading Mongolian linguist with a broad knowledge from oral traditions of Mongolian nomads.

${ }^{2}$ Buyanwčir, personal interview, Kiy-a baysi toyurig, Ordus qota, 5th April 2015.

${ }^{3}$ Qorin nigetü tayilburi toli 1979, Öbür mongyol-un arad-un keblel-ün qoriy-a, Kökeqota, p. 341.

4 Šayja 1994, Mongyol ügen-ü tayilburi toli. Dumdadu ulus-un ündüsüten-ü keblel-ün qoriy-a, Begejing, p. 370.

${ }^{5}$ Sonum 2008, Ordus aman ayalyun-u üges-ün quriyangyui. Nemen jasaysan debter. Öbür mongyol-un arad-un keblel-ün qoriy-a, Kökeqota, pp. 203-206.

${ }^{6}$ Temürčidür - Cangjoriy 2001, Töbed mongyol kitad qaričayuluysan yeke toli. Liyooning-un ündüsüten-ü keblel-ün qoriy-a, Šenyang, p. 1595.

7 Sodubilig 2006, Mongyol anggli kitad toli. Öbür mongyol-un suryan kümüjil-ün keblel-ün qoriy-a, Kökeqota, p. 354.

8 Bürintegüs 1999, Mongyol jang üile-yin nebterkei toli. Öbür mongyol-un sinjilekü uqayan-u teknig mergejil-ün keblel-ün qoriy-a, Kökeqota, p. 255.
} 
Two divergent explanations of the word keyimori are provided by the lattermentioned dictionary. One is the profane meaning, reflecting the word's understanding among the common people, and the other is the sacred meaning (among the clergy). In this case, the popular explanation adds the specific visual trait, i. e. color, to the religious explanation and then applies the term to the flag, the banner of the wind. The ethnic Mongolians of Ordos hung the small flag in front of the yurt, which distinguished a Mongolian family from a Chinese family.

According to the common Ordos concept, the Mongolian keyimori represents the hitching post column for Chinggis Khaan's sacred white horse and eight light bay horses. To express the horse's hitching post column, a supernatural column is evoked through the Mongolian practice of raising this small flag every day. This practice is also a sign of the Mongolian people's love for the horse. In consequence, Mongolians traditionally respect a raised keyimori, and a raised keyimori in turn expresses good luck for every day to come in the future. ${ }^{9}$

To summarize, Mongolian people express their love for the horse through absorbing its spirit in the keyimori. The keyimori, as a result, is represented by the daríng (small flag) which is used attached to a horse's mane.

\subsection{The offering of the Ordos keyimori}

Ordos Mongolians raise the keyimori every day. If any person fails to make the offering of the keyimori, this person is regarded as an "extinguished hearth" ( $\mathrm{a}$ al yolumta tasuraqu), or one to receive misfortune in life (yai jobalang tayariqu). In the offering of the keyimori, a small box with sang (incense offering) is placed in front of the keyimori at the time of the raising of a lay person's keyimori.

Ordos Mongolian people construct the keyimori platform (keyimori-yin bayan-a „keyimori column", keyimori-yin sörü „,keyimori altar", originally in the form of mound or trellis) in front of the yurt or house. At the top of the column, there is a qara sülde ("black standard"), which originally referred to the mane of a horse, though wood or sheep wool are also used to connect the two columns. Small blue, red, white, yellow and green flags are also hung at the keyimori. A full keyimori contains the platform, column, flag, keyimori-yin kökül (horse's mane), pitchfork, bayan-a (column), prayer flags (dalbay-a, darčng), tayiz (cane), kele (,tongue“), jele (rope with tethers), sang-un sörü and other components. (Figure 1)

\footnotetext{
9 Sungdui, Ögeled Qoyid 2003, Jiruqai. Öbür mongyol-un suryan kümüjil-ün keblel-ün qoriy-a, Kökeqota, p. 276.
} 

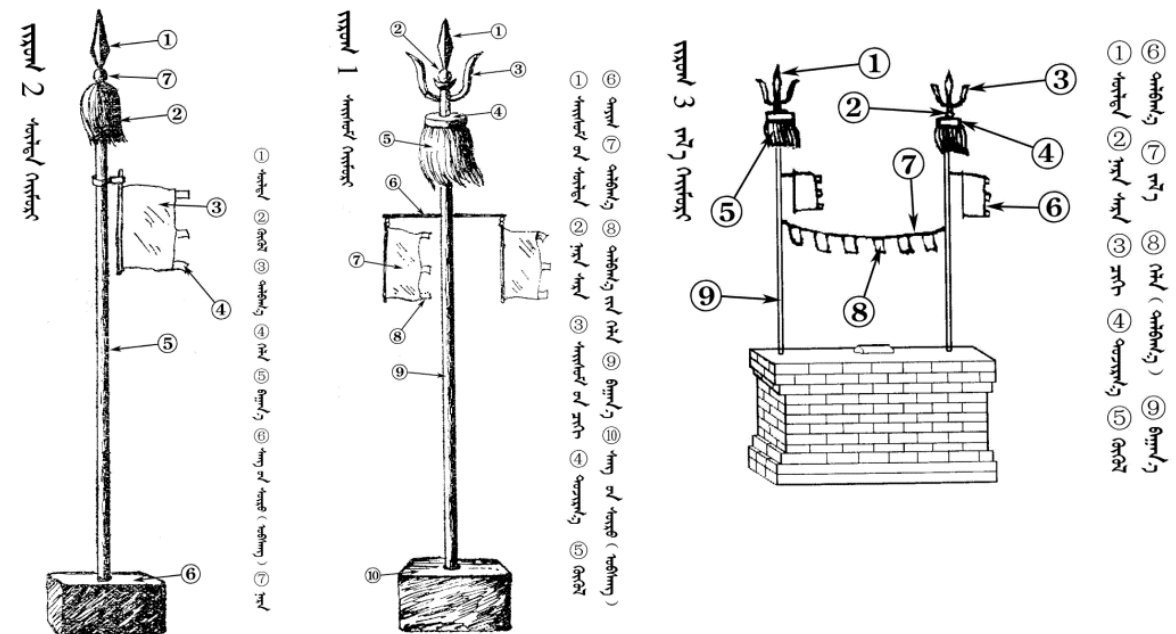

Figure 1: Various types of Ordos keyimori

(on the left) Sülde keyimori (Keyimori of Süld): 1. sülde (Süld, "soul”), 2. kökül (horse mane), 3. dalbay-a (prayer flag), 4. kele ("tongue"), 5. bayan-a ("column, pillar"), 6. sang-un sörü (ubsang) (offering's altar), 7. nara ("sun")

(in the middle) Seyisüm keyimori ("Trident keyimori"): 1. seyisüm-ün sülde (Süld/soul of the trident), 2. nara sara ("sun and moon"), 3. seyisüm-ün cikiki ("ears of trident"), 4. tujiry-a (also tujary-a, bowl), 5. kökül (horse mane), 6. tayij (cane), 7. dalbay-a (prayer flag), 8. dalbay-a-yin kele ("tongue" of the prayer flag), 9. bayan-a ("column, pillar"), 10. sang-un sörü (ubsang) (keyimori altar)

(on the right) Jel-e keyimori (Keyimori with a rope): 1. sülde (Süld, "soul"), 2. nara sara ("sun and moon"), 3. čiki ("ears"), 4. tujiry-a (bowl), 5. kökül (horse mane), 6. dalbay-a (prayer flag), 7. jel-e (rope with tethers), 8. kele (dalbay-a) ("tongue" = small prayer flags), 9. bayan-a ("column, pillar")

\subsubsection{The color of the darčug with the keyimori}

The darcugs accompanying the keyimori contain the darčng and the keyimori's tongue. This small flag was transmitted from Chinggis Khaan. To cite Če. Damdinsürüng (Ц. АамАинсүрэн): "If there arises a bad time of suffering, we tribal-lineage Mongolians, building our white yurts on the wide pastures of our homeland, causing our country to blossom, waiting for our voice, whereto came rising the very first picture of the hero on horseback on the peak of the mountain, on the ovoo of the sülde of the nation, and on the top of the majestic tree. If one is to look at the origin of the picture on the sacred keyimori, placed outside of the ger, of the steed, playfully arising, known honorifically as 'aryamay', it is a fighting horse ready for battle-where is our hero? ask the weary Mongolians, wishing to cause their keyimor to be a flame; kei is the depiction of a horse fast like the wind, and so it is called, like the wind of the steppes playfully arising. Thus causing the powerful nation to 
flourish, symbolizing the non-birth, the absence, of the lord and hero, is the horse, with bridle and saddle; its beautiful peaceful back, instead of a manly hero (riding it), it is packed with jewels." 10

From his explanation, we find that the keyimori has blue flags for Mongolia, red for China, yellow for sartayul (Muslims of Central Asia), white for Korea and black for Tibet (tabun öngge dörben qari „five colors, four alien peoples“), all of which used to be intergrated in the Mongol Empire.

Previously, in Mongolian territories, people hung only a small blue flag, because blue symbolizes the sky and Mongolia. Every nationality appreciates the colors that are related to Mongolian history and life.

In ancient times, the Mongolians respected the color white, which is a legacy from shamanism: out of respect for heaven, the Mongolians make a libation of kumis to Heaven.

The ancient Mongolian practice was to hang only these two colours - blue and white - as flags. Following the spreading of Buddhism to Mongolia, flags of red, yellow and green colors were added, so that from this time onward, Mongolians have raised five differently colored flags. Blue symbolizes the sky and heaven, white symbolizes mothers' milk, red symbolizes the blood of an animal, yellow symbolizes the dust of the world, and green symbolizes all-constituting qan delekei (a widely understood concept of a highest deity similar to the deified heaven). ${ }^{11}$ During field research that I conducted in Ordos in the summer, I found that one lama family raised a black prayer flag, though not throughout the year: it was only raised from the first month to the fifth month, and only in this lama family. ${ }^{12}$ Traditionally, Mongolian prayer flags come in sets of five, one in each of the five colors, which are arranged from right to left in a specific order: blue, red, white, yellow and green. If every person worships the keyimori, that person acquires good fortune. In addition, Mongolian people said that yellow symbolizes the land, while the green, white and red colors symbolize the grassland, the flock of sheep, flowers respectively: blue (heaven), white (mood/heart), red (animals), yellow (land) and green (plants).

Regarding the materials used by Mongolians for making keyimori, two types are known: the cloth keyimori and the paper keyimori. The block-print keyimori are the ones previously discussed which are used for worship on a daily basis. As for the paper keyimori, these are thrown to the wind from a high place on the first tiger day of the tiger month. The higher the wind, the higher the flight of the paper keyimori, and this is seen as bringing good luck and good fortune. To throw the paper keyimori on that specific day signifies that those who do so will have the fortune of the

\footnotetext{
${ }^{10}$ Quoted according to Namjildorji 1992, Ordus jang üile-yin tobči. Öbür mongyol-un soyul-un keblelün qoriy-a, Qayilar, p. 391.

11 Bürintegüs 1999, Mongyol jang üileyin nebterkei toli. Öbür mongyol-un sinjilekü uqayan-u teknig mergejil-ün keblel-ün qoriy-a, Kökeqota, p. 255.

12 Jiryal, personal interview, Üüsin qosiyu, Ordus qota, 6th September 2014.
} 
tiger throughout the year. Moreover, all Mongolians remember that Chinggis Khaan ascended to the throne in a red tiger year (1206).

In general daily practice, Mongolian men are the ones to burn incense, making an offering of incense every morning. For the offering, the juniper, sandalwood, and incense are burned, along with the sacrifice of the first serving of food and drink and the blowing of a conch. No less important is the dispersion of milk tea: the scattering or pouring of milk or tea for the deities; or of grain and food scattered as offerings to deities to call the heaven.

At this moment, the man recites "keyimori-yin sang", "ejen-ü sang", "sülde-yin sang" and other prayer texts. In order to ensure all people good luck, it is also necessary to make a full prostration of oneself before the wind horse after it has turned around three times.

\subsubsection{The keyimori as block-print or xylograph (on paper or linen)}

In general, the keyimori block-print iconography displays the figure of a horse in the middle, which is entirely surrounded by writing in Tibetan and Sanskrit, this text being known as the "small printing". Nowadays, many different types of blockprints are used among the Ordos Mongolians. Here, the very largest such print contains figures of the sun, moon, horse, dragon, garuda, tiger, snow lion, the twelve animals of the Eastern zodiac, twenty-eight stars, also known as the Four Dignities, adorn each corner of the flag: these are the dragon, the garuda (a mythological bird, often seen as a messenger from the gods), the tiger, and the snow lion.

I have collected images of many different block-prints from Ordos and Xinjiang, which I would now like to describe and explicate in detail.

(1) The first wood-block print is from Xinjiang, and shows a horse in the middle of the cloth, with four animals in the four corners and eight offerings on the two sides. Many Tibetan words and mantras are written in the middle, the meaning of which is to eight offerings, and nine birthmark mengge (wrathful deity, Tibetan 'sme brtsegs') all displayed on the block-print. Images or names of four powerful animals, wish all people good luck and success in life. It is confirmed, that this print has been given in 1675 by the Fifth Dalai Lama Ngawang Lobsang Gyatso to Očirtu Sečen qayan. ${ }^{13}$ (Figure 2)

\footnotetext{
${ }_{13}$ Dosan - Önir 2012: 282-290. The original block-print is kept by Übüljing genggei (lama) in Tekes siyan, Xinjiang.
} 


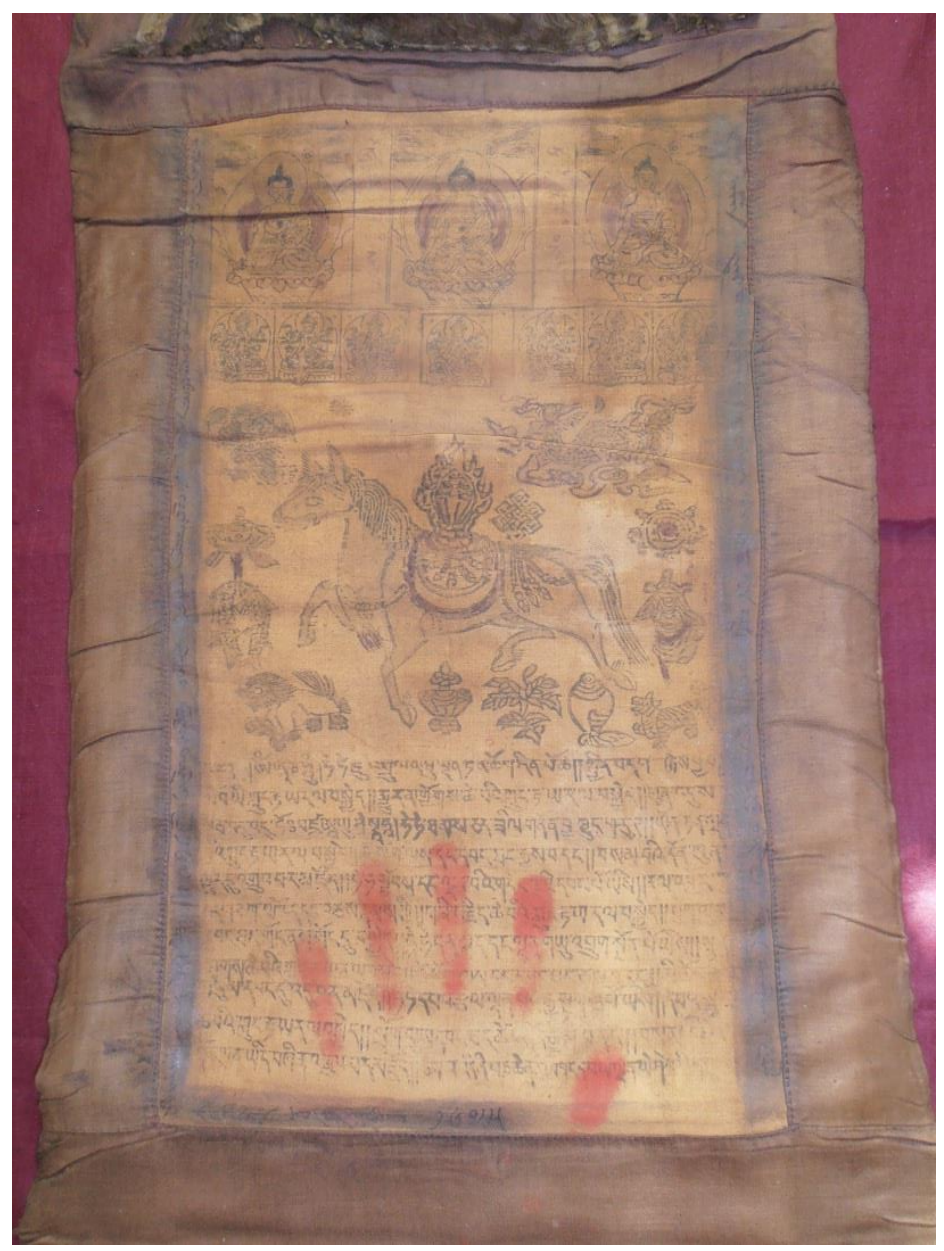

Figure 2: Keyimori stored in private home by lama Übüljing genggei and Ja. Dosan in Tekes siyan, Xinjiang 
(2) The most notable difference in this modern print from the previous one is the presence of a Mongolian Soyombo symbol of a Mongolian flag at the top. However, the remaining iconography is the same as in the previous figure. (Figure 3)

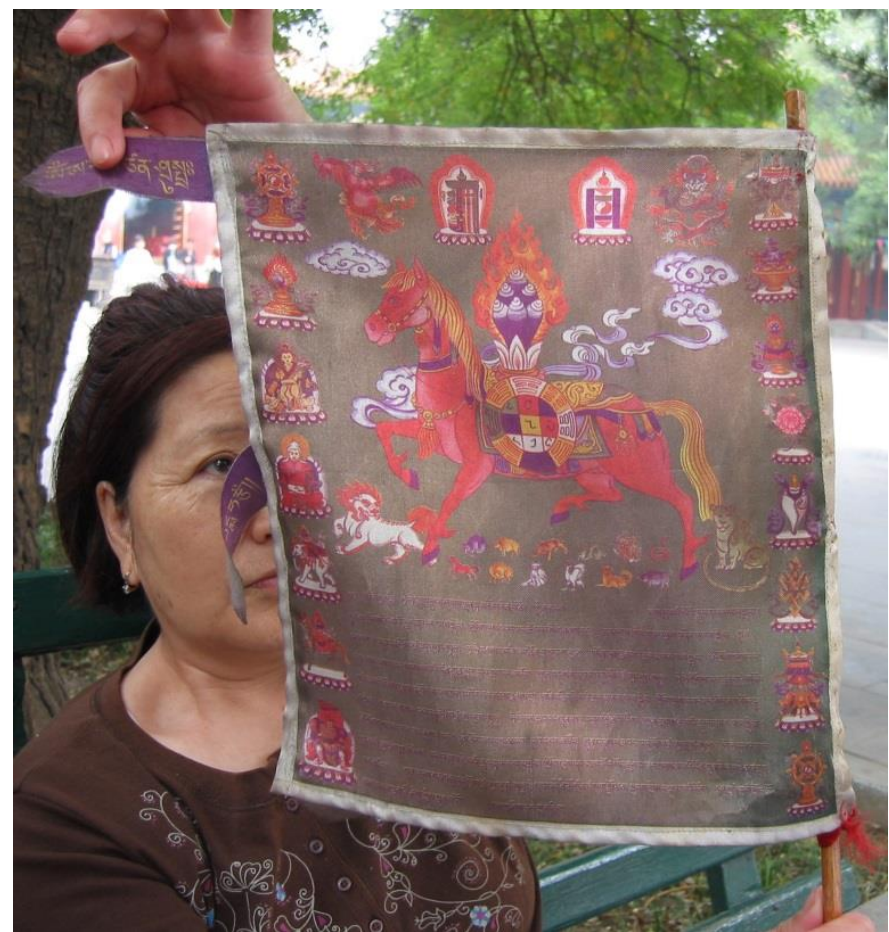

Figure 3: Modern Keyimori print. Kökenayur (Qinghai) 
(3) The block-print printed on silk

An image of fire is shown at the top of the silk print, and the figure of Maqayala is situated in the middle. Surrounding these images are the Tibetan words "aom hav kav li mo ha ha ye srav hav vdiv thar bsol", around which are the names of twelve significant animals in Tibetan. (Figure 4)

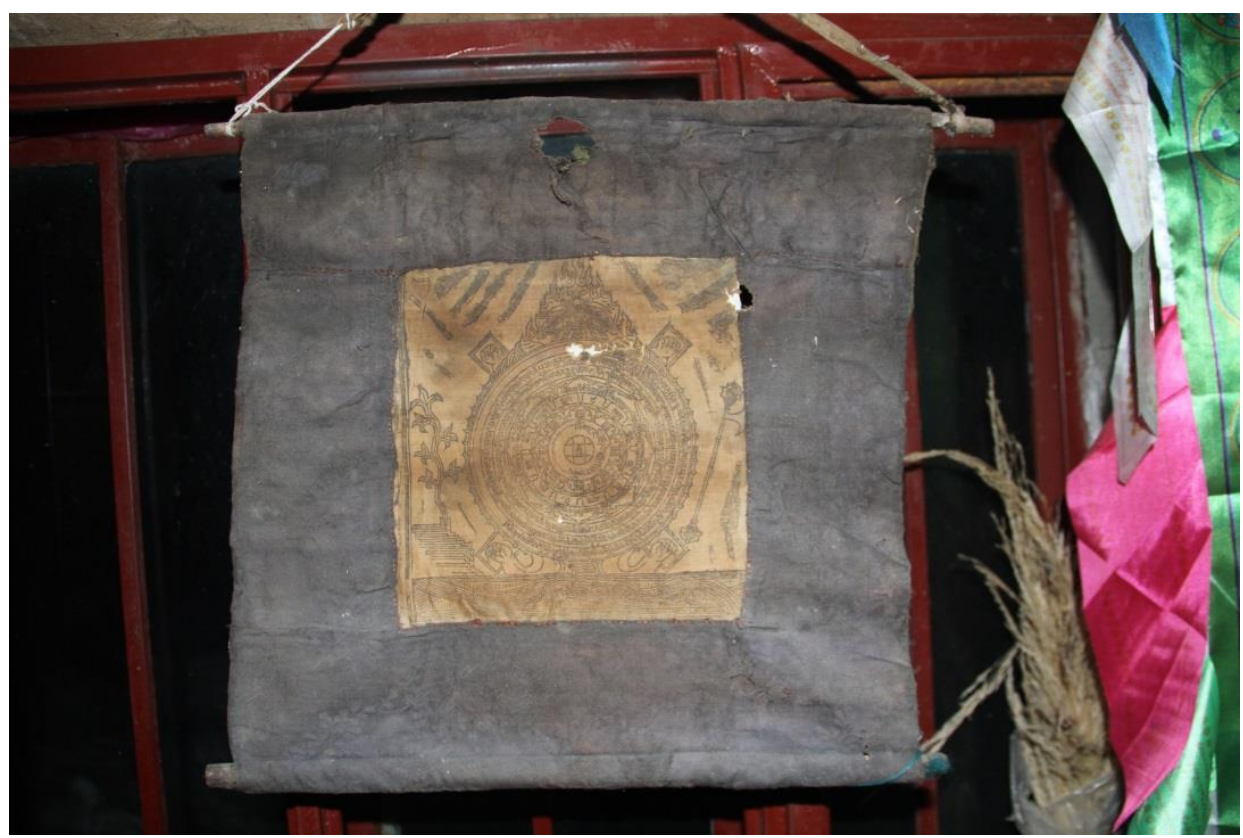

Figure 4: Tekes siyan, Xinjiang 
(4) In this example, a man is shown riding on the horse, while the surroundings of the central image contain three Tibetan wild animals (Mi-thun-gyul-rgyalgsum): the eight-footed male tiger (Seng-ge-rkang-pa-brgyad-pa) on the left, the seashell (Chu-sring) on the right, and below is an otter (Nya-spu-rgyas-pa). Above the figure of the mounted hero are figures of the sun, moon and sülde, along with many words in Tibetan. (Figure 5)

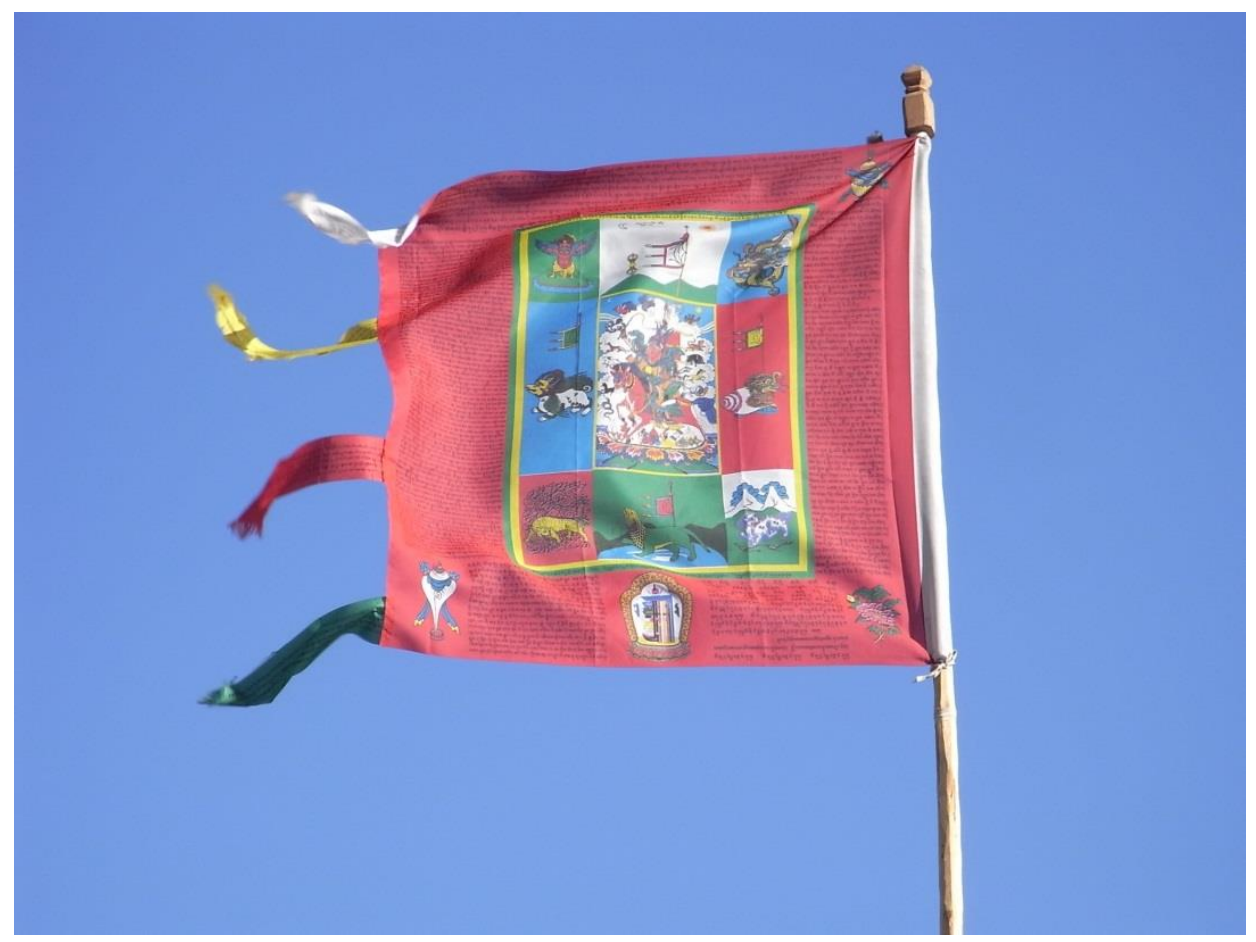

Figure 5: Modern Keyimori print. Jo Khang Monastery, Lhasa

To summarize, the Xinjiang double print is of very ancient origin, while the other examples are much more recent. What is common to these block-prints is the figure of a horse, four Tibetan animals and many Tibetan words and mantras, wishing all people good luck, hope for rain, appeals for health and long life and other similar sentiments. Therefore, the words, mantras and picture on the darćng have a strong iconographic and semantic connection with each other. The offering of the keyimori (keyimori-yin sang) represents the ceremony attaching importance to the four animals and to the natural and human worlds. The physical prayer flag (keyimori-yin darcug) forms a different side to the keyimori-yin sang, invoking the presence of visual images: the twelve animals, the seven jewels, the eight offerings, the three Tibetan wild animals and the other common figures. As a result, the keyimori-yin darčng and the keyimori-yin sang express complementary relations and differences. 


\subsection{The offering (sang) of the keyimori (keyimori-yin sang)}

Standard religious practice among Ordos Mongolians is for the man to make an offering of the keyimori every morning and then to read the offering texts, variously known as the "keyimori-yin sang", "ejen-ü sang", "sülde-yin sang" or other terms. Most often invoked by Ordos Mongolians are the keyimori and sülde (var. sülide) sangs, which are commonly treated with great respect. In Ordos, riders on horseback avoid passing through the inside of the keyimori. In the event of the death of an older person, the post to which the "wind horse" (keyimori, kei mori) is attached is lowered for a period of 7 or 21 days, with the left-hand post is lowered to rest on the platform. Another custom is to change the block-print prayer flag (dař́ng) every New Year, or on certain special occasions, such as the birth of a son or a wedding ceremony.

\subsubsection{The origin of the keyimori offering (keyimori-yin sang)}

By itself, the word sang refers to the burning of incense, which is an extremely widespread custom. Mongolians burn incense as an offering performed to hills, water, rivers, or ovoos(Obos, heaps of stones often acting as places of worship on hilltops or mountain passes), as well as making the offering of juniper, sandalwood, and incense to the ancestors. Since the Mongolian word 'sang' is derived from the Tibetan word bsang, it has various pronunciations and orthographical varieties in Mongolian (sang, bsang, basang, obsang). On the one hand, the poetry associated with the ceremony of sang contains elements from shamanism and Buddhism. ${ }^{14}$

On the other hand, sang is also etymologically linked to the Mongolian word sangyilaqu (to burn incense; for example, jagar-un ünür sangyilaqu, em-ün ünür sang gek.iu). ${ }^{14}$ Hence the Tibetan bsang and the Mongolian sang are linguistically as well as historically connected with each other, evoked in the daily Mongolian practice of the burning of incense.

The keyimori-yin sang is the poetry recited during the Mongolian offering. The keyimori-yin sang addresses both nature (prayers to nature for favorable weather, etc.) and people (e. g., health of both humans and livestock, etc.).

I have collected 16 Mongolian texts of keyimori-yin sang along with a number of texts in Tibetan. One of these is the keyimori-yin sang edited by Urad-un Mergen Gegen Lubsangdambijalsan which is a comparatively early text (18 $8^{\text {th }}$ century), created during the period of the first spread of the practice of the keyimori-yin sang to Ordos and Bayannayur, among other localities (TEXT A, see Figure 6).

14 Kesigtoytaqu, Č. 1998, Mongyol-un erten-ü udq-a jokiyal-un sin-e sudulul. Öbür mongyol-un arad-un keblel-ün qoriy-a, Kökeqota, p. 152. 


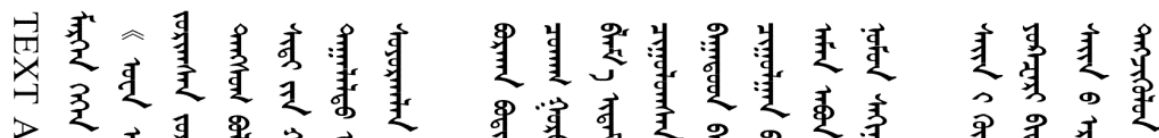

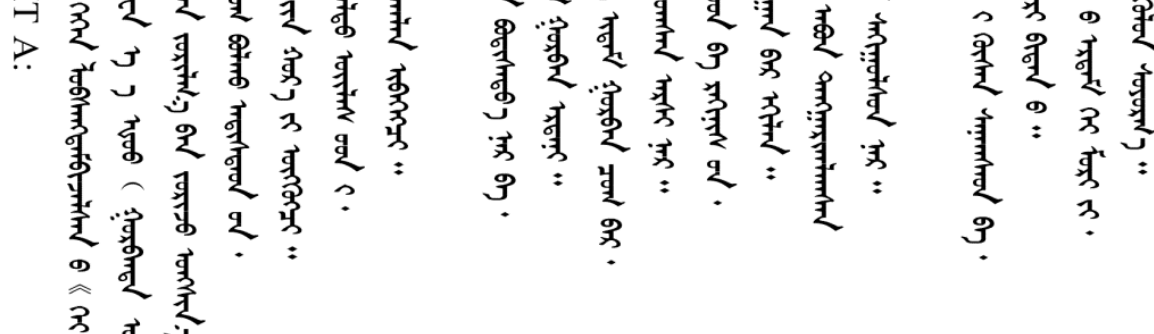

放 桴

त्रे

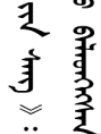

亦

2

न

是

是

궁

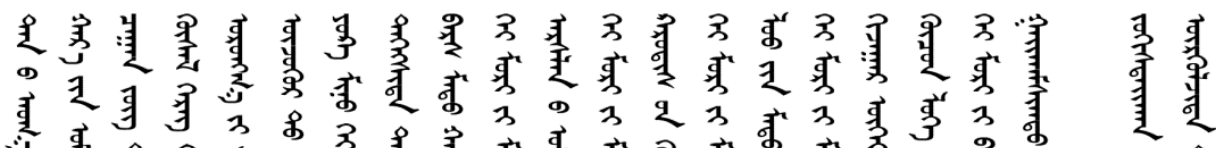

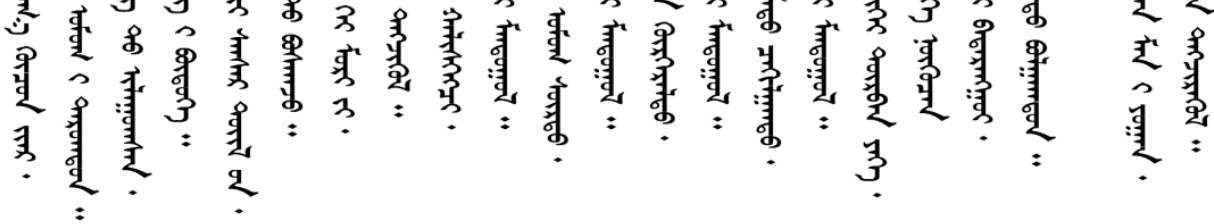

Figure 6: Texts A to E 


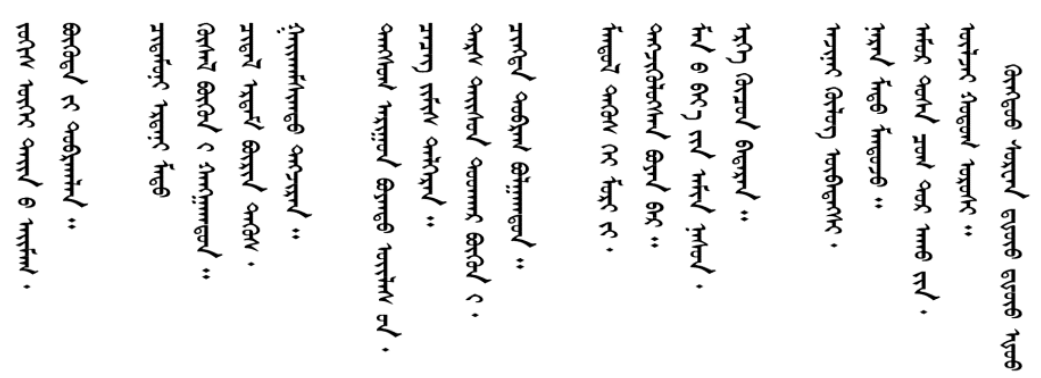

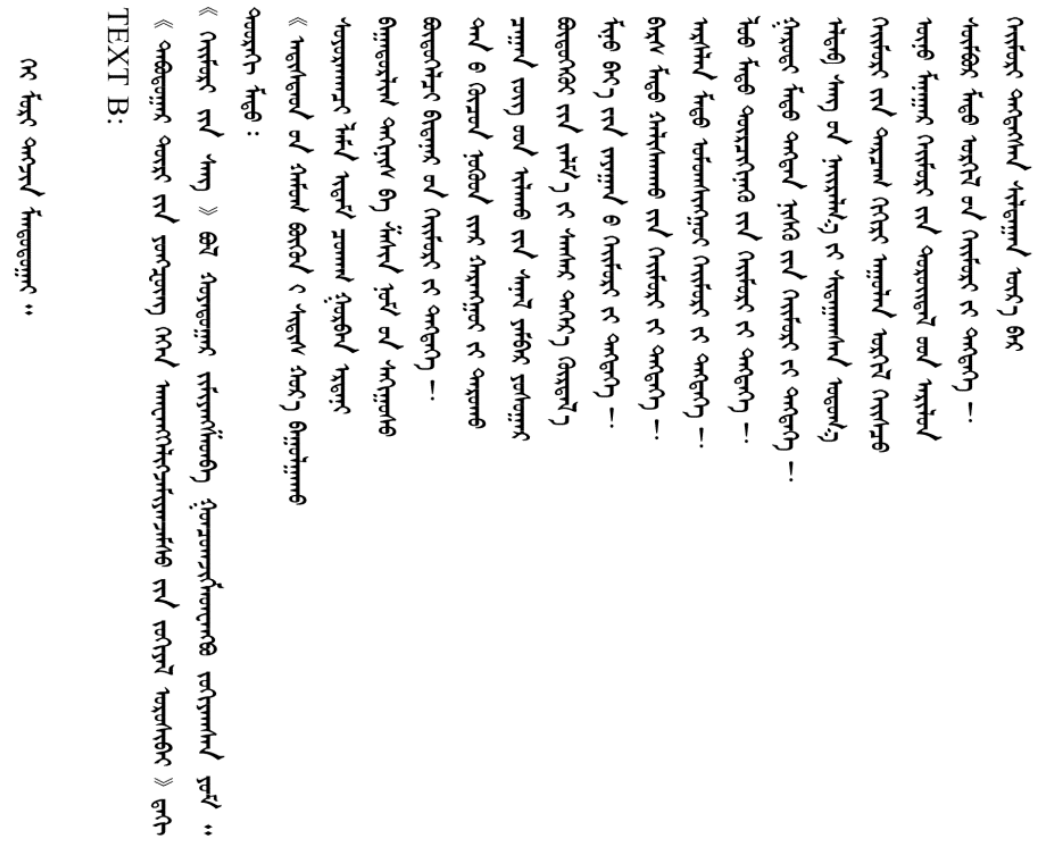




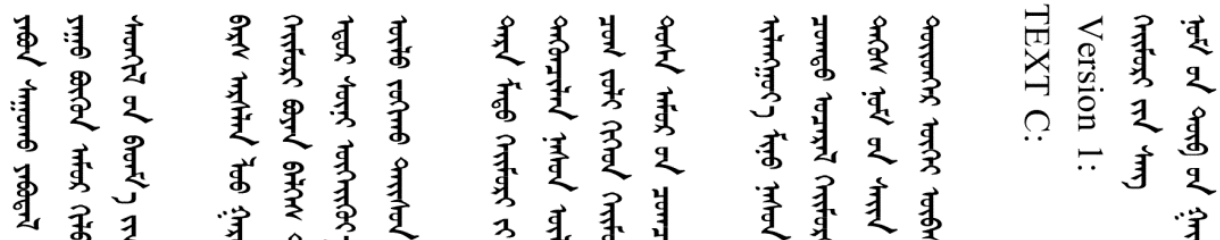

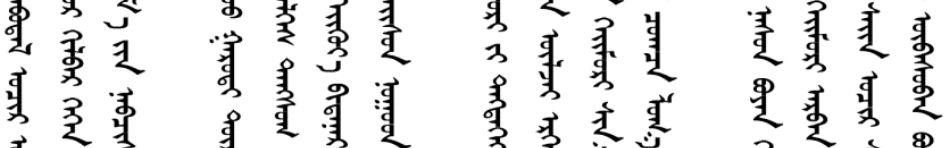

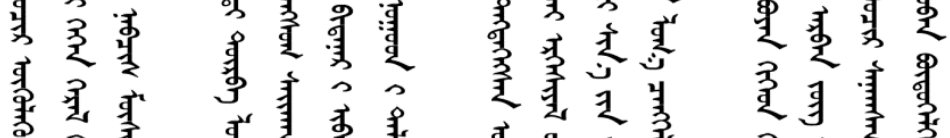

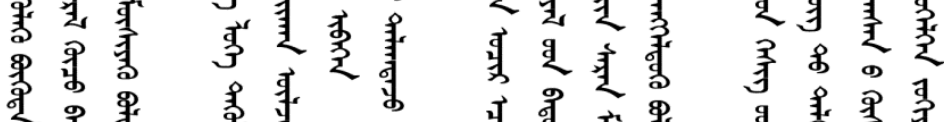

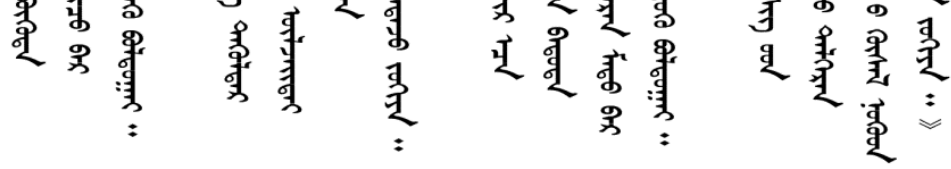

等

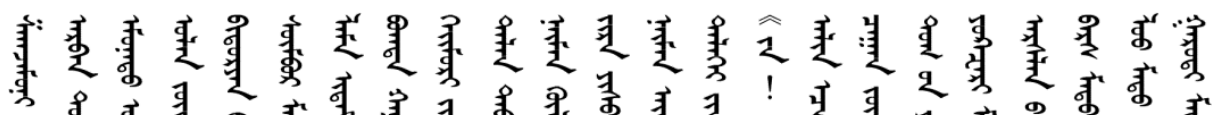

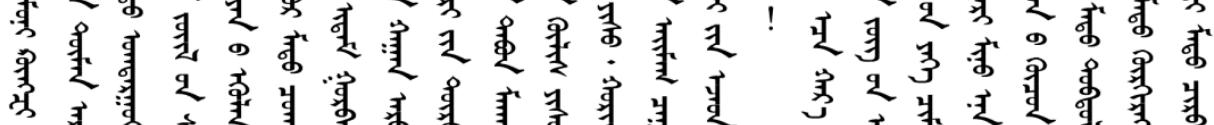

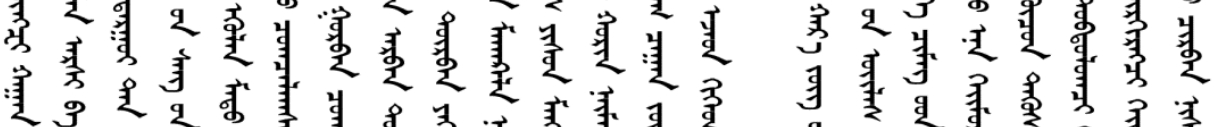

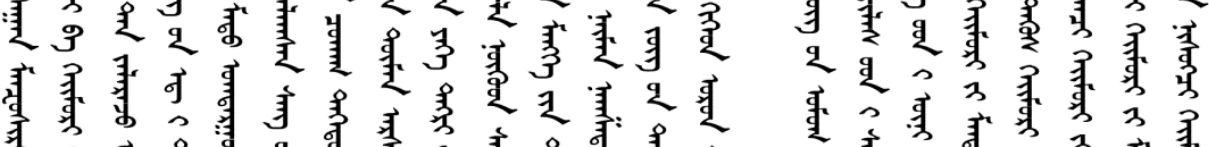

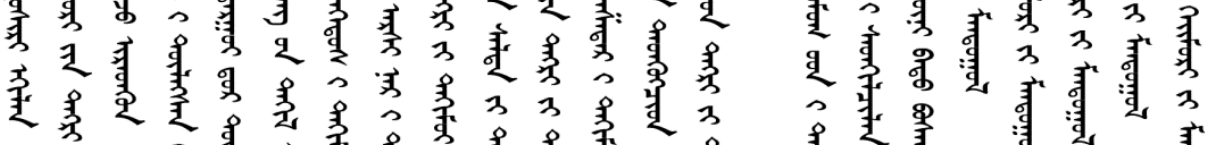

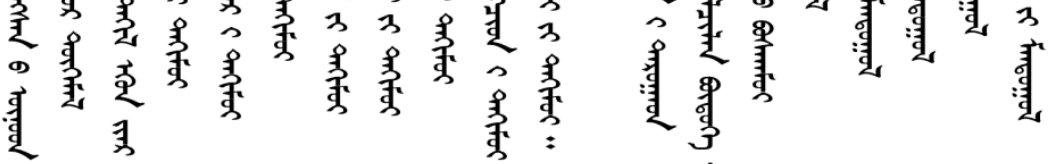




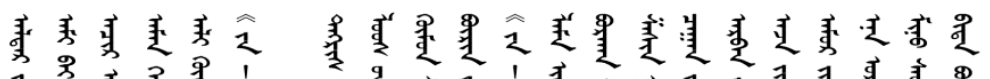

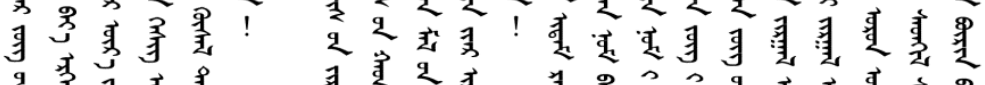

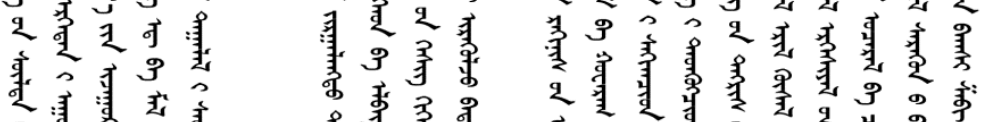

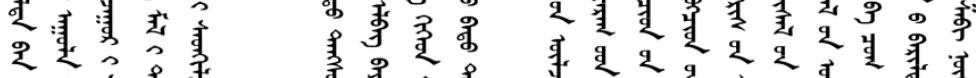

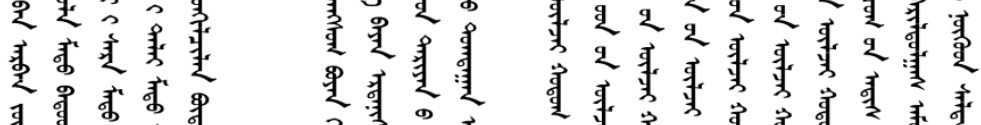

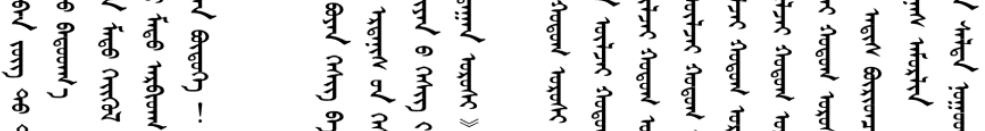

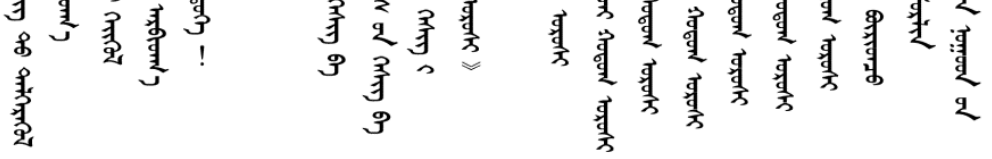

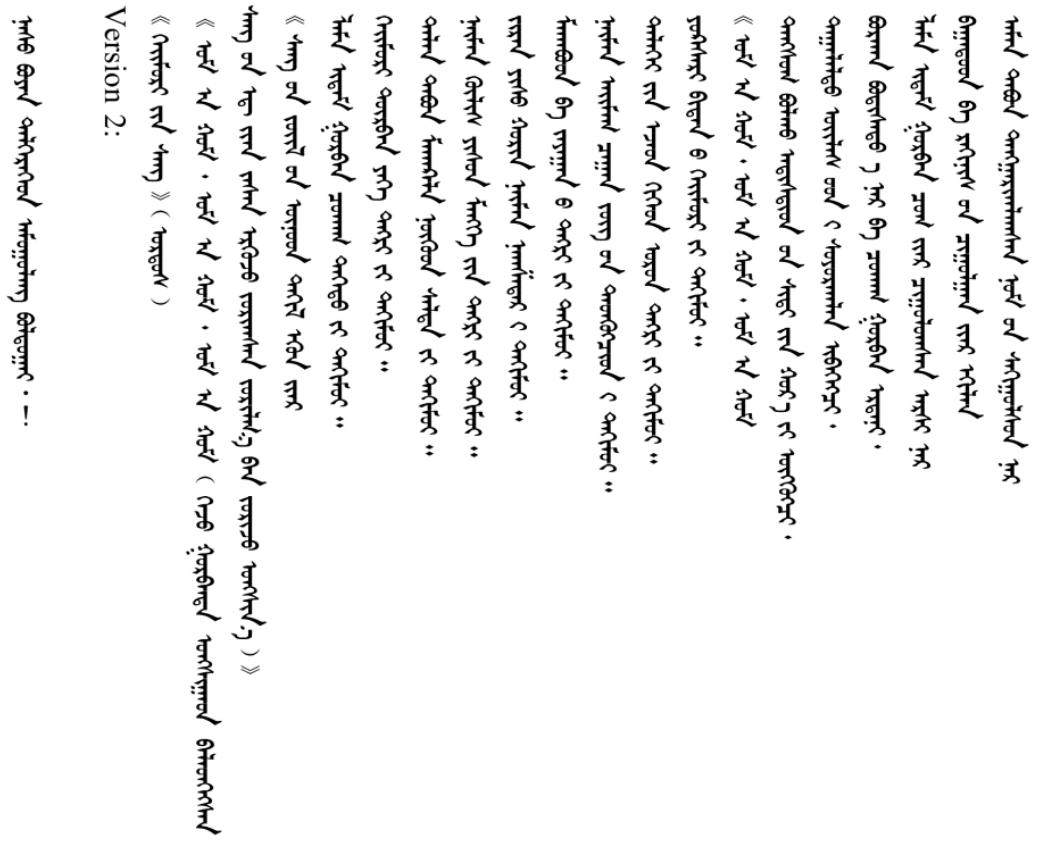




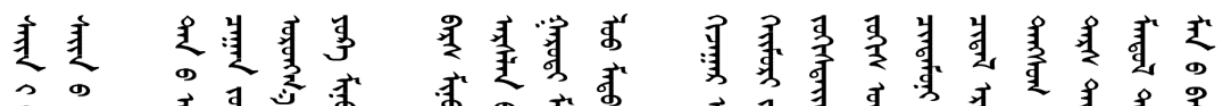

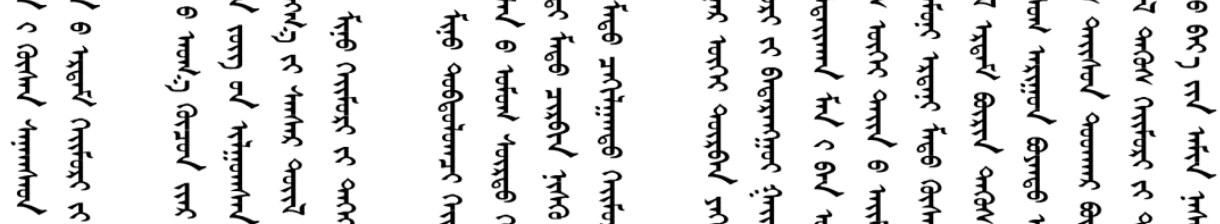

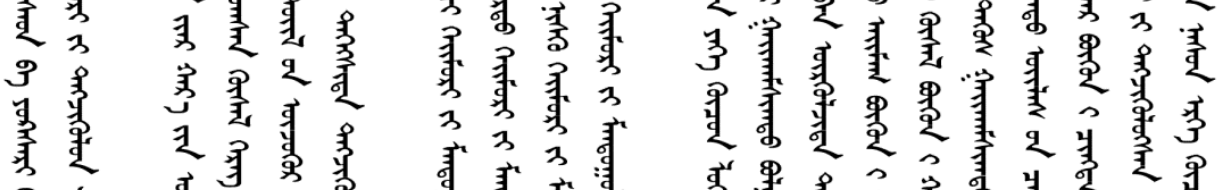

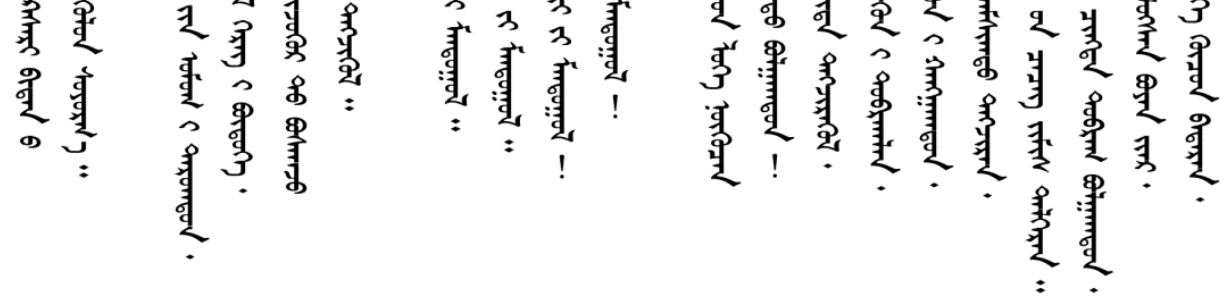

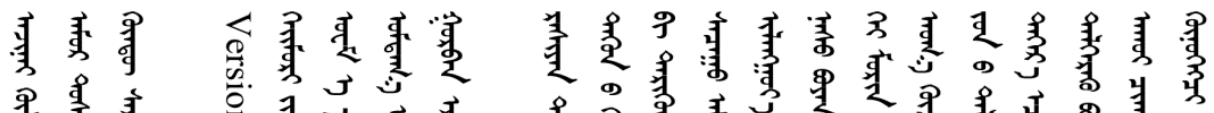

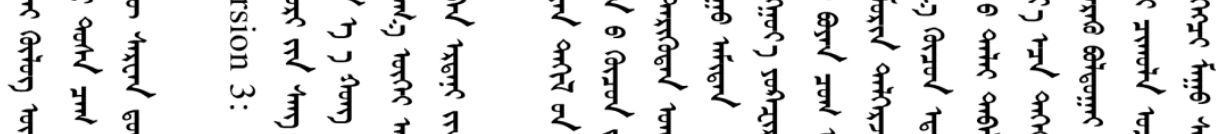

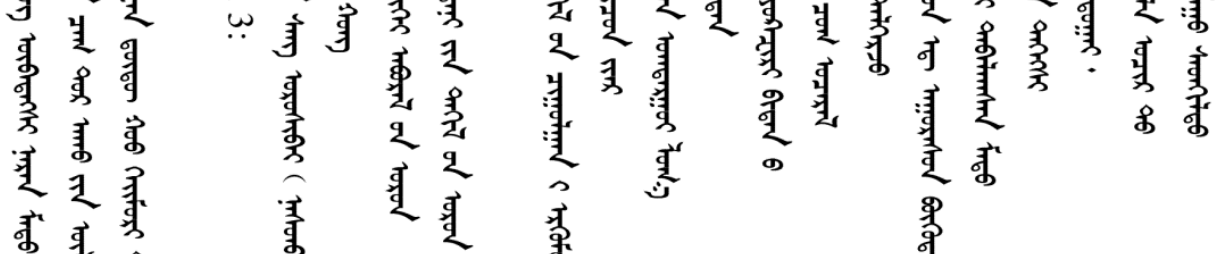

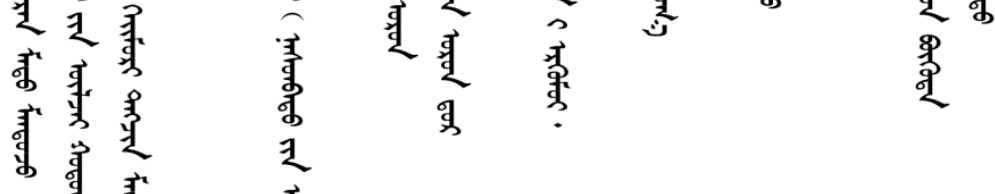




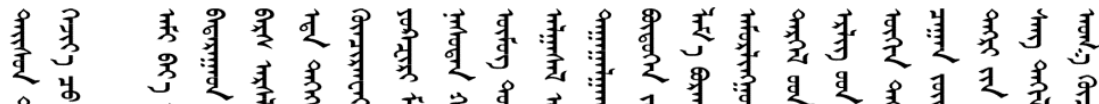

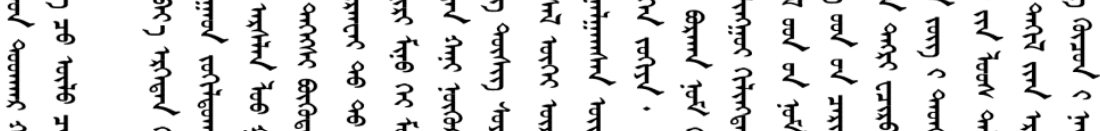

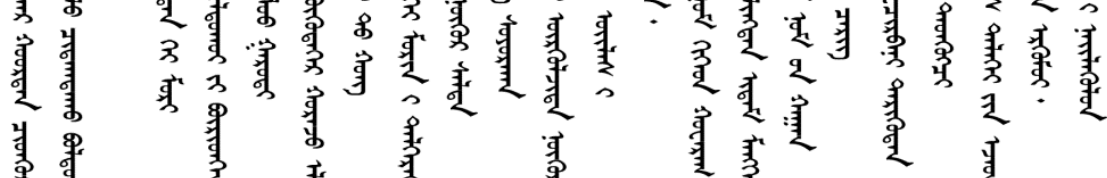

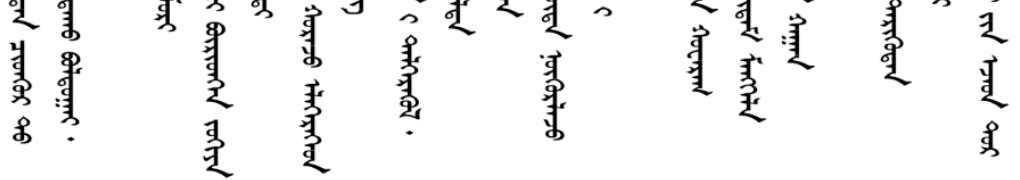

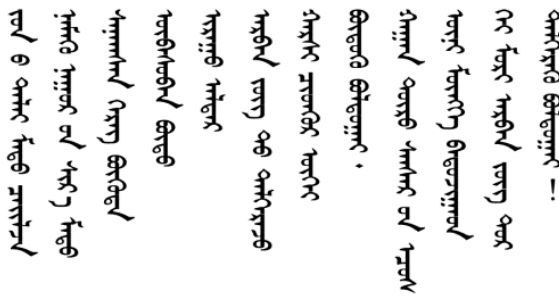

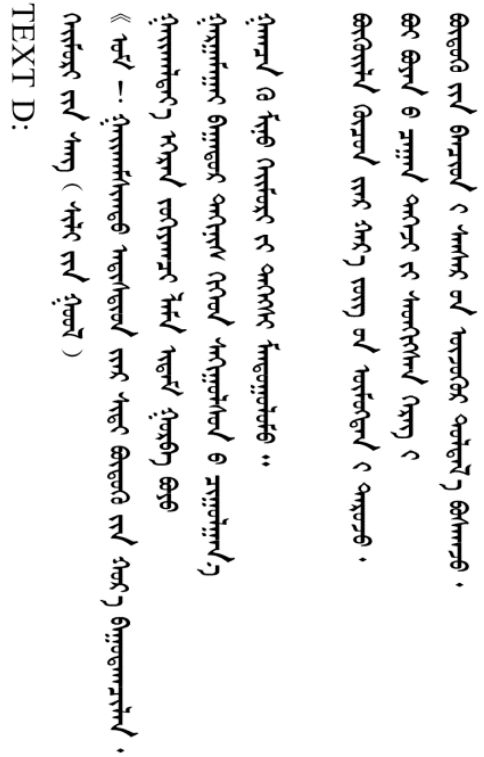




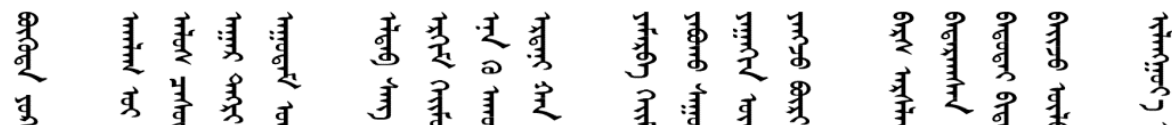

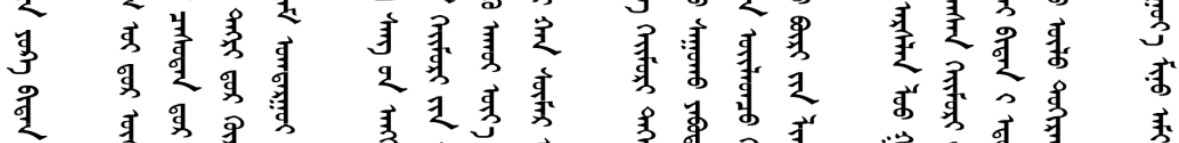

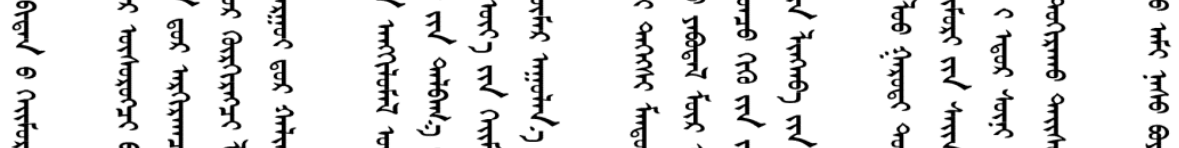

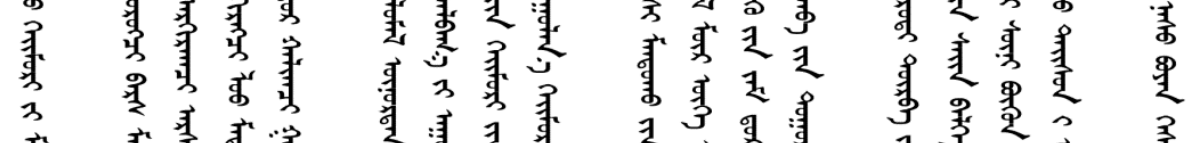

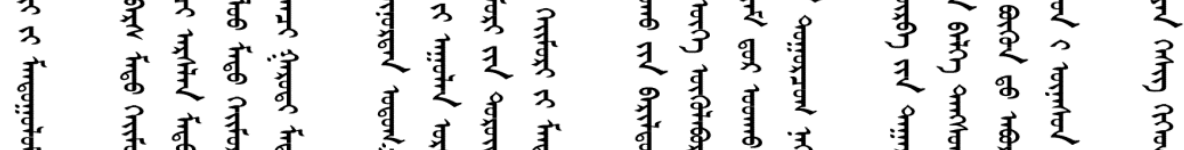

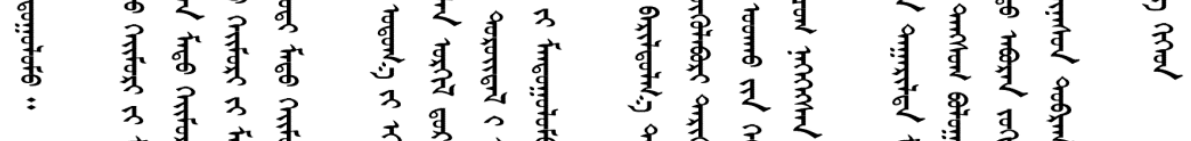

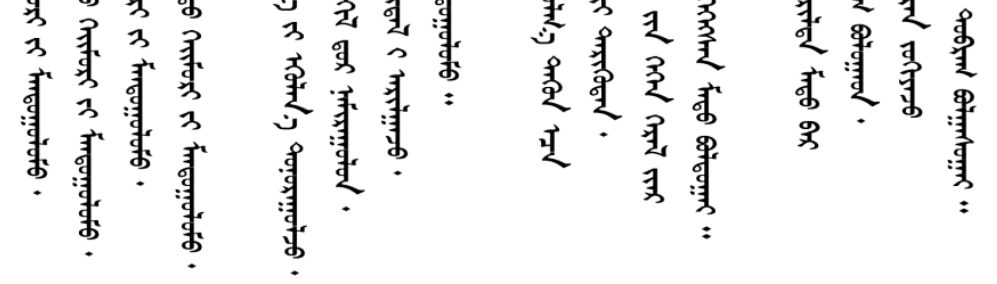

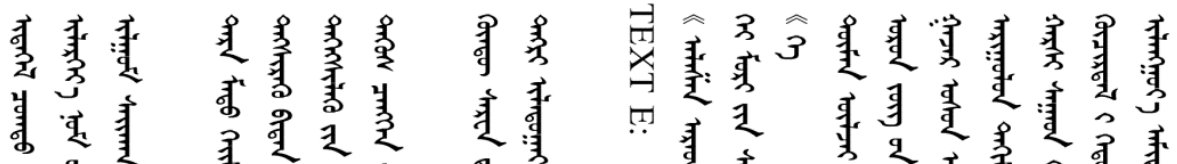

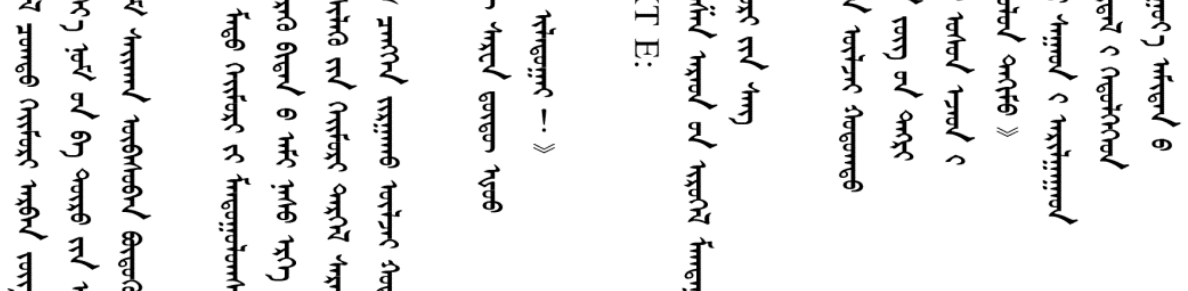

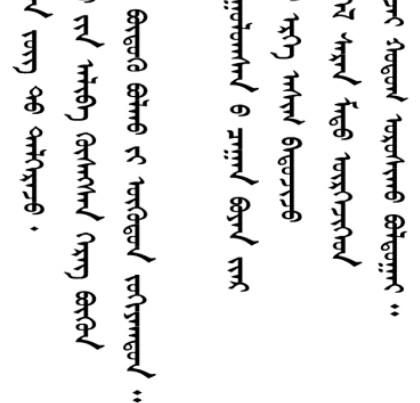

I 


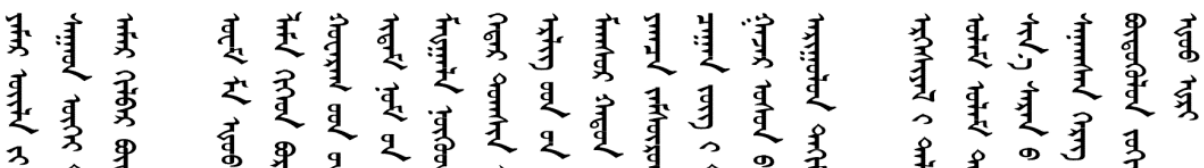

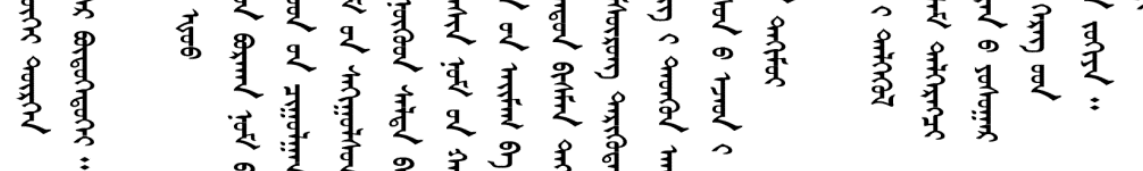

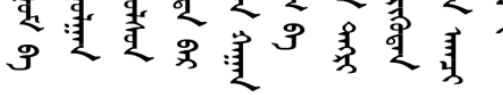

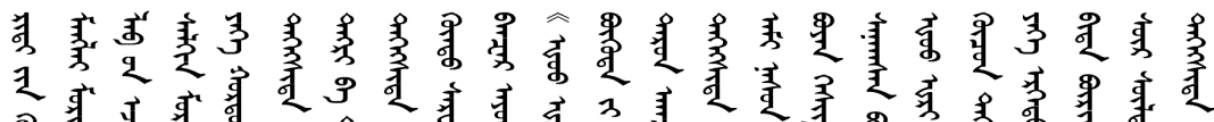

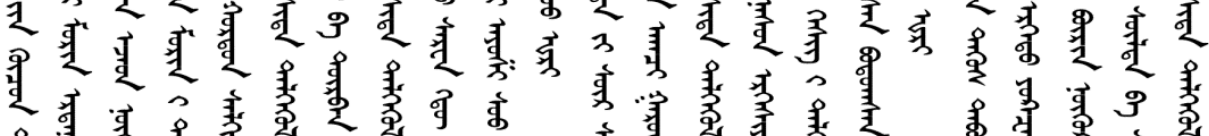

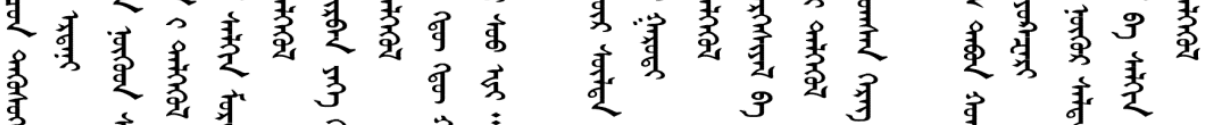

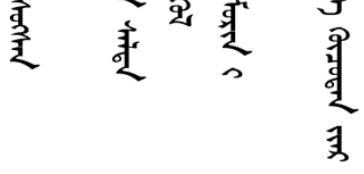

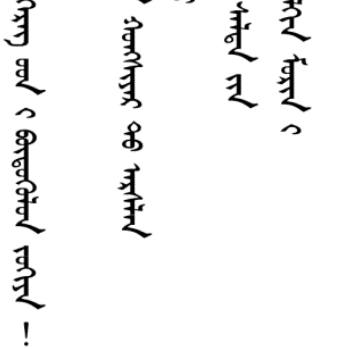




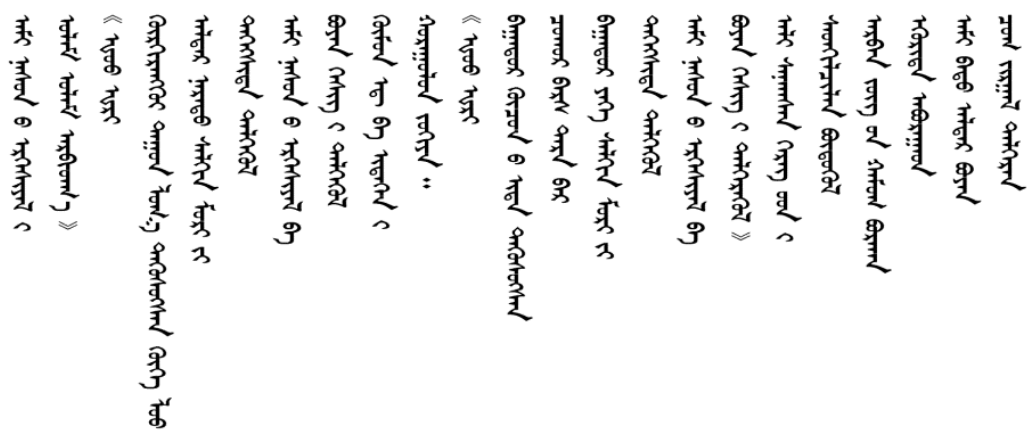

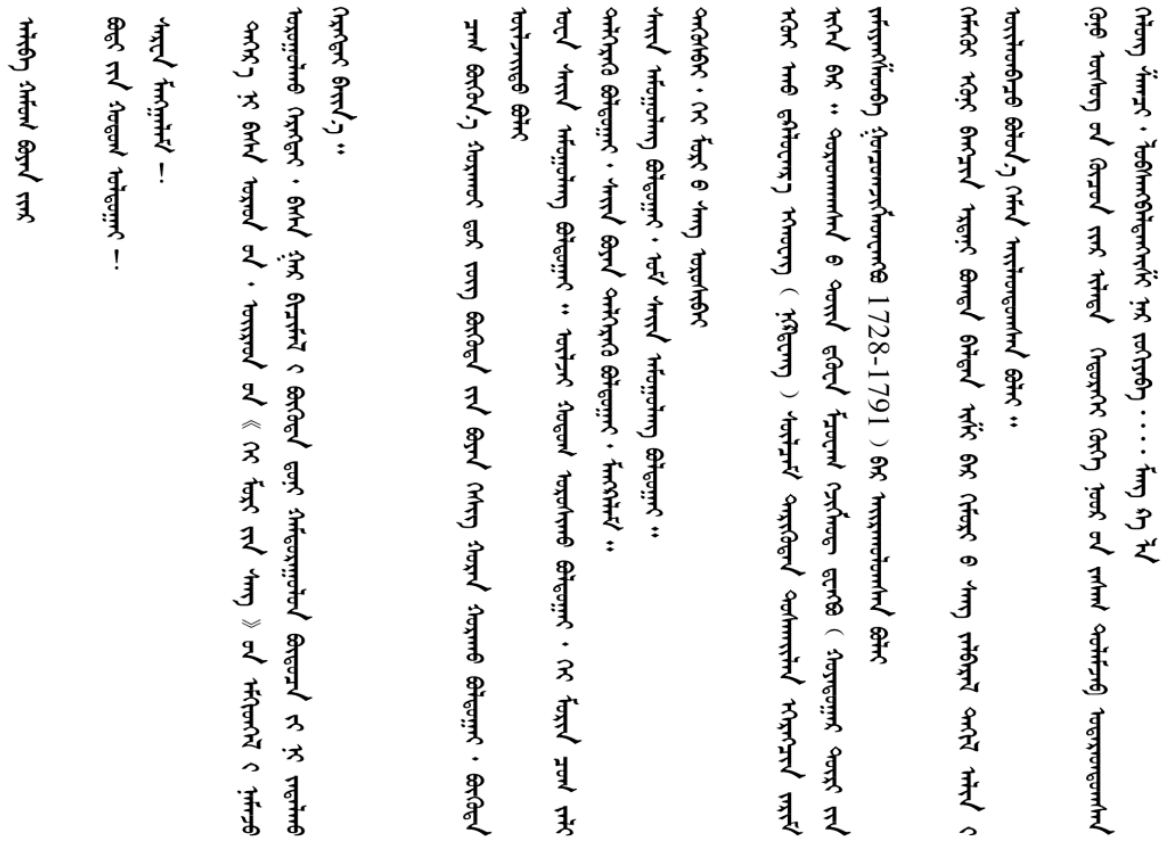


The second text, the keyimori-yin sang edited by Qoyaduyar dïri-yin Jamiyang Gegenten Jamiyangšadba Yoncogjigmedwangbu, was spread geographically to Ordos, Alaša and Silingool, Jirim and further localities (TEXT B). As a result, the content of these two texts is very simple. I would personally draw the conclusion that Qoyadugar dïri-yin Jamiyang gegenten Jamiyangřadba Yončogjigmedwangbu's text is based on Mergen gegen Lubsangdambijalsan's text.

Many sangs for the keyimori are marked by frequent Buddhist references and many fewer references to shamanism. Keyimori-yin sang texts contain many Tibetan and Sanskrit words and mantras. In Ordos, another common version of keyimori-yin sang (TEXT C) has been influenced not only by Tibetan but also Indian and Chinese cultural references, for example: "From the hermits of the wondrous, peaceful Dharma palaces of Ordos, beginning with Šagjamuni, Lord Kungæi (Confucius), and Manzusiri, may there come ten thousand hermits and keyimori to the south sky."

"In the offering, many kinds of incense were lit, with a fragrance like a green jade cloud perfected in the sky, illuminated like Mount Sumber (Meru); with this the lamas make an offering to the three precious tutelary deities, offerings to the ten thousand hermits of Bogd Khan are made, to the four great Tengri of the keyimori, offerings are made, to the seventy-five Maqayalas and their consorts, offerings are made, to the Tengri of the wrathful deities of the eight incenses, offerings are made, to the protector of the white direction, offerings are made, to the lords of the world, and the Tengris of the land, offerings are made."

nom-un töb-ün yayiqamsiztu ordu qarsi-ečegen šagjamuni küngzi qayan manzusiri ekilen arban tümen arsi ba keyimori-yin tengri emünedü oytaryui-tan jalaraju iredkün

olan jüil-ün sang-un ed-yi tülegsen-ü ünüd ber bidüriyen-ü egülen metü oytaryui-dur tügemel sümbür metü cogčalagsan sang-un takil egün-iyer lama idam yurban čnqag degedüs-yi takimui boyda qay an arban tümen arsi nar-yi takimui keyimori-yin dörben yeke tengri-yi takimui dalan tabun maqayala nökëid selte-yi takimui naiman kulis yisün mengge-yin tengri-yi takimui naiman ayimag čay an jüg-ün tedkeiggřid-yi takimui delekei-yin ejed kiked orun tengri-yi takimui

The editor and the period of origin of this text (TEXT C) is not clear.

The keyimori-yin sang composed and edited by Mergen gegen Lubsangdambijalsan (TEXT A) is a prayer addressed to the Buddha through figures of a lama, hero and spirit. Contrastingly, the Ordos keyimori-yin text (TEXT C) addresses as its object of prayer the khaan, the 100,000 hermits, the four heavens of the keyimori, the 75 maqayala, the nine birthmarks, 28 stars, the patron of the white direction, and the ruler of the earth.

Many keyimori-yin sang texts have features that bear traces of high or priestly religious culture. One notable feature used in the Sili-yin youl texts of the keyimori-yin 
sang (TEXT D) is that of alliteration. The content of this text is similar to Qoyaduyar duri-yin Jamiyangšadba Voncogiggmedwangbu's text (TEXT B). The termination of the written text (colophon) reads as follows: "tere metü keyimori-yi man-

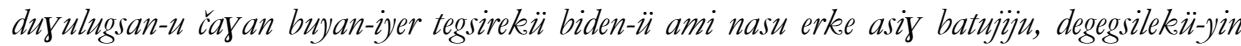
keyimori tergel saran metü örgejiged, tegüs čenggen jïryaqu öljei qutug orosiqu boltuyai. gündü sarwa düdü ekü tengri ilatuyai". It is addressed to the human world, as a prayer for health, long life, thriving keyimori, and success in all things.

The text used in Alašan (TEXT E) commences with the words: "tümen öljei qutuytu, oron jüg-ün tngri, gajar usun ejed-yi ariyulun takimu”; in translation, first making an offering to the owner of the grassland (pasture) and water. For success and luck, it is a common practice to make such prayer addresses to the owner of the grassland and water. The text contains references to "mansur qatun, bisman tngri, yagra jamsarang, banzar ayusi".

In the course of social development, the keyimori-yin sang has understandably changed. One crucial shift is the transfer in worship among the Mongolian people from shamanism to Buddhism. As a result, the present keyimori-yin sang has both features of shamanism and Buddhism.

\subsubsection{The content and trend of keyimori}

The keyimori-yin sang has four main referents.

\section{(1) Nature}

The first words in the text are: "om a qum, tangsug bolqu adistid-un sidi-yin qura-yi

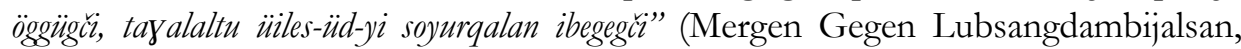
TEXT A), which can be translated as: Om a hum, the givers of joyous blessings who gather the spiritual powers, gracious protectors of pleasing meritorious deeds.

In the Alašan text (TEXT E), the words read: "tümen öljei quturtu oron jüg-ün tengri, yajar usun ejed-yi ariyulun takimu", which is a prayer to heaven and the owner of the grassland.

"Qarsi sayad-yi arilyayad küčirdel-yi getülgeged ilangyuy-a amitan-u yamar üile-yi sayad ügei türgen amar kilbar bütügetügei” (Alašan text, TEXT E). The text asks for removal of obstacles, overcoming hardships and a smooth course of life.

The above introductory text can also involve a prayer to the owner of grassland or water, to Buddha, to pray for rain or health, long life and so on.

\section{(2) The human world}

These texts address the world of human society, praying for health and long life for all, as well as success in all things: for example, "mandul tegüs keyimori-yi degjigülügsen buyan-bar, man-u beye-yin amin nasun-yi erke kü̈ün badaran" (Mergen Gegen Lubsangdambijalsan, TEXT A). "Tere metü keyimori-yi degdegegsen učir-ača tegünčilen nasun öljei erkesiyel-üd batuta čoy jali kiged keyimori sin-e-yin saran metü-ber tusa amur-un čof̌́a luya 
čngkeldükë̈ bolturai" (Qoyadurar düri-yin Jamiyangšadba Vončoyjigmedwangbu, TEXT B). "Aldar jüg-ün sülde-ben arban jüg-tü delgeregül, ami bey-e erketen-yi ay ula metü batudq-a, ă̈i ü-re-yin ijay ur-yi sara metü geigül, aman kesig ba mal-yi dalai metü arbidq-a, ali küsel tayalalyi sedkilcílen bütïge " (Ordos text, TEXT C)

In all of these texts cited above, the central idea is for all persons to find enjoyment in their lives, happiness and success in their prayers, and similar sentiments.

In general, the objective behind the raising of the keyimori is expressed as "minü nasun buyan kiged kesig kei mori arban jüg-tü delgeren-e, nom-un sansar duraduysan tus-ud kesig ügei bütïkï" via an explanation from an astronomical text. ${ }^{15}$ Here, the meaning of the explanation is that reading or reciting the keyimori-yin sang will bring good luck and success in life.

\section{(3) The consciousness of religion}

The text contains the words čayan jüg (white direction, i. e. the good direction in Tibetan) and "qar-a jüg" (the black direction). For example "tan-u auy-a küčün-iyer qar-a-yin omoy-yi daruytun, čayan jüg-tü ilayuysan küsel kereg-yi bütüge" (Mergen Gegen, TEXT A). Here, the translation can be as follows: "with enormous strength, may black pride be defeated; may the victorious desires of the white direction be accomplished."

"Ulayan-ača qara jüg-ün omoytan-yi daruyad, čayan jüg-ün üiles-yi sedkilčilen bütüge" (Ordos, TEXT C).

The text above speaks of opposing the black direction with good work and success, and to continue the keyimori-sïlde, along with the raising of the keyimori and other practices, for all time to come. Here, it should be noted that both shamanism and Buddhism make the offering of incense.

(4) The four dignities,

represented adorning each corner of a flag: the dragon, the garuda, the tiger, and the snow lion, along with the traditional keyimori pictorial representation of a horse. For example: "bars metü qalisqaqu-yin /speed in fleeing like a tiger/ keyimori-yi degdege / to rise, float up the keimori/, arslan metü omoysingy ui /omoysi- to be haughty like a lion/ keyimori-yi degdege, lun metï türčiginekii-yin/ to make loud sounds like a dragon, to thunder/ keyimori-yi degdege, garudi metü degden niskï-yin keyimori-yi degdege like the flying of the garudi” (Qoyaduyar dïri-yin Jamiyangšadba Yoncogjigmedwangbu, TEXT B).

The above text expresses the power of the four animals of the keyimori.

\footnotetext{
15 Altančečeg 1993, Qarasir-a-yin mongyolčud-un kei mori keyiskekü yosun. In: Öbür mongyol-un neyigem-ün sinjilekü uqayan. Kökeqota, 1993/4, p. 138.
} 


\subsection{Changes in the offering of the keyimori}

One major change that has been noted is that with many Mongolians moving from rural areas to the city, there has been a corresponding change in the practice of the offering of the keyimori. Originally, nomads or pastoralists hung the prayer flags in front of the house or yurt, but today, with many Mongolians living as full-time urban residents, without grassland or an open space to hang a full keyimori, the keyimori itself has been reduced in size. Most often, urban Mongolians place this small keyimori on a high place in the home or outside on the window ledge.

On the other hand, many Mongolians who live in a highly built-up area can also take advantage of open spaces by hanging a traditional keyimori after many persons make the keyimori offering together.

Another feature accompanying social development has been the appearance of keyimori-sülde stores in Ordos. I personally visited one such keyimori store last year in $\ddot{U} \ddot{u}$ in banner in Ordos. Originally, the post of the keyimori is entirely of wood, but today iron or other materials can be used.

Nowadays, many families prefer to erect two posts at the same time, each hanging four or five flags. By contrast, I remember that my family would raise only one post and had two flags (only the blue and red ones) only ten years ago, though now it is more common to have two posts hanging four flags (blue, red, white, green, every year being different). Still, Ordos Mongolians invariably place the post and its prayer flags in the same position: in front of the house, yurt, temple or ovoo. At the same time, Ordos Mongolians also continue with reading the keyimori-yin sang to the keyimori, (whether cloth flags or the previously noted paper keyimori) in front of the respective temple, elm or ovoo.

Conclusion: A preliminary survey of the keyimori in Ordos has been the main research objective. My own preliminary research into the forms of the prayer flags of Mongolia and Tibet promises to yield interesting material related to the subject of religious relations between Mongolian and Tibet, a topic that could be of considerable scholarly interest providing a new angle for the study of the cultural and religious relationship between the Mongols and Tibetans. I have noticed that characters and images on the keyimori cast an intriguing light on aspects of the relations between Mongolia and Tibet. At the same time, there is the significance that the keyimori has for the Mongolian people themselves. The block-print keyimori and the texts of the keyimori-yin sang display Mongolian history through their influence by shamanism and Buddhism. Above all, the oral keyimori-yin sang and its written text (combining both Mongolian and Tibetan texts) is a significant Mongolian cultural treasure. Continued study of the keyimori is important for Mongolian culture as well as scholarship. 


\section{References}

Lubsangdorji, personal interview, Prague, 31th March 2015.

Buyanwčir, personal interview, Kiy-a bagsi toyurig, Ordus qota, 5th April 2015.

Jiryal, personal interview, Üüsin qosiyu, Ordus qota, 6th September 2014.

Altančečeg 1993, Qarasir-a-yin mongyolčud-un kei mori keyiskekü yosun. In: Öbür mongyol-un neyigem-ün sinjilekë̈ uqayan. Kökeqota, 1993/4, pp. 138-139.

Bürintegüs 1999, Mongyol jang üile-yin nebterkei toli. Öbür mongyol-un sinjilekü uqayan-u teknig mergejil-ün keblel-ün qoriy-a, Kökeqota, p. 255.

Dosan, Ja. - Önir, Č. 2012. Zay-a bandita-yin šabinar. Sinjiyang-un arad-un keblel-ün qoriy-a, Ürümči.

Kesigtoytaqu, Č. 1998, Mongyol-un erten-ü udq-a jokiyal-un sin-e sudulul. Öbür mongyol-un arad-un keblel-ün qoriy-a, Kökeqota, pp. 152-153.

Lessing, Ferdinand (et col.) 1960, Mongolian - English Dictionary. University of California Press, Berkeley and Los Angeles, p. 444.

Namjildorji 1992, Ordus jang üile-yin tobrì. Öbür mongyol-un soyul-un keblel-ün qoriy-a, Qayilar, p. 391.

Qorin nigetü tayilburi toli, 1979. Öbür mongyol-un arad-un keblel-ün qoriy-a, Kökeqota, p. 341.

Sodubilig 2006, Mongyol anggili kitad toli. Öbür mongyol-un suryan kümüjil-ün keblel-ün qoriy-a, Kökeqota, p. 354.

Sonum 2008, Ordus aman ayalyun-u üges-ün quriyangy ui. Nemen jasaysan debter. Öbür mongyol-un arad-un keblel-ün qoriy-a, Kökeqota, pp. 203-206.

Sungdui, Ögeled Qoyid 2003, Jiruqai. Öbür mongyol-un suryan kümüjil-ün keblelün qoriy-a, Kökeqota, p. 276.

Šayja 1994, Mongyol ügen-ü tayilburi toli. Dumdadu ulus-un ündüsüten-ü keblel-ün qoriy-a, Begejing, p. 370.

Temürčidür - Tangjoriy 2001, Töbed mongyol kitad qaričay uluysan yeke toli. Liyooningun ündüsüten-ü keblel-ün qoriy-a, Šenyang, p. 1595.

\section{Acknowledgments}

I would like to thank Dr Veronika Zikmundova and Rachel Mikos, M.A., for the tremendous amount of work and patience in helping me to finish this report. I also like to thank our funding agency, the China Scholarship Council, for its generous support. 



\title{
Iy̌il Cürüm from Kalmyckia and his role in transforming the Oirat script in Xinjiang during the early $20^{\text {th }}$ century
}

\author{
Ba. Batubayar Xinjiang Normal University, Urumchi - Xinjiang Association \\ for Oirat Mongol Studies)
}

Ijjil Cürüm came from the clan Čaatun (Čayatun) of the Torghut tribe of Kalmycks in Russia. He was born in Kalmyckia at a place called Ulan hoolai-yin hulhutu. Day and year of his birth are not known. In the 1940s he was active in the Usu region of Xinjiang. He studied at the Cayan obusuto hural, a Kure or temple, of his Čatun sub-tribe, and became a coyirai dacang-yin gelong (mon. gelüng = "monk"). When he had finished his studies of Tibetan Buddhism at the monastery school he became a Gebsi (Geshi), that is a learned monk. He then studied medicine at Manba Dacang with a Buryat teacher.

Around 1927-1928 he left Kalmyckia. In the 1930s he was active in Ürümchi publishing a newspaper in Todo bicig, i.e. the Clear script of the Oirat. He also became a teacher of Oirat script and writing. He must have been around 40 years old then. Later he settled down at Usu in Xinjiang and became a teacher at the school of the Headquarters of the Left Torghut Banner, also at the Seer school and at the jiryailatu school of the Right Banner, teaching Oirat script and writing, Latin and Russian script, mathematics and other subjects, thus educating many young Torghuts over the years. Amongst them are famous scholars like To. Badma (a leading linguist), Si. Norbu (later a professor at Xinjiang University), Garsa (later a leading cadre in Xinjiang), Bata (later vice chief editor of the Xinjiang Daily news- 
paper), A. Taibai (later a linguist and writer) and others. One of his students, To. Badma left notes, stating that in 1939 Ijil Cürüm was teaching at the Mongolian school at Čaatun. He was also an Emči or doctor. The Torghuts from Usu called him Ijil Cürüm, because he came from the river Volga, which is called Ijil in the Oirat-Mongolian language. Iǰil Cürüm settled down at Usu and took a wife called Olaka.

Cürüm devoted the second half of his life nearly entirely to the education of his people, the Oirat. His influence on the development of the Oirat written language was large. He collected great merits in the field of Oirat publishing and newspaper business. He was not only a Buddhist Gesi, but also a teacher and a doctor devoting his service to the common people. 


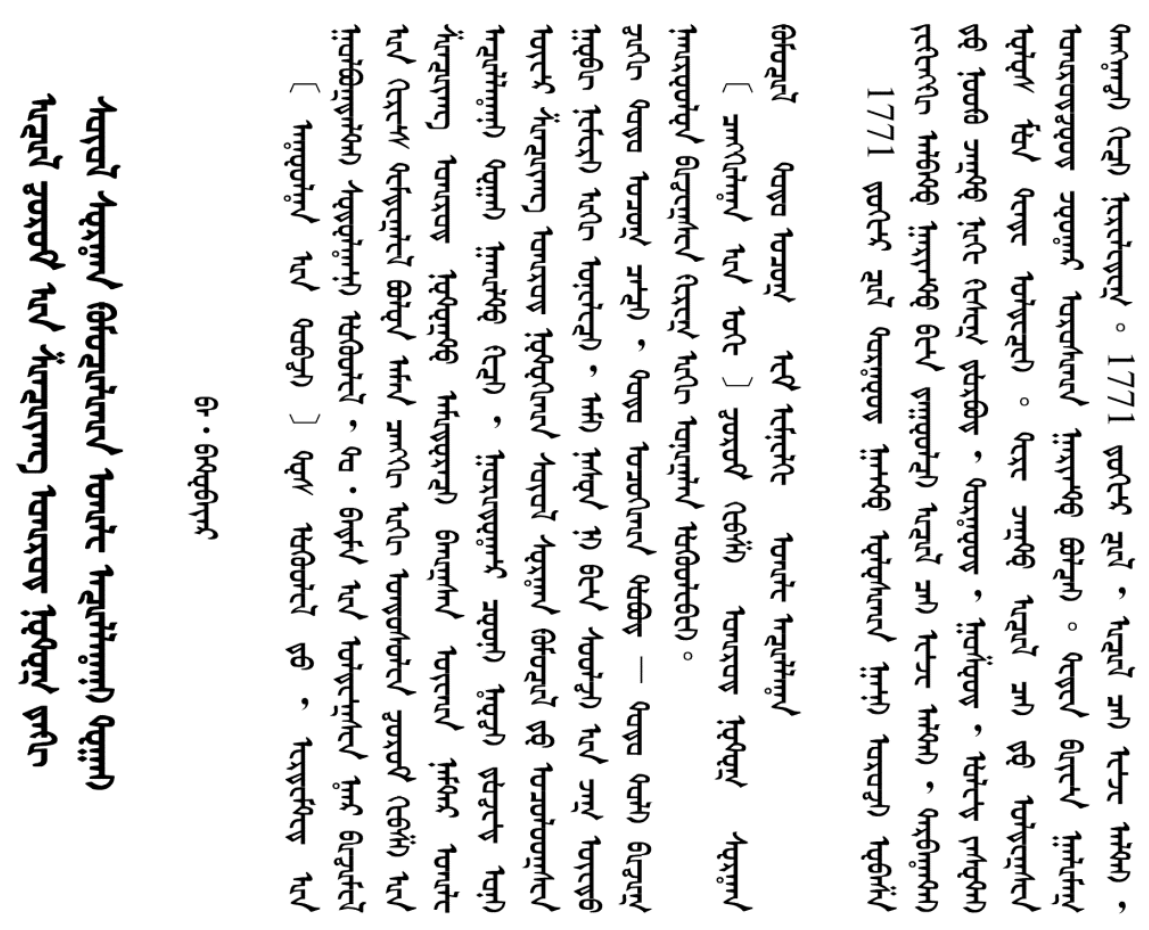

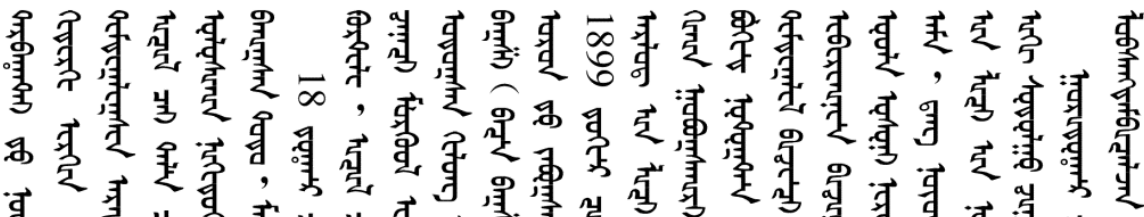

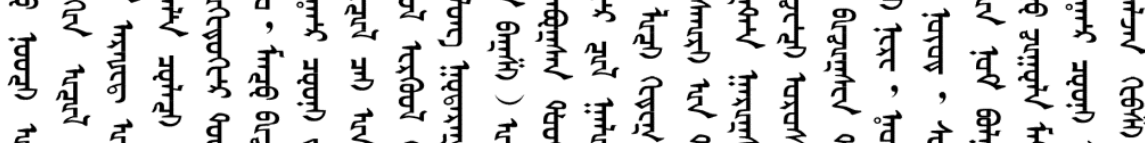

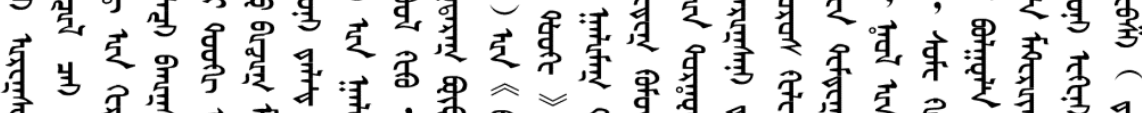

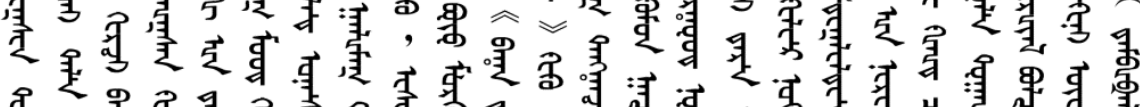

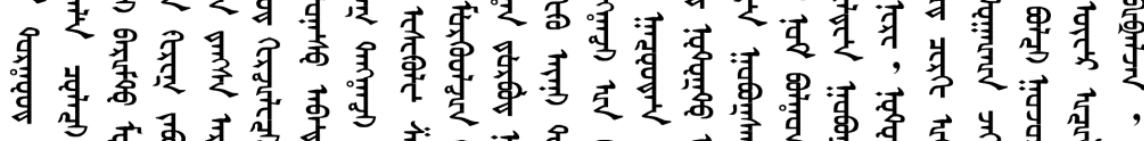

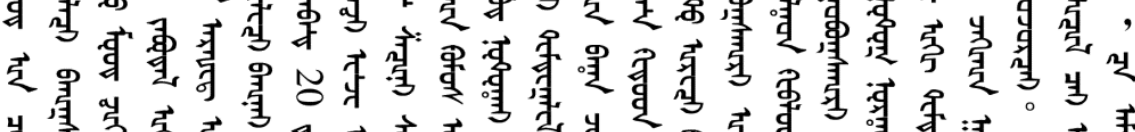

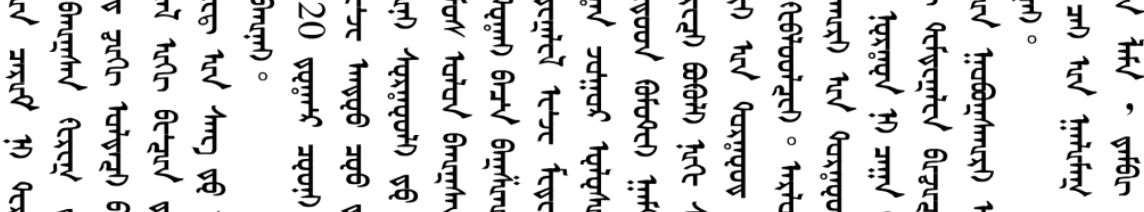




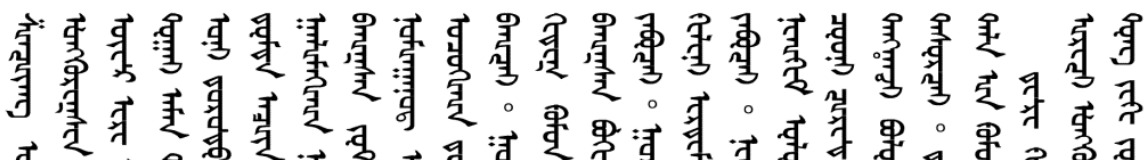

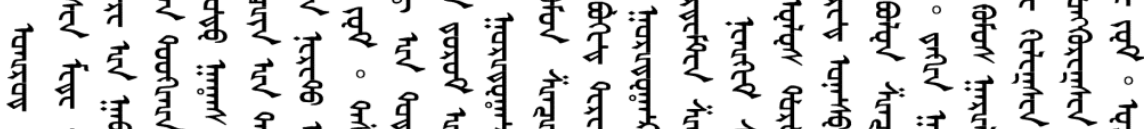

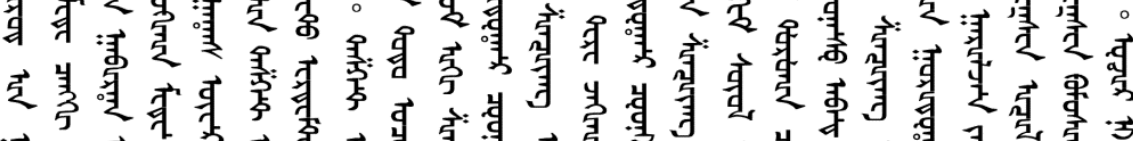
等

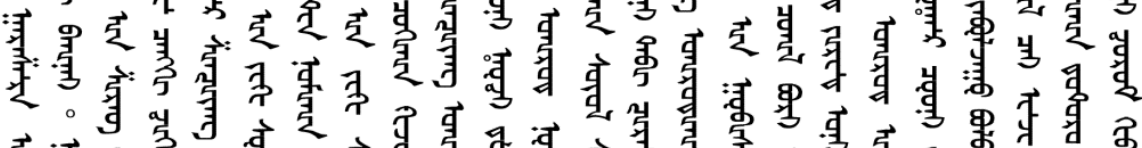

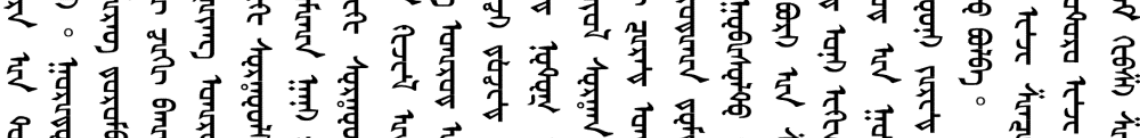

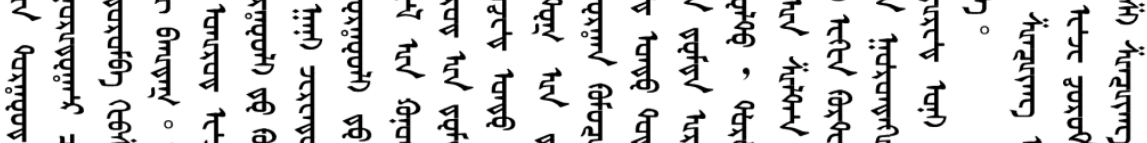

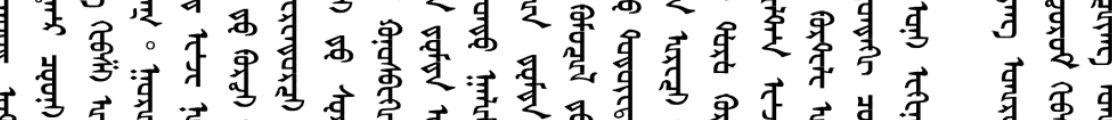

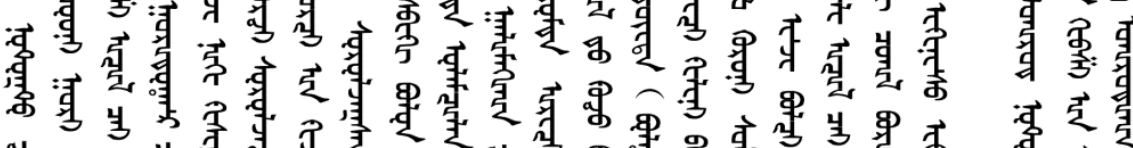

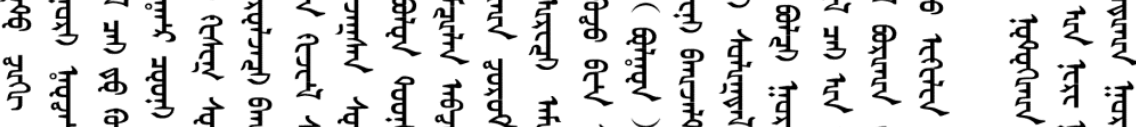

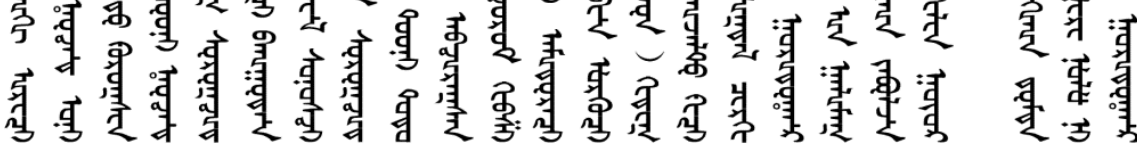

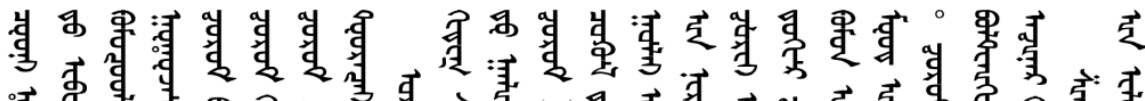

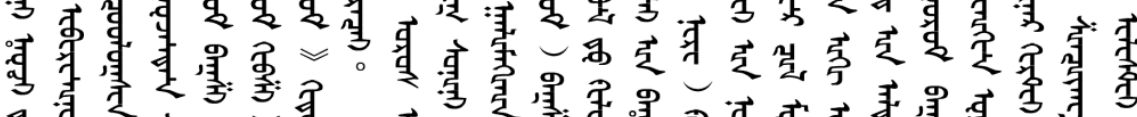

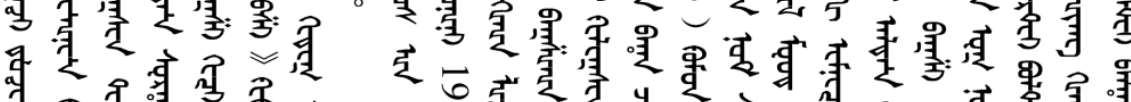

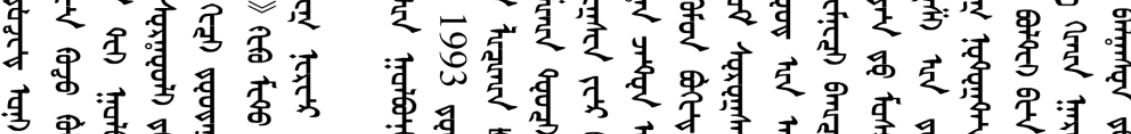

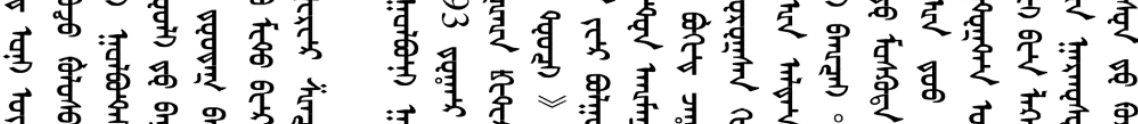

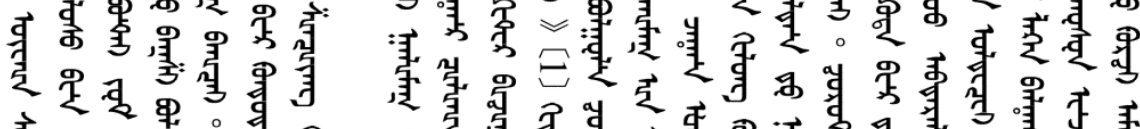

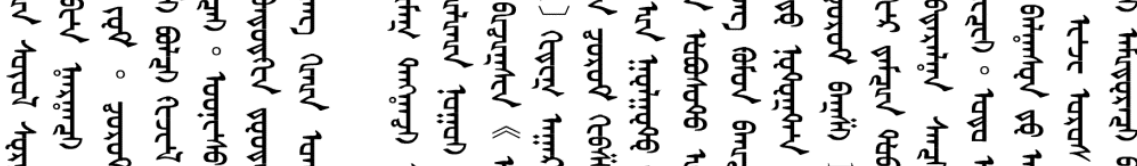

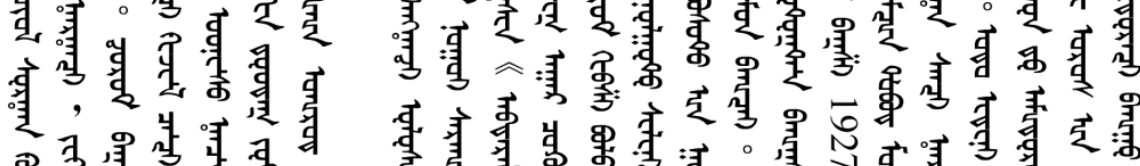

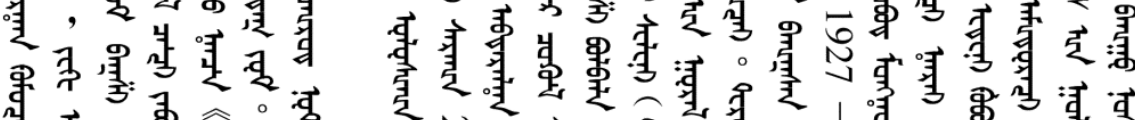

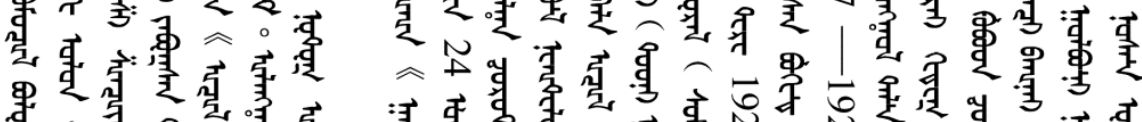

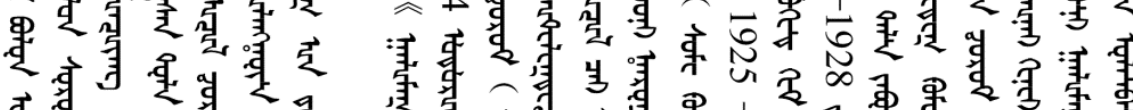

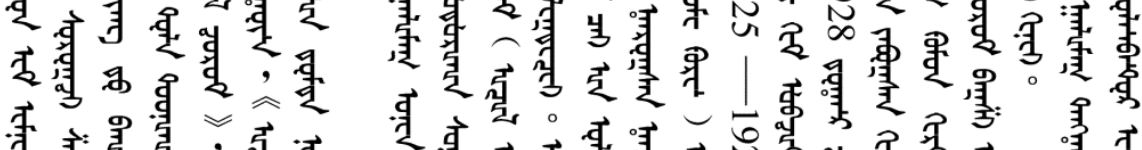

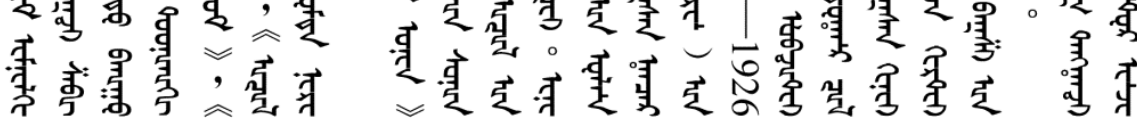




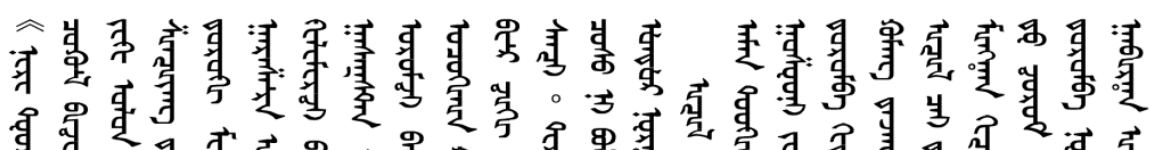

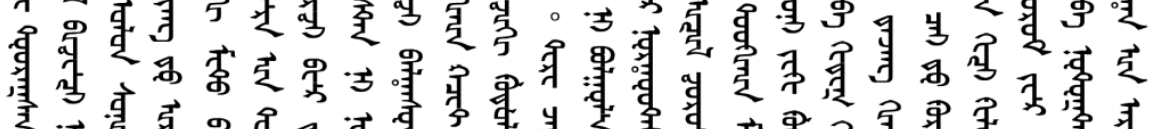

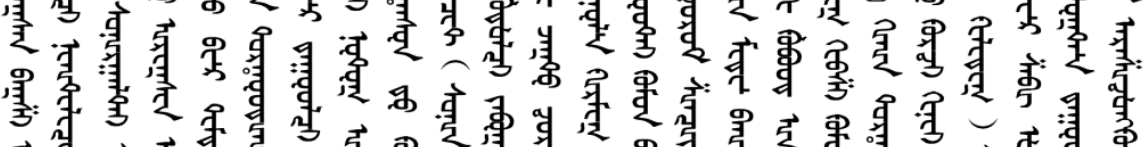

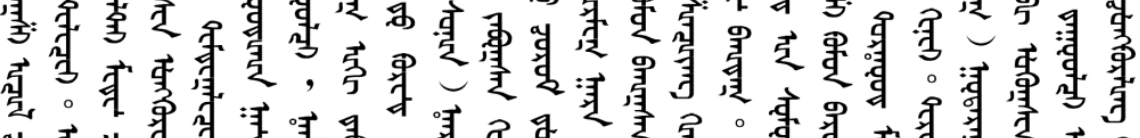

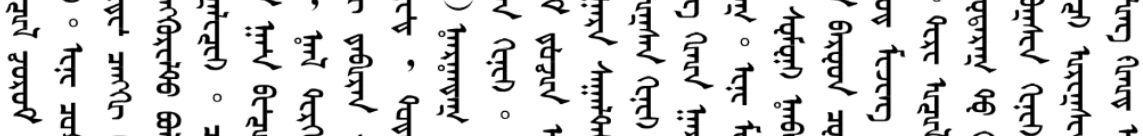

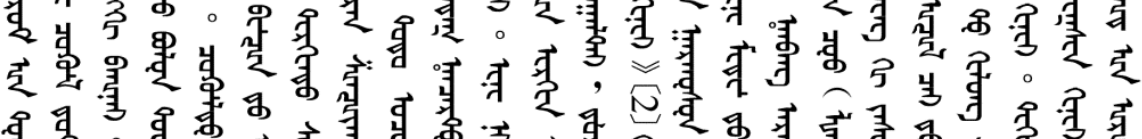

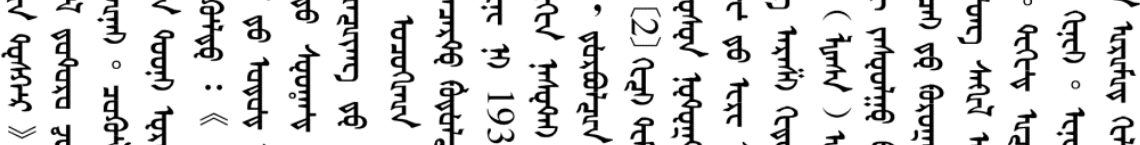

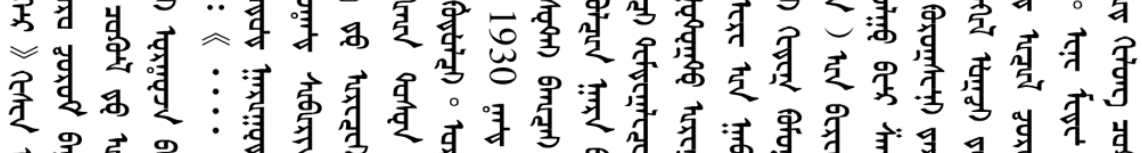

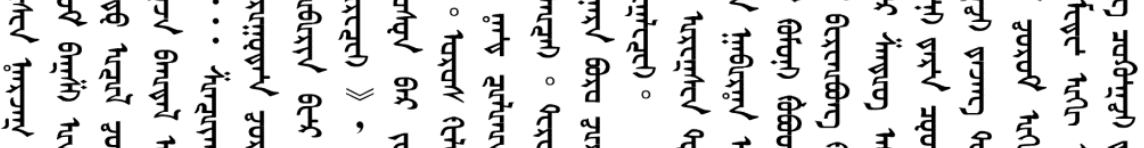

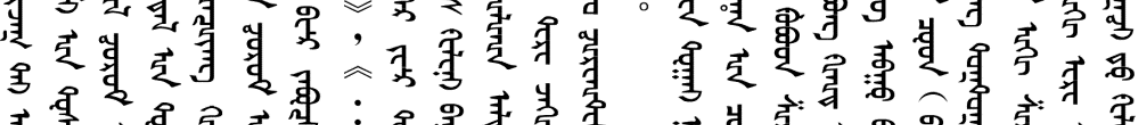

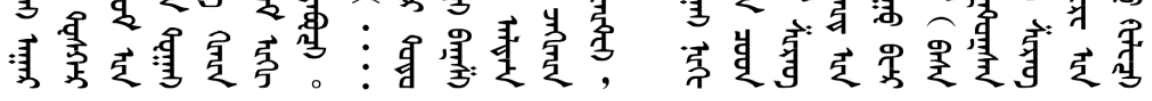

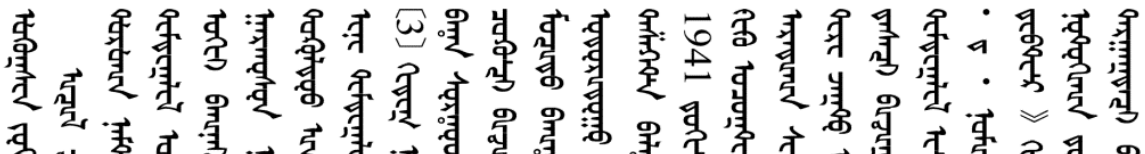

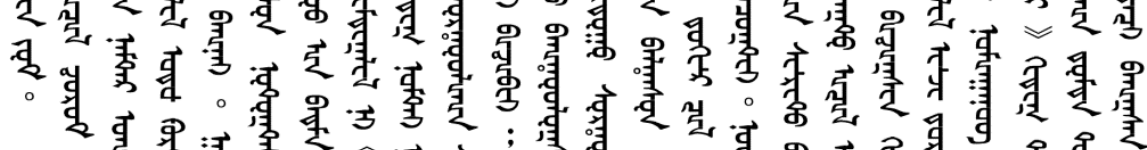

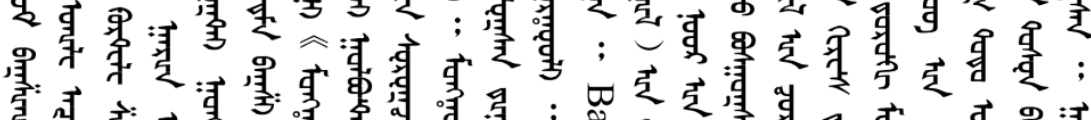

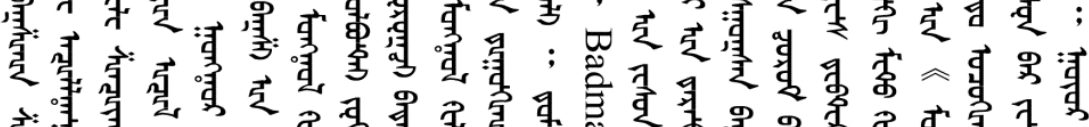

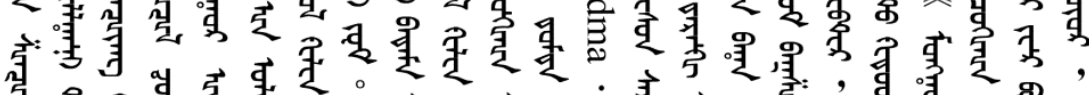

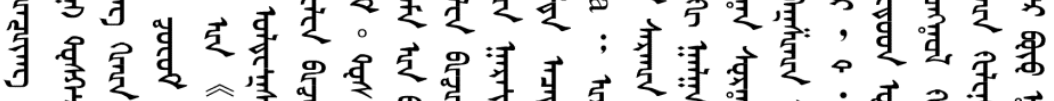

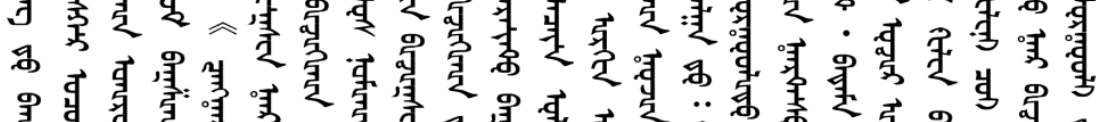

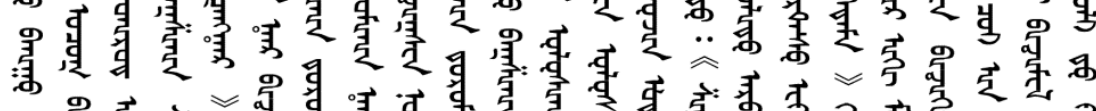

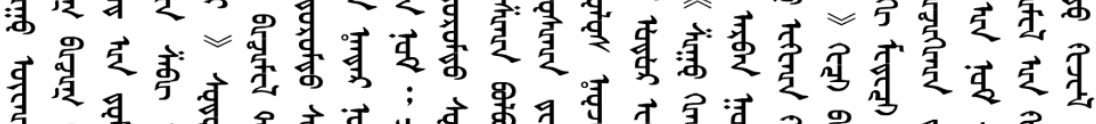

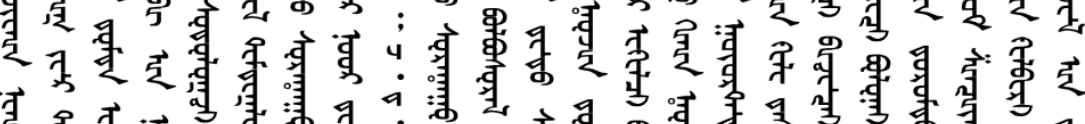

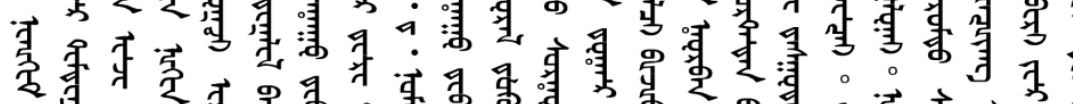

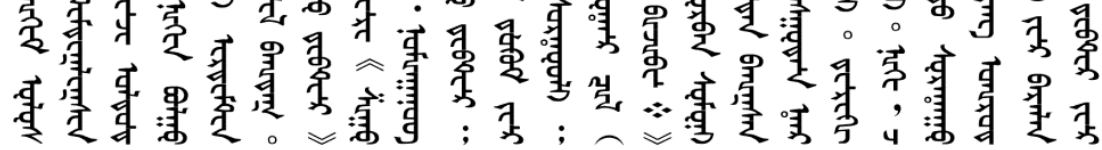




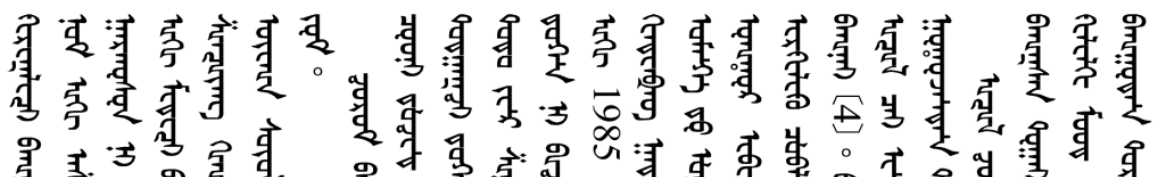

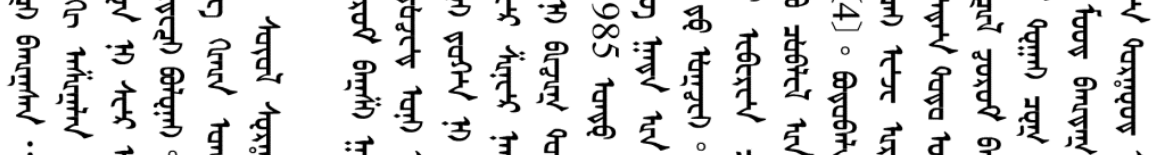

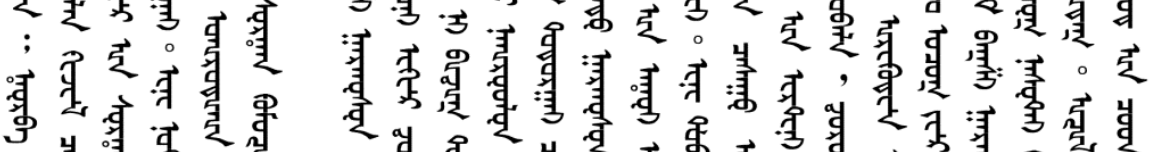

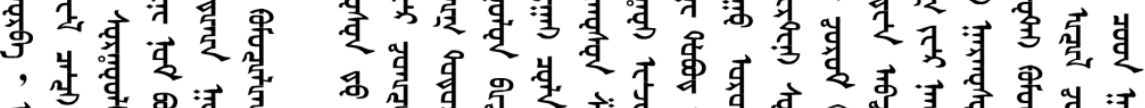

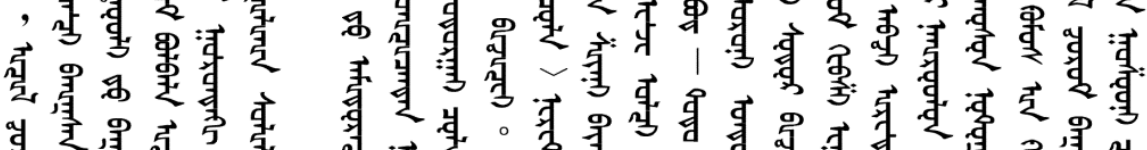

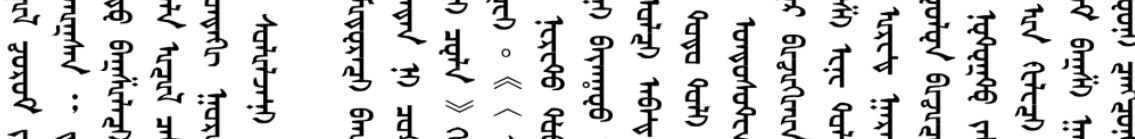

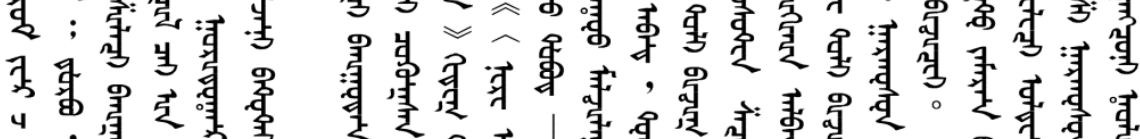

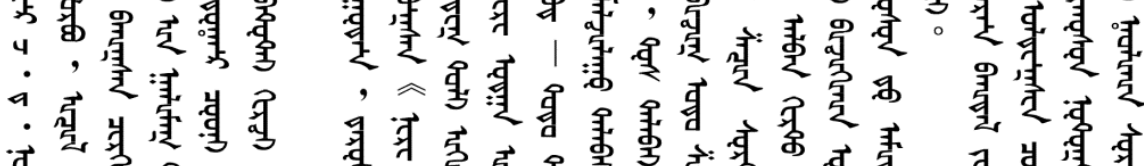

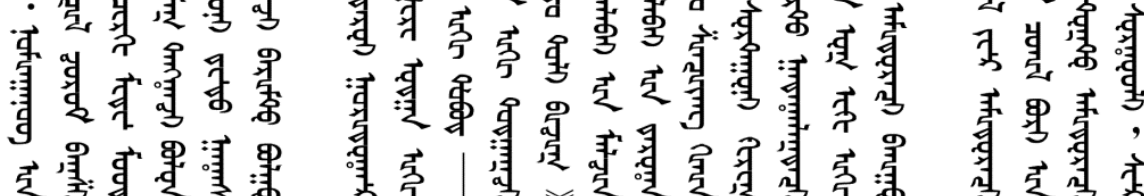

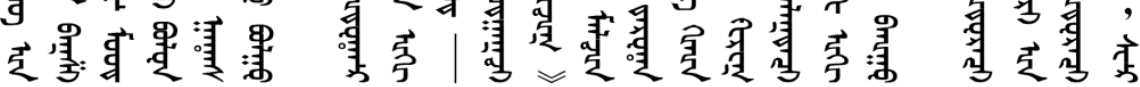

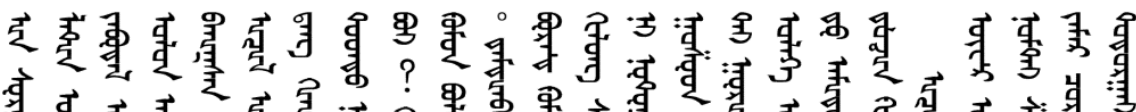

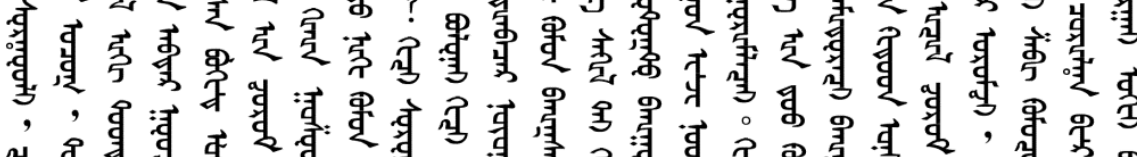

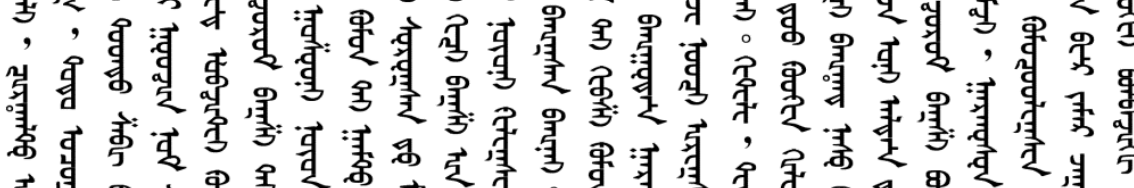

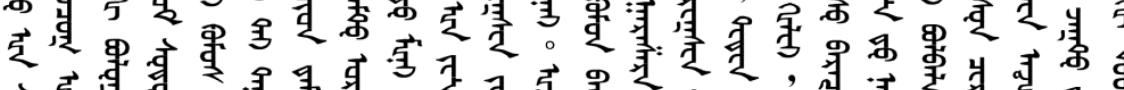

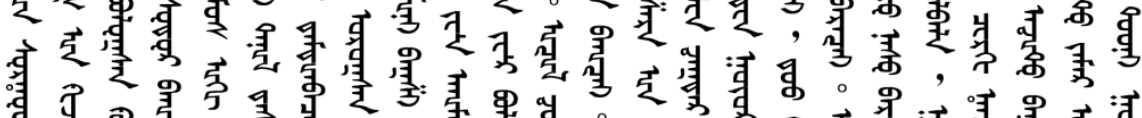

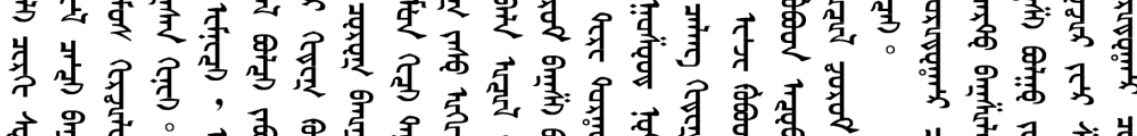

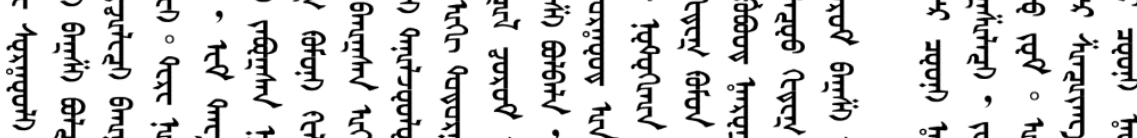

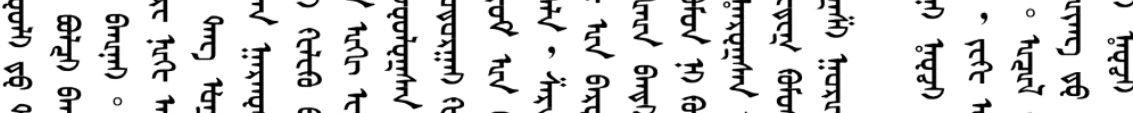

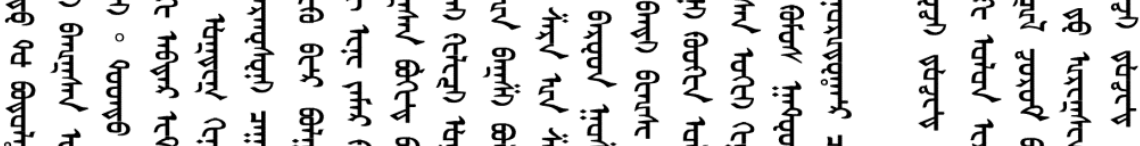

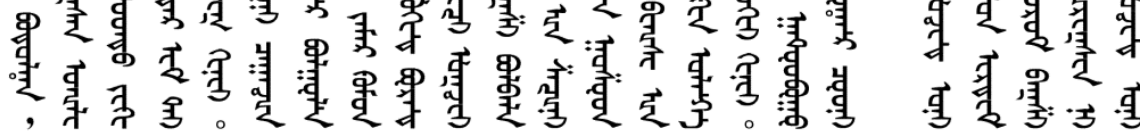




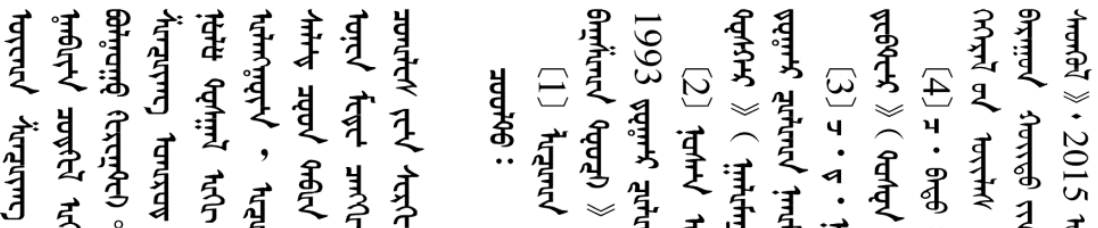

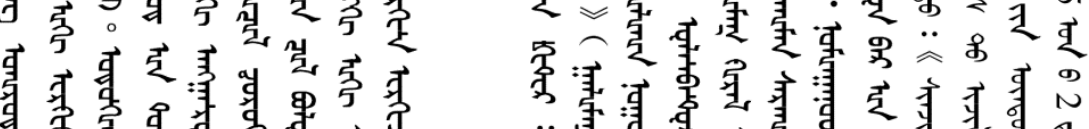

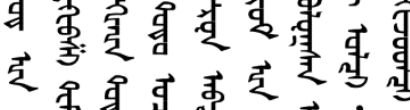

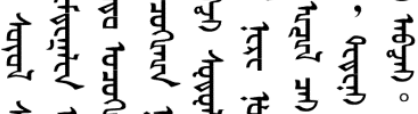

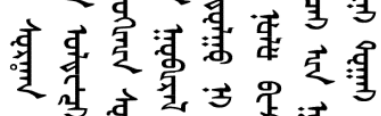

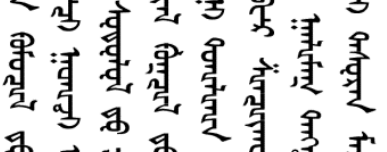

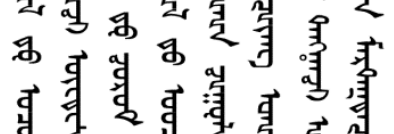

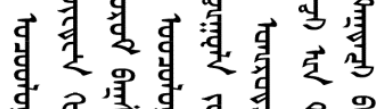

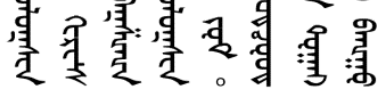

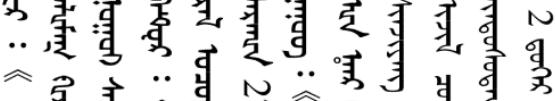

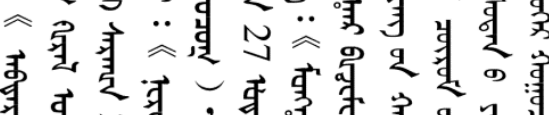

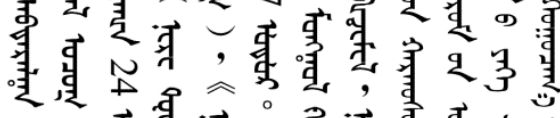

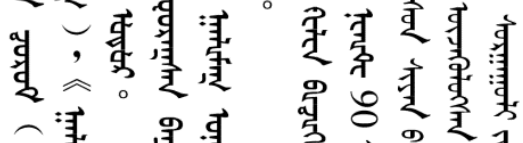

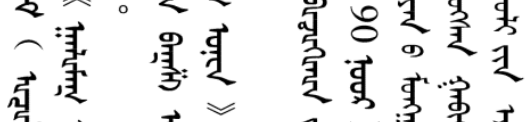

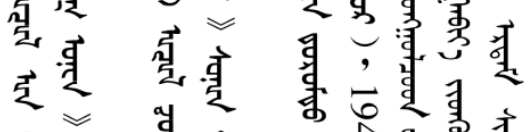

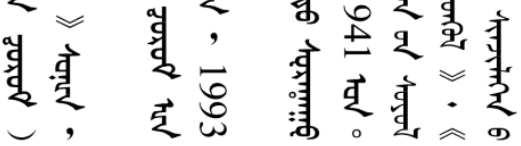

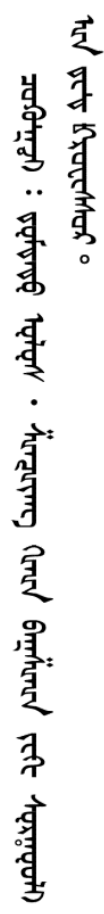





\title{
Gábor Bálint's Manuscripts of the $19^{\text {th }}$ Century Kalmyk and Khalkha Vernacular Kept in the Hungarian Academy of Sciences
}

\author{
Ágnes Birtalan (Eötvös Loránd University, Budapest)
}

\section{Abstract}

Gábor Bálint of Szentkatolna (1844-1913) was a Hungarian scholar with versatile interest and knowledge, but in the second half of his life with controversial ideas about linguistic affinity. His indisputable result is, however, the recording of large corpora of $19^{\text {th }}$ century vernacular Christianised Tatar (1871), Kalmyk (1871-1872) and Mongolian proper - a kind of Western Khalkha dialect (1873). The Tatar material was published by Bálint himself and later also issued by Árpád Berta. The manuscript of Mongolian dialectal materials attracted the scholarly attention of some Hungarian and foreign researchers, but the critically revised publication had been waiting for its release until the recent years (the Khalkha material is still under elaboration).

In the present article I am going to introduce Bálint's academic legacy focusing on the following aspects:

1. The linguistic value of the first large text-corpora of Vernacular Mongolian (Kalmyk and Khalkha).

2. Evaluation of the text-corpora as sources of that time ethnography, folklore and religious views of Kalmyks and Khalkhas.

3. The place of Bálint's heritage in the international Mongolian studies. 


\section{Introduction into Bálint's Mongolian manuscript material}

The manuscript legacy of Gábor Bálint of Szentkatolna (1844-1913), the Hungarian (Transylvanian) researcher is internationally less known, but he is quite admired by certain extremist movements in Hungary. His popularity rests on his unscientific ideas about the affinity of the Hungarian language and certain ahistoric conceptions about the origin of the Hungarians. However, at the beginning of his scientific career he produced scholarly books and unique manuscripts - unfortunately unpublished during his lifetime - of the highest academic value. For the Mongolian studies Bálint should be valued as the first scholar who recorded large corpora of the Kalmyk and Khalkha vernacular in a fairly good transcription perpetuating in this way the $19^{\text {th }}$ century pronunciation of two Mongolian languages.

The Department of Manuscripts and Rare Books of the Library of the Hungarian Academy of Sciences keeps three Mongolian manuscripts not published during Bálint's lifetime under the following titles and shelf numbers:

Nyugati mongol (Kálmike) szövegek. (184 pages), Nr.: M. Nyelvtud. 4/109; [Western Mongolian (Kalmyk) texts].

Bálint Gábor: Keleti mongol (khalkha) sqüvegek. (88 pages), Nr.: Ms1379/2; [Bálint, Gábor: Eastern Mongolian (Khalkha) texts].

A Romanized Grammar of the East- and West-Mongolian Languages. with popular Chrestomat[h]ies of both dialects. ... (222 pages), Nr.1: 81 szám, Nr.2: Ms 1379/1.1

Bálint did not publish his invaluable materials. When he finished the fair copy of the transcription of his field records, he was already on quite hostile terms with the leading scholars of the epoch and was in fact unacceptable and unwelcome in the scholarly spheres. So he did not succeed in finishing and issuing his material. In fact only the manuscript of the Grammar can be considered to be an entirely completed one. The manuscripts of the two text corpora of field records contain only the transcription without any explanation, analysis or translation. But the Chrestomathy part of the Grammar includes many specimens of Khalkha and some of the Kalmyk texts as well in a simplified transcription and in Bálint's English translation. $^{2}$

I started to study Bálint's legacy concerning the Mongolian languages more than ten years ago, but I came to publishing some parts of it only during the last five years. Hitherto I have studied in detail and published the Kalmyk records: Nyugati mongol (Kálmik) szövegek. [Western Mongolian (Kalmyk) texts] (hereafter

\footnotetext{
1 The entire title of the Grammar is: A Romanized Grammar of the East-and West-Mongolian Languages. With popular Chrestomaties [sicl] of both Dialects. Containing alliterative Folk-Songs, Anecdotes, Conversations, Fables, Proverbs, Prayers, Letters, Writs and the Description of the Characteristical Usages and Housekeeping of the Mongolians; every piece with faithful Translation, by Professor G. Bálint of S zentkatolna.

2 While working on the Kalmyk records, I consulted Bálint's translation, and if I thought it to be relevant, I included his proposals of interpretation of particular words and expressions into my translation.
} 
Kalmyke records) and his comparative grammar entitled: A Romanized Grammar of the East- and West-Mongolian Languages. with popular Chrestomat [h]ies of both dialects. ... (hereafter: Grammar). Regarding the Grammar, I issued it with a detailed introduction offering a wider context to his systematised grammatical observations by enlightening Bálint's endeavour of researching the Turkic and Mongolian vernacular, his intentions to seek the languages possibly related to Hungarian and emphasizing the values of his comparative grammar of vernacular Mongolian languages. The Kalmyk manuscript contains various genre groups of folkloric and ethnographic sample texts in addition some dialogues of everyday situations and some official letters as examples of vernacular and written language usage. The Kalmyk records I have published using the text-philological approach and analysing the particular genre groups in a wider context of sources on the Kalmyks (starting from Pallas'3 travelogue up to the present-day systematised studies ${ }^{4}$. The throughout comparative investigation of Bálint's Kalmyk records testify their linguistic and cultural uniqueness on the one hand, but on the other hand, numerous phenomena noted down by Bálint also appear in that time and also later sources, demonstrating their continuous existence among the Kalmyks.

I have worked with Bálint's third manuscript: Bálint Gábor: Keleti mongol (khalkha) szövegek. [Bálint, Gábor: Eastern Mongolian (Khalkha) texts] (hereafter Khalkha records) and issued particular texts and text groups analysing them from a specific point of view. One of the most unique texts of the Khalkha corpus is a Lama's narrative on the advent of Mongolian Buddhism, entitled: Cinggis bogdo xāne xara depterèn dotoräs yaryakson uge (Khalkha Cingis bogd xänì xar dewtrès gargasan üg) "Saying taken from the Black Book of the Holy Chingis Khan". I put this text into the context of the religious identity of $19^{\text {th }}$ century Mongols. Another text group I paid special attention to is the riddle corpus in the Khalkha records. I tried to compare each items in the context of the scarce coeval materials (M. A. Castrén ${ }^{6}$ ) and text corpora recorded later (Kotwicz, Ramstedt, Bukšan and Macga, Kara etc.). ${ }^{7}$ But apart from these few publications the thorough elaboration and analysis of Khalkha records is still ahead of me.

As I have already discussed Bálint's life, fieldwork methods and activity in Hungarian and international scholarly life, ${ }^{8}$ here I will not go into the details. I will only refer to the most essential events if it is necessary for the better understanding.

\footnotetext{
${ }^{3}$ Pallas $1776,1801$.

${ }^{4}$ Cf. the Bibliography of Birtalan 2011.

${ }^{5}$ An analysis of the text from point of view of religious identity: Birtalan 2012.

${ }^{6}$ Castrén 1857.

${ }^{7}$ Котвич 1972, Ramstedt; Halén 1974, Букшан, Б.; Мацга, И. 1960, Kara 1987.

${ }^{8}$ Birtalan 2014.
} 


\section{The linguistic value of the first large text-corpora of Vernacular Mongolian (Kalmyk and Khalkha)}

\subsection{The Kalmyk records}

Gábor Bálint of Szentkatolna being attracted by that time theories about the Hungarian Urbeimat and the ideas about the affinity of the Hungarian language undertook the assignment of the Hungarian Academy of Sciences and started his first field research in 1871 among the people speaking one of the Altaic language community, first the language of the Christianised Kazan Tatars. ${ }^{9}$

Bálint's main endeavour was to record "the purest folk tongue" that is, the sounding language, and the real vernacular. For this purpose he visited several schools in Astrakhan and recorded the Kalmyk folk tongue (1871 September 1872 May). Further he travelled through Siberia and became acquainted with some of the Buryat dialects. Nonetheless, he did not publish a comprehensive Buryat material on the basis of his records or experiences. But he published a Buryat grammar on the basis of a Christian catechism written in Buryat language by Boldonov. ${ }^{10}$ His Buryat grammar, issued during his lifetime ${ }^{11}$ confirms his deep knowledge about the structure and the grammar of Mongolian languages.

In 1873 he visited Urga and recorded a variant of Khalkha from a few informants only, first of all from a "black" (married) Lama. Yondonjamc (in Bálint's transcription Yanden Dsamcza). The wandering Lama became his language tutor and Bálint recorded from him first words, expressions, sentences, then ethnographic and folklore texts.

"During 155 days I did nothing else than writing down phonetically all things my lama or other persons called by him to me were able to dictate to me. I read the whole fable of Geser Khān with my lama and transcribed it in the spoken language. I must remark that my lama was no literator [sic!] but cleaverer [sic!] and more experienced than many of the learned ones.".12

Even if there are valuable early records on the Kalmyk vernacular, ${ }^{13}$ the first scientifically systematised description is Bálint's one. To some extent Rahmn's material ${ }^{14}$ can be paralleled with Bálint's Grammar. During his field research Bálint concentrated his attention on the vernacular and tried to record the real spoken form of the language. However, besides praising its value, I would like to draw attention to some minor problematic points of the otherwise excellent transcription. Namely the transcription of the texts does not reflect entirely all peculiarities

\footnotetext{
${ }^{9}$ Berta 1988.

10 Болдоновъ 1862.

11 Bálint 1877.

12 Birtalan 2009, p. 5.

${ }^{13}$ Doerfer 1965.

${ }^{14}$ Svantesson 2009a and 2009b.
} 
of the vernacular. On the basis of his previous linguistic studies Bálint was able to work out a fairly proper transcription system appropriate for recording the colloquial speech. Nonetheless some features of the written language are still present in it.

This dichotomous nature of his otherwise meticulously prepared system lies in all probability in the working method he elaborated for recording. His special method of collecting data among the Kalmyks can be easily restored on the basis of his notes and letters: first he asked his informants (first of all students and teachers of the secondary school and foster home he mainly worked with) to write down texts (folklore texts, and free talks, narratives about ethnographic topics) in written Oirat. On the basis of his remarks he mastered written Oirat quite well.

"After the folk songs followed the recording of tales with more difficult [syntactic] structure. These [tales] were written down in Kalmyk script by young Kalmyks from various tribes, some of them attended the secondary school, some the surgical school, and others the elementary school and were considered to be good story-tellers. These tales written down in Kalmyk script were repeated sentence by sentence for me by my instructor according to the people's pronunciation. In this way we prepared the transcription that I read out to him and corrected [the parts] in instances I had heard improperly. The grammatical analysis and the interpretation of the tales followed thereafter. My tale collection prepared this way contains fifteen shorter and longer folk tales written down with Kalmyk letters and in an abbreviated Hungarian transcription. All the texts recorded from the Kalmyk tongue are transcribed in both ways [i. e. in Kalmyk script and in translation]." 15

Bálint mentioned in his Report written to the Hungarian Academy of Sciences that the next step in his working method was to ask his informants to read the texts aloud and following the informants' pronunciation he transcribed the sounding texts. As some features of written Oirat still remained in the sounding texts, this makes us conclude that - while dictating the folklore texts and ethnographic narratives - his informants were not able to free themselves from the written version and in all probability inserted sounds into the spoken phonemic context that only occur in written Oirat if it is read letter by letter.

In Bálint's Kalmyk texts the influence of the written version of the sounding text is clearly visible in the transcription of the letter $b$, which is always transcribed as $b$ in the Grammar, while it often sounds as $w$ in spoken idioms. Although Bálint

\footnotetext{
15 "A dalok gyüjtését követte a nehezebb szerkezetü népmeséké, melyeket részint a gymnasiumba, részint a sebészeti tanodába, részint pedig az elemi iskolába járó és jó mesélőknek tartott, különbözô törzsü, fiatal khalymikok irtak össze khálymik írással. Ezen khálymik irásu meséket tanitóm a népkiejtés szerént nekem mondatolta és igy láttuk el átirással; ezen átirást azután én fölolvastam és a netán roszul hallottakat kijavitók, erre következett a mese nyelvtani fejtegetése és értelmezése. Az igy eszközölt mesegyüjteményem 15 hosszabb és rövidebb népmesét tartalmaz khalymik betükkel és röviditett magyaros átirással. A khalymik nyelvből gyüjtött anyag mind ilyen kettős írásu.” The text is given in Bálint's orthography. Bálint 1875, 12. Unfortunately, material written in Kalmyk script has not been discovered in Bálint's manuscript heritage.
} 
Ágnes Birtalan

mentioned how this letter must be pronounced, he consistently writes $b$ in his transcription, which cannot be taken as an effort to indicate the $b$ phoneme instead of its allophones, since he distinguishes several allophones in other cases. Bálint followed the particularity of the written forms in indicating the sound $b$ also in the positions (middle or end of word) where it was already spirantised in spoken Oirat and Kalmyk: Bálint arban yurbun, Kalm. arwn yurwn, W.Oir., Mong. arban yurban, Khal. arwan gurwan "thirteen", Bálint köbün, Kalm. köwün, W.Oir. köböün, Khal. xü, xӧw $\bar{u} n$ "son".

A distinguishing marker of the Kalmyk language among the Mongolian languages and dialects is the strong reduction of vowels in non-initial positions, which can be indicated simply by omitting the vowel that is represented in other Mongolian languages. In such cases Bálint often inserted an $e$, in the position of a schwa, e. g. Bálint ämek, Kalm. ämg, cf. Mong. ayimay, Khal. aimag "province” marked by Ramstedt with schwa: $\bar{a} m^{o} g$ ). The schwa is indicated with an $i$ in words having an $i$ in the first or second syllable: Bálint xal'imik, Kalm. xal'mg, xalimg, W.Oir. qalimay "Kalmyk".

Another important specificity of Bálint's system is that he indicated diphthongs in his texts. The Oirat dialects and Kalmyk lack the primary diphthongs represented in written Mongolian and written Oirat - and became monophthongised, resulting in a long vowel instead of the diphthong (in non-initial position the long vowels are shortened and sound like short ones): Bálint eime, Kalm. im, Ramstedt im, W.Oir. eyimi, eyimü, cf. Mong. eyimü, Khal. im "this kind".

These few examples clearly show the dichotomy of Bálint's transcription system rooted in his recording method. He first asked his informants to write down their texts in Oirat script and then requested them to read them in their own dialect. The presence of $e$ in the positions of the shwa in non-initial syllables, as a kind of overshort schwa-like vowel and the use of diphthongs in positions where the Kalmyk spoken tongue has long vowels are the traces of the written language.

\subsection{The Khalkha records}

As the complex analysis of the Khalkha texts is still in process, here I can show only some striking linguistic features of the Khalkha records. On the basis of the hitherto analysed texts I can only repeat what Professor György Kara has already emphasised, that a good number of the texts reflect Western-Khalkha phonetic features. ${ }^{16}$

The most salient Western-Mongolian (and Western Khalkha) ${ }^{17}$ phonetic marker is the use of the $k$ instead of $x$ in words with palatal vowels in numerous cases,

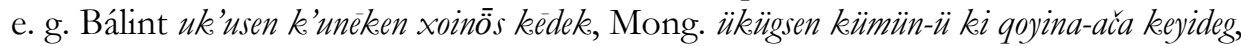
Khal. üxsen xünì xoinōs xìdeg, Oir. üksn künē xönös kìdg "[rituals] carried out for a

\footnotetext{
16 Kara 1962, 163.

17 In detail cf. Bese 1964.
} 
deceased". Another example of Western Khalkha is the lack of labial harmony, e. g. Bálint dotrās, Mong. dotor-ǎ̀a, Khal. dotrōs, Oir. dotrās "from inside, from among". Kara presumed that the main informant, a 45-year-old monk, was of Western-Khalkha origin. ${ }^{18}$ The future careful analysis of the texts might shed light on the dialectal features more appropriately. Bálint mentioned in his diary that his Lama-tutor was illiterate (it means he could read and write only in Tibetan and not in Mongolian), so he could not write and read the texts for Bálint, as the Kalmyks did. In this case the appearance of the written forms can be excluded.

"My Lama tutor called Yondonjamc had little to do. Well-known for his fluency in speaking, he could not write in Mongolian but only in Tibetan, for the Mongolian clergy find it beyond them to write, or even speak, in the language of their native folk. Money however loosened his tongue, and I was glad that he had not been concerned with anything else but the sacred Tibetan language and writs, for in this way he did not know the language of the Mongolian religious books which is rather well-known through Kowalewski's dictionary and could teach me the vernacular.

Moving next to the Russian consulate, this lama could visit me twice a day upon my request." 19

\section{Evaluation of the text-corpora as sources of that time ethnography, folklore and religious views of Kalmyks and Khalkhas}

Besides the sentence types of dialogues in both collections the most extensive part of the texts comprise the folklore material of various genres and the ethnographic narratives on various topics of nomadic way of life. The Khalkha collection also contains important narratives on Buddhism. On the basis of his working methodology and his letters to his mentors and fellows Bálint seemed not to be a "real" field researcher. He rather stayed in cities (in Kazan, Astrakhan and Urga) and worked with a limited group of informants (school boys, teachers and their relatives in Astrakhan and with a Lama and his few fellows in Urga) instead of going to the field and seeking for more herdsmen and peasants, etc. But this fact does not devaluate his immense achievements in studying the vernacular and recording the first information about vernacular (folk) culture in the native tongue; however, it demonstrates why the contents of his records offer a limited data in some respects. Examining his ethnographic material in the context of later field research issues Bálint's data are correct, and if the informant seemed "to fail", Bálint himself questioned his reliability. ${ }^{20}$

\footnotetext{
18 In detail cf. Birtalan 2012.

${ }^{19}$ Bálint 1875, 14.

20 "As among the Kalmyks he was interested in collecting folk songs, in his Report he remarked with lenient irony that his lama teacher started to create song himself and that was why he looked for
} 
Concerning the subjects of the Ethnographica, Bálint tried to create meticulously the context of vernacular culture for the spoken language material. He came from Transylvania and was acquainted with the Hungarian and Székely folk culture, so he could correlate his field experience among nomadic people with his native milieu experienced from his childhood. However, his main informants' knowledge was limited because of various reasons, the Kalmyks were mostly young (cf. their simple language usage), his Lama informant tried to explain the phenomena of Mongolian Buddhism - as he comprehended it from the periphery of the clergy (from the viewpoint of a half lay, half clerical person).

Nonetheless Bálint was able to build the image of lay and religious Mongols with the help of his informants' material - and a lay Mongol's life and vernacular culture is remarkably reflected in the Kalmyk and Mongol Ethnographica. ${ }^{21}$

\section{Concluding remarks}

Here I would like to point out the place of Bálint's records in the international Mongolian studies. Bálint collected two large sets of the spoken Kalmyk and Khalkha idioms and included some sample texts of his collections in the Grammar. His examples of the vernacular and particularly the fables, songs and other genres constitute the first attempt to introduce a Mongolian dialectal spoken idiom and a folklore material. Unfortunately these valuable texts were not published during Bálint's time soon after their collection. In his summarising article on Mongolian studies Bernhard Jülg highly evaluates ${ }^{22}$ A. Pozdneev's folksong collection, ${ }^{23}$ transcribed in a system based on the Cyrillic alphabet rendering the spoken forms of the language ${ }^{24}$ as the first bulky database in this respect. If Bálint's collections had been published according to his plans, that is, right after his arrival from his field research trip, his material would have earned him the fame for being the first of its kind, and an example for further editions.

Concerning the linguistic value of Bálint's records:

1. The 187-page Kalmyk and the 88-page Khalkha manuscripts can be considered as the first larger corpora of vernacular Kalmyk and Khalkha.

other informants (e. g. Lusīn Dorǰ, in his transcription Lusin Dords) to record folk songs.” (Birtalan 2009, XV, on the basis of Bálint Gábor jelentése p. 14).

21 The detailed content of the ethnographic narratives and folklore texts, cf. Khalkha texts: Birtalan 2009, 141-178, Kalmyk texts: Birtalan 2009, 179-221, Birtalan 2011, 17-19 and Birtalan 2015.

22 "In conclusion, I must call special attention to the frequently quoted grand work of A. Pozdnjejew, who was the first to introduce us popular literature of the Mongols." Jülg 1882, 53, 65.

23 Позднъев 1880.

24 "The Russian transcription is especially valuable as giving us, for the first time, an exact notion on the deviation of the present pronunciation from the original alphabet as determined by the written characters." Jülg 1882, 65. 
2. As the transcription of the texts is fairly good and accurate, these texts are proper for further linguistic research and the research of the $19^{\text {th }}$ century cultural context of the languages.

3. As the texts were dictated by informants with different background and probably by speakers of various dialects, further research might shed light on the possible dialectal differences of particular texts, too.

\section{References}

[Bálint, G.] 1875, Bálint Gábor Jelentése Oroszország- és Ázsiában tett utazásáról és nyelvészeti tanulmányairól. Melléklet öt khálymik dano hangjegye, Értekezések a Magyar Tudományos Akadémia Nyelv-és Széptudományi Osz̨tálya köréböl. IV (1875), 1-19. [Gábor Bálint's Report on his Journey in Russia and Asia and on his Linguistic Studies. With Notes of Five Kalmyk Songs. In: Treatises from the Department of Linguistics and Aesthetics of the Hungarian Academy of the Sciences] Reprinted by Kara 1975.

Bálint, G. 1877, Az éjszaki burját-mongol nyelvjárás rövid ismertetése, Nyelvtudományi Közlemények XIII (1877), 169-248. [Brief Description of the Northern Buryat-Mongol Dialect].

Berta, Á. 1988, Wolgatatarische Dialektstudien. Textkritische Neuausgabe der Originalsammlung von G. Bálint 1875-76 (Keleti Tanulmányok - Oriental Studies). Magyar Tudományos Akadémia Könyvtára, Budapest.

Bese, L. 1964, Two Western Khalkha Tales, AOH XVII (1964), 49-67.

Birtalan, Á. (ed.) 2009, Gábor Bálint of Szentkatolna, A Romanized Grammar of the Eastand West-Mongolian Languages. With popular Chrestomathies of both Dialects.

(Budapest Oriental Reprints: Series B 3). Library of the Hungarian Academy of Sciences - Csoma de Körös Society, Budapest.

Birtalan, Á. 2011, Kalmyk Folklore and Folk Culture in the mid-19th Century. Philological Studies on the Basis of Gábor Bálint of S zentkatolna's Kalmyk. Texts. (Oriental Studies 15). Library of the Hungarian Academy of Sciences, Budapest - Kalmyk Institute of Humanitarian Studies of the Russian Academy of Sciences, Elista.

Birtalan, Á. 2012, The Black Book of the Holy Chingis Khan: Remarks on a 19th Century Mongolian Folklore Source, Northeast Asian Studies (Tohoku University) 16 (2012), 245-259. On the Internet:

http://ir.library.tohoku.ac.jp/re/bitstream/10097/53696/1/1343-9332-201216-245.pdf

Birtalan, Á. 2014, Gábor Bálint of Szentkatolna (1844-1913) and Władysław Kotwicz (1872-1944) on the Kalmyk Language, RO LXVII (2014), 1, 55-75. 
Birtalan, Á. 2015, Kalmyk and Khalkha Ethnographica in Gábor Bálint of Szentkatolna's Manuscripts (1871-1873), AOH 68/3 (2015), 253-267.

Болдоновъ, Н. [Ш.] 1862, Аайда-дэлхэйн ушир (О мірозданіи). Тип. штаба войск восточной Сибири, Иркутскъ.

Букшан, Б.; Мацга, И. 1960, Хальмг Үлгрммуд болн тәљлвртә туульс. Хальмг АССР-ин дегтр haphач, Элст [Kalmyk Proverbs and Riddles].

Castrén, M. A. 1857, Versuch einer burjätischen Sprachlehre, nebst kurzem

Wörterverzeichnis, (Nordische Reisen und Forschungen von Dr. M. Alexander Castrén 10 ed. Schiefner, Anton). Kaiserliche Akademie der Wissenschaften, St. Petersburg.

Doerfer, G. 1965, Ältere westeuropäische Quellen zur kalmückischen Sprachgeschichte (Witsen 1692 bis Zwick 1827). (Asiatische Forschungen 18). Otto Harrassowitz, Wiesbaden.

Jülg, B. 1882, On the Present State of Mongolian Researches, Journal of the Royal Asiatic Society. (New Series) XIV (1882), I, 42-65.

Кара, Г. 1962, О неизданных монгольских текстах Г. Балинта, Народы Азии и Африки 1. (1962), 161-164.

Kara, Gy. 1973, Bálint Gábor keleti levelei. Jelentése Oroszország-és Ázsiában tett utazásáról. Értekezése a mandsuk szertartásos könyvéröl. Kőrösi Csoma Társaság, Budapest [Gábor Bálint's Eastern Letters. His Report on his Journey in Russia and Asia and on his Linguistic Studies. His Treatise on the Ritual Book of the Manchus].

Kara, G. 1987, Mongol Uriankhai Riddles, AOH XLI (1987), 15-39.

Котвич, В. А. 1972, Калмыцкие загадки и пословиць. Каммыцкое книжное издательство, Элиста.

Pallas, P. S. 1776, 1801, Sam[m]lungen historischer Nachrichten über die mongolischen Völkerschaften I-II, Kaiserliche Akademie der Wissenschaften, St. Petersburg.

Позднъев, А. 1880, Образуьг народной литературь монгольскихъ племенъ. Народныля пғсни монголовъ. Типографія Императорской Академіи Наукь, С.Петербургъ.

Ramstedt, G. J.; Halén, H. 1974, Nordmongolische Volksdichtung II. (MSFOu 156). Suomalais-Ugrilainen Seura, Helsinki.

Svantesson, J.-O. 2009a, Cornelius Rahmn's Kalmuck Grammar, Turkic Languages 13, (2009), 97-140.

Svantesson, J.-O. 2009b, Cornelius Rahmn and his Work on the Kalmuck Language, Northeast Asian Studies 13, (2009), 111-126. 


\section{Illustrations}

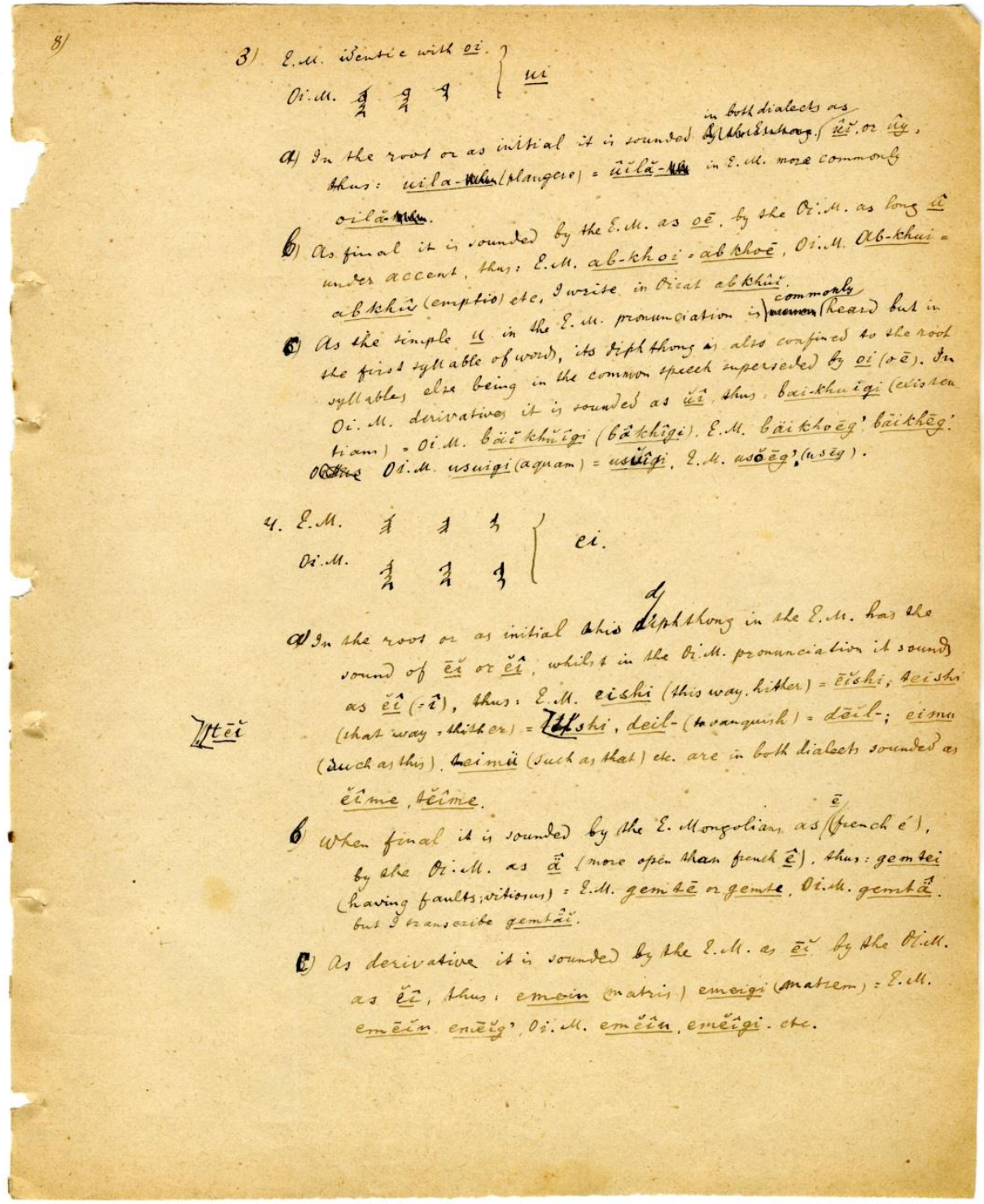

Figure 1: One page from Bálint's Grammar: instructions on the writing and pronunciation of $u i$ and ei diphthongs. (Grammar p. 8., Birtalan 2009 p. 23) 
$5^{2}$

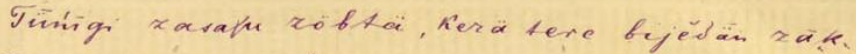

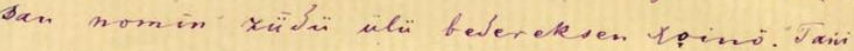

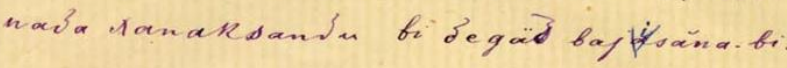

$$
\begin{aligned}
& \text { Iivebitkěi mom. }
\end{aligned}
$$

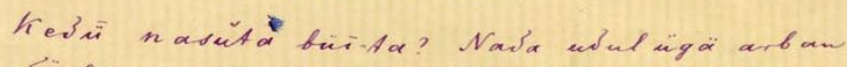

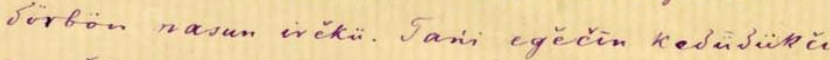

$$
\begin{aligned}
& \text { nasinis che büi? Jere ojo ar ban tabin / Jabain. }
\end{aligned}
$$

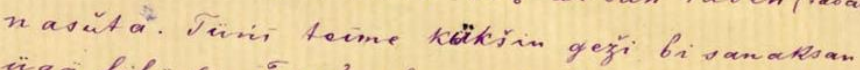

$$
\begin{aligned}
& \text { ïga biläbi Tanble basa ala. S̈̈ baìnu-jü? } \\
& \text { Tana, tere najasu yur bun nasum bai bolsok. } \\
& \text { amun jetie ata baibet boliza? Baina, tere }
\end{aligned}
$$

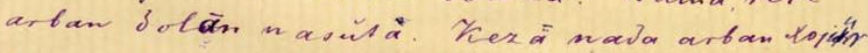

$$
\begin{aligned}
& \text { naven ireksen cantu bi gimniëre jü ojfu mör } \\
& \text { bi. Kerägaisi waran tani } 3 \ddot{i} \text { surpalibu büi? } \\
& \text { Dere tendä jeisen nascitordan oböla. Eime } \\
& \text { nasuntan etelèz" surputi surwkean Jegad } \\
& \text { arbavuteć nom. } 0009
\end{aligned}
$$

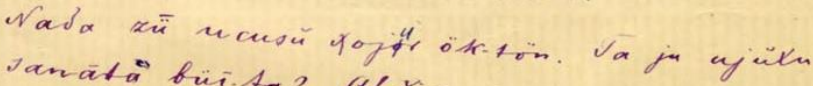

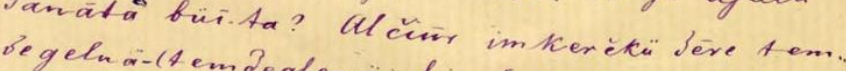

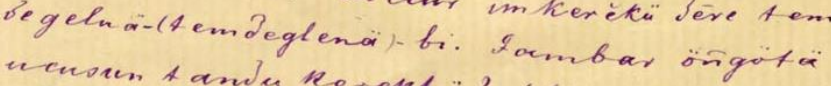

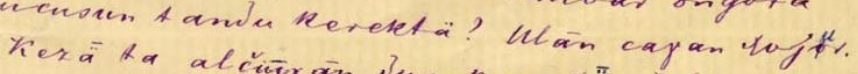

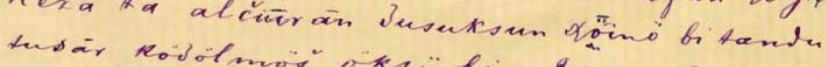

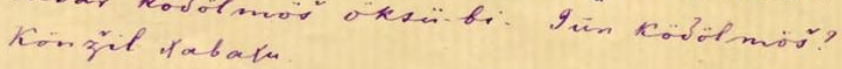

Figure 2: One page from Bálint's Kalmyk records: examples from everyday Kalmyk conversations. (Kalmyk records p. 1., Birtalan 2011 p. 190) 


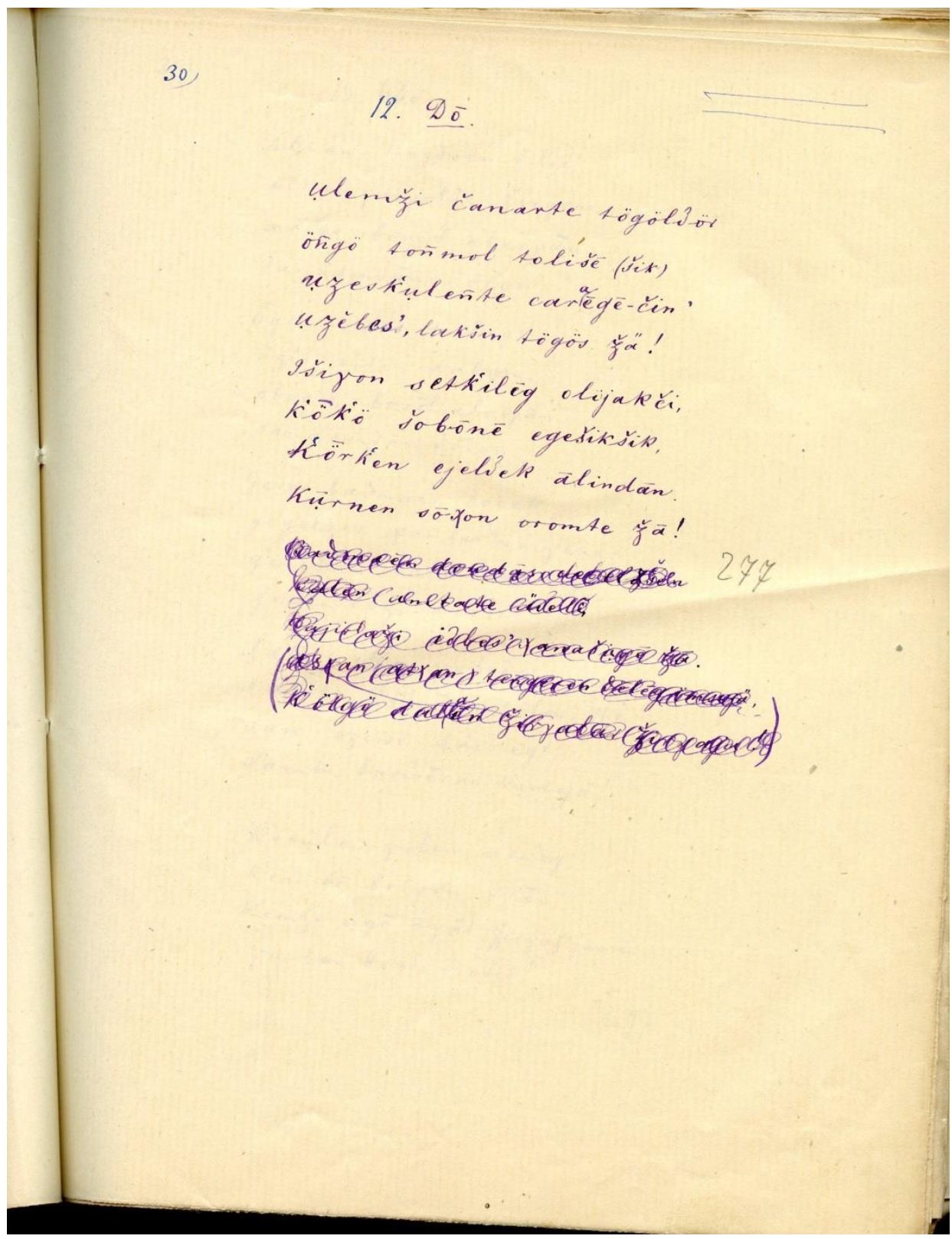

Figure 3. One page from Bálint's Khalkha records: the song No. 12. Probably the earliest version of Ülem̌̄in čanar in vernacular (Western-)Khalkha. (Khalkha records p. 30) 



\title{
News on manuscripts of Rabghūzī’s Qịsașu 1-Anbiyāa
}

\author{
Hendrik Boeschoten (Johannes Gutenberg-Universität Mainz)
}

\section{The Work}

The judge Nāșir ad-Dīn Rabghūzị from Khwarezm wrote his Stories of the Prophets (Qișas al-Anbiyä) in the years 1310/1 A.D. It was the first version in this genre in a Turkic language and has remained the most famous one ever since. The brand of Eastern Turkic Rabghūzi wrote in was the Khwarezmian Turkic literary language developing after the Mongol invasion. This variety marked the transition from Karakhanid Turkic in use in Eastern Turkestan from around the year 1000 A.D. onward to the diffuse conglomerate of written varieties known as Chaghatay. In other words, as put by Eckmann (1959), it can be considered the second stage in the development of a "Centralasiatic-Islamic Literary Turkic" following Karakhanid-Turkic.

The work is of great importance both as the most voluminous prose text in a written variety few sources for which have been preserved, and because of its great variation of different stylistic levels: verses from the Qur'ān with Turkic translations and exegetic material, as well as narratives from all kind of sources and poems of a rather good quality. It has remained the most popular work written in Eastern Turkic up to our days; copies of it were made well into the 20th century (see Jarring 1980).

Apart from its value for historical linguistics, including the study of the impact Arabic had on written Turkic languages, the text is also an important source for the history of Islam in Central Asia, and for the study of its genre. 


\section{Research History}

In Russia and in the West the work first became known through the edition by Ilminskij (1859) (the "Kazan print"), several reprints of which were published. There appeared some early Russian translations of single stories (e. g., Melioranskij 1897 and Malov 1930). The treatise of Schinkewitsch (1926-7) on Rabghuzi's syntax still stands as one of the great achievements in Turkology. Schienkewitsch already based his work on the London manuscript kept in the British Museum (today: British Library), but a facsimile edition of the same manuscript was only published by Grønbech in 1948. In 1995 we edited Rabghūzî̀s Qișaṣ for the first time in transcription with an English translation with a group of colleagues (Boeschoten \& Vandamme 1995), and also several articles on different aspects of the work. Our edition was shortly afterwards followed by an independent one by Ata (1997), containing a transcription and a full word index. A new edition has been prepared by John O'Kane and myself that includes the material from additional manuscripts.

\section{Genre and sources}

Stories/Legends of the Prophets (Qịas al-Anbiya) is one of the main genres of the Islamic literary tradition. Essentially a version contains the Res gestae of the oldtestamentic prophets, Jesus and other men with a high religious status (Luqmān Hakīm, Alexander-Dhu 1-Qarnain).

Earlier basic Arabic versions were written by Tha ${ }^{\circledR}$ labī (11th c.; translations by Brinner and Busse) and Kisā’̄ (translated by Thackstone). A Persian version by a certain Ibrāhīm b. Manșūr b. Khalafan Nīshābūrī is mentioned by Rabghūzī himself. Ultimately much of the material in all the version are derived from Tabarîs History (d. 923); its Persian translation by Ba lamī (A.D. 963, translation by Zotenberg) was also influential. Qur'anic exegesis (Tafsìr) from various sources is taken into account; very prominent is the material from pre-islamic Semitic narratives (Isrā'iliyyāt:) mostly associated with the traditionalist Wahb ibn Munabbih.

Rabghūzî̀s version contains the following chapters: Introduction; Creation; Adam; Seth; Enoch; Noah; Hūd; Șālih; Abraham \& Lot; Jacob \& Joseph; Job; Shu aib (Jethro); Moses; David \& Solomon; Jonah; Elijah; George; Luqmān; Ezra [Jeremiah]; Zacharias; Jesus; [the disciples]; [The Tubba ; miscellaneous stories; Nebuchadnezzar; The origins of Judaism, Christianity, idiolatry and fire-worship]; Alexander-Dhū 1-Qarnain; The Seven Sleepers Muhammad, his companions and his family (the chapters in square brackets do not occur in the London manuscript, see below).

The inclusion of Muhammad and his family is an unusual feature for the genre; normally a Qișaș al-Anbiyā' runs up to Muḥammad's birth. 


\section{Manuscripts used for the edition}

ms.A = London, British Library. Addenda 7851, 15th century, 249 folia. Published in facsimile by Grønbech (1948). Along with a few bits and pieces elsewhere, some 19 folia are missing between folia 110 and 111.

ms.B = St. Petersburg, National Library (formerly: Public Library), ȚḤC. 71, early $16^{\text {th }}$ century. The order of the folia is in complete disarray. About $27 \%$ of the total text, including the beginning and the end, are missing.

$\mathrm{ms} . \mathrm{Ba}=\mathrm{Baku}$, Oriental Institute of the Oriental institute of the Academy of Sciences of Azerbaijan. B-1460, written in 1552. Partly in disarray. The beginning up to midway the Story of Salih, part of the Abraham-cycle and the final page are missing. Parts of the Muhammad-cycle are shortened or left out. The existence of the manuscript was not yet known to Hofman (1969); Haciyeva (1996) was the first to mention it. It is the oldest Turkic manuscript of the collection; I surmise that at the time it has escaped deportation to Sanktpeterburg only because of its relatively poor physical appearance.

ms.T $=$ Tehran, University Library. no. 2132M, of unclear date. Basically complete, but for some folios at the beginning and at the end that were added later; the final page is lacking altogether. Hofman (1969) mentions a manuscript in Tehran, but has no further information about it.

ms.C $=$ St. Petersburg, Oriental Institute of the Academy of Sciences no. C245, written around 1560. Some pages which had been lost were added later. The Muhammad-cycle is mostly left out.

ILM = Ilmin'skij, N., Qișaṣ al-Anbiyāda Ribāṭ Og̉ūzīniñ qāżīsi Burhān ad-Dīn og̉lii Nāṣir ad-Dīn taṣnīfi-dür. Kazan, 1290 (1873).

Of these manuscripts, those from Baku and Tehran had not been considered in our first edition; copies of them were acquired a few years ago. These manuscripts belong to the old layer of manuscripts - old meaning that they are from the 1617 th century, i. e. at least one and a half century after the original was written. There are many more manuscripts, but these are from the 18th century and later, with the exception of two manuscripts kept in Tashkent:

ms.Taš1 = Tashkent, Oriental Institute of the Academy of Sciences No. 10252, "end of the 14th century" (Menges, 1966). No beginning or end.

ms.Taš2 = Tashkent, Oriental Institute of the Academy of Sciences No. 1834, "not later than the beginning of the 15th century" (Menges, 1966).

At least one of these manuscripts (not made available to us) is deemed by some to be older than the ones we worked with, but the linguistic evidence reported by Menges (1966) shreds considerable doubt on that opinion. In ms.Taš1 we find haybat-liq 'awsome' (paralleled by haybat-lig in ms.A211r12 = ms.T343v2), clearly a later (Chaghataic) form; in ms.Taš1 yax ši 'good' generally replaces Kwarezmian

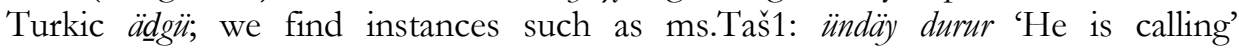


Hendrik Boeschoten

(ms.T171v4: ündäyü turur); another case is ms.Taš1: Siz bargan Teñrigä men häm barurmen 'I am also going to the God you are going to' ms.'Taš2: Siz baradurgan Teñrigä men häm barur-men ms.A (178r21): Siz bargan Tañrïga män häm barur-män ms.T (399r1): Siz bargan Tañrï-qa män mä barur-män.

\section{Archaisms in the Tehran ms.}

In contrast, the Tehran manuscript exhibits some archaic features even as compared to the passages in which some of the copyists at work in the London manuscript show certain archaic tendencies (cf. Boeschoten \& Vandamme 1986): Dative on /-QA/ (with few exceptions; also in some passages in the London manuscript); some nominal and verbal roots of the structure $(C) \mathrm{V}(=)$ that later disappeared, e. g., o 'pledge, security', (boyun) su= 'to offer' (the other manuscripts have og, (boyun) sun=); lexical items such as apañ 'if' (conditional conjunction) and qali kim 'like if'; frequent use of the $u=$ 'to be able' as a main verb: Bu sözkä umadï 'He couldn't endure these words' ( Bu sözgä tözmädi in ms.C); besides $u=$ as an auxiliary verb occurs also in the indicative, e. g. yaratu ugaymu? 'would he be able to create?' (as against yaratu bilgäy mü? In ms.C).

\section{Two redactions}

On the basis of the manuscripts at our disposal it becomes clear that two redactions are reflected in them. The larger one with additional stories between the Jesus-cycle and the Story of Dhūl-Qarnain (put in square brackets in the listing of the contents) occurs in ms.T, ms.C (that gives only scraps on Muhammad), and also in Ilmin'skij's edition (in which the Muhammad-cycle is reduced). The question now arises: Do the manuscripts from Tehran (ms.T) and from the Russian Academy (ms.C) contain additions, or were the sections deleted from the British library (ms.A), Russian National Library (ms.B) and Baku (ms.Ba) manuscripts? As yet this is impossible to decide; in our forthcoming edition that is primarily based on the London manuscript we added the relevant chapters from the Tehran manuscript. Of course it is also conceivable that even more material is included in other manuscripts. Just recently I saw a Türkmen translation (the original of which is not mentioned) that contains additional stories about Samuel and Daniel, placed both before the Story of David (Saryýew, 2004).

In any case the differences in content are up to a point matched by textual characteristics. Ms.B and ms.Ba more often than not agree in passages where the manuscripts overall diverge, and so do ms.T and ms.C to a lesser extent, but in that case there can be assumed a larger gap in time between their datings. The language features of ms.A are diffuse, because it is a convolute to which no less than seven scribes contributed (cf. Boeschoten \& Vandamme 1986). 


\section{Sloppiness of the London ms.}

This last circumstance is an indication that the London manuscript was produced at a copying shop. The haste with which the work was executed is reflected in numerous inconsistencies in the texts: words and whole passages are left out and are wrongly placed, personal endings in conversations are misplaced, etc. Because we drew upon the other manuscript for corrections, our edition often have a certain patchwork quality, as exemplified by the following two passages ${ }^{1}$ :

\section{Sample 1}

[210r4] Iman kältür-[5]-mädi-lär illa [az kim ärsä. "Sän bularnï mundag̉oq qodduñ ärsä, säniñ qul-larïnni] ${ }^{2}$ azdurgaylar, arïgsïz yaragsïzdïn özgä tugurmagay-lar.”

They didn't embrace the faith except for a few of them. [I said:] "If you leave them like this,they will lead your servants astray, and they will only give birth to wicked and useless people."

\section{Sample 2}

[44r1] Nämrudnïñ kökgä ağgàn sözläri

Qara quš-lar bala-[2]-larïn ektülädi-lär. Ulgardï ersä, kedin bir șanduq yondurdï; ikki qapuggluq, [3] biri üstün, biri astïn; säkkiz adaqlïg, törti üstün, törti astïn. Üstünki [4] adaqlarïnga qara qušlarnï bag̉latdï ${ }^{3}$ Özi yariqï yašiqui birlä oq [yasïn] ${ }^{4}$ alib bir ïnagï birlä [5] șanduq-ġa kirdi. Qušlar üstün ät-ni kördi-lär ersä, anï algalï uǵradi, učdï-[6]lar. Șanduq-nï havaga kötärdi-lär. Bir tün kün bardï-lar. Nämrud aydï: "Üstün qapuġnï ačgili; ne [7] körär-sän?" Ačdï, aydï: "Bayaqï teg körär-män.” Aydï: "Astïn qapugg-nї ačgiil; ne körär-sän?” Ačdi, [8] aydï: "Yer yüzini qamug kesäk körär-män.” Yänä bir kün tün bardï-lar. Aydï: "Üstün qapuġ-nï ačgili; [9] ne körär-sän?” Ačdï, aydï: "Yer[-din] ${ }^{6}$ kök nätäg körünsä, andagoq körünür," tedi. [Astïn qapugnï ačturdi. "Nä körünür," tesä, "qamug yer yüzi suw körünür," tedi.] "'Taqï käräk," teb yänä [10] bir tün kün bardï-lar...

\footnotetext{
${ }^{1}$ The transcription system has been simplified. I refer to our edition for a fuller presentation.

${ }^{2}$ Cf. ms.T (f.341v6-7).

${ }^{3}$ ILM, 86/7-8: üstünki șuruq-largaa et bağladï, șuruq-nïñ tübindä qara quš-larnï bag̀ladï.

${ }^{4}$ Ms.B (f.36r12) = ms.Ba (f.162v19); ms.T (f.59v8): oqï yasï birlä.

${ }^{5}$ Ms.T (f.59v10): bir tüni küni.

${ }^{6}$ Cf. ms.T (f.59v12), ms.C (f.28v29).

7 Additional in ms.T (f.59v12-13).
} 
On Nimrod's ascension to heaven

They fed young eagles. When the eagles were fully grown, Nimrod had a box made with two doors, one door on top and one underneath. And the box had eight legs, four on top and four below. Nimrod had the eagles chained to the legs on top. ${ }^{8}$ Then he took his breastplate and his helmet, his bow and arrow, and he entered the box with a companion. When the birds saw the meat above them, they tried to catch it and flew off, raising the box into the air. They travelled for one day and one night. Nimrod said: "Open the door on top. What do you see?" The companion opened it and said: "It looks as it usually does." Nimrod said: "Open the door below. What do you see?" He said: "I see the earth in one piece." Again they travelled for one day and one night. Nimrod said: "Open the door on top. What do you see?" He opened it and said: "The sky looks exactly as it does from earth." Nimrod had the door below opened and asked: "What's there to see?" The companion said: "The whole earth looks like water." Nimrod said: "We must go further", and they travelled for one more day and night.

\section{Conclusion}

Considering the somewhat messy state of the London manuscript, one may ask why we did not use the one manuscript as a basic text that is almost complete, overall more coherent and possible even older, i. e. the one from Tehran. The answer is manifold. First, we had the first edition available on which our second edition is based. This text and the translation still needed many corrections, and we present them in the new edition. Secondly, the narrative in the Tehran manuscript also is faulty in many places, and often the narrative as such deviates from the text in ms.A. So we stuck to ms.A as the basis for our edition, and left a possible edition of the Tehran manuscript (certainly a desideratum) to others.

\footnotetext{
${ }^{8}$ ILM is more explicit here: "Nimrod fastened meat on the poles on top and chained the eagles underneath the poles."
} 


\section{Bibliography}

Ata, A., Rabgûzî Kısasu'l-Enbiyâ. 2 vols. Ankara, 1997.

Boeschoten, H., "The Leningrad Manuscripts of Rabghuzi's Qisas," Türk Dilleri Arasturmaları (1991), pp. 47-79.

Boeschoten, H. \& J. O'Kane, Rabghüzì's Stories of the Prophets. 2 vols., Leiden, 2015. (second edition of Boeschoten \& Vandammme 1995).

Boeschoten, H. and M. Vandamme, "The different copyists in the London ms. of the Qișaș-i Rabghuzi," Proceedings of the First Seminar on Central Asian Studies. Utrecht, 1986, pp.177-183.

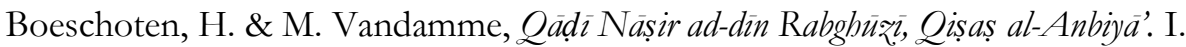
Text edition (with S. Tezcan); II. Translation (with J. O’Kane). Leiden, 1995.

Brinner, W. M., 'Arā'is al-mağālis or 'Lives of the Prophets' as recounted by Abū Isḥāq Aḥmad b. Muḥammad b. Ibrāhīm at-Ta $a^{e}$ labī. Leiden/Boston/Köln, 2002.

Busse, H., Islamische Erzählungen von Propheten und Gottesmännern. Qișaṣ alanbiyā oder 'Arā’is al-mağālis von Abū Isḥāq Aḥmad b. Muḥammad b. Ibrāhīm at- $\underline{-} a^{e}$ labī. Übersetzt und kommentiert von Heribert Busse. Wiesbaden, 2006.

Eckmann, J., "Das Chwarezmtürkische,” PhTF I, 1959, pp. 113-137.

Grønbech, K., Narrationes de Prophetis. Cod. Mus. Britt. Add 7851. Reproduced in facsimile. København, 1948.

Guillaume, A., The Life of Muhammad. Oxford, 1955.

Hacıyeva, N., Näsiräddin Räbğuzinin “Q1sasü-änbiya” äsärinin dili. Bakı, 1996.

Hofman, H., Turkish Literature. A Bio-Bibliographical Survey, Section III, part I, vol. 1-6. Utrecht, 1969.

Ilmin'skij, N., Qișaș al-Anbiyāda Ribāṭ Og̉ūzīniñ qāżīsi Burhān ad-Dīn og̣lï Nāṣir ad-Dīn taṣnîfi-dür. Kazan, 1290 (1873).

Jarring, G., Literary Texts from Kashgar. Lund, 1980.

Malov, S. E., "Musul'manskije skazanija o prorokax po Rabguzi," Zapiski Kollegii vostokovedov $\mathrm{V}$ (1930), pp.507-525.

Melioranskij, P. M., "Skazanie o proroke Salikhe v Kysasu l-enbiya Rabguzi," AlMuzaffaria. Sbornik statej u_cenikov pro_esora barona Viktoria Romanovica Rozena. St. Petersburg, 1897, pp. 279-308.

Menges, K.H, "Report on the second excursion to Taškent for research in Čayataj manuscripts,” CAJ 11 (1966) pp. 87-133. 
Nagel, T., Die Qișaṣ al-anbiyā'. Ein Beitrag zur arabischen Literaturgeschichte. Phil. Diss., Bonn, 1967.

Nagel, T., "Kịșaṣ al-Anbiyā'," EI, V, pp. 180-181.

an-Nīshābūrī, Ibrāhīm b. Manșūr b. Khalaf, Qiṣaṣ al-anbiyā'. Ed. Ḥ. Yaghmā̄ō. Tehran, 1961.

Saryýew, T. (red.), Kysasy Rabguzy (Kysasyl Enbyýa). Ašgabat, 2004.

Schinkewitsch, J., "Rabguzis Syntax," Mitteilungen des Seminars für Orientalische Sprachen zu Berlin, Zweite Abteilung, pp. 29-30, Berlin, 1926-27.

Aț-Ṭabarī, Abū Ja far Muhammad b. Jarīr, Mukhtașar ta'rīkh ar-rusul wa l-mulūk wa lkhulafä'. Edition: M. de Goeje (red.). Leiden, 1879-1901. Translation:

E. Yarshater (general editor). Albany/N.Y., 1985-.

at-Ta labī, 'Arä'is al-Majälis. Cairo, undated.

Thackston, W. M., The Tales of the Prophets of al-Kisā's. Translated from the Arabic with notes. Boston, 1978.

Zotenberg, H., Chronique de Abou Djafar-Mohammed-ben Djarir-ben-Yezid Tabari, traduite sur la version persane d'Abou Ali-Mohammed. 4 vols. Paris, 1867-74. Reprint Patis, 1958. 


\title{
The Making of the Pentaglot: Concepts, Data Structures and Tools
}

\author{
Oliver Corff (Berlin)
}

\section{Abstract}

The realization of the Pentaglot Project (Wuti qingwenjian), the modern critical edition $^{1}$ of the famous Qing Dynasty multi-lingual dictionary, required elaborated concepts covering fields as diverse and unrelated to Altaic studies as project management, data processing and formal logic. In light of the five languages comprised in the Pentaglot (namely Manju, Tibetan, Mongolian, Turki and Chinese), data encoding and representation become crucial for properly processing and visualizing lexical material. The scholarly requirements of critical editions were to be considered as well. The article sets the focus on the importance of fundamental working principles established at the very beginning of the project, and key components of open-source software will be introduced.

\footnotetext{
${ }^{1}$ Corff, Oliver, Kyoko Maezono, Wolfgang Lipp, Dorj Dorjpalam, Görööchin Gerelmaa, Aysima Mirsultan, Réka Stüber, Byambajav Töwshintögs and Xieyan Li ed. 2013/2014. Auf kaiserlichen Befebl erstelltes Manjurisches Wörterbuch in fünf Sprachen. Systematisch angeordneter Wortschatz auf Manjurisch, Tibetisch, Mongolisch, Turki und Chinesisch. Vollständige romanisierte und revidierte Ausgabe mit textkritischen Anmerkungen, deutschen Erläuterungen und Indizes. Wiesbaden: Harrassowitz.
} 


\section{Introduction}

The Pentaglot, a multi-lingual dictionary compiled around 1790 to 1794 (exact date unknown) during the last years of the reign of the Qianlong emperor, ist the final and most comprehensive work of a series of multi-lingual dictionaries which were developed over more than a century. The languages include (in order of the dictionary) Manju, Tibetan (lemmata in Tibetan script with two auxiliary notations in Manju, a very detailed transliteration as well as a transcription), Mongolian, Turki (lemmata in Arabic script with an auxiliary pronunciation guide in Manju, though not to be considered a systematic transcription), and Chinese. Unfortunately, this work was never printed, but three manuscripts survive of which two were reproduced in the 20th century. The Fengtian Ms. (first found in Shenyang) was photographed in 1912, the plates later reproduced in Japan, though the reproduction only saw limited circulation. The Chonghuagong-Ms. was reproduced in 1957 in Beijing and remains, to this day, the most widely circulated version of this text, and finally the London Ms., of which no reproductions have been made publicly available as of the date of this article. The three manuscripts share the same lexicon (except for a few minor differences) and the same arrangement of lemmata (again except for very few differences), yet differ widely in copy quality. Mistakes, errors and omissions are abundant in the Chonghuagong-Ms., yet the scribes paid fair attention to the execution of the writing. The Fengtian-Ms. shows less textual errors, but in many instances an astonishingly sloppy hand, leading to the assumption that the Chonghuagong-Ms. may have been a manuscript in an intermediary editing status, while the Fengtian-Ms. may have been intended as a working copy for the purpose of private consultation. The London Ms. is the complete opposite to the former two. Its calligraphy has been executed in superb quality on the finest paper, errors, be they spelling or lexical errors, are virtually completely purged, but nonetheless even this version did not yet seem fit to print as occasionally inserted small yellow slips of paper with suggestions for a different choice of words hint.

The magnitude of the Pentaglot dictionary can be outlined by a few figures. With 36 fascicles totalling more than 2,500 folia or around 5,000 pages, a total of 18,671 lemmata, each lemma being composed of five languages distributed over eight lines, employing four essentially different writing systems with three different directional orientations, the Pentaglot is a massive work well comparable in size and complexity with modern comprehensive dictionaries representing an effort which must have taken dozens of man-years to complete. Despite this impressive investment of brain and manpower, the Pentaglot was never printed and distributed.

In general, dictionaries of this era could be arranged in an alphabetical order if Manju was the dominant or only language, or otherwise an elaborated semantical classification system of entries was used, as in the case of the Pentaglot. No index allows direct access to any of the five languages; the only method of consulting the dictionary was to know the classification system by heart and browse through indi- 
vidual categories until the desired entry is found. The Pentaglot manuscripts do not even have a comprehensive table of contents. Only the London manuscript is readily available for autopsy; it displays the categories on the cover of each fascicle in Manju and Chinese.

The Pentaglot Project was the name chosen in the late 1990s for the endeavour to produce a fully romanized critical edition of this monument. A comprehensive index system for all languages was as much a desideratum as the careful correction of some of the most visible technical errors (e. g. mal-positioned Mongolian entries); in the course of progress, extensive notes were added to many entries, commenting on etymology, classification, textual errors and text sources. The Chinese material had to be accompanied by a reading aid (Hanyu Pinyin) in order to distinguish between different meanings of homographs, and a translation into a modern language was considered helpful as well. Given the inherent ambiguity of the Mongolian writing system, a Khalkha gloss was also added. A cross-referencing system combining the classification system of the main part (fasc. 1-32) and addenda (fasc. 33-36) was established, furthermore reproductions of the most interesting writing variants (and errors) were included as graphical representations. More than 15 years passed between the first experimental data collection and the publication of the critical edition in 2013 as well as five index volumes in 2014.

\section{Divide et impera}

\section{Division of labour between man and machine; division of labour between individual contributors}

With regard to the nature of the Pentaglot (being a dictionary, which, in turn is a linear representation of a tabular database with entries and fields), it was clear from the very beginning that any attempt to compile all entries of all languages into a single text was doomed to fail. Given 18,671 entries and 11 columns (eight columns of text + Mongolian Khalkha gloss + Chinese Pinyin + German translation), more than 205,000 (a fifth of a million, that is) entries would have to be typed, formatting information added, and so on, requiring the authors and typists to switch their focus of attention about half a million or well over a million times between text and computer system, depending on the number of walks through the complete material. Control of mental focus and proofreading would be impossible while the number of work-induced errors would be overwhelming.

The only way, then, was to analyse the Pentaglot and to treat it as a database, allowing to divide labour between humans, e. g. different persons working on different languages, and to divide labour between man and machine: after all, why should a human select a different typeface for all parts of all entries half a million times if a machine can be charged with this task, delivering an infinitely more reliable performance than a human at a fraction of the time required by a human, without ever complaining of physical or mental exhaustion? Even the work being done 
by humans could be simplified by the help of computers, breaking the processes down into simple, fail-safe steps, thus eliminating the risk of any operational distraction. Maintaining focus on a given task at a given time was considered a key factor of achieving editorial quality.

A very simple structure had to be designed which would allow co-authors to collaborate while being separated by time and geography. For every language, a simple, straight-forward text file was constructed, thus even eliminating the need for a common database software. Any text editor the individual author felt comfortable with was deemed fit for work.

A minimum of structural information had to be included in every text file in order to construct the proper relations between all files and lines, a simple line structure was set up. Every line, containing exactly one entry, consists of two parts: structural information and textual information. The structural information part consists of three fields: a unique reference number, a label indicating the type of entry, and an optional marker for the editorial status. Fields are separated by tab stops. The textual information part is split into three fields, all of them optional: the first or descriptive field containing the word form found in the Pentaglot Chonghuagong manuscript, the second or normative field containing a suggested normalized form, if applicable, and the third field containing a comment or note. All text fields are of variable length (which can be zero, representing an empty field) and are separated by semicolon. Occasionally, there are missing entries in the Pentaglot manuscripts and thus the first field can be empty. In this case, the second field contains the intended word. Two practical examples drawn from Manju and Tibetan (in Manju transcription) look as follows. The first line demonstrates how an error in the text is corrected, and the second line shows how a missing entry is completed.

0224.4.10 [lemma] ! yor seme;yur seme;BL, TB, Haneda, Hauer, ...

1445.4.40 [lemma] ! ;jajumet;PEK: Eintrag fehlt, vgl. BL.

Structural information: In this example, 0224.4.10 stands for the Manju entry (language code 10; the other language codes will be given below) in column 4 on page 0224 of the Beijing 1957 reproduction of the Chonghuagong manuscript. the entry type is [lemma], other entry types being [bu], [lei] etc., indicating chapter and section headings, and additional entry types for blank lines as some pages have less than four columns. The exclamation mark indicates the editorial status and signals that the entry is completed. A question mark would mark the entry as unfinished. Thus it becomes possible to quickly search for those entries which need reworking as the author simply places a question mark in this position. Accordingly, 1445.4.40 stands for the Tibetan entry in Manju transcription in column 4 of page 1445 of the Chonghuagong manuscript. 
Textual information: In the first example, the Chonghuagong Ms. reads yor seme, however by comparing all sources it becomes clear that yur seme is intended (the Manju diacritic for "u" is missing), hence the suggestion yur seme; finally, a reference to all consulted sources appears in the third column. In the second example, the empty space before the first semicolon indicates the absence of an entry at this position, while the second field provides the word which should go there, followed by a short comment. A regular line featuring neither suggested normalized form nor comment looks like this:

\subsubsection{0 [lemma] ! yar seme;}

Every text file had the same number of lines, 19892 to be exact: 4973 pages (Beijing 1957 reproduction) times 4 columns per page. There are eleven such files, one for Manju (xxxx.y.10), Tibetan proper (xxxx.y.20), Tibetan in Manju transliteration ( $x x x x . y .30)$, Tibetan in Manju transcription ( $x x x x . y .40)$, Mongolian (xxxx.y.50), Khalkha gloss (xxxx.y.55), Turki in Arabic script (xxxx.y.60), Turki in approximated Manju transcription ( $x x x x . y .70)$, Chinese (xxxx.y.80), Hanyu Pinyin $(x \times x x . y .85)$ and German translations ( $x \times x x . y .90)$.

A master file containing all page and column references of all manuscripts as well as the Chinese names of all sections and subsections served as organizational hub against which the eleven language files were linked like spokes of a wheel:

0003.15 卷一 天部。一类七则。天文类。第一。2r1/0002 2a1

This line describes the entry in column 1 of page 0003 of the Beijing 1957 reproduction. It is the fifth lemma of 18,671; it is found in the first fascicle (卷一) and is grouped in the first section of the astronomy category (天文类。第一) under the Heaven chapter (天部); this entry is located in the first column of the recto of the second folium of the London Ms., bearing the pencil mark 0002 added by an unknown writer in the year 1934; similarly, folium 2 of the Fengtian Ms. (both manuscripts are not always aligned, hence the need to supply separate folium numbers for each manuscript).

All information necessary to produce a printable typoscript with complete markup is contained in these two groups of files: one organizational file and eleven language files of identical structure. Pages are referenced by common page numbers, headings for the table of contents and page headers are provided by the various [bu] and [lei] type entries, formatting is controlled accordingly, and the comment columns of the textual information, if present, are converted into footnotes. No single human intervention is necessary for choosing the correct formatting markup if everything is set up properly. 
Thus, every contributor can work on a single file without ever risking to jeopardize the work of colleagues or the appearance of everything in combination; the contributor has neither need nor means to deal with formatting issues.

\title{
4 Making a Difference for Analytics and Representation
}

\author{
A match or not a match? Descriptive and normative word forms; Tibetan alphabet vs. Manju \\ transliteration; Turki word counts; showing everything
}

\subsection{Differences and Analytics}

The technical possibility to compare two data sets and thus calculating their difference is a simple but nonetheless powerful means to obtain and visualize findings. A few examples are given here. The Tibetan entry in 0478.2 of the Chonghuagong Ms. reads slob-rtags-bri, but the Manju transliteration reads sleb rd'aks bri and the transcription reads lebdakbiri. Obviously, the Tibetan vowel sign should indicate an " $\mathrm{e}$ " and not an "o" as the Manju lines suggest; the normative reading sleb-rtags-bri is confirmed by the other manuscripts. Literally hundreds of mistakes in the Tibetan fields were discovered by simple and automated comparison of the Tibetan text and transliteration fields.

An interesting challenge was found in the different word count of Turki in Arabic script and Turki in Manju transcription. Turki ay (engl. moon; one word) was rendered in Manju as a $i$ (two words), hence resolving a diphthong as an intra-word hiatus. A survey of the transcription revealed that there are several hiatus types in the Turki transcription which stand for certain Turki pronunciations in a very systematical manner; similarly, spelling variants could be identified and distinguished from simple copy errors. Take the Manju transcription kû́cikači (engl. sparrow) which occurs 170 times in exactly this form and only five times in different spellings (mostly varied diacritics); it is apparent that there is only one normative form. Other words appear regularly in two or three different spellings of similar frequency; here we cannot speak of errors but must accept the variation.

Comparisons or differences of data sets are also possible and feasible across languages. By matching identical parts of speech, e. g. Manju verbs (finite forms ending in $-m b i$ vs. Mongol -mui or -müi) it is possible to verify the correct match between Manju and Mongol. Take lemma 3006.4. Manju says hûfan, but Mongolian has suramui. Clearly, the Manju word is not a verb while the Mongolian word is a finite verb. The problem here is that the Mongolian scribe forgot the word which was intended in this position (xorsiyal should go here), shifting the following 14odd entries up by one column. 3007.1 is Manju surambi which should be matched by Mongolian suramui. The correct Mongolian entry order is restored by writing the word üsüd twice in 3009.4 (where we are indeed supposed to find bayuraǰ) and 
3010.1. This case was discovered by the following search (expressed in programming meta-language):

FOR (every line of Manju data and Mongol data) DO

IF Manju word ends in -mbi

AND Mongol word does NOT end in -mui or -müi

THEN print line

The numerous positional errors committed by the Mongolian scribes could be quickly and precisely identified in this way.

\subsection{Differences Made Visual}

\section{Automated typesetting of textual variations}

The same principle of comparing data sets in order to calculate their difference can be applied to the comparison of descriptive and normative data. Taking again the Tibetan example in position 0478.2 of the Chonghuagong Ms., slob-rtags-bri. The Tibetan data line (simplified for the sake of clarity) reads:

0478.2.20 [lemma]! slob-rtags-bri;sleb-rtags-bri;[...]

An automated difference between the descriptive data slob-rtags-bri and the normative data sleb-rtags-bri will find the same syllable count and highlight the first syllable of the two sets as different, generating a user-defined typesetting command for the following typesetting process:

$\backslash$ onedfrnt $\{$ slob $\}\{$ sleb $\}-$ rtags-bri

where the command \onedfrnt stands for "one element different" and takes two arguments, generating the following typesetting result:

slob/sleb-rtags-bri

saying: found slob, read sleb, followed by rtags-bri.

All approx. 15780 differences between descriptive and normative forms identified in the critical edition thus could be typeset in a uniform manner without requiring more attention from the contributors than simply putting the observed and the perceived form side by side. 


\section{$5 \quad$ Putting everything together}

\section{Combining structural metadata, textual data, and image data into one output}

In order to produce the complete critical edition, the above-mentioned master file containing the structural metadata and eleven language files form the basis. One additional file contains all those annotations which are not specific to one single language but refer to the whole lemma as such (e. g. the text source of its origin, notes about the meaning, cross-references between different entries or groups of entries, etc.). This file employs the same principle as the eleven language files: every note consists of two parts, namely a header and the note text proper. The header uses the same familiar xxxx.y format to identify the position, followed by the note text. All files are read by a custom-made utility program which produces the files from which the typesetting system generates the PDF output. Besides these input files where all language material and organizational information is merged into one common structure, the typesetting system uses additional files containing detailed formatting instructions, image files containing the reproductions of small portions of the Chonghuagong manuscript (in most cases images of single words), all fonts as well as a collection of approximately 1,000 user-defined Chinese characters for the careful reproduction of the Chinese text.

\subsection{Encoding Issues}

When work on the Pentaglot started in the late 1990s, Unicode was still a distant future at the horizon. While all other scripts in the Pentaglot could be represented by Latin translations, Chinese was the single exception. In the beginning, Big5 seemed to be the encoding of choice as it offered a greater choice of traditional characters than the GB2312 standard of the People's Republic of China. As soon however as editors with practical handling capabilities for Unicode material appeared, all material compiled so far was converted to Unicode. Still, not one single font is enough to fully represent all character varieties found in the Pentaglot manuscripts; characters from three or four fonts were helpful for a small number of varieties, but for the bulk of yitizi new characters had to be made as graphical representations. Some of those characters were later discovered to be included in the Unicode extensions A and B of the CJK block, but at that point it was considered safer for the technical production to stick with the chosen path of including individual yitizi as vector graphics.

The romanization of the Arabic alphabet was chosen in such a way that two possible outputs via two different conversion paths could be computer-generated from a single file. In this manner, a full convertability between the romanization in the critical edition and the original Arabic material is guaranteed. 


\subsection{Tool Box}

The following open-source software tools were used for the production process:

Vim ("vi improved", www.vim.org) is a line-oriented text editor available for the majority of operating systems. Besides the strict line orientation with optional line numbering, it features a powerful regular expression engine allowing complex search and replace operations. It also features the synchronized side-by-side display of files with automated highlighting of all differences, a feature extremely useful for tracking one's own editing history (by comparing older and younger versions of a file) or by tracking the work of two persons working on the same file.

The user interface of vim works without mouse, allowing the operator to keep the hands on the keyboard at all times; this ergonomical factor contributes significantly to a smaller error rate since switching between keyboard and mouse (as well as moving the focus of attention between hand, keyboard, mouse and screen) is not required.

All utility programs for analyzing data and generating output from combined files were written in Perl. Perl (found at www.cpan.org) is a high-level generalpurpose interpreted language also known as "Practical Extraction and Reporting Language", providing powerful text processing facilities.

Typesetting was done with XeLaTeX, a TeX-based typesetting engine using Unicode and supporting modern font technologies. Complete TeX/LaTeX installations for all major computing platforms can be found at www.ctan.org.

The image manipulation operations (automated cutting, resizing, etc.) of the 670-odd text example image files were done with the utilities contained in the Netpbm package (found at netpbm.sourceforge.net). The same package also was helpful in creating the 1,000-odd user-defined Chinese characters of writing variations ("yitizi") not found in the Unicode standard.

All these software tools have the common advantage of being freely and legally available. They are accompanied by extremely detailed documentation, and there is a huge community of experienced users in academia who voluntarily answer questions and contribute to solving individual problems.

\section{Summary}

From the very beginning, the Pentaglot Project required a carefully planned division of labour not only between individual contributors, but also between man and machine. All data files had to be organized in such a manner that every contributor could work independently of all others and ideally also independently of specific software requirements. A rigid separation was made between data and presentation. The data files do not contain any presentation (vulgo: formatting) information whereas the system used for formatting the output does not contain any data; it only processes them. The purpose of the rigid separation between the capabilities of man and machine is two-fold. One purpose is to alleviate the operator 
of the most mundane tasks by allowing to focus the attention on the data; the other purpose is to enhance the editorial quality by reducing the number of opportunities for introducing errors.

A formal analysis of the Pentaglot text reveals a logical organization of the material well suited for the transformation into a relational database; a hub-and-spoke concept was used for relating all languages files to a single master file the structural information of which is used for controlling the appearance of everything.

A very simple data comparison model essentially yielding differences between sets of similar data was used for a multitude of tasks: spelling errors within individual languages as well as errors across language pairs could be detected and identified in a comprehensive and exhaustive manner. The same comparison operation also produced the markup for the more than 15,000 individually annotated spelling variants and errors found in the text.

All software tools employed for producing the camera-ready copy of the critical edition of the Pentaglot are open-source tools accompanied by detailed documentation and supported by a broad user base familiar with the requirements of the academic community.

The most important goal of organizing the production process in the manner outlined above was to avoid frustration by allowing all contributors to concentrate on the text rather than forcing them to waste time and energy on an error-prone production process.

\section{Acknowledgments}

I like to thank my colleagues for their optimism and unbreakable spirit of endurance during so many years of patient labour against all odds and towards a goal that must have appeared so far away at too many moments in time. Working together over so many years was a wonderful experience! 


\title{
Chinese sources on the modern history of Xinjiang: reading the Kashi shi wenshi ziliao
}

\author{
Michael Dillon (Worksop)
}

This paper considers the value and significance of the Chinese language sources that were used in writing Xinjiang and the Expansion of Chinese Communist Power: Kashgar in the Twentieth Century. ${ }^{1}$ These sources are the Kashgar volumes in the wenshi ziliao 文史资料 (materials on culture and history) series that was published in the People's Republic of China from the 1980s onwards as an alternative to the monolithic official histories that had been the norm until then. As the articles in the wenshi ziliao series are based largely on individual recollections and oral testimonies, its use raises interesting and important questions on the reliability and value of this kind of material as a historical source. These books are only available in Chinese and no complete or even partial translations are available. Hard copies of the volumes are difficult to come by, as are many of the wenshi ziliao volumes for individual cities or counties, largely because of their classification as neibu ('restricted') which is discussed below. Selections for provinces or for China as a whole are more widely available. To read the Kashgar series it was necessary to use scanned versions which had been preserved and transmitted electronically. These volumes were not intended to be read outside China, hence the (neibu) classification: they were not therefore a type of soft power or propaganda designed to persuade the outside world of the inclusiveness of Chinese scholarly work, but a concession to

\footnotetext{
${ }^{1}$ Michael Dillon Xinjiang and the Expansion of Chinese Communist Power: Kashgar in the Twentieth Century London: Routledge 2014
} 
non-Party academics and an acknowledgment that scholars outside had voices and perspectives that should be heard. ${ }^{2}$

\section{Kashgar}

The oasis city of Kashgar (Kashi 喀什in Chinese), which lies on the edge of the Taklamakan Desert in the south-western part of Eastern Turkestan or Xinjiang has a strong claim to be dubbed the historical heart of Muslim Uyghur culture. ${ }^{3}$ In the twenty-first century it remains both the physical and the symbolic nucleus of traditional Uyghur society; this is in spite of the demolition of the picturesque and irreplaceable traditional buildings of the Old City in the face of desperate but futile opposition by its residents. The continuing existence of the city and its distinctive cultural features, which are preserved to some extent as a magnet for foreign tourists, are a constant reminder of the fact, uncomfortable for some, that the vast region of Xinjiang on the frontiers of the Chinese empire is a disputed territory in which some regions have an overwhelming non-Chinese, that is non-Han, majority.

The history of Kashgar and its region as revealed in Chinese-accounts has implications for our understanding of the way that southern Xinjiang was incorporated into the newly established People's Republic of China, and the impact of this policy of integration on the religion, society and culture of the Uyghurs since 1949. Although it is possible to generalise about the modern history of Xinjiang, it is important to bear in mind that the region as a whole occupies an area almost three times the size of France and is home to a widely scattered population. Communications between the different regions of Xinjiang are poor even today and were poorer still in the period under scrutiny in this paper. The north and south of the region are separated by the Taklamakan Desert, a western extension of the vast and inhospitable Gobi, and the consequence of this separation has, not surprisingly, resulted in distinctive cultures and historical traditions. Kashgar, tucked away in the south-western corner of Xinjiang, experienced the cultural clash with the forces of the CCP in a way that reflected not only its distinctive Islamic religious and cultural traditions but also its geographical isolation from the political and

\footnotetext{
2 Kashi shi wenshi ziliao 喀什市文史资料 (Cultural and Historical Materials on Kashgar City), Kashgar, no publisher, 1982-97 (12 volumes). There is a parallel series of volumes in the Uyghur language, Shinjang tarikh materiyalliri. (Xinjiang historical materials) published irregularly from 1980 onwards but to date it has not been possible to obtain a complete set of those relating to Kashgar and its region. A comparison between the Uyghur and Chinese editions would be illuminating.

3 The rival city of Khotan (Hetian 和田) which is over three hundred miles to the east of Kashgar on the fringes of the Taklamakan also has a distinguished history as a cultural and religious centre which can be traced back for centuries. In recent times it has been eclipsed by Kashgar in both size and influence. Yarkand, situated between the other two cities, also has a reputation as a religious centre.
} 
economic centres of China and its closeness to what was then India under the British Raj. ${ }^{4}$

It is the modern history of the city of Kashghar and its hinterland in southern Xinjiang, before and up to the occupation in 1949-50 by the People's Liberation Army - the armed forces of the Chinese Communist Party - that is the subject of Xinjiang and the Expansion of Chinese Communist Power: Kashgar in the Twentieth Century. The Chinese-language source material used as the basis, but not the only source for this book has been revealing and invaluable but often difficult to evaluate. Reading it has prompted questions on the use of such material for the study of non-Han areas of China, questions which almost certainly have implications for areas other than Kashgar and Xinjiang.

\section{Tibetan parallels}

This is certainly the case for Tibet and Melvyn Goldstein has drawn attention to Tibetan-language versions of these 'eyewitness written accounts', which were an important source for his standard works on modern Tibetan history and which, in his estimation, were notable for an 'impressive frankness'. That is a phrase that can also be applied to the Kashgar volumes of the wenshi ziliao in comparison with what was available previously. In the Tibetan case the cultural and historical materials represented a completely new source of data that had not been available previously to scholars. An Office of Cultural Historical Materials was established in Lhasa and former officials were given the opportunity to write their own narrative accounts of their experiences and were paid for their trouble. The result was nine volumes published between 1982 and 1986, mostly written in Tibetan by retired Tibetan officials; some articles were written in Chinese by former Chinese officials and were subsequently translated into Tibetan. ${ }^{5}$ There are very close parallels between the production of these Tibetan materials and equivalents in Kashgar, presumably because of guidelines handed down to local offices by the central office of the Chinese People's Political Consultative Conference which sponsored the entire project.

\section{Cultural and Historical Materials on Kashgar City}

The initial stimulus for the book, and the nucleus of the Chinese sources on which it has been based, is the Kashi shi wenshi ziliao 喀什市文史资料 (Cultural and Historical Materials on Kashgar City) in twelve concise volumes that are not clearly dated but

\footnotetext{
4 British India was partitioned into India and Pakistan when the colonial government withdrew in 1947. Xinjiang today has borders with Pakistan and the contested territory of Kashmir. The district of Aksai Chin, over which China and India fought in 1962, is now administered by Khotan County.

5 Melvyn C. Goldstein A History of Modern Tibet, 1913-1951: the Demise of the Lamaist State Berkeley University of California Press, 1989, pp. xiii-xiv and A History of Modern Tibet Volume Two: The Calm Before the Storm 1951-1955, Berkeley University of California Press, 1989, pp. xiv-xv.
} 
were published between 1982 and 1997. In addition, four volumes of selections from local collections of wenshi ziliao that were originally published in various parts of Xinjiang and collected together as Xinjiang wenshi ziliao jingxuan (Selections from the Xinjiang Cultural and Historical Materials) have also been consulted - although they contain little additional information on the situation in Kashgar - as have other Chinese sources including the official Xinjiang jianshi (Brief History of Xinjiang) and Western accounts of Kashgar and other parts of Xinjiang before 1949. The wenshi ziliao publications relating to Xinjiang include volumes on Aksu city, the Bayingolin Mongol Autonomous Prefecture, Beiting, Bortala, Buerjin County (in Kazakh), Changji, Hami, Yining, Shihezi, Urumqi among other towns and counties and significantly since this was the organisation behind the project - reports on the work of the Chinese People's Political Consultative Conference in Xinjiang.

The extensive and rather curious wenshi ziliao (Cultural and historical materials) project was intended to cover the whole of China and the Kashgar volumes are merely a small part of the publishing enterprise of that project. The series of, what were for the most part, slim volumes was published during the 1980s and 1990s under the auspices of the Chinese People's Political Consultative Conference (СРPCC). The CPPCC is the united front body that was created in 1949 to provide a forum for ethnic, religious and political minorities to voice their opinions. It was also part of an attempt to create a degree of legitimacy for the newly established People's Republic of China beyond the membership of the CCP and provided a framework for incorporating non-communists and their views into the political structures of the new state. It still plays an important role in the political life of the PRC, especially in ethnic minority areas. It operates alongside central and local organisations of the CCP and the National People's Congress, but it no longer has the credibility as a broadly based united front organisation that it enjoyed briefly in the early 1950s.

The astonishing range of articles published in the wenshi riliao collections includes accounts of the contemporary history of China at both national and local level, narratives that were written by participants in, and witnesses of, that history or written narratives that were constructed on the basis of their oral testimonies. Many of the writers were not members or supporters of the Chinese Communist Party although, not surprisingly, there is no place for articles directly opposed to or criticising the CCP in these collections. These accounts cannot be considered by any stretch of the imagination to be impartial or objective historical documents, but they do permit the modern and contemporary history of China to be viewed from alternative perspectives and not solely as it appears when has been passed through the filter of the CCP's propaganda agencies. For these reasons these publications were originally classified as neibu, 'internal' which were originally produced solely for circulation within Communist Party and government bodies. They were not 'secret' or 'classified' in the western sense but were not intended for wider distribution. Publication abroad was strictly forbidden and neibu documents should not in theory have been acquired by foreigners. As China became more open less 
attention was paid to these classifications and volumes of the wenshi ziliao series could be found in provincial bookshops. ${ }^{6}$

The quality of the material in the Kashi shi wenshi ziliao volumes is uneven. Many of the historical narratives are anecdotal and personal; they include reminiscences of military and political heroes of the CCP's occupation of Kashgar who were known to the authors. Some accounts are hagiographical, vainglorious or selfserving; others have clearly been motivated by a desire to set the record straight and to allow the authors to have the last word in political quarrels that have been festering for decades. This biographical material, which is often the most informative in the collection, includes accounts of the work done by members of a group of CCP activists in Xinjiang in the 1930s and 1940s; these accounts are reminiscent of Victorian lives of the saints or tales of missionary endeavour. The heroes and heroines are worthy, energetic, enthusiastic and full of confidence; they may well have been irritating and insensitive individuals, but it is difficult not to be impressed by their dedication to their cause and their self-sacrifice in challenging circumstances. These accounts are invaluable as they contain unusually detailed information about events and attitudes that is difficult to uncover elsewhere. Whatever their shortcomings it is important that the Kashi shi wenshi ziliao materials and others like them should be more widely known.

It is the earlier volumes that contain the most useful and detailed information on Kashgar and its political history. Although some of the later volumes also have relevant articles, these are diluted by more propagandist pieces on 'nationalities unity' [minzu tuanjie] and some less controversial material about Kashgar, including the style and decoration of buildings, construction of sewerage system and the provision of running water supplies - admittedly important. Other articles cover topics such as the return of Hong Kong to China that seem out of place in what started out as a publication devoted to local history and related issues and it is probable that a decision was taken not to continue with publishing articles as revealing as some of those in the first few volumes.

There are no wholly reliable Chinese-language histories of Kashgar, or even of Xinjiang as a whole although the three-volume official Xinjiang jianshi (Brief History of Xinjiang), produced under the auspices of the local branch of the Chinese Academy of Social Sciences, is a useful reference tool for the history of the whole of the region if used critically. ${ }^{7}$ The level of detail that is provided by the Kashi shi wenshi ziliao documents, henceforth referred to as Kashi, justifies a degree of confidence in the picture that is painted in them, although they must of course also be read critically and with caution. There is sufficient internal consistency between the different accounts to indicate that the recollections are based on real experiences, but there are also interesting discrepancies which suggest that, even though the

${ }^{6}$ For example the present writer was able to acquire five volumes of the Linxia wenshi ziliao xuanji 临 夏文史资料选辑 (Selections from the Linxia Cultural and Historical Materials) in Linxia (formerly Hezhou)

7 Xinjiang Academy of Social Sciences, Historical Research Insitute (ed.) Xinjiang jianshi (Brief History of Xinjiang), 3 volumes. Urumqi: Xinjiang People's Press, 1980. 
editorial processes may have removed sensitive material, the censors have not been so severe or efficient that they have sanitised the accounts completely or reduced their value. The account of the history of the Kashgar region that is presented in Xinjiang and the Expansion of Chinese Communist Power: Kashgar in the early twentieth century is based on a close and critical reading of key articles in the Kashi collection, articles that have not been referred to in previous studies and have certainly never been used in detail in existing Western histories of the region. As the stories are told and retold by, and about, different individuals, a composite picture of the complexity of the society and culture of Kashgar and its southern Xinjiang hinterland begins to emerge, albeit a picture of the region primarily from the point of view of the Chinese officials sent to work there.

The provenance of many of the individual articles in Kashi is far from clear although the general principle behind the collection is set out below. How the authors were selected, under what circumstances the documents were transcribed, and to what extent and by whom they were edited, is not explained. There has been a long-standing suspicion that some accounts, although not necessarily those in the Kashgar collection, emerged from written testimonies that the authors were obliged to prepare during campaigns of political struggle. A number of important articles are based on the reminiscences of individual members of the CCP who operated, either openly or clandestinely, in Kashgar and its region in the 1930s and 1940s. Some of these reminiscences were written accounts by the participants themselves; others were oral testimonies that were then used as the basis for articles written specially for this collection. Documents in the Kashgar District Archives are also referred to, although without precise citation, and these archives, which are not currently open to Western scholars, are likely to contain other autobiographical material that is not cited in the Kashi series.

\section{The creation of the Kashi series}

An official account of the genesis of the Kashi series appears in a postscript to Volume 1.

Volume 1 of Kashi shi wenshi ziliao was compiled under the guidance and supervision of the Kashgar Municipal Committee of the Chinese Communist Party and the Chinese People's Political Consultative Conference. In the process of editing, we were enthusiastically assisted by old comrades and others of the older generation, especially the contributors to this volume. The Kashgar Municipal Library and Regional Archives and the Kashgar College of Education were also very helpful.

A similar editorial afterword to Vol 2 adds a little more information.

${ }^{8}$ Kashi shi wenshi ziliao (1:97. 
The publication of Volume 2 benefited from the support of many of the older generation from various work units. Members of the Culture and History Research Committee [Wenshi yanjiu weiyuanhui], Wang Yinglin, Memet, Usman and other old comrades put forward valuable suggestions. In the editing process, great support was received from leaders and comrades in the regional archives, the post and telecommunications office, Kashgar Daily and other work units, especially the deputy editor of Kashgar Daily, Comrade Dai Depei, who was of great assistance and to whom we are extremely grateful. Twelve articles have been collected here [in Volume 2] of which three have been translated [from Uyghur]. Most of the writers have based [their texts] on documents, recollections and oral accounts that were written down and edited. Time has passed so there will inevitably be discrepancies between the recollections and the reality. There are limitations because of time and space as the different people involved could not be everywhere on every occasion and much more material is needed to fill in the gaps and reflect the historical reality. ${ }^{9}$

The editors clearly wished to make the point that Uyghur colleagues played a part in the project and that Uyghur language materials were used, if only in translation. The reference to both 'old comrades' and 'others of the older generation' indicates that the compilers deliberately included the recollections of non-party members. The reference to limitations may have been a form of words designed to protect the editors against criticism for not adhering to a clear political position on the complex and contentious history of Kashghar.

In spite of the caveats that have been mentioned, the Kashi series is extraordinarily valuable. Unlike other materials which deal with Xinjiang as a whole, it focuses specifically on Kashgar and other towns and rural areas of southern Xinjiang rather than treating the province or region as a whole and it contains accounts of historical episodes from different points of view. Many of these narratives reveal a level of detail that is missing from the more widely available histories of the same period. Kashi also permits the reader to get inside the minds of CCP members who operated in Xinjiang before 1949, to see the society and political structure of Xinjiang as they saw it, and to comprehend the events of those years through the eyes of some of the participants. It reveals Chinese, and to some extent Uyghur, perspectives on Xinjiang in the 1930s and 1940s and makes it possible to understand their motivation for the work that they undertook in trying to modernise the region in the way that they thought best.

\section{Cadres and colonialism}

What can be learnt from the activities of these pioneering CCP cadres about the attitude of the Chinese Communist Party to Xinjiang both before and after 1949? The cadres were committed and driven by ideological and patriotic impulses to

\footnotetext{
${ }^{9}$ Kashi 2:109.
} 
ensure that Xinjiang remained part of the 'motherland'. They were in no doubt that it had always been part of China and that it should always be so. In this they were the inheritors of a tradition that can be traced back to those members of the Qing Dynasty government who decided in 1884 that the region should not be lost to China and should become a full province. From the accounts of the work and attitudes of the cadres in Kashgar and its region that are presented in the Kashi series, it is clear that they became aware - some more than others - that in Kashgar, Tashkurgan and Khotan they were operating in a society that was vastly different from anything that they had previously experienced, whatever part of China they came from or had worked in. If they had not become aware of this, they could not have managed offices, schools or military units at all. Whether they fully appreciated quite how different the region was, it is impossible to say. Without the language skills necessary to talk to Uyghurs and other Muslims in southern Xinjiang who could not speak Chinese well - the vast majority - they were not able to acquire a profound appreciation of how local society operated and especially how issues that were particularly important to the CCP, such as education and the status of women, were affected by time-honoured customs and practices sanctified by Islamic religious authority. Conversely, because they were not constrained by local ethnic loyalties and either respect for, or fear of, the combined religious and secular authority that the bays, begs and the imams exercised over the remainder of the population, they were able to see more clearly than some Uyghurs the inequities, and indeed the iniquities, of an economic structure that exploited and marginalised the poorest Uyghur farmers. Does this mean that the administration eventually established by the CCP in Kashgar and the rest of Xinjiang, and that was based to some extent on the experiences of these cadres in the 1930s and 1940s, was a colonial regime or, as has been suggested, a form of 'internal colonialism'? Barry Sautman has argued that, although scholars and journalists have frequently used the phrase 'internal colonialism' to describe the relationship between the central government of the People's Republic of China in Beijing and the Xinjiang Uyghur Autonomous Region that was created on 1 October 1955, 'none of the elements of the internal colonialist concept are sufficiently present to warrant characterising Xinjiang as an internal colony of China', taking into account the political economy of the region and in particular the interaction between the Han and the minority, that is the Uyghurs. This is debatable in view of the acknowledged existence of ethnic conflict in the region, the fact that before 1949 the Uyghurs were the majority rather than the minority. Subsequently, a low degree of autonomy and the unevenness of development in Xinjiang, especially southern Xinjiang, have left Uyghur farming communities impoverished and marginalised. Indeed even the 'internal' element of 'internal colonialism' has to be questioned as it assumes that Xinjiang was always 'internal' to China, which it clearly was not. ${ }^{10}$

${ }^{10}$ Sautman, Barry, 'Is Xinjiang an internal colony?’, Inner Asia, Vol. 2, No. 2, 2000, pp. 239-71. 


\section{The Kashi narratives}

The regime that controlled Kashgar and the rest of Xinjiang before 1949 was not the same as the one established by the PRC, although there are interesting continuities which may be accounted for partly by the experience of the CCP cadres working in the region during the governorship of Sheng Shicai from 1933 to 1944. What cannot be in any doubt, on the basis of the accounts given in the Kashi documents, is that the attitudes of the predominantly Han officials who ran Kashgar and southern Xinjiang in the 1930s and 1940s, including those seconded by the CCP leadership in Yan'an, were typical of the colonial district officer, a wellintentioned and reform-minded district officer perhaps, but a colonial officer at heart. Although many had some knowledge of, or at least respect for, the language and culture of the Uyghurs on one level, where this culture clashed with their beliefs and principles of equality and fairness, they rejected the practices of that culture completely. Although some Uyghurs were willing and able to support the CCP cadres in this, others were constrained by ethnic and religious loyalties and the Communist officials were not able to carry these Muslims with them on their path towards reform. To some extent the difference depended on the social background of the Uyghurs, but some CCP cadres assumed that they would have the support of all poor Uyghurs, whether pious or not, and this was not the case. It is difficult to read the narratives in the Kashi series without coming to the conclusion that, whether or not they intended to, the narrators have provided copious evidence to support the argument that what was being developed in Xinjiang between the 1920s and the 1940s by both Nationalist and Communist officials was a colonial administration. The level of detail provided in the Kashi series unwittingly, but comprehensively, undermines the contention that Chinese officials in Xinjiang were, and indeed still are, ruling over a region that was simply another part of China and was essentially no different from provinces like, for example, Henan or Jiangxi.

Many of the articles in the collection cite historical evidence selectively to support Beijing's official stance that Xinjiang has always been part of China and always will be. Even when that is not argued directly, it is the underlying assumption behind most of the articles. The official position of the People's Republic of China is that the area now known as the Xinjiang Uyghur Autonomous Region (XUAR) is an integral part of China and always has been, since at least the Han dynasty (206 BC-AD 221), notwithstanding the great changes that the geography and polity of China have undergone over the centuries. The writers of the articles in Kashi and most of those whose story is told there appear to have accepted this without question, particularly those who were sent to work in Xinjiang on the instructions of the Chinese Communist Party in the turbulent years of the 1930s and 1940s. However, it is important to note that this belief was also shared by their counterparts in the Nationalist Guomindang and its military units and previously by some members, although not all, of the ruling elite of the Manchu Qing dynasty, the final 
ruling house of the Chinese Empire which created the province of Xinjiang in 1884. The conviction that Xinjiang is an inalienable part of China is not based on any Marxist or Leninist analysis, although Stalin's unsophisticated views on the national question - the role assigned to ethnic minorities in the Soviet Union have been used to justify it. It is essentially a nationalist or patriotic conviction, a conviction not shared by most of the non-Han population of the region. The depth of this conviction, above all among those Han officials who had served in the region and formed an attachment to it, is part of the explanation for, but not a justification of, the refusal of policy makers in China even to consider the possibility that, at some point in the future, an independent or at least a genuinely autonomous regime might be established in Xinjiang. In fact there is every reason, on ethical, political and practical grounds, for arguing that policy makers in China should be looking for alternative models of government to solve the problems of Xinjiang - and also Tibet and Inner Mongolia - before further conflicts make these even more difficult to resolve. Whether such alternatives might involve full independence or genuine practical autonomy within the existing autonomous regions, at the time of writing there is no reason to be optimistic that any progress is being made towards this goal, or even towards the possibility of debating these issues rationally in China.

\section{$7 \quad$ Uyghur voices}

Although there are some Uyghur voices in the collection of texts from Kashi on which this account is primarily based, they are far fewer than those of their Han colleagues and even those few Uyghur narratives have been mediated, in ways that are sometimes transparent and sometimes not, through a Han Chinese political and editorial process. None of them represent the common view of Uyghurs in Xinjiang, that the land belongs to the Uyghurs and that they should be responsible for governing themselves in a Muslim society. Even among the Uyghurs there have been, and still are, many and varied notions of the form of self-government appropriate to Xinjiang; the type of society that it should be; and particularly the precise role that Islam should play in that society. The question of what relationship an independent Xinjiang might have to China is rarely discussed by Uyghurs. The origins of many of these notions, and their implications for the future of Xinjiang, can be found in the history of the attempts to establish an independent Muslim Uyghur regime in Kashgar during the 1930s, the failure of that attempt and the experiences of members of the Chinese Communist Party in the region after that failure.

Although the research for Xinjiang and the Expansion of Chinese Communist Power: Kashgar in the Twentieth Century relied heavily on the Kashi source material and other primary sources in Chinese, it has been supplemented by consulting British diplomatic papers on Xinjiang that are lodged in the National Archives (the former 
Public Record Office) and the British Library in London. The documents available in the British diplomatic archives include letters, reports and diaries produced by the British Consulate-General in Kashgar during the 1930s and 1940s as the Consul and his staff attempted to comprehend the political unrest in the region, the complex triangular relationship between Xinjiang, China and the Soviet Union, and above all the implications of events in Xinjiang for British India, which was their highest political priority in Asia. Many of the documents produced by the Consulate-General were compiled for the information of the British Embassy in Beijing and the government of what was then British India. These important and revealing documents provide corroboration of, and contrast to, the narrative found in the Kashi series.

\section{On the ground in Kashgar}

The book benefited greatly from travels throughout most of the region of Xinjiang from the early 1990s and in particular from visits to the city of Kashgar in 2001 and 2010. Although the face of Kashgar has altered dramatically since the 1930s, the layout of the old city remained essentially the same until recently and it is still possible to imagine without much difficulty the environment in which the dramatic events of the 1930s and 1940s described in the Kashi series took place.

The Chinibagh Hotel in Kashgar was the site of the British Consulate-General until 1947: unfortunately only a part of the original building remains and there is no trace of the celebrated garden, but it is still possible to take meals every day within yards of the office in which the Consul and his staff composed their reports. Reading copies of these reports in a room close to where they had been written made possible a clear view from Chinibagh of the history of Kashgar. This site of the former British Consulate is only fifteen minutes away on foot from its Russian and Soviet counterpart in what is now the Seman Hotel, a short distance over which to play the Great Game of Asian diplomacy.

Sadly the destruction of the old city and the traditional Uyghur neighbourhoods that began in about 2006 is all too apparent As far as possible this demolition and the impact of the devastation on the local people were documented with a camera and this material will appear in a subsequent book Xinjiang in the Twentyfirst Century which will also bring the story of Kashgar up to date.

\section{Conclusion}

In spite of its limitations, the Kashi series of reminiscences provides an unparalleled if not unique window into kashgar in the 1930s and 1940s and the lives and opinions of Chinese Communist Party members working in the region. Using them in parallel with Western diplomatic documents, other Chinese sources and fieldwork in Kashgar has demonstrated that they are of considerable value if read critically 
and that their narratives are reliable in comparison with other sources from the same period.

\section{Bibliography}

Kashi shi wenshi ziliao 喀什市文史资料[Cultural and Historical Materials on Kashgar City], Kashgar, no publisher, 1982-97 (12 volumes)

Yu Junsheng (ed.) Xinjiang wenshi ziliao jingxuan 新疆文史资料精选 [Selections from Xinjiang Cultural and Historical Materials], Urumqi: Xinjiang People's Press, 1998 (4 volumes)

Xinjiang Academy of Social Sciences, Historical Research Insitute (ed.) Xinjiang jianshi 新疆简史 (Brief History of Xinjiang), 3 volumes. Urumqi: Xinjiang People's Press, 1980. 


\title{
Oirat Texts written in the Clear Script (todo üsüg) preserved at the Ili River in Xinjiang ${ }^{1}$
}

\author{
Erdemtu Minggad (Minzu University of China, Beijing)
}

The Ili River originates from the northern slope of the peak Khan Tngri, 6995 meters high above the sea level, the second highest peak of the range of the Tngri Mountains (Tian Shan) which play an important role in Central Asia. The river flows down like a proud dragon jumping from the sky, with the same majesty. Further on, as it flows from the west to the east from Kazakhstan it reaches China after originating with its main water from the glacier of the Tngri Mountains. In the upper part the river has three tributaries: the Künggüs (in Chinese and other languages also Kunges/Kunes), the Tekes and the Qasi (Kax/Kash), and together they are like wrathful lions, galloping and snarling. When the Künggüs River going to the north joins the Qasi River it becomes the Ili. The Ili River when going to the west joins with the Khorgus (Horgos) River and enters Kazakhstan again. In its lower part the river passes 3000 miles including such ancient cities as Alimatu (Almaty) and goes on into the Balkhash Lake where it finally rests.

In the upper stream region of the Ili River live Mongols who are mainly Ölets of the Four Oirats (known as "a piece of marbled meat, a part of the Golden Law"'). They concentrate in the Uyghur Autonomous Region in Xinjiang, in the Kazakh Autonomous Prefecture, in the following counties (xian in Chinese): Mongolküre (Zhaosu), Tekes, Čabčiyal or Qapqal Xibe Autonomous County, Nilka, Tokkuztara, Yining, Korgas and Yining city (Kulja). There are two reasons for

\footnotetext{
1 Translated by Agata Bareja-Starzyńska

2 Alay miqan-u tasurqai . altan yosun-u kelterkei.
} 
their presence in this place. With regard to the Mongolküre majority of Ölets, they are the remnants from the great massacre of Jungars who were destroyed by the Manchu Qing dynasty in 1755-1758. Those who live in other regions are Torguts who escaped the same fate in 1771 from Jungaria and Jungars themselves who survived purges and united with them. ${ }^{3}$

Ölets who live in six districts of Mongolküre, in ten districts of Nilka and šabi nar and in four districts of Tekes and Tokkuztara are Mongols of the upper stream Ili River.

For ten years between 2000 and 2011, I worked there on the basis of the doctoral degree grant of the State Foundation of Social Sciences, a special grant of the State Foundation of Social Sciences, the grant of the Association to Develop Japanese Research (grant for co-operation of scholars from Mongolia, Japan and China), the grant for teachers of the Minzu University in Beijing, as well as state and university grants for co-operation with foreign scholars.

I examined state, province and city registers, archives, museums, libraries and cultural centers and particularly private collections of many regions, including Urumqi, Khobogsair (Hoboksar), Altay, Bayingolin, Bortala and Ili of Xinjiang; Hailar, Ningcheng, Huhhot and Alasha of Inner Mongolia; three provinces of Northeastern China: Harbin, Mukden (Shenyang) and Changchun; Chengde of Hebei province; and in Mongolia: Ulaanbaatar, Uvs and Khovd.

As the most fortunate I regard my discovery that there was a very strong cultural influence to preserve Mongolian books in the regions as far as from the western border of Ili to the region of Kharchin Tümed, and I found work on this subject the most meaningful in my life. Deeper understanding of Mongolian intellectual tradition and Mongolian culture became possible owing to this.

It is not only an important proof that Mongolian nomads preserved books with love and care, treating them as precious, like gold and gems. They also impressed the world by creating a culture of numerous substantial books.

During my research fieldwork the most astonishing were the collections of mainly early books written in the Clear Script (todo üsüg), kept by the Ölets living in the upper stream Ili River. Important places for preservation of books by the Ölets are: Mongolküre of Mongolküre district, Qaraganatu (Čerig-un Agta-yin Talabai [i. e. military horse pedigree breeding]), sumun Urtubulag, Tugulčin Bulag, sumun Čagan Usun, sumun Šatu Kirgis, sumun Qosumtu Qara Usun, Saiqan Toqoi, Egülder Morin-u Talabai (i. e. pedigree horse breeding) of Ili, 74, 76-dugar Tuvan (i. e. military regiment), Egülder Qonin-u Talabai (i. e. pedigree sheep breeding), Tekes district and Gova city, sumun Qujirtu, sumun Ničügün (second sumun), Čabčiyal

\footnotetext{
3 The Oirat or Jungar are Western Mongols. A part of them moved west to the River Volga after 1600 and is known as Kalmyk. One tribe of the Kalmyk, the Torghut, moved back to Xinjiang around 1771. In 1757 the Chinese-Manchu Qing-Empire destroyed the Jungar Empire. Most Jungar in Xinjiang did not survive the following purges of 1757/58. In 1771 the returning Torghut were resettled in the upper Ili valley. The name Jungar was banned in China after 1758. Instead the name Ölet was used. The Oirat consist of four main groups: Jungar, Dörbet, Khoshut, Torghut. The name Oirat or Jungar is often used as a name for all four groups. (J. Reckel ed.)
} 
Ügerči (eighth liyan [i. e. company]), Sön Talabai (i. e. dairy farm), sumun Üliyesütei of Nilka, sumun Kökeqotugur, Köke Tal-a of Tokkuztara and Yui Shu of Yining County.

Some people keep two hundred books, some keep over a hundred. The collections of those who have only a few dozens of them are not regarded as impressive. Here, Mongolian texts written in the Clear Script constitute a collection of over several thousand books and it is without any exaggeration a collection which is several times bigger than any of the official collections in China. ${ }^{4}$

Among these texts there is Altan Gerel (Sutra of the Golden Beam) printed in Kalmykia at the beginning of the $18^{\text {th }}$ century, which is the earliest blockprint of this text. There are also many other very rare and important texts, including the xylographic version of the Naiman minggatu, which is the Mongolian version of the Sanskrit Aștasähasrikā-Prajñääramitä-Sütra. It was printed in 1742, at the time of Galdan-Tsering Khan and it is the earliest blockprint in the Clear Script kept in China. Until now, as far as we know, the Ölets living in the upper stream Ili River, are those meritorious ones, who keep the biggest number of books written in the Clear Script in the whole world.

Upon the request of two rulers of the Jungars: the eldest son of Bayibagas Khan, Vchirtu Tayiji (or Vchirtu Sechen Khan or Sechen Khan) and his younger brother, Ablai Tayiji (or Ablai Bagatur), in 1648 Rabjamba Zay-a Bandida Namkhaijamso (Tib. Nam mkha'i rgya mtsho) of the Shangkhas, belonging to the Gürööchi clan of the Khoshuds, who earlier had become a monk in place of Bayibagas Khan's son and went to learn Dharma in Tibet, upon his return, in the valley of the Chu River, invented todorqai is ïg, i. e. the Clear Script, later called in short todo üsüg, which was a new Mongolian script.

The Clear Script was used not only by the Four Oirats, but it also became an important tool in foreign relations in Central Asia. This fact was commented upon by many scholars so there is no need to dwell on it here again. However, it can be mentioned that the Clear Script was used mainly by the Jungars and Torguts, and not so much by the Khoshut, who mainly settled in Tibet and the Kukunor area.

The Clear Script, having been used for over three hundred years, in the $20^{\text {th }}$ century had to face changes. In the 1920s the Russian Kalmyks and in the 1940s the Oirats in western parts of Mongolia stopped using the Clear Script and started writing with the Cyrillic alphabet. At the end of the 1970s the Oirats of Xinjiang in China were encouraged to use the Uyghur-Mongolian script and in the 1990s the Clear Script which used to be taught at schools suddenly ceased to be the subject learnt by the children.

Nevertheless in Xinjiang there are still occasionally books, journals and newspapers printed in the Clear Script, but the Clear Script suddenly may become the

\footnotetext{
4 See Inoüye Osamü, Minģad Erdemtü, Amur gengei, Sayinbayar gengei, Dusan, Tötübatu nar

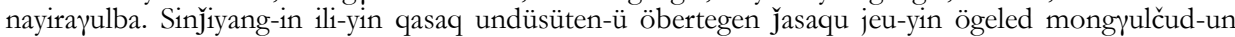

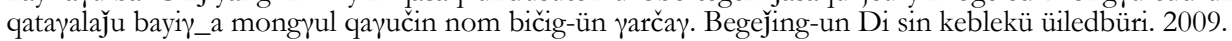


most recently abandoned among the writing systems used by the Mongols in the past.

Why did the Oirats of Jungaria invent the Clear Script? What was the reason they eventually abandoned it? Mongolian politics, religion and other connected factors may answer these questions.

Moreover, to truly learn and understand the layers covering secrets of this mysterious nomadic culture is not a simple task. The Mongols are not that simple. Mongolian nomads who achieved high living standard did not only continuously improve their script but they continue to do so today. And moreover, there are signs that they will do it in the future.

The script is said to be the most important agent of culture. Script besides its outer shape and the fact that it is a tool to maintain relations of one society with others, by producing each sound animates the entire ethnic culture, gives life to its skeleton, blood and flesh by becoming its soul and even more. Which script among those which were used and which are being used by the Mongols has truly been approved by the Mongols themselves as scientific?

Nowadays scholars defend their own locality, each one their own, or say things from the position of their personal interest. It is regrettable that there are a very few who look on the problem from the higher position of the culture of Mongolian nomads.

Mongolian scholars should draw conclusions concerning the problem introduced here: change of the script, especially its good sides. They ought to examine this from many perspectives, such as history, culture, state and religion, society, language, science etc. in the period of several hundred years that have passed. But because this sort of work is very decisive, it has not been done properly, which is regrettable.

Wasn't it a cultural loss that the Mongols have abandoned one script and accepted another? And if it was a loss, was it significant or not? Is it not one of the important tasks of our times to do research and review critically this unexpected deed of the Mongols who kept changing their own script!

When examining from the distance only within the last one hundred years or so the shift from the Clear Script to the Uyghur-Mongolian Script and from the Clear Script to the Cyrillic, and then from the Uyghur-Mongolian Script to the Cyrillic - how is it possible not to learn from historical experiences and not to draw conclusions and learn your lesson?

The Clear Script was not invented very early (1648), however, among the scripts which have been used by the Mongols it comes just after the UyghurMongolian Script. Documents written in the Clear Script have been preserved carefully in China, Mongolia and Russia. The number of preserved documents is second only to those in the Uyghur-Mongolian Script.

The Clear Script belonged not only to the Four Oirats living on the borders of the Mongolian world and thus should not be neglected. It should rather be seen as 
an important agent of the Mongolian culture. Monuments in the Clear Script are a significant part of the composition of the culture of Mongolian nomads.

The first scholars who did research on documents in the Clear Script were the $19^{\text {th }}$ century Russian scholars. Yu. S. Lytkin, A. Popov, A. Bobrovnikov and K.B. Golstunski did a lot of work on the documents in the Clear Script.

Later, from the 1950s onwards also scholars of Mongolia did quite a substantial work. Academicians B. Rinchen, Tsendiin Damdinsüren and V. Tsoloo in the period of the 1950s-1960s were the outstanding leaders in this field. In the 1970s Kh. Luvsanbaldan continued the work they had begun. Work of Kh. Luvsanbaldan, collecting and preserving monuments in the Clear Script together with his research on the Clear Script and its writings, conducted on a considerable scale, became a very significant achievement. In China, from the 1980s, Qu. Batai, Erdeni, Altanorgil and Si. Norbu directed scholarly work on the Clear Script.

It is very regrettable that due to different reasons in the 1990s studies on the monuments in the Clear Script were discontinued in many countries. However, at the beginning of the $21^{\text {st }}$ century they began to reappear. One of the proofs is the series Oyirad sudululiyin nomiyin sang (Biblioteca Oiratica) which is published in Ulanbator in Mongolia by the Center of Clear Script Studies.

Studies on the Clear Script do not concentrate solely on the research which was done earlier and could be predicted. The reason for that is the fact that along the western borders of China, in western provinces of Mongolia and among the Kalmyks living in Russia, there is a considerable amount of books kept by common people. They have not been included into scholarly research until now, there has not been a catalogue of these works and we may say that the work on them is starting only now. This is not to say that the study which has been done so far should be discarded. Furthermore, it should be emphasized that in the future research on these materials should definitely be taken into consideration.

Now I would like to introduce some of the findings of my fieldwork done on the Clear Script sources preserved in the upper stream Ili River. After that I will describe subjects found in the contents of the texts written in the Clear Script. In the end I will outline plans for further research.

\section{Survey of the fieldwork on the documents in the Clear Script done in the upper stream Ili River}

It is astonishing how Oirats of the upper stream Ili River, one of the veins of Central Asia, preserved in their memory hidden truths of their history and culture: wise elders told me endless stories similar to fairy tales and legends. The upper stream Ili River used to attract scholarly attention like a magnet. However, fieldwork research on the Clear Script documents undertaken there since 1949 till today can be divided into three phases. 


\subsection{Research on the documents in the Clear Script in the 1950s}

In the 1950s, when new China was established, scholars who went to Xinjiang to collect written materials were Mergenbagatur from the Inner Mongolian Institute of History, Language and Literature (nowadays Inner Mongolian Institute of Social Sciences) and Coyijungjab from the University of Inner Mongolia. The Chinese Inner Mongolian Institute of Social Sciences holds the biggest collection of early Mongolian texts with considerable number of important and rare works.

It is a direct result of persistent and enduring work of Jürungga, Dorongg-a, Erdenitogtaqu, Mergenbagatur, Coyigungjab and others from the older generation of scholars. They traveled all over the country and collected Mongolian texts. Mergenbagatur, who traveled to Xinjiang, is one of those scholars. His visit to the upper stream Ili River and search for books is still remembered by people living there. Nowadays those Oirat works which are kept in the Library of the Inner Mongolian Institute of Social Sciences are mainly texts collected by him.

Collections built by Mergenbagatur and others at that time were successful due to the fact that the local governments and people were not only directly involved in the work, but they showed their genuine support towards the project. Later, when the "cultural revolution" was on, these texts, and there were many, were kept secretly safe from destruction and in this way it was beneficial for the collection.

Collector Mergenbagatur, with his profound knowledge, knew well the value of the cultural heritage that he had amassed. He stored all of the collected items in the library. During the most difficult period those who had built the collection stored it in the library making it common property. It was an act of courage, responsibility and confidence which should be learnt from them. It is regrettable that during ten years of disorder of the "cultural revolution" (1966-1976) some of the texts vanished from the library collection.

\subsection{Search for sources in the Clear Script from the 1970s till the 1990s.}

After the "cultural revolution" (1966-1976) the work of collecting sources in the Clear Script started again. On the 15th of June 1982 the Institute of Ethnicities of the Chinese Institute of Social Sciences and the Institutes of Ethnicities, Religion and Economy of the Institute of Social Sciences of the Xinjiang Uyghur Autonomous Region as well as the Department of History of the Xinjiang University established together a "Research Group on History and Society of the Mongolian Ethnicity in Xinjiang." Within 54 days this group did field research on the lands inhabited by Mongols in Xinjiang. They had as their main objective creating a "collection of historical and religious sources and material objects of the Mongols in Xinjiang." This scholarly investigation initiated assembling sources in the Clear Script following the "cultural revolution."

On the 17th of July of 1984 the State Ethnic Affairs Commission established all over the country groups in order to lead the process of editing and publishing early 
texts of ethnic minorities with small number of members. Also local Ethnic Affairs Commissions, prior to that or later, each established an office. In this way offices set up by the state contributed to the work of collecting and preserving texts of ethnic minorities.

After establishing the office for editing and publishing texts of ethnic minorities in the Xinjiang Uyghur Autonomous Region, Batu and Galdan and other officers went across Xinjiang and collected several hundreds of texts in the Clear Script. Among them were many texts found amongst the Ölets inhabiting the upper stream Ili River region.

Qu. Badai, vice-head of the Government of Xinjiang Uyghur Autonomous Region, Head of the Country Political Council, Altanorgil from the Pedagogical University, Erdeni S. Norbu, ex vice-head of Xinjiang University, To. Badm-a. Tö. Jamsu from the People Printing House of Xinjiang, Buyangsig from Inner Mongolia University, Batu and Galdan of the Office of Editing and Publishing Texts of ethnic minorities in the Xinjiang Uyghur Autonomous Region are the main representatives of this period. At the time of those studies research was conducted mainly under official leadership, however, also quite significant work was undertaken by individual people.

Part of the material collected during this phase was placed in the collection in a proper way. However, it cannot be forgotten that also quite a significant number of rare and important materials was taken away and became private property of individuals, officials or leaders. These documents have not been publicized, unfortunately. Only some documents while being taken away were copied and copies were given to the locals. Some of the people who took the books died. Now there is no way to learn which texts have been taken away. It has to be stressed that as a result of this behavior, owners of the books which were taken from them, not only lost their confidence in scholars, but were later causing problems to the researchers. For example, in the 1950s Mergenbagatur conducted his collecting work out of love and responsibility for his culture. However, some people say: "Mergenbagatur arrived, cheated us, took our books away and left." This became a common phrase which united people. Quite often I myself also heard such sayings and explained that Mergenbagatur placed the books in the library, and only a small number of them disappeared during the "cultural revolution," while all the others remained in the library. While doing work for the culture one has to face people of all sorts of characters, egoistic or rude. One not only has to study one's culture, but it is also a duty of man of writing to preserve and protect culture. But oppressing, hiding and making a private property is not useful to scholarly work. And in the study of ethnic culture it is forbidden. 


\subsection{Studies of the Clear Script documents at the beginning of the $21^{\text {st }}$ century}

As it has been mentioned above, my fieldwork was done in the upper stream Ili River in 2000-2011. During these ten years my main work was to catalogue source materials preserved among the Oirats in Xinjiang. I used to take pictures of every page, especially when staying at the foot of the Tngri Mountain, where I established my center of the four districts at the upper stream Ili River: Mongolküre, Tekes, Nilka and Qapqal, and every year for a few months I did my fieldwork there.

Every time I discussed with the owner of the text if he agreed that I take pictures of every page with a digital camera. If a person did not agree, I took notes about the biography of the owner, wrote down the text title and measurements of the book. My work focused on getting the approval of the text's owner. Even when I was offered to take the text with me, I did not do it as I decided to stick to strict rules. During the first two times there was a clear technical difference since in order to take photographs I used modern techniques of that time, namely camera and films and in this way the texts have been preserved till now.

\section{Monuments in the Clear Script kept at the upper stream Ili River with regard to their contents}

The basis for my fieldwork were written monuments preserved at the upper stream Ili River. In terms of contents, these texts can be divided into several subjects, listed below.

\subsection{Correspondence and legal documents}

Correspondence and legal documents which are known to us till today present the largest number among documents kept in China and Russia. Those kept in the Russian archives have been quite well studied or used for research. In the Historical Archive No 1 in China and Archive (Dangsa ebkemel-ün gajar) of the Xinjiang Uyghur Autonomous Region as well as in several local libraries and archives there is still correspondence awaiting researchers to study it.

In the Historical Archive No 1 in China there are preserved important letters from the end of the $17^{\text {th }}$ century and from the $18^{\text {th }}$ century. In the Archive of the Xinjiang Uyghur Autonomous Region there are three important documents connected with the $18^{\text {th }}$ century history as well as plethora of correspondence dealing with the history of Oirats.

These documents have not been carefully studied so far by anyone and have not been used in scholarly works as source materials. In comparison with Russia and Mongolia there exist less historical documents written in the Clear Script pre- 
served in China. Nevertheless, in China materials in archives and registers, which are connected with Oirat history and culture are not small in number and there can be found important documents among them.

There are not many letters among the documents in the Clear Script kept at the upper stream Ili River. What has been preserved is mainly correspondence circulating between monasteries and temples during the time of the Republic of China kept by individuals.

Collecting official documents and studying them have been rather thoroughly conducted by Java-yin Dusan from the Pedagogical Center of Tekes district in the Kazakh Autonomous Province. He was able to ascertain that these documents had been preserved by Qogayin Genjab (b. 1949-), a retired physician from the Qujirt Mongolian sumun of Tekes district.

These are the documents which were circulating between the monastery of Tekes Qutugtu (Teges-ün qutugtu-yin küriy-e) and the monastery of Ili (Ili-yin süm-e keyid). Ayildar, Genjab's uncle, was in the past a monk in the monastery of Teges Qutugtu and after his death the documents were passed to Genjab.

Moreover, in the private possession of Java-yin Dusan there are objects connected with Oirat history, namely two edicts (yasiq, Tib. bka' shog) presented by the Fifth Dalai Lama to the Oirat temple. Also in the hands of Eligen-ü Osor from Sagaralqan of Qaltagan sumun of Egülder Morin-u Talabai of the Nilka district there is one private letter written in the Manchu language.

\subsection{Historical texts}

There exist a considerable number of historical texts written in the Clear Script, preserved in Russia and Mongolia. In China there is a very small number of such historical works assembled in official collections. However, in the upper stream Ili River it was possible to discover several historical texts. Among these writings there is a famous text written in the 1690s called Saran-u gerel, or "Light of the Moon, the Story of Rabjamba Zaya Pandita" by Ratnabhadra (in short "Light of the Moon").

It covers the life story of Zaya Pandita from his birth in 1599 till his death in 1662 and some events which happened in the period between 1662 and 1691 in connection with the incarnation of Zaya Pandita, when he was a child. It is a rare and important historical text which accurately describes religion, politics, economy and army of the $17^{\text {th }}$ century. Several manuscripts of this text have also been found in Russia and Mongolia. So far we know that in China there is one manuscript of "Light of the Moon" kept by Kadar Narmai-yin Badm-a, who is a pensioner from the Kazakh Autonomous Province at the Ili River.

According to Java-yin Dusan this manuscript of "Light of the Moon" was kept in the monastery of Tekes Qutugtu. At the beginning of the "cultural revolution" Lama Ayildar hid it with somebody he trusted in the Cagan Qad-a in Qulusutai and eventually it was recovered. In the 1970s Narmai-yin Badm-a went to the monas- 
tery of Tekes Qutugtu, borrowed the "Light of the Moon" manuscript and has been keeping it till this day.

The monastery of Tekes Qutugtu at the time of destruction in 1676 by Vchirtu Tayiji and Galdan Bushugtu was moved to the Volga region (Ijil jai). Furthermore a part of shabi nar (i. e. subjects) of Zaya Pandita are the people who established it in the Volga region. In 1755 they came from the Volga region to Tekes and settled down there. Manuscripts written in the Clear Script which were kept by shabi nar of Zaya Pandita are very important, and one of them is "Light of the Moon." But the fact that this valuable manuscript has been kept in private hands for over thirty years is very regrettable. It remains unavailable for scholarly work and for publishing.

The original place of an anonymous work Jegünyar-un tuyuji eng uridu aysan uridu qoyar orosibai which is now becoming known to us and which is an important text on Oirat religion and history, remains unknown. During my fieldwork in 2002 2004 I heard about four copies of this text. One was kept by Bayangsig, a teacher in the secondary school in the Mongolküre district (he died suddenly). Two copies were kept by Qotalategüs Ligsid of Egülder Morin-u Talabai of Ili. One was kept at the collection of physician Cagan-u Möngkebatu of Urtubulag sumun of the Mongolküre district. Historical sources in the Clear Script which pertain to Oirat religion and history are very small in number. The text mentioned here, a very important source, was unknown until 1990.

In the collection of Qotalategüs Ligsid besides the text described above, there is also a historical work entitled in Oirat Mongyoliyin uq eikin touji (Class. Mong. Mongyol-un ur eki-yin tuyuji). In the past this text was not studied and has not been published in the form of facsimile. This rare and important text was known only from one note-book, but last year we found its original copy.

\subsection{Sources on language and literature}

There are not many sources on language at the upper stream Ili River. The existing ones are mainly handbooks of alphabet of the Clear Script, its transcription as well as explanations and translations. Regarding literature, there exist more texts than on the language. Two main representatives are great anthologies of Jangyar and Geser.

Jangyar belongs not only to Mongolian folklore, this composition is also considered an apex of poetry. There used to exist numerous manuscripts of Jangyar, but now those transmitted in a traditional way are small in number. Manuscripts of Jangyar are valuable monuments of Mongolian literature. In the past manuscripts of Jangyar used to be found at the upper stream Ili River. Nowadays some people still preserve them with due care.

Besides Jangyar in 2004 during our research in the Mongolküre district we also took pictures of the Geser anthology entitled in Oirat Arban jügiyin ejen Geser xān angdulman xāni doroyidulaqsan bölög orošiboi (Class. Mong. Arban jüg-ün ejen geser qayan 
andulaman qayan mangyus -i doroyiduyuliysan ...) and in Oirat Arban jügiyin ejen Geser xāni touji orošiboi (Class. Mong. Arban jüg-yin ejen geser qayan-u turuji orosibai) and now we are preparing them for publication.

Furthermore, there are rare and valuable compositions which should be included in the history of Mongolian literature, such as in Oirat Galdan xäni onol namancilaqsan (Class. Mong. Galdan Bošoytu qayan-u unal namančilal [Confession of Galdan Bushugtu]), which is similar to the lament of Togon Temür when he lost his city Daidu, ran away and recited the confession of his sins. There are also other texts which have never been studied.

\subsection{Sources on religion}

Regarding the texts in this group, they are mainly translations from Tibetan. These are texts on Buddhism. At the upper stream Ili River we can find only Buddhist texts. No texts on any other religion have been found. At the beginning of the $17^{\text {th }}$ century, under the leadership of the nobleman Bayibagas all Four Oirats accepted Buddhism. As it was mentioned before, in 1648 Zaya Pandita, at the request of two sons of Bayibagas, Vchirtu Tayiji and Ablai Bagatur, invented the Clear Script. The majority of texts which were traditionally transmitted are translations from the time of Zaya Pandita.

At the upper stream Ili River there can be found many books written in the Clear Script. Not only are they not placed in official collections, but there also exist numerous authentically rare texts, such as Altan Gerel, printed in the $18^{\text {th }}$ century by the Kalmyks from the Volga region. Other examples which should be mentioned here are the "Prajnyaparamita in 8000 Verses" (or in Sanskrit AstasäbasrikāPrajnäpäramitäin), called in Oirat Nayiman mingyan-tu orošiboi (Class. Mong. Nayiman mingya-tu orosibar), printed in 1742 or the text of the Buddhist sutra carved in a rock in Cagan Qada (White Rock) in Nilka.

\subsection{Other sources}

Besides the four main topics of sources discussed above there are also sources connected with religious practices and rock inscriptions. When Ölets propitiate obo, i. e. sacrificial cairns, they prostrate and call it tnger-e mörgökë (to propitiate gods). During the propitiation of gods they produce čuculi-yin bičig (document of cučuli) and thus protective deities and local deities of land and water are not only entrusted but also many important mountains and rivers as well as land names are mentioned in the document almost without omission.

When relations are being established between parents of a new couple, there is a custom called josu talbiqu yosu (custom to set money). In this custom words are very meaningful. There exists a text called yosu-yin üge orosibai (words of the custom). Moreover, we can also find texts connected with such practices as copying and recitation of a religious text, and others. 
On the slope of the Tngri Mountain (Tian Shan) there is a cave in a place called Qonggorbulag. In front of the cave there is a painting on a rock and an inscription in the Clear Script. There is also Otači (or Medicine Buddha) painted there and animals such as a dog, a deer, a turtle and others. The inscription is both in the Clear Script and in Tibetan, it says "Otači" in the Clear Script and the mantra is presented in Tibetan. So far it seems to be the only known rock inscription in the Clear Script. We received reports about other examples of the Clear Script rock inscriptions in the upper stream Ili River, however, we did not have time so far to examine them and we plan to do it in future.

Summing up, it can be concluded that according to my estimation the upper stream Ili River is the region in which the worldwide largest collection of texts written in the Clear Script (todo üsüg) is kept in the hands of a small number of individuals, while the whole area deserves attention of scholars on Mongolian history and culture.

\section{Illustrations}

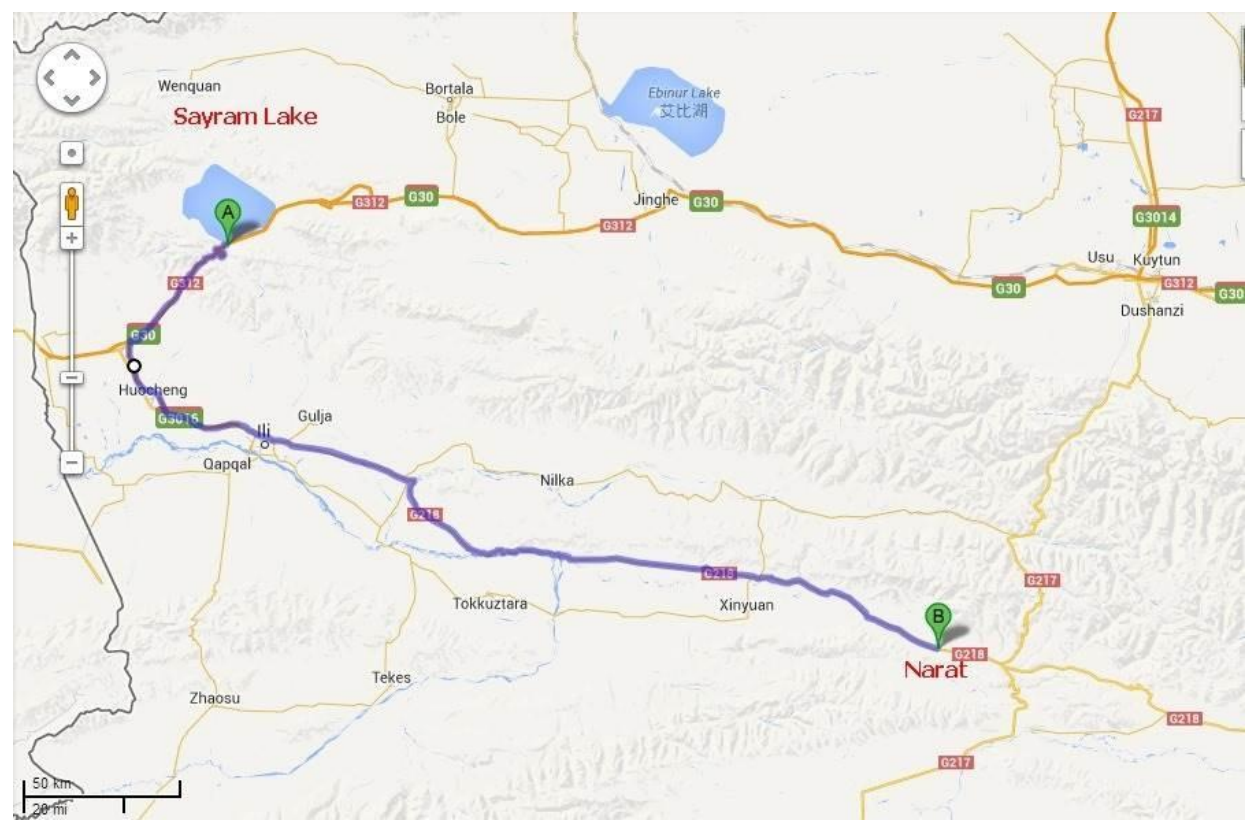

Figure 1: Map of the upper stream Ili River 


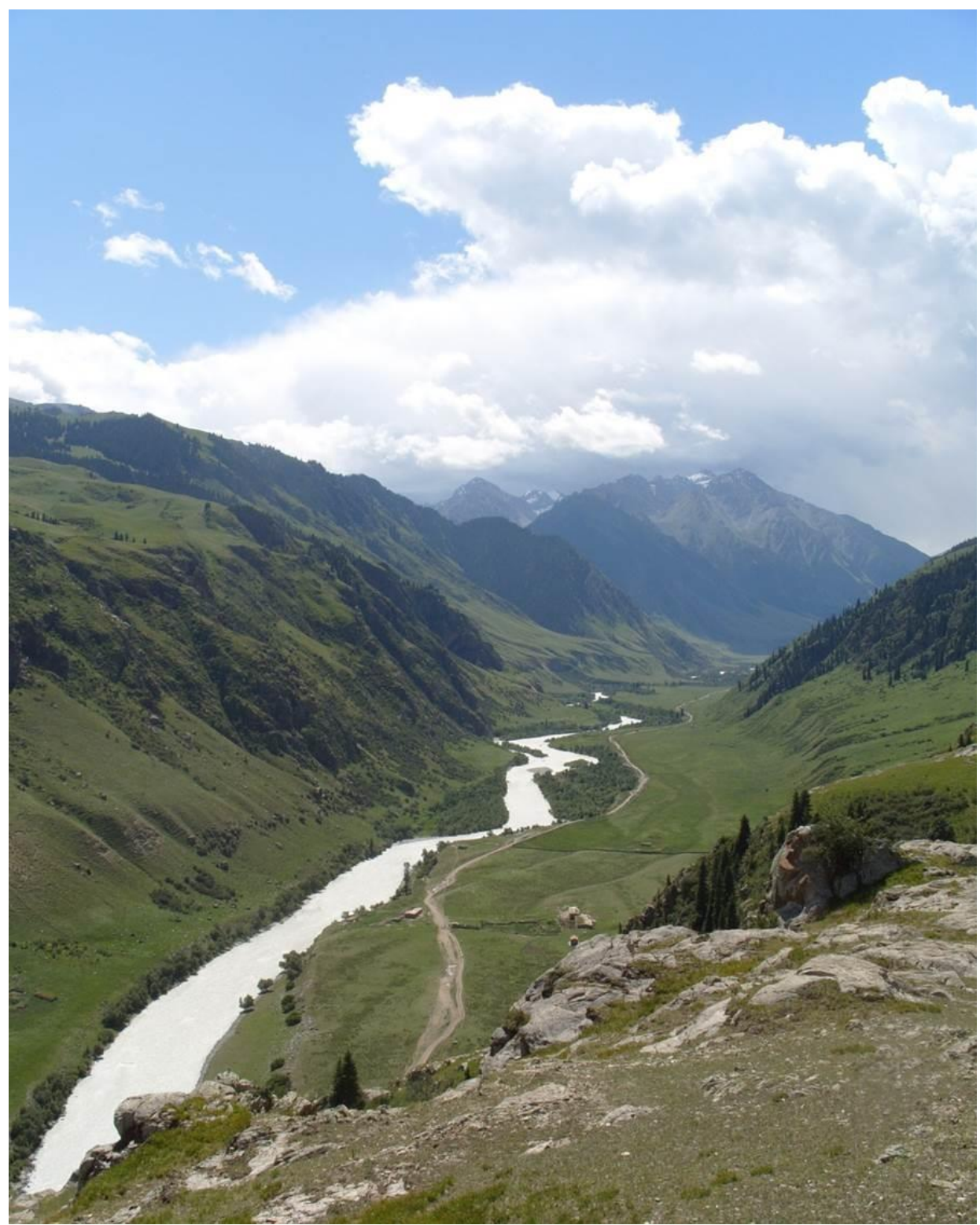

Figure 2: Upper stream Ili River (photo by the author) 


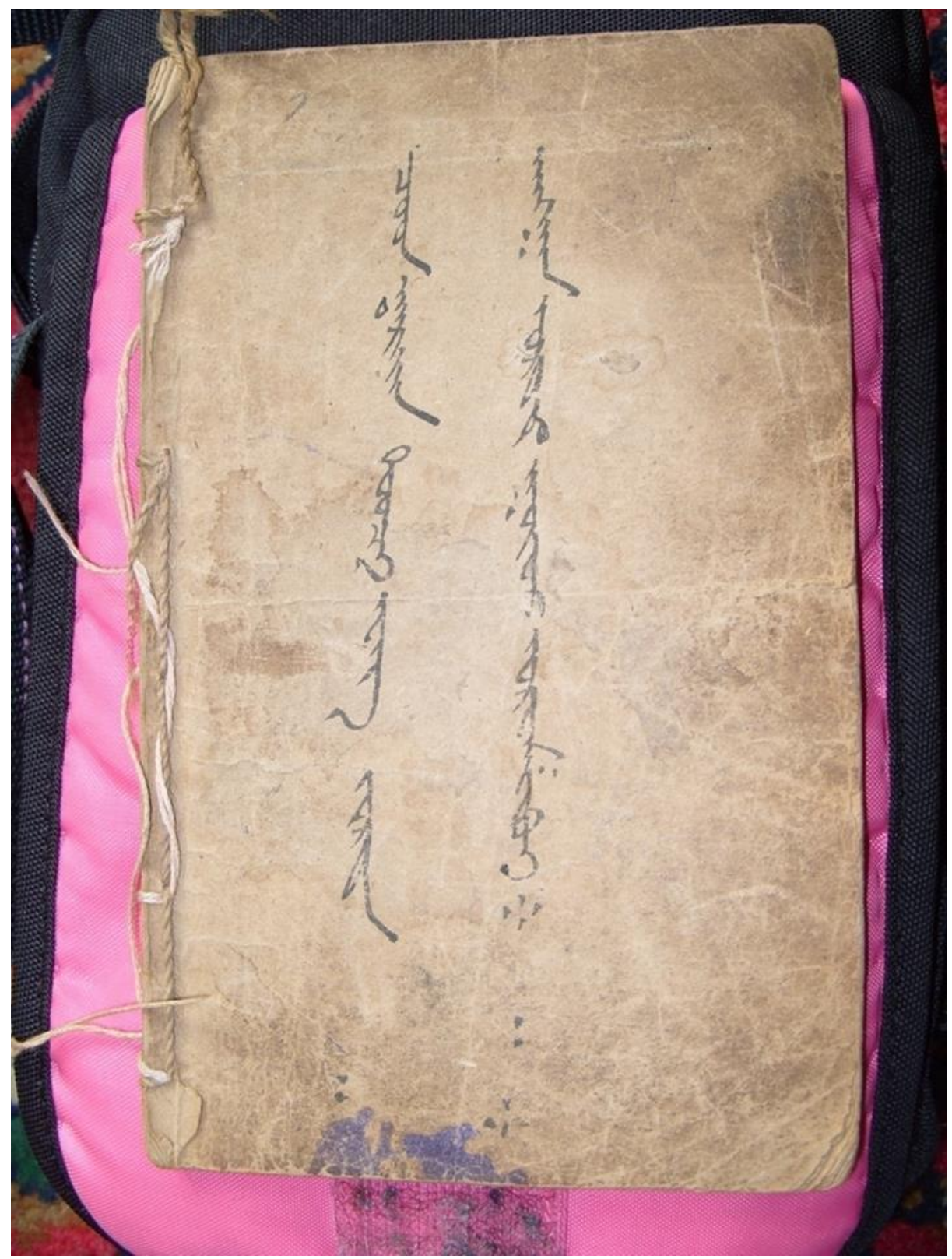

Figure 3: Jüün yariyin touji eng urda angxan urdu qoyor orošiboi 


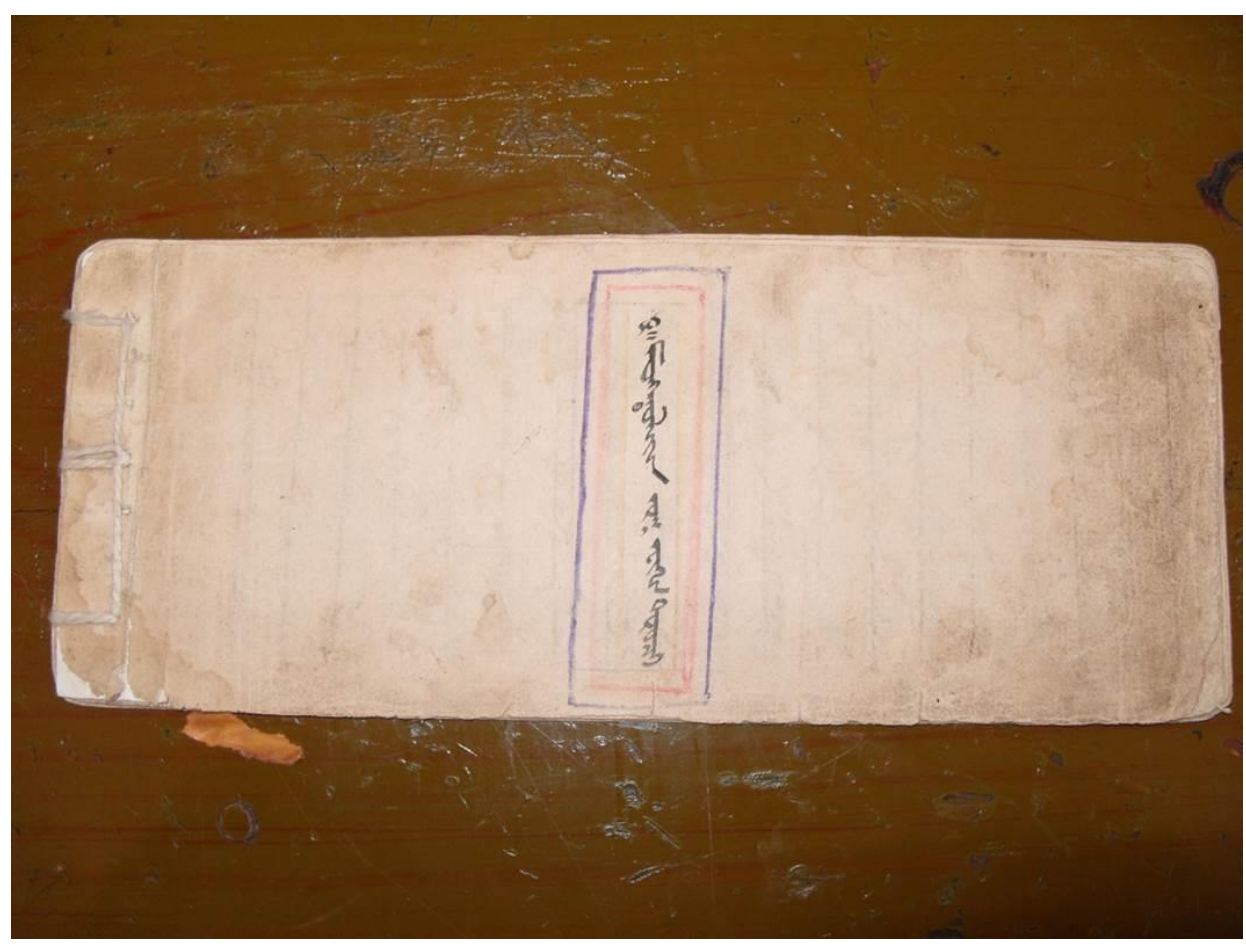

Figure 4: Mongyoliyin uq eikin touji

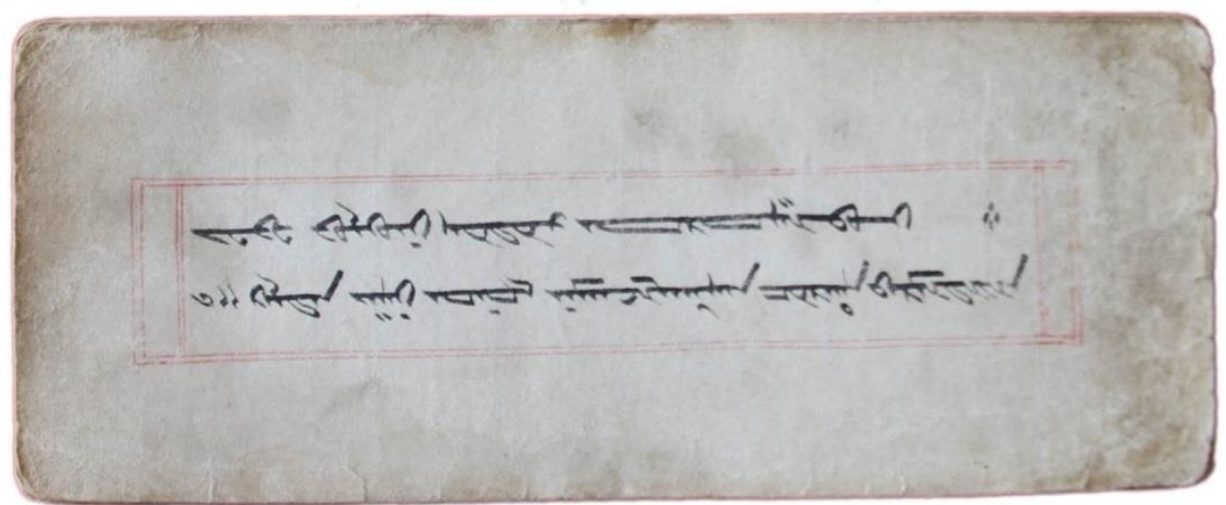

Figure 5: Galdan xāni onol namancilaqsan 


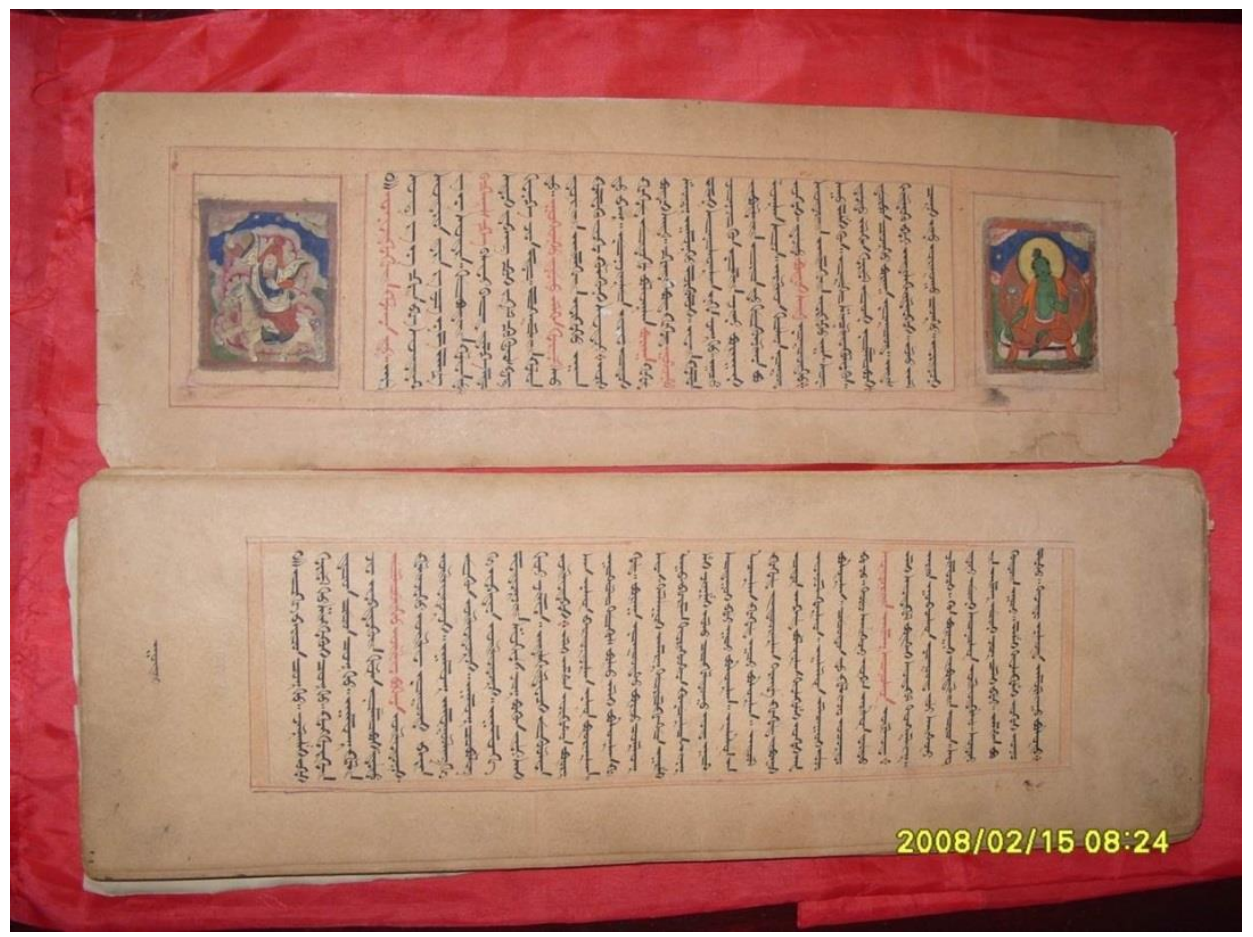

Figure 6: Altan Gerel 


\title{
Mongolian Voices of Discontent in Lifanyuan Records of the early Qing-period
}

\author{
Dorothea Heuschert-Laage (Universität Bern)
}

\section{Introduction}

Over the recent decades, an enormous amount of Manchu and Mongolian language archival material from the Qing period (1636-1911) has been published in China and in Mongolia. This ushered in a new era of research on the so-called outer regions of the Qing Empire. However, as other archival collections in the world, Qing archives can only preserve fragments and the historian will find that some voices have been silenced. ${ }^{1}$ According to Beatrice Bartlett, the Manchu court used archives as an instrument of its power. In order to portray the government as all-powerful and effective, anything which did not fit in with this picture was omitted and, "for the Qing archivists, protecting the imperial face was the all-important goal"2 In order to ensure that nothing damaging would be on file in the archives, documents were not only destroyed, but sometimes files were classified in the wrong order and events retold in a different context. ${ }^{3}$ For this reason, evidence of disrespect for imperial authority or expression of local autonomy was - in most cases - eclipsed.

When archival material was later used for the compilation of official court histories, it was again subjected to a process of selection and adjustment. All infor-

\footnotetext{
${ }^{1}$ Ladwig, Roque, Tappe, Kohl, Bastos, "Fieldwork between Folders”, pp. 20/21.

2 Bartlett, "Qing Statesmen, Archivists, and Historians and the Question of Memory", p. 423.

3 Weiers, "Die Historische Dimension des Jade-Siegels", pp. 121-124 and p. 135.
} 
mation which was not particularly flattering for the court was filtered out. Accordingly, the Huang Qing Kaiguo Fanglüe, a compilation commissioned in 1786 to glorify the history of the Manchu royal house before 1644, leaves no doubt that by the mid-seventeenth century the Mongols living south of the Gobi were firmly integrated into the Qing Empire. We are informed that in May 1636 forty-nine representatives of sixteen Mongolian polities urged the Manchu ruler to adopt an honorary title and on the occasion of the proclamation of the Qing dynasty vowed allegiance to the emperor. ${ }^{4}$ The court's authorized tale of Mongol authorities joyfully accepting Qing overlordship was circulated most freely, and still has an impact on our understanding of the momentous decision of the Mongolian nobility to accommodate with Qing rule. For this reason, it is interesting to occasionally find archival evidence that Mongolian authorities at the time were not as submissive to imperial rule as official history tries to make us believe.

\section{Codes of Conduct and Non-violent Protest}

In 1659, a memorial was made by the Lifanyuan informing the emperor that two prominent rulers of the Qorčin Mongols had bluntly rejected the imperial invitation to come to the capital. The Qorčin leaders did not even attempt to make their declining answers sound submissive. Lifanyuan officials were deeply concerned by what they considered as disrespectfulness and summarized the provocative remarks of the Qorčin leaders with these words: ${ }^{5}$

"When you, the emperor, said 'I want to get along well with you like a close relative, come!' the Joriktu Cin Wang ${ }^{6}$ and the Darhan Baturu Giyūn Wang ${ }^{7}$ of the Qorčin did not happily come. Instead, the Joriktu Cin Wang did not ask for an imperial order, but, on his initiative, said 'Because of the illness of the imperial princess I will postpone my arrival.' The Darhan Baturu Giyūn Wang brought forward all sorts of things like 'I caught a cold' and 'Moreover, my wife has a

\footnotetext{
${ }^{4}$ Hauer, Huang-Ts'ing K’ai-kuo Fang-lüeh. Die Gründung des Mandschurischen Kaiserreiches, pp. $395 / 396$.

${ }^{5}$ Manchu language memorial preserved in the Collection of Manchu-Mongolian routine memorials from the Lifanyuan, dated Shunzhi 16/intercalary3/24 (May 14th, 1659). in Qing chao qianqi Lifanyuan (2010: vol. 1, 217): (top 8) horcin i joriktu cin wang . (9) darhan baturu giyün wang . (10) ++ dergici cohome niyamarame acaki jio sehede . uthai urgunjehei jiderakū (11) elemangga joriktu cin wang oci . (12) ++ hese be bairakū . ini cisui gungju nimere be dahame jidere be tookaha (bottom 1) sehebi : darhan baturu giyūn wang geli beye edun dekdehebi : gege geli (2) hefeli aššahabi : juwe omolo akū oho seme hacilame baita (3) tucibume. (4) ++ hese be jurceme wesimbuhengge ambula giyan de acahakūbi : This passage is also discussed in my paper "From Personal Network to Institution Building".

${ }^{6}$ Died in 1666 and was succeeded by his younger brother Biltagar (Qing chao qianqi Lifanyuan 2010: vol. 1, p. 401/402).

7 Title of Manjusiri (died 1665), who ruled the middle banner of the Qorčin of the left wing. For this

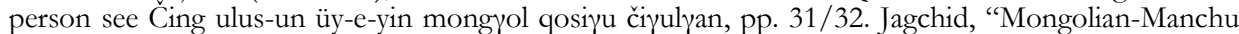
Intermarriage in the Ch'ing Period", p. 77 relates that in 1628 Manjusiri had married a daughter of Yoto (died 1638), who was a grandson of Nurhaci. The girl was later adopted by the emperor as his daughter.
} 
stomach upset. ${ }^{8}$ Two [of your] grandchildren ${ }^{9}$ have [already] died.' and acted contrary to the imperial order and what he handed in as a memorial was greatly disrespectful."

The Qorčin refusal is not immediately understandable. In 1659, it was more than thirty years ago that representatives of this polity had allied with the ancestors of the Qing imperial house..$^{10}$ Moreover, Qorčin Mongols were among the Mongolian noblemen, who in 1636 formally acknowledged Hong Taiji (reigned 16271643) as the first emperor of the Qing dynasty. Lifanyuan officials were outraged by the way how the Qorčin princes answered to the imperial correspondence. In the case of the Joriktu Cin Wang, they found fault with the fact that he had not asked for imperial permission to postpone his visit, but had simply declined the invitation. The Darhan Baturu Giyūn Wang was accused of evasiveness, because he had offered a variety of different excuses. Moreover, even though the emperor had stressed their close family relations, the Darhan Baturu Giyūn Wang may have been too explicit about his and his wife's health condition.

When looking for traces of Mongol opposition to Manchu rule what naturally comes to mind are instances of armed resistance. For the seventeenth century, the Čaqar may be the most prominent example of Mongols, who renounced their bond with the imperial house and in 1675 launched an attack on Mukden. ${ }^{11}$ Moreover, the Sönid Mongols under their leader Tenggis may be seen as another example of Mongolian opposition. Tenggis had shown respect to the emperor in 1637 and in 1641 had been granted the title of a Jun Wang. However, in 1646 he renounced his loyalty to the emperor, openly rebelled against the dynasty and joined the Sečen Qan of the Qalqa. ${ }^{22}$ As in the case of the Čaqar, his maneuvering was answered by a military campaign.

The passage under discussion can be understood as an expression of non-violent resistance against Manchu rule. As the example of the two Qorčin princes relates, members of the Mongol nobility also expressed their discontent by rejecting patronizing attitudes of the court and not complying with rules of behaviour. In retrospect, there can be no doubt that the secure status of the Mongolian nobility under Qing rule went hand in hand with a loss of political autonomy. ${ }^{13}$ The influence of Mongols and Mongolian matters at the court dwindled and, likewise, the competences of Mongolian regents and their sphere of responsibility within their own polity was more and more curtailed. Some members of the Southern Mongolian nobility were aware of their growing marginalization and did not hesitate to express their unease. Even more than two decades after their formal integration into

\footnotetext{
8 The expression hefeli aššambi is documented in Xin Manhan da cidian, p. 395.

${ }^{9}$ For the omission of the plural suffix (Doerfer, Der Numerus im Mandschu, pp. 38-41).

10 Weiers, "Der Mandschu-Khortsin Bund von 1626", p. 415.

${ }^{11}$ Fang, "Hsiao-tuan Wen Huang-hou", pp. 304-305.

12 Kennedy, "Minggadari”, p. 576.

${ }^{13}$ For the changing status of the Southern Mongolian nobility: Di Cosmo, "A Historical Analysis of Manchu-Mongol Relations”, p. 181.
} 
the Qing Empire, they found room to maneuver and used the diplomatic arena in order to assert their own political position.

The two Qorčin noblemen had been close confidants of the father of the Shunzhi emperor (1644-1661) and are mentioned in the Huang Qing Kaiguo fanglüe among the Mongolian noblemen, who feasted with Hong Taiji shortly before his death in September 1643 after a victory over Ming China. ${ }^{14}$ Both Qorčin leaders were married to imperial princesses. ${ }^{15}$ Together with their wives they had been guests at the court in August 1654 and had attended an imperial banquet. ${ }^{16}$ There can be no doubt that the two princes did not just want to postpone their visit at the court, but were taking a political stance by declining the imperial invitation in a rather provocative manner. The impression that the Qorčin princes did not want to alienate the court but adopted this policy in order to negotiate for more privileges cannot be totally dismissed. Affronting the emperor by disrespectful behaviour may have been a strategy pursued to gain more recognition and imperial attention. In retrospect, this seems to be convincing in the case of the Darhan Baturu Giyūn Wang who in July 1659 was elevated from Giyūn Wang (prince of the second degree) to Cin Wang (prince of the first degree). ${ }^{17}$ However, when looking at the immediate response of the Lifanyuan officials, the Qorčin princes' letters seem to have caused adverse reactions. When drafting a proposal for the emperor of how to deal with the two noblemen, the Lifanyuan insisted that the two princes should be punished for their disrespectfulness and should be brought to the capital and blamed there. The emperor rejected this proposal and ordered the Lifanyuan to discuss the matter again. The imperial answer to the memorial of the Lifanyuan goes as follows: ${ }^{18}$

"When I said 'come' and 'let us reconcile with the Joriktu Wang and the Baturu Wang like close relatives' they didn't listen to my order and did not come. Obviously, this comes up to a breaking of law and their prevaricating and excuses were greatly disrespectful. Your ministry should get together with the officials of the three banners, ${ }^{19}$ discuss the matter and make a memorial! Drop [the idea] of bringing the princes here!"

\footnotetext{
${ }_{14}$ Hauer, Huang-Ts’ing K’ai-kuo Fang-lüeh. Die Gründung des Mandschurischen Kaiserreiches, p. 573.

15 This follows from the plural gungiu se used earlier in the document.

${ }^{16}$ Qing chao qianqi Lifanyuan 2010, vol. 1, 71/72.

${ }_{17}$ Qing chao qianqi Lifanyuan 2010: vol. 1, no. 137, 222/223.

${ }^{18}$ Imperial rescript in Manchu language to the memorial of the Lifanyuan of Shunzhi 16/intercalary3/24 (May 14th, 1659) in Qing chao qianqi Lifanyuan (2010: vol. 1, 217): (1) joriktu wang baturu wang be niyamarame acaki (2) seme jio seci hese be donjihai uthai jiderakū (3) yasa de fafun akū adali bulcame siltahangge (4) ambula giyan de acahakūbi : suweni jurgan . ilan (5) gūsai hebei ambasai emgi acafi gisurefi wesimbu : (6) wang sa be ubade gajira be naka : The rescript is also discussed in Heuschert-Laage, "From Personal Network to Institution Building".

19 Plain Yellow, Bordered Yellow and Plain White banner. Elliott, The Manchu Way. The Eight Banners and Ethnic Identity in Late Imperial China, p. 404n147.
} 
In his invitation, the emperor alluded to the family ties between the imperial house and the Qorčin nobility and used a terminology which emphasized affection and closeness. In the rescript, however, when addressing the Lifanyuan, he makes clear, that his invitation was an order (in Manchu: hese) and not to appear was against the law (in Manchu: fafun aku). It seems that for all parties concerned, the warm invitation to a family reunion could not conceal the obligatory character of his letter. This is an important point, because it is characteristic of the nature of the relationship, which was characterized by a parallel use of a vocabulary of affection and the emphasis on family ties and at the same time outright political pressure. The two Qorčin princes took up the familiar character of the invitation, but they not only refused to accept it, but also failed to answer the letters of the emperor with adequate courtesy and affection. This was a clear breach of the principles relevant in a patronage relationship which was both personal and political. According to the rules of patronage, verbal formula emphasizing mutual affection, gratitude and respect were essential for maintaining the bond between the two sides. ${ }^{20}$ The absence of this vocabulary indicated discontent. It was a clear signal and, accordingly, at the court it was interpreted as hostile behaviour.

In the context of European medieval history, Gerd Althoff stressed that acts of government were performed in public in order to make visible the ruler's claim to authority and influence. ${ }^{21}$ By taking part in ceremonies at court, participants showed their willingness to accept the sovereign's superiority. It was a symbolic act of commitment aimed at uniting the group into a whole and defining the status of individuals in relation to others. The special importance the first Qing emperor in his communication with the Mongolian nobility placed on formal expressions of respect and a correct terminology suggests that in the early Qing period symbols, signs and rituals were not only means to demonstrate differences in status, but had constitutive functions and were a way to establish hierarchies. Defining codes of behaviour was a way of creating and maintaining social and political relations and, by the details of ceremony, every participant was granted a certain position within the structures of the polity. ${ }^{22}$ As Barbara Stollberg-Rilinger has shown, symbolic communication was especially meaningful when state structures were weak with only limited potential to enforce decisions and a strong orientation to reach consensus among political actors. ${ }^{23}$ In this context, the imperial rescript, according to which the Shunzhi emperor rejected the proposal of the Lifanyuan to bring the princes to Beijing by force, is significant. As the case of the renegade leader Tenggis shows, use of force was an option, but for the Qing it was not the only possible way of disciplining unruly behaviour on part of the Mongolian nobility. For the two Qorčin princes, to be removed to Beijing against their will would have

\footnotetext{
${ }^{20}$ Emich, Reinhardt, von Thiessen, Wieland, "Stand und Perspektiven der Patronageforschung".

21 Althoff, Die Macht der Rituale.

22 Heuschert-Laage, "Defining a Hierarchy: Formal Requirements for Manchu-Mongolian Correspondence Issued in 1636".

${ }^{23}$ Stollberg-Rilinger, "Symbolische Kommunikation in der Vormoderne”, pp. 517/518.
} 
been an outright humiliation. Such a step would inevitably lead to a change in the nature of the Manchu-Mongolian relationship, which so far maintained the appearance of a voluntary agreement. Injuring the dignity of leading members of the Mongolian nobility who had been on close terms with the Qing ruling house since decades would also have been a signal to other Mongolian leaders.

Among the Mongol confederations, which had joined the Manchu project by 1659, the Qorčin can be said to have been the most influential one. Qorčin Mongols were particularly well represented in Manchu-Mongolian intermarriages. ${ }^{24}$ In the legal field, a number of regulations drafted for the Mongolian nobility in the seventeenth century include exemption clauses for members of Qorčin nobility. For example, the Mongolian Code drafted in the Kangxi period stipulates that the Tüsiyetü Cin Vang and the Joriytu Čin Vang of the Qorčin were the only Mongolian authorities who were allowed to retain part of the fine they had imposed on nobles under their command. (The remaining part of the payment had to be shared among the noblemen of their jurisdiction). In the case of all other Mongolian banner rulers, who had imposed fines on noblemen under their command, the part of the fine "due to the government" (jasay-tur) was collected by the central government. 25

However, the number of rules including special allowances for the Qorčin nobility is small compared to the amount of rules, which more or less equally pertained to all Mongolian noble houses regardless of their standing prior to their affiliation with the Qing. For this reason, I believe, even though we do not know the concrete reason for the Qorčin rejection of the imperial invitation, it very likely was a reaction to attempts of the court to establish a standardized procedure for the Mongolian elite who had accepted Qing overlordship - a group which as such had not existed until recently. For the Qorčin nobility, to come the court not only redefined their position vis-à-vis the emperor, but also placed them on a par with other members of the Mongolian nobility, who likewise were granted imperial audiences on a regular basis. Qorčin princes as the most influential among the Qing Mongol nobility may have thought it beneath their dignity to be summoned to Beijing and to be treated according to a system of rules, which was more or less equally applied to all members of the Mongolian nobility. The personal character of the invitation and the fact that it apparently was brought forward incidentally, could not obscure the fact that in Manchu Mongolian relations there had been a trend towards formalization and standardization. ${ }^{26}$

\footnotetext{
${ }^{24}$ Jagchid, "Mongolian-Manchu Intermarriage in the Ch'ing Period", pp. 85-87.

25 Regulation dates from the second half of the 1670s. Heuschert, Die Gesetzgebung, pp. 151/152.

${ }^{26}$ Heuschert-Laage, "From Personal Network to Institution Building".
} 


\section{Archival Material as a Counterbalance to Court Publications}

As a conclusion, I will raise some questions on the potential value of archival material vis-à-vis narratives and administrative codes which - in lack of other information - are often referred to as sources to reconstruct Mongolian history during the Qing period. The tendentiousness of military histories, which were compiled and circulated in order to celebrate the glorious victories of the dynasty, has been emphasized on various sides. ${ }^{27}$ According to B. Oyunbilig and Michael Weiers, in eighteenth century historical narratives, events of the seventeenth century were frequently embedded in the political framework of the eighteenth century. ${ }^{28} \mathrm{Narra}-$ tives of Mongolian noblemen's visits to the court in the early seventeenth century present a similar picture: According to the Huang Qing Kaiguo Fanglüe (1786), as early as August 1643, the court had specified fines to be paid by members of the nobility who did not appear at a court meeting. This regulation explicitly did not refer to meetings in the context of military campaigns, but to regular meetings in the capital or meetings convened by the emperor. ${ }^{29}$ As discussed above, however, in the case of the Qorčin, the emperor rather tried to avoid the impression that Mongolian noblemen had to appear at the court as a form of punishment. For him, it was important to reach a broad consensus among the Mongolian nobility and to maintain the appearance that their support of the Manchu project was on a voluntary basis. The provocative answer of two Qorčin noblemen to an imperial invitation likewise did not fit into the picture of the Qing emperor of an omnipotent sovereign who graciously bestowed favors on his Mongolian followers and was therefore omitted in later historical accounts.

Legal and administrative codes as collections of imperial decrees are sources of a different type and as a mirror of the political constellations at the time they are much more reliable than literary chronicles of war. However, when reading the Lifanyuan Zeli (Regulations of the Lifanyuan) or the Huidian (Collected Statues) in order to reconstruct the history of the relations between Mongolian rulers and the Qing court, ${ }^{30}$ one cannot presume that these sources are completely without bias. The regulations sometimes rather reflect the ambitious concepts of Lifanyuan officials, who had drafted regulations, which (after meeting with imperial approval) were incorporated into collections of imperial directives.

According to the Administrative Codes, in 1659 the times were long past when it was at the Qorčin nobility's discretion to accept or not accept an imperial invita-

\footnotetext{
27 This was part of the Qianlong emperor's effort to immortalize his triumphs, a goal that was also achieved by the exhibition of commemorative inscriptions and the production of maps and pictures of battles. Elliott, Emperor Qianlong, pp. 100-106.

28 Oyunbilig, Zur Überlieferungsgeschichte des Berichts; Weisers, "Der erste Schriftwechsel zwischen Khalkha und Mandschuren". For the re-interpretation of gift-exchange Heuschert-Laage, "From Personal Network to Institution Buildung”.

${ }^{29}$ Hauer, Huang-Ts'ing K'ai-kuo Fang-lüeh. Die Gründung des Mandschurischen Kaiserreiches, p. 572.

${ }^{30}$ For example in Chia, The Lifanyuan and the Inner Asian Rituals, pp. 64-66.
} 
tion. The Internal Copy of the Lifanyuan Zeli31 relates that in 1648 Mongolian nobles were supposed to appear at the court for the New Year's celebration regularly, and since 1649 the Mongolian nobility who had joined the Qing project was supposed to take turns when coming to the capital to ease the burden for the Lifanyuan to host them. ${ }^{32}$ The Administrative Codes as well as the literary chronicle depict the journeys of Mongolian nobles to the court as inevitable events, which were performed as a matter of routine and were not subject to debate. However, the blunt refusal of the Qorčin princes to accept the invitation makes clear that in the mid-seventeenth century ceremonies of reverence held at the Qing court were still a matter of controversy. Different viewpoints did not necessarily lead to armed resistance but could be negotiated behind the façade of formulas of affection, gratitude and respect.

The letters of the Qorčin nobles who rejected an imperial invitation to come to the court show that Mongols did exercise agency: They competed for influence and status and - even years after their formal "incorporation" - not necessarily confined themselves to the role of the loyal supporters of the Qing imperial house. This aspect is all too easily overlooked. While there is a lot of information on the rules concerning the frequency of visits of Mongolian nobles at the court, the composition of the delegations or the number and value of presents, the question of whether or not the Mongolian side actually accepted an invitation does not come up. Court publications tend to present arrangements for visits of Mongols at the court as an accomplished fact and omit information about the role of Mongols as actors. Archival material can help us to reconstruct the processes of debate, which preceded the establishment of court rituals which are often seen as salient features of Manchu-Mongolian relations during the Qing period. It reminds us that Manchu policies were also met with opposition and regulations were not always accepted as readily as might appear from the perusal of official publications.

\section{References}

Althoff, Gerd 2003, Die Macht der Rituale. Symbolik und Herrschaft im Mittelalter, Darmstadt, Primus.

Bartlett, Beatrice 2006, "Qing Statesmen, Archivists, and Historians and the Question of Memory". In: Archives, Documentation, and Institutions of Social Memory. Essays from the Sawyer Seminar, ed. Francis X. Blouin, William G. Rosenberg, Ann Arbor, The University of Michigan Press, 417-426.

\footnotetext{
31 According to Zhao Yuntian, this work was completed in 1756 (Qianlongchao Neifuchaoben, p. 3). As Dalizhabu emphasizes, it should not be regarded as an early version of the Administrative Statutes of the Lifanyuan, but was rather a draft for the Collected Statutes, which included a section on the Lifanyuan. (Dalizhabu, "You guan Qianlong chao nei fu chaoben").

32 Qianlongchao Neifuchaoben, pp. 66/67. The Collected Statutes of the Kangxi period date this order to the eighth year Shunzhi (1651), see Heuschert, Die Gesetzgebung, p. 114.
} 
Chia, Ning 1993, "The Li-fan Yuan and the Inner Asian Rituals in the Early Qing (1644-1795)”. Late Imperial China 14:1 (1993), 60-92.

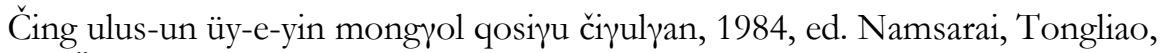
Öbör mongyol-un bayačud keüked-ün keblel-ün qoriy-a.

Dalizhabu 2011, "You guan Qianlong chao neifu chaoben <Lifanyuan zeli>”. In: Zhongguo bianjiang minzu yanjiu 4, ed. Dalizhabu, Beijing, Zhongyang minzu daxue chubanshe, 208-222.

Di Cosmo, Nicola 2012, "From Alliance to Tutelage: A Historical Analysis of Manchu-Mongol Relations before the Qing Conquest", Frontiers of History in China 7,2 (2012), 175-197.

Doerfer, Gerhard 1963, Der Numerus im Mandschu, Wiesbaden, Steiner.

Elliott, Mark C. 2001, The Manchu Way. The Eight Banners and Ethnic Identity in Late Imperial China, Stanford, California, Stanford University Press.

Elliott, Mark C. 2009, Emperor Qianlong. Son of Heaven, Man of the World, New York et al., Longman.

Emich, Birgit, Nicole Reinhardt, Hillard von Thiessen and Christian Wieland 2005, "Stand und Perspektiven der Patronageforschung", Zeitschrift für Historische Forschung 32 (2005), 233-265.

Fang, Chao-ying 1943/44, "Hsiao-tuan Wen Huang-hou". In: Eminent Chinese of the Ch'ing Period (1644-1912), ed. Arthur W. Hummel, 2 vols., Washington, U.S. Government Printing Office, 304-305, (Reprint 1991, Taipei: SMC Publishing).

Hauer, Erich 1926, Huang-'Ts'ing K'ai-kuo Fang-lüeh. Die Gründung des Mandschurischen Kaiserreiches, Berlin, Leipzig, Walter de Gruyter \& Co.

Heuschert, Dorothea 1998, Die Gesetzgebung der Qing für die Mongolen im 17. Jahrhundert anhand des Mongolischen Gesetzbuches aus der Kangxi-Zeit (1662-1722), (Asiatische Forschungen 134), Wiesbaden, Harrassowitz.

Heuschert-Laage, Dorothea 2011, "Defining a Hierarchy: Formal Requirements for Manchu-Mongolian Correspondence Issued in 1636”, Quaestiones Mongolorum Disputatae (QMD) 7 (2011), 48-58.

Heuschert-Laage, Dorothea 2014, "From Personal Network to Institution Building: The Lifanyuan and the Formalization of Manchu-Mongol Relations", History and Anthropology 25.5 (2014), 648-669.

Jagchid, Sechin 1986, "Mongolian-Manchu Intermarriage in the Ch'ing Period", Zentralasiatische Studien des Seminars für Sprach- und Kulturwissenschaft Zentralasiens der Universität Bonn 19 (1986), 68-87. 
Kennedy, George A. 1943/44, "Minggadari”. In: Eminent Chinese of the Ch'ing Period (1644-1912), ed. Arthur W. Hummel, 2 vols., Washington, U.S.

Government Printing Office, 576, (Reprint 1991, Taipei: SMC Publishing).

Ladwig, Patrice, Ricardo Roque, Oliver Tappe, Christoph Kohl, Cristiana Basos 2012, "Fieldwork between Folders: Fragments, Traces, and the Ruins of Colonial Archives", Max Planck Institute for Social Anthropology Working Paper no. 131, Halle/Saale, 27 pages.

Oyunbilig, Borjigidai 1999, Zur Überlieferungsgeschichte des Berichts über den persönlichen Feldzug des Kangxi Kaisers gegen Galdan (1696-1697), (Tunguso Sibirica 6), Wiesbaden: Harrassowitz.

Qianlong chao neifu chaoben $<$ Lifanyuan zeli $>$ 乾隆朝内府抄本 $<$ 理藩院则例 $>$ 2006, ed. Labapingcuo 拉巴平措, Beijing, Zhongguo zangxue chubanshe.

Qing chao qianqi Lifanyuan man meng wen tiben清朝前期理藩院满蒙文题本/

Dayičing gürün-ü ekin üy-e-yin yadaүadu mongyol-un törö-yi jasaqu yabudalun yamun-u manju mongyol ayiladqal-un debter-üd 2010, ed. by B. Oyunbilig et al., 23 vols. + Index, Hohhot, Nei Menggu renmin chubanshe.

Stollberg-Rilinger, Barbara 2004, „Symbolische Kommunikation in der

Vormoderne. Begriffe - Thesen - Forschungsperspektiven“, Zeitschrift für

Historische Forschung 31 (2004), 489-527.

Weiers, Michael 1983, „Der Mandschu-Khortsin Bund von 1626“. In: Documenta Barbarorum. Festschrift für Walther Heissig zum 70. Geburtstag, ed. Klaus Sagaster et al., Wiesbaden, Harrassowitz, 412-435.

Weiers, Michael 1987, „Der erste Schriftwechsel zwischen Khalkha und Mandschuren und seine Überlieferung“", Zentralasiatische Studien des Seminars für Sprach- und Kulturwissenschaft Zentralasiens der Universität Bonn 20 (1987), 106-139.

Weiers, Michael 1994, "Die Historische Dimension des Jade-Siegels zur Zeit des Mandschuherrschers Hongtaiji”. In: Zentralasiatische Studien des Seminars für Sprach- und Kulturwissenschaft Zentralasiens der Universität Bonn 24 (1994), 119-145.

Xin Manhan Da Cidian新满汉大词典, 1994, ed. Hu Zengyi 胡增益, Urumqi, Xinjiang renmin chubanshe. 


\title{
Kontinuität in der Phraseologie des Alt- und Neuuigurischen vom 14. bis zum 20. Jahrhundert
}

\author{
Aysima Mirsultan (Staatsbibliothek, zu Berlin - Preußischer Kulturbesitz)
}

\section{I.}

Das Altuigurische hat deutliche Spuren in verschiedenen Turksprachen hinterlassen. Um die modernen Turksprachen zu verstehen, ist die Kenntnis der altuigurischen Überlieferung notwendig - und umgekehrt: Um die Formen und die richtige Bedeutung im Altuigurischen zu erkennen und zu verstehen, brauchen wir vergleichende Studien. Das moderne Uigurisch gehört zu den Turksprachen, die altuigurische Besonderheiten besonders gut bewahrt haben, Besonderheiten, die in anderen Turksprachen nicht mehr vorkommen.

Die Erforschung altuigurischer Elemente im Neuuigurischen hat bei uigurischen Wissenschaftlern selbst schon in den 50er Jahren begonnen. IBRAHIM MUT' ${ }^{1}$ war der führende Turkologe, der sich als Erster damit beschäftigte und erste Grundlagen für Studien dieser Art in Xinjiang gelegt hat. Auch GENG SHIMIN war auf diesem Gebiet tätig. Er sprach stets mit großem Respekt von MUT'I und nannte ihn „meinen Lehrer, der mir die uigurische Sprache beigebracht hat". Neben GENG SHIMIN ist eine Gruppe uigurischer Sprachwissenschaftler zu erwähnen: XÄMIT TÖMÜR, AMINÄ GAPPAR und MIRSUltAN OSMANOV, die von ihm ausgebildet wurden und in der weiteren Entwicklung dieser Studien eine wichtige Rolle gespielt haben. Während seiner langjährigen Karriere als Lehrer in Pe-

1 IBRAHIM MUT’i (1920-2010). Information zu seinem Leben findet sich bei TAHIRJAN MuHÄMmät 2003. 
king und Ürümči veröffentlichte MUT’I zahlreiche Aufsätze zu Themen wie „Wortpaare im Neuuigurischen“,2 „Irq-Bitig“,3 „Termini in der altuigurischen Dichtung”, „, „Der berühmte Übersetzer Sinqu Säli““5 oder „Kumārajīva und seine Übersetzungstechnik “. ${ }^{6}$ Die von MUT’I stammenden turkologischen Beiträge sind 2007 in einem von seiner Tochter XALIDE MUT'I herausgegebenen Sammelband mit dem Titel Ibrahim Mut'i ilmiy maqaliliri veröffentlicht worden.

In einem Aufsatz, der in den 80er Jahren unter dem Titel „Die wichtigsten Forschungsvorhaben in den uigurischen sprachwissenschaftlichen Studien" publiziert wurde, schreibt MUT'I Folgendes:

„Um die Entwicklung unserer Sprache zu beschreiben, müssen wir sehr intensiv die Sprachmaterialien aus der Vergangenheit untersuchen. Dadurch kann man nicht nur die frübere Lage dieser Sprache besser erkennen, sondern erbält auch eine entscheidende Basis für die Bewertung und für das Studium der Gegenwartssprache."

MUT'I erwartete von seinen Studenten, sich einen guten Überblick über die uigurischen Dialekte zu erarbeiten. Er begleitete sie persönlich bei einer Reihe sich über mehrere Jahre erstreckender Feldforschungen, deren Ziel darin bestand, Materialien zur Dialektologie zu sammeln. Dabei galt sein besonderes Augenmerk altuigurischen Elementen des Wortschatzes, die an bestimmten Orten oder bei bestimmten Gruppen noch im Gebrauch waren. Durch meinen Vater MiRsulTan OsmaNOV, einem Freund und langjährigen Arbeitskollegen, habe ich oft Einschätzungen wie diese gehört, die auf MUT’I zurückgehen:

In der Zukunft werden diese selten verwendeten, aber wichtigen spracblichen Erbstücke durch die Verbesserung der Verkehrsverbindung zwischen Städten und Dörfern langsam verloren gehen. Wir sollen uns beeilen, um diesen Wortschatz, rechtzeitig zu sammeln, und wenn es möglich ist, sollten wir ihn auch verwenden.

In den 60er und 70er Jahren, während der Zeit der Kulturrevolution in China, bestanden kaum Möglichkeiten, sich mit Wissenschaft zu beschäftigen. Aufgrund heute schwer nachvollziehbarer „Gründe“ mussten viele Wissenschaftler ihre beste Zeit im Gefängnis verbringen. IBRAHIM MUT’I selbst war 18 Jahre lang inhaftiert. Erst nach seiner Freilassung konnte er die begonnenen Studien wieder aufnehmen. Als besonders glückliches Erlebnis erwähnte MUT’I oft seine Begegnung mit Annemarie von Gabain - Märyäm Apa, wie sie von den Uiguren genannt wird - im Jahre 1983. Er betonte immer wieder die Bedeutung der neuuigurischen Forschung

\footnotetext{
2 Ibrabim Mut'i ilmiy maqaliliri 2007, 223-239.

${ }^{3}$ Ibrabim Mut'i ilmiy maqaliliri 2007, 413-423.

${ }^{4}$ Ibrabim Mut'i ilmiy maqaliliri 2007, 303-309.

${ }^{5}$ Ein Vortrag, den er 1982 bei dem ersten Symposium der Akademie der Wissenschaften in Ürümči gehalten hat, Ibrabim Mut'i ilmiy maqaliliri 2007, 355-379.

${ }^{6}$ S. Til wä Tärjimä 1984, 3; Ibrabim Mut'i ilmiy maqaliliri 2007, 614-617.

${ }^{7}$ Ibrabim Mut'i ilmiy maqaliliri 2007, 154-173.
} 
für die Studien des Altuigurischen. Im Jahre 1990 sagte er in einem Gespräch mit Mirsultan OSMANOV:

In den 1980er Jahren haben wir Uiguren zwei sehr wertvolle Gäste in unserer Heimat empfangen können. Der eine ist Märyäm Apa, die sich ibr Leben lang mit der altuigurischen Forschung beschäftigte und damit großen Erfolg gehabt hat, der andere ist Gunnar Jarring, der das Neunigurische so geliebt und darüber gearbeitet hat.

Der Besuch Annemarie von Gabains im Jahr 1983 hat in Ürümči und Turfan eine große Bedeutung gehabt. Sie bestand in einer enormen Ermutigung für uigurische Intellektuelle, die sich ihr Leben lang mit diesem Gebiet beschäftigten, doch kaum Unterstützung erfahren haben. Schon haben AMINÄ GAPPAR, ARSILAN ABDULLA ${ }^{8}$ und ABDUREŠIT YAKUP9 eine Reihe altuigurischer Wörter im heutigen Qumulund Turfan-Dialekt identifiziert. Dies ist ein beachtlicher Fortschritt für die Dialektstudien, doch sollten solche Forschungen auch zu weiteren uigurischen Dialekten durchgeführt werden.

Altuigurische Werke wie das Goldglanz-Sütra, das Kšanti kalguluk nom bitig, die Maitrisimit, die Xuanzang-Biographie und andere Werke gehören zur buddhistischen Übersetzungsliteratur. Bei der Übersetzung haben sie nicht nur fremde Wörter entlehnt, sondern auch zahlreiche Neologismen sozusagen „erfunden“. Diese neuen Begriffe scheinen sich aber in der Umgangssprache nicht allzu weit verbreitet zu haben. Dennoch hat sich altuigurischer Wortschatz in erheblichem Maße im Neuuigurischen erhalten, wie sich anhand zahlreicher phraseologischer Begriffe, Redewendungen, Sprichwörter und dergleichen zeigen lässt.

\section{II.}

Im Jahre 1916 wurde erstmalig ein altuigurischer Kontrakt von HANEDA TŌRU10 in der Zeitschift „Tōyō Gakuhō“ veröffentlicht. Seitdem haben zahlreiche Wissenschaftler über altuigurische Vertragstexte gearbeitet, so FENG JIASHENG, ${ }^{11}$ G. J. RAMSTEDT, ${ }^{12}$ GENG SHIMIN, ${ }^{13}$ ISRAPIL YÜSÜP, ${ }^{14}$ J. R. HAMILTON, ${ }^{15}$ L. V. Clark, ${ }^{16}$ LI JINGWEI, ${ }^{17}$ MASAO MORI ${ }^{18}$ METREYIM SAYIT, NOBUO YAMADA, ${ }^{19}$ P. ZIEME, ${ }^{20}$ R. R. ARAT ${ }^{21}$ und andere.

\footnotetext{
8 Abdulla 1985; Abdulla/Hamut 1998.

9 YAKUP 2002.

${ }^{10}$ HANEDA 1916.

${ }^{11}$ FENG 1954; 1960

12 RAMSTEDT 1940.

13 GENG 1978a/b; 1980; 1981; 1984.

14 SAYIT/ YÜSÜP 2000.

15 Hamilton 1969; 1986.

16 CLARK 1975.

${ }^{17}$ Li 1996a/b.

18 MORI 1960.
} 
Während meiner Beschäftigung mit uigurischen Zivildokumenten aus der Zeit von 1876 bis 1949 ist mir aufgefallen, dass Struktur und Sprache in zahlreichen Dokumenten eine bemerkenswerte Ähnlichkeit mit altuigurischen Dokumenten dieser Art aufweisen. Dies hat mich veranlasst, Beispiele für im modernen Uigurischen noch vorhandenen Wortschatz altuigurischer Dokumente zu sammeln. Besonders die Kontrakte aus Turfan gewähren einen unmittelbaren Einblick in die wirtschaftlichen und sozialen Verhältnisse sowie die privaten Lebensumstände der Uiguren unter mongolischer Herrschaft. Bei einem Kontrakt oder Vertrag handelt es sich um eine in Schriftform gebrachte Vereinbarung zwischen mindestens zwei Parteien. Die darin verwendeten Begriffe sollten auch für die ,normale‘ Bevölkerung verständlich sein. Im Folgenden werde ich einen kurzen Überblick über die Ergebnisse meiner vergleichenden Studie vorstellen.

Einer von SIMONE-CHRISTIANE RASCHMANN 22 erstellten Statistik zufolge beträgt die Zahl der bisher bekannten altuigurischen Dokumente 785 Einzeltexte, die in Berlin, Helsinki, Istanbul, Kyoto, London, Paris, Peking, St. Petersburg und Ürümči aufbewahrt werden. Die Sprache der altuigurischen Kontrakte ist im Vergleich zu den altuigurischen buddhistischen Texten, wie soeben bereits angedeutet, durch einen umgangssprachlichen Stil gekennzeichnet, weil sie für das tägliche Leben der uigurischen Bevölkerung bestimmt waren und daher vor allem verständlich zu sein hatten. Selbst durch die Islamisierung haben sich die Strukturen dieser Dokumente wenig verändert. ${ }^{23}$ Wir wollen nun zwei Kontrakte vergleichen, die beide ursprünglich aus Turfan stammen, allerdings aus völlig verschiedenen Zeitperioden. Der erste Vertrag gehört in das 13. Jahrhundert, der zweite datiert aus dem Jahre 1889.

Vertrag aus dem 13. Jh. ${ }^{24}$

1. $\operatorname{koy}(1) n$ yll č(a)xšap(u)t ay üč otuz-ka bizijä y(a)rp

2. yajaka ädgükä ikigükä yoĐlaglıg kunpu kärgäk bolup

3. üstün ögän üzä suvaklıg yeti šıg atl(1)g yemgiči yer-

4. im(i)zni kutadmıška toguru [tom]litu satdım(1)z satıg kunpusın

5. inčä sözläšdim(i)z bokün //// kidini yorır iki učı ken-

6. lig otra tamgalıg üč mı̣ iki ... yüz älig kunpu-

7. ka üzüštüm(ü)z bo kunpunı m(ä)n kutadmıš bitig kılmıš kün

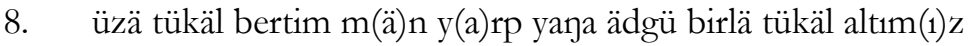

9. boküntä mınča bo yer üzä mın yıl tüm(ä)n künkätägi

\footnotetext{
${ }^{19} \mathrm{Vgl}$. SUK I.

${ }^{20}$ ZIEME 1974; 1975; 1976; 1977; 1980a/b; 1981a/b; 1982; 1992b.

21 ARAT 1964; 1965.

22 RASCHMANN 2009, 7.

${ }^{23}$ Die Richtungsangaben der Grenzen in den Dokumenten aus der Yuan-Zeit haben keine bestimmten Regeln, aber in den späteren Dokumenten ist eine feste Reihenfolge (Ost-West-Süd) vorhanden.

${ }^{24}$ Text und Übersetzung nach SUK II Sa03, Text leicht korrigiert und normalisiert.
} 
10. kutadmıš ärklig bolzun taplasar özi tutzun taplamasar

11. adın kiši<kä> ötkürü satzun. män y(a)rp yạanı ädgünün

12. ičimiz inim(i)z kamız kadašımız ogulumız kızım(1)z ayıtmaz-

13. un istämäzün. ayıtgalı istäg(ä)li sakınsarlar savları

14. yorımazunlar. birök ärklig bäg eši küčin tutup

15. alayın yulayın tesärlär. bo ok ögäntä bo yer t(ä) $)$ jin-

16. čä iki yer berip alzunlar. bo yernin sıčısı öytün

17. yıjak agılık sanlig yer. küntün yıjak y(e)mä agılık

18. sanlıg yer. kedin yıjak y(e)mä agilık sanlig yer. tagtın

19. yınak kičik(i)yä yeri adırar. bo ok yernın tipmsay (?) tay-

20. pukü ögän kidıgınta yazı kičigtä bir ulug atız bir

21. kansan (?) birlä. tanuk kulunčuy tutụ tanuk taz, tanuk

22. kanturmıš. tanuk abıčuk. män sutag1 bizi bolarka

23. ayıtıp bitidim bo tamga män y(a)rp yajanıj ädgünüy ol.

24. bo savta kayusı agısar-biz üč̈r yüz bešär otuz kunpu

25. ičrä kuvpar berüšür biz

26. $[y(a) r] p$ yałatın almıš yernin bitigi

\section{Übersetzung}

„Schaf-Jahr, zwölfter Monat, am Dreiundzwanzigsten.

Da uns, Y(a)rp Yaja und Ädgü, uns beiden, kumpu zum Verbrauch notwendig wurde, haben wir unser am oberen Kanal (gelegenes) bewässerbares und, wie man sagt, 7 sig (als Saatgut umfassendes) yemgiči (?) Landstück dem Kutadmiš korrekt und strikt verkauft.

Über die kunpu als Kaufpreis haben wir uns wie folgt besprochen. Wir haben ihn aus 3250 kunpu festgesetzt, die auf dem Basar von ... gültig sind, an zwei Enden Begrenzungsstoffe und in der Mitte ein Siegel haben. Diese kunpu habe ich, Kutadmišs, am Tag der Ausstellung des Kontraktes vollständig gegeben. Ich, Y(a)rp Yana, und Ädgü, wir haben es vollständig erhalten.

Vom heutigen Tag an bis zu tausend Jahren, zehntausend Tagen möge dieses Land Kutadmiš besitzen. Wenn es ihm gefällt, möge er es selbst behalten, wenn es ihm nicht gefällt, möge er es anderen Leuten weiter verkaufen.

Meine, des Y(a)rp Yạa, und des Ädgü, unsere älteren und jüngeren Brüder, unsere Familien und Familienangehörigen, unsere Söhne und Töchter sollen es nicht in Frage stellen und nicht (zurück)fordern! Wenn sie daran denken, es in Frage zu stellen und (zurück)zufordern, dann sollen ihre Worte nicht gelten. Wenn jemand, die Macht von herrschenden Beamten in Anspruch nehmend, es zurückzukaufen wünscht, dann soll er es zurückkaufen, wenn er zwei Landstücke an eben diesem Kanal und im Wert dieses Landstücks gibt.

Dieses Landstücks Begrenzungen sind: in östlicher Richtung das zur Schatzkammer gehörige Land, in südlicher Richtung ebenfalls das zur Schatzkammer gehörige Land, in westlicher Richtung ebenfalls das zur Schatzkammer gehörige 
Land, in nördlicher Richtung trennt es das Land des Kičikyä. Am Ufer des Tipmsay (?) Taypukü-Kanals dieses Landstücks befindet sich in Yazı Kičig (?) ein großes Feldstück (zwischen Bewässerungsgräben) mit einem kansan.

Zeuge ist Kulunčun Tutuך (Totok?), Zeuge ist Taz, Zeuge ist Kanturmiš, Zeuge ist Abičuk.

Ich, Sutagi Bizi, habe es, dies diktieren lassend, geschrieben.

Dieses Siegel ist mein, des Y(a)rp Yaya und des Ädgü.

Wer von dieser Sache (= diesem Kontrakt) abweicht, der gibt je 325 kunpu als internes Bußgeld (?).

(verso) Das ist der Kontrakt über das von Y(a)rp Yana erhaltene Land.“

\section{Vertrag aus dem Jahr $1889^{25}$}

1. tarixqä b(i)r min üč yüz y(ä)t(ä) qoy yili r(a)b'äl äwwal-nin $y(\ddot{a}) t(a ̈) s i$ düš(ä)nbä küni erdi m(ä)nki t(u)yuqluq toxtä-

2. šäy(i)x-durm(ä)n bu t(ä)riqädä iqrar šär’i qildim bu $j(\ddot{u})$ mlägikä borkoz arigi-daki tört tof takim-ni b(i)lagirih

3. w(ä) b(i)lazulim öz r(i)za wä rägbätim birlä $\dot{\mathrm{g}}(\mathrm{i}) \mathrm{b}(\mathrm{i}) \mathrm{n} \dot{\mathrm{g}}(\mathrm{u})$ rurdin ötüp b(a)y(i)h s(e)h(i)h w(ä) 'aqdi särih birlä m(ä)m(ä)t

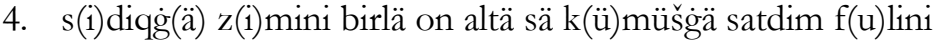
bi baqi q(ä)bz qilib aldim $m(\ddot{a}) z k u r$

5. takdä $\mathrm{m}(\mathrm{e})$ nin hič $\mathrm{h}(\mathrm{ä})$ qim qalmadi b(ä)'dälyärm $\mathrm{h}(\mathrm{i})$ wah $\mathrm{m}(\mathrm{ä}) \mathrm{n}$ w(ä) h(i)wah m(e)nin äwlad aqrbalarimdin b(i)rdä b(i)r k(i)m(ä)rsä

6. čiqib istihqaq $\mathrm{k}(\ddot{a}) l t u ̈ r u ̈ b ~ m(\ddot{u}) l k i t$ d'w(a)y-si qilsä 'andalš(ä)r'i batil w(ä) nas(u)mu' bolsun

7. $\quad \mathrm{w}(\ddot{a}) \mathrm{h}(\mathrm{i})$ wah $\mathrm{m}(\mathrm{e})$ nị äwlad aqrbalarimdin b(i)rdä b(i)r k(i)m(ä)rsä

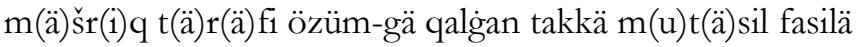

8. $y(\mathrm{e}) \operatorname{rim} \mathrm{f}(\mathrm{a})$ štä š(i)mal $\mathrm{t}(\ddot{a}) \mathrm{r}(\ddot{a}) \mathrm{fi}$ dam(o)llani门 takig̈ä $\mathrm{m}(\mathrm{u}) \mathrm{t}(\mathrm{a})$ sil fasilä ariq

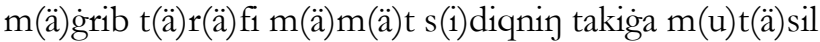

9. $j(\ddot{a}) n u b \mathrm{t}(\ddot{a}) \mathrm{r}(\ddot{a})$ fi kalg(ä)riy huzzar-ul mäjlis $\mathrm{m}(\mathrm{o})$ la kazim imam rozniyaz mu'q(i)n k(e)rim ala' š(ä)y(i)xlar g(u)wah-durlar

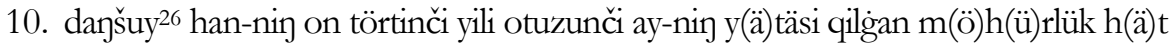

\section{Übersetzung}

„Es war Montag, den 7. Rabi’ al-Awwal 1307 im Jahr des Schafes. Hiermit erkläre ich, Toxtä Šäyix aus Tuyuq, dass ich nach meinem eigenen Willen meine vier Weinreben in borkoz arig mit dem [dazugehörigen] Landstück an Mehmet Sidiq für $16 S a^{27}$ Silber verkauft habe. Ich habe das Geld vollständig erhalten und habe kei-

\footnotetext{
25 吐鲁番文物精粹 2006, 200.

26 guangshuy ist nach chin. guang xu光緒(1875-1908).

27 sä ist die Abkürzung von sär. 1 sär entspricht 50 g. Vgl. UTIL III, 467.
} 
nen Anspruch mehr auf die Weinreben. Wenn meine Kinder oder einer meiner Verwandten es zurückfordern sollten, sollen ihre Worte nicht gelten (sie sollen im Falle einer Rückforderung keinerlei Ansprüche darauf haben). Deshalb habe ich „aus meinem Mund diesen Brief mit Stempel gegeben“ (d. h. ich habe mein Anliegen mündlich vorgetragen und einen Vertrag aufsetzen lassen). Östlich von diesen Weinreben ist mein Landstück mit den übrigen Weinreben, nördlich trennt es der Kanal des Dam(o)lla, westlich trennt es die Weinreben des Mämät Sidiq und südlich trennt es kalg̈(ä)riy (?).

(Huzzar-ul Mäjlis) M(o)la Kazim, Imam Roz(i), Niyaz Muq’in und K(e)rim Alla Šäyix sind die Zeugen.

Das ist ein Kontrakt vom siebten Tag des 30. Monats des vierten Jahres des Kaisers Guangshuy.“

\section{III.}

Das Formular der uig. Schuldurkunden wurde schon vor fast 80 Jahren zum Gegenstand der wissenschaftlichen Forschung. HEINRICH HERRFAHRDT ${ }^{28}$ hatte erkannt, dass diese Schuldurkunden nach einem bestimmten Formular verfasst worden waren, und in einem Aufsatz von 1934 analysiert er die Teile dieses Formulars. Zuerst kommt die „Datierung“ und zum Schluss kommen „Zeugen und Unterschrift". Der von mir oben zitierte Vertrag aus dem 13. Jh. ist ein Verkaufskontrakt, und das Formular weicht etwas ab von dem Formular der Schuldurkunden. Wenn man aber dieses Verkaufsdokument mit dem Verkaufsdokument aus dem Jahre 1889 vergleicht, bemerkt man, dass das Formular sich kaum verändert hat.

Ich will aber hier nicht die Formulare vergleichen, sondern mich interessiert die Kontinuität des Wortschatzes der Kontrakte. Ein nicht geringer Teil des Wortschatzes der altuigurischen Kontrakte aus der Yuan-Zeit ist nämlich auch im NeuUigurischen noch in Gebrauch, wie u. a. der Vertrag aus dem Jahre 1889 zeigt.

\section{IV.}

1) bo yertä biz toř́r yoľ̀ elči üč aka inilärnin soy bayan urug tarng ünüp kim kim-mä bolup cam čarm kilmazun [lar] - „Wenn dieses Land betreffend spätere Nachfahren von uns drei Brüdern Torči, Yolčı und Elči, wer auch immer, erscheinen sollten, so mögen sie keinen Streit beginnen." ${ }^{\text {"29 }}$
aka inilär
neuuig.

(EDPT 170a)

(UTIL I, 111-112)

\footnotetext{
28 HERRFAHRDT 1934.

29 SUK II, Ex02.
} 
2) minta ken är-kä bäg-kä t(e)gmätin ävimni tutup oglum altmiš kayam asirap yorræun „Von jetzt an möge sie nicht zu einem (anderen) Mann gehen, sie soll mein Haus behalten und meinen Sohn Altmıš Kaya pflegen." ${ }^{\text {"30 }}$

$\begin{array}{lll}\begin{array}{ll}\text { ärkä bägkä t(ä)g- } \\ \text { neuuig. ärgä täg- }\end{array} & \text { „heiraten“ } & \text { (EDPT 476a) } \\ \text { idem } & \text { (UTIL I, 247) } \\ \text { äv tut- } & \text { „ein Leben führen; } & \text { (tut- EDPT 451a/b) } \\ & \text { Familie gründen“ } & \end{array}$

In Neuuigurisch bedeutet $\ddot{y}$ tut- „ein Leben führen; eine Familie gründen“ (vgl. UTIL V, 859. ävimni tutup wurde von GENG durch 要管好我家 ${ }^{31}$ yao guan hao wo jia „[sie] sollten sich gut um meine Familie kümmern.“ übersetzt. Es bedeutet nicht, dass man ein Haus „behalten“, sondern dass man sich um die Familie kümmern und das Leben weiterführen soll.

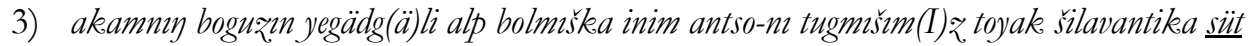
sävinč-i y(e)g(i)rmi stor kümüs alp ogulluk bertim(i) z- ,Weil es schwierig wurde, die Nahrung (für) meinen älteren Bruder zu verbessern, haben wir meinen jüngeren Bruder Antso unserem Blutsverwandten Toynak Šilavanti in Adoption gegeben, wofür wir als Milch-Äquivalent 20 strr Silber erhalten haben.““32

süt sävinči existiert im Neuuigurischen als süt häqqi und bedeutet „Erziehungsgeld und Stillgeld der Mutter" (vgl. UTIL III, 629). Er ist bei den Uiguren in Turfan nach wie vor in Gebrauch. Bei der Heirat sollte nach religiösem Recht die als süt bäqqi bestimmte Summe festgelegt werden. Wenn jemand eine Frau aus Turfan heiratet, verlangen die Eltern der Frau von den Eltern des Bräutigams etwas Geld als „Milch-Äquivalent“. GENG übersetzt es durch 乳水钱 $r$ shui qian, was soviel wie „Milch-Äquivalent“ bedeutet, vgl. GENG 2006, 135. Der Begriff sävinčñ ${ }^{33}$ ist im modernen Uigurisch als söyünčä vertreten, ein „Geschenk als Dankeschön für gute Nachrichten“, vgl. UTIL III, 624. sävinč wurde von GENG als 养育费 yang yu fei „Erziehungsgeld“ in den Index aufgenommen, vgl. GENG 2006, 291.

ogulluk ber- „in Adoption geben” (EDPT 86b)

Im Neuuigurischen bedeutet ogulluq normalerweise „einen Sohn habend”, vgl. UTIL V, 656. Ogulluqqa bär- oder baliliqqa bär- kommen im Alltagsleben bei den Uiguren öfter vor. Es bedeutet dasselbe wie im Altuigurischen.

\footnotetext{
${ }^{30}$ SUK II, WP01.

31 GENG 2006, 217.

32 SUK II, Ad02.

33 sävinč ,joy; joyful news“. EDPT 790a.
} 
4) oglum košay äsän kaya olar ögäy anamız bizkä t(ä)gir alırbiz tep almazun katılmazunlar - „Meine Söhne Košang und Äsän Kaya, sie sollen sie nicht nehmen und sich nicht einmischen, indem sie sagen, dass unsere Stiefmutter zu uns kommt und wir sie nehmen." 34

ögäy ana

neuuig. $\ddot{\text { gg } \ddot{y} y ~ a n a}$
„Stiefmutter“

idem
(EDPT 119b)

(UTIL V, 839)

5) män sudbak ymä bo turmis atlig ogul-n özümdin tugmišca ok sakimp kiz alip berip, yänä

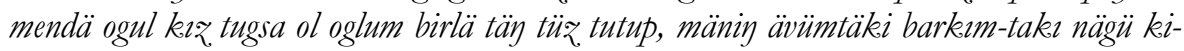
mimni orpak ayng sinuk barm bulguča bulsa näčä oglanlarm bolsa ol oglanlar birlä täy öy ülüs kopı berür män - „Ich, Sudbak, nun werde mir diesen Sohn namens Turmiš wie einen von mir selbst geborenen Sohn vorstellen, ein Mädchen (für ihn) nehmen und (ihm) geben. Ferner: (selbst) wenn von mir Söhne oder Töchter geboren werden sollten, werde ich (ihn) mit diesen meinen Söhnen ganz gleich halten. Was man von mir in meinem Haus und Anwesen an Dingen findet, seien es meine schäbigen, schlechten, zerbrochenen Besitztümer, gebe ich, wieviele meiner Kinder es auch sein mögen, (ihm) mit jenen Kindern zu gleichen Anteilen alles.“35

\section{k1z alıp ber-}

neuuig. qizal- „,ür jemandem ein Mädchen zur Frau nehmen“

(EDPT 124b)

(UTIL IV, 401) „ein Mädchen zur Frau nehmen“"

Bei den Uiguren ist es Pflicht, eine Frau für den Sohn zu finden und sie für ihn zu ,nehmen'.

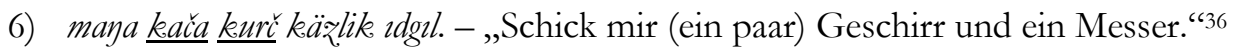
kača kurč
neuuig. qắa-qǔca
,Geschirr"
(EDPT 590a)
idem
(UTIL IV, 33)

Im Neuuigurischen hat qứa allein keine Bedeutung wie čaqa bei bala-čaqa „Familie“.

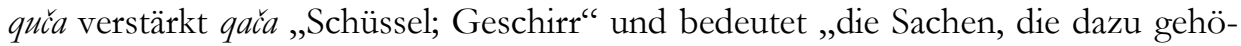
ren".

7) murut v(i)rharka kośmiš ayagka tägimlig kodmiš tös̆äktä orunta ... - „die (von) dem zum Murut-Kloster (gehörenden) ehrwürdigen Košmiš abgelegten Decken und Bettstellen“337

\footnotetext{
${ }^{34}$ SUK II, WP01.

35 SUK II, Ad03.

36 Hamilton 1986, 153-154.

${ }^{37}$ SUK II, Mi12.
} 
töšäk

neuuig. tö̌̆̈̈k

„die Decke“

(EDPT 563b)

idem

(UTIL II, 360)

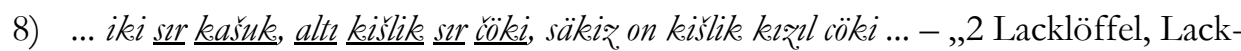
Esstäbchen für 6 Personen, rote Esstäbchen für 80 Personen“338

s1r $^{39}$ kašuk

neuuig. sir qošnq

altı kišlik sır čöki ${ }^{40}$

neuuig. altä kišlik sir čoka
„Zwei Lacklöffel“

idem

„Lack-Esstäbchen

sechs Personen“

idem sir (UTIL III, 679)

für(Ot. Ry. 1414b)

(UTIL II, 689)

9) toyuzynl onunč ay altı y(e)g(i)rmikë män ozmis togrl inim basa togrl biläki alıš beriš tultaginta kitay yalavač alp turmiš olar öskintä tešip alım berim üzüšüumüz. - „SchweinJahr, zehnter Monat, am Sechzehnten. Wegen eines Handels zwischen mir, Ozmı̌̌ Togril, und meinem jüngeren Bruder Basa Togrll haben wir in Anwesenheit von Kitay Yalavač (oder: dem chinesischen Gesandten) und Alp Turmıš, von diesen, miteinander gesprochen und die Abgaben festgesetzt. “"41
alıš beriš
neuuig. eliš beriš
„Handel”
(EDPT 152a)
idem
(UTIL VI, 123-124)

Für die Verwendung dieses Wortpaares vergleiche man: unin bilän bičqandaq eliš berišim yoq - „Ich habe keine geschäftliche Beziehung mit ihm“ oder „Ich habe nichts mit ihm zu tun“.

\section{alım berim}

neuuig. elim berim

$$
\text { „Abgaben“" }
$$

„geschäftliche Beziehung“ (UTIL VI, 124)

In altuigurischen Kontrakten kommt alım berm sehr selten vor. berim alım ist die häufigere.

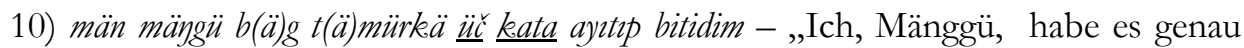
nach dreimaligem Diktat von B(ä)g T(ä)mür geschrieben“"42

üč kata - „dreimal” (EDPT 596a); kat entspricht qat „-mal“ im Neuuigurischen (vgl. UTIL IV, 14).

\footnotetext{
38 SUK II, WP03.

${ }^{39}$ EDPT 842b-843a.

${ }^{40} \mathrm{Vgl}$. cöke: in EDPT 414a.

41 SUK II, Mi04.

42 SUK II, Sa16.
} 
11) satıgin inčä sözläsdimiz - „Den Kaufpreis haben wir so festgesetzt“43

\section{sözläš-}

neuuig. sö̊läs-

$$
\text { „vereinbaren, festsetzen“" }
$$

idem
(EDPT 864a)

(UTIL III, 615)

12) bo kün bašlap bo turta nägümä kalan kavut tütün k(a)prg kodgu umdu borluk äyiz. t(a)rg ür käpäz kavlahk äniz basıg salng nägümä katılmazbiz salmazbiz tep bo budašri baxšika tapšurup bertimiz. - „, Weil dieser Weingarten ursprünglich dem Tur1 gehörte, haben wir (ihn?) dem Meister Budaširi übergeben (mit der Maßgabe), dass von heute an wir uns in keinerlei Steuern des Tur1, seien es kalan, kavut, tütün, kapıg, kodgu, umdu, borluk-äniz, targ, ür, käpäz, kavlallk-äjiz, basig, salng, einmischen und nicht verantwortlich sind. " 44
tapšurup ber-
„übergeben“"
neuuig. tapšurup ber-
idem
(EDPT 447a)
(UTIL II, 7)

13) bo yerkä nečä urug batsa45ikigü t(ä)y üläsip alırbiz - „Wieviel Saatgut in dieses Land eingeht, teilen wir beide zu gleichen Anteilen auf und nehmen es. "46

\section{t(ä)り üläšip ${ }^{47}$ al-}

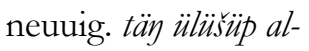

„,zu gleichen Anteilen

aufteilen"

idem
(UTIL V, 891-892)

14) yänä bo näsälärni män tašı yamp kälip turk a töläp bers(ä)rmän män tur borlukn yanturup berürmän - ,Wenn ich, Tašık, bin ich zurückgekehrt, diese Dinge als Rekompens gebe, gebe ich, Tur1, den Weingarten zurück. “48

$\operatorname{yanıp}^{49}$ käl-

neuuig. yenip käl-

töläp ber-

neuuig. töl $\ddot{a}$ -

yanturup ${ }^{50}$ ber-

neuuig. yandur- „zurückkehren“

idem

(UTIL VI, 518)

(EDPT 492b)

(UTIL II, 366)

„,zurückerstatten““

„,zurückgeben“

idem

\footnotetext{
43 SUK II, Sa01.

44 SUK II, Mi20.

45 uig. pat- ,passen, enthalten“ vgl. UTIL I, 605.

46 SUK II, RH11.

47 Vgl. üläs- in EDPT 154a/b.

48 SUK II, Mi19.

${ }^{49} \mathrm{Vgl}$. yan-in EDPT 941b

50 Vgl. yantur- in EDPT 947b.
} 
15) išim onay terk bolsar terk yangay män ${ }^{51}$ - „Wenn meine Arbeit schneller geht, fahre ich auch schneller zurück."

hier oyay ${ }^{52}$ - neuuig. oyay „einfach” (UTIL V, 667-668)

16) sudbak y(e)mä tugmiš ogullar birlä täy tutup kälinläp berip ädgü asirap ogul törüsinčä tutup kulgak boyn tolap ünärmän ketärmän tesär törü yargu yosun birlä ata ya ?miš yazukka tägzün - „Wenn aber Sudbak (ihn) mit den (von ihm selbst) geborenen Söhnen gleich hält, ihn verheiratet, ihn gut versorgt, ihn nach dem Sohn-Gesetz hält und sich (mit) Ohren und Nacken (ihm) zuwendet, (er, d. h. Turmiš) aber sagt „Ich gehe weg!“”, dann gerät er nach dem Brauch von Gesetz und richterlicher Entscheidung in die Sünde, gegen den Vater gesündigt zu haben. "53

GENG $^{54}$ übersetzt den Satz wie folgt:

如我(Sudbag)把他视同我子一样看待, 为其娶妻, 并依照养子法善待, 关心他, 而他仍然要离开的话, 那就依照法律, 他将犯不孝罪。一, ,Wenn aber ich (Sudbak) ihn mit meinen Söhnen gleich halte, ihn verheirate, ihn nach dem Sohn-Gesetz halte, ihn gut versorge, aber er (der Sohn) mich (Sudbak) trotzdem verlässt, dann gerät er nach dem Brauch von Gesetz und richterlicher Entscheidung in die Sünde, gegen den Vater gesündigt zu haben.“

kulgak boyın tola-55 ,sich (mit) Ohren und Nacken (ihm) zuwenden“

boyun tolga- bedeutet in Neuuigurischen ,jemandem den Rücken zuwenden, jemandem die kalte Schulter zeigen“ (vgl. UTIL II, 277). Daher würde ich den Satz wie folgendes übersetzen: „Wenn aber Sudbak (ihn) mit den (von ihm selbst) geborenen Söhnen gleich hält, ihn verheiratet, ihn gut versorgt, ihn nach dem SohnGesetz hält, aber er (der Sohn) sich ihm (Sudbak) mit Ohren und Nacken zuwendet und sagt: „Ich gehe weg!“", dann gerät er nach dem Brauch von Gesetz und richterlicher Entscheidung in die Sünde, gegen den Vater gesündigt zu haben.“

17) bo tämir kayaka ton satıgı iki yarm bözni bergil osal bolmazun ${ }^{56}$ - „Gib Tämir Kaya zweieinhalb (Stück) Baumwollstoff“"

osal bolma-

neuuig. osal bol- „nachlässig werden“

idem

(UTIL V, 648)

\footnotetext{
51 Hamilton 1986, 107-108.

$52 \mathrm{Vgl}$. oyay in EDPT 191b.

53 SUK II, Ad03.

54 GENG 2006, 137-138.

55 tola $<$ tolga- ,to twist, wrap round”. Vgl. EDPT 497a.

56 Clark 1975, 98.
} 
18) ... 「sa]vning tovlisı yomz[un] - „Das tovlu (?) des Wortes möge gelten!“ savni tovlisı „das Prinzip [dieser] Rede" 57

neuuig. gäpnin dawlisi „der Sinn dieser Rede“. Die Losung und die Übersetzung in SUK muss korrigiert werden. tovli ist ein altes Lehnwort aus dem Chin., das schon in der Maitrisimit (83 v 27) belegt ist. Es geht zurück auf chin. dao li 道理 „,Grundsatz, Prinzip" und existiert noch im Neuuig. in der Form dawli, z. B. in der Redensart bu gäpniy dawlisi bar, „diese Rede hat schon einen Sinn“.

19) yeti küntin kečsär män kaytso tu igäläp alıp kün ägsükin köni berürmän - „Wenn (die Krankheit) sieben Tage überschreitet, bin ich, Qaytso Tu, der ihn besitzt und übernimmt, und ich gebe korrekt, was ihm (jeden) Tag fehlt. “58

igäläp al„besitzen und übernehmen"

neuuig. igälliwal-/ igälläp al- idem

(UTIL VI, 329)

Die Kombination Hauptverb + al- hat eine schwache Bedeutung, oft im Sinne des Dativs ethicus („,etwas für sich selbst tun“). In dem etymologischen Wörterbuch für Uigurisch (UTIL) konnten wir Kombinationen wie igäläp al-, üläsip al(S. 8), tapšurup ber- (S. 8), töläp ber- (S. 9), yandurup ber- (S.9), yamp käl- (S. 8), ogulluk ber- (S. 3), kiz alip ber- (S.7) nicht finden. Solche Verbkombinationen werden im Neuuig. aber oft verwendet.

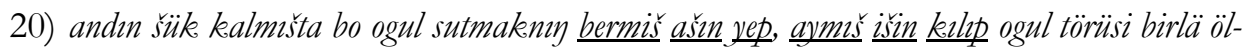
ginčä köni bišrg tapınzun - „Nachdem er zur Ruhe gekommen sein wird, soll dieser Sohn die von Sutmak (= Sudbak) gegebenen Speisen essen, die von ihm befohlenen Arbeiten verrichten und so nach dem Sohn-Gesetz, bis er (d. h. Sudbak) stirbt, korrekt und eifrig dienen. "59

Man hört öfter bei den Uiguren die Maxime: ularnin bärgän ešini yäp, digän išini qilg̈in „Du musst die Speise essen, die sie Dir geben, und die Arbeiten verrichten, die sie Dir befehlen!“ Viele Eltern erziehen ihre Kinder mit solchen Maximen, damit Sie später vernünftig sind und sich daran gewöhnen, bei ihrem Arbeitgeber zu bleiben.

Wie man sieht, zeigt sich die Kontinuität zwischen dem Alt-Uigurischen und dem Neu-Uigurischen vor allem in Idiomen oder festen Redewendungen. Es überrascht daher nicht, wenn man auch bei Sprichwörtern eine besondere Kontinuität beobachten kann. HAMILTON hat im Jahre 1986 eine Liste von sechs alttürkischen Sprichwörtern publiziert, die nahezu alle fast wörtlich noch im Neu-Uigurischen existieren: ${ }^{60}$

\footnotetext{
${ }^{57}$ Li übersetzt es 话之道理hua zhi dao li „das Prinzip des Wortes“. Vgl. Li 1996a, 62.

58 SUK II, P101.

59 SUK II, Ad03.

${ }^{60}$ Vgl. Hamilton 1986, 94-96.
} 
kurug tagda kaplan bolmaz, kudug suvinda baliq bolmaz.

neuuig. quruq tagida qaplan bolmas, quduq süyidä beliq bolmas - „Im kahlen Gebirge gibt es keine Leoparden, im Wasser des Brunnens findet man keine Fische.“

ken ton opr(a)maz ken(ä) šlig bilig art(a)maz. ${ }^{61}$

neuuig. key ton uprimas keyäslik is buzulmas - „Ein breiter Mantel wird kaum zerreiBen, gemeinsames Tun nur schwer misslingen.“ (vgl. TTD II 2008, 560; 954-9. III 489-18)

altun s(a)r(1)gita körü isič k(a)rası yeg, yürün k(ü)müšda körü ayak tolus1 yeg. neuuig. altun seriqiga körä qazanniy qarisi yax̌̌si, aq kümüškeä körä tolgan tawaq yax̌̌i „Der schwarze Ruß des Topfes zählt mehr als goldgelbe Farbe. Ein voller Teller wiegt mehr als weißes Silber.“"

käyäk näčä yol bilsä avčı $\mathrm{a}<\mathrm{n}>$ ča al bilir.

neuuig. keyik nä̌čä yol bilsä, owč sunčä amal bilär - „Wie viele Wege die Rehe auch kennen, umso mehr Mittel weiß der Jäger.“

bilgä näčä $\mathrm{k}(\mathrm{a}) \mathrm{r}$ ssa bilig sav1 yaク(1)lmaz, arkar näčä $\mathrm{k}(\mathrm{a}) \mathrm{r} 1 \mathrm{sa} \mathrm{k}(\mathrm{a})$ ya yolı yan(1)lmaz.

Neuuig.: bilimlik kiši qančä qerisa bilimi šunčä xataliqsiz bolur. arqar qančä qerisa qiyaliq yolda adašma: ${ }^{62}$, „Je älter der Weise, umso verlässlicher ist sein Rede. Je älter ein Wildschafsbock wird, umso seltener wird er sich verlaufen."

Im obigen Beitrag wurden nur einige Beispiele vorgestellt, die eine auffallende Ähnlichkeit des altuigurischen und neu-uigurischen Wortschatzes belegen. Ein näherer Vergleich des Lexikons dürfte weitere Belege zutage fördern, die eine bemerkenswerte Kontinuität der Denk- und Ausdrucksweise aufzeigen.

\footnotetext{
61 key(ä)šlig bilig ardimas key ton uprumas. Vgl. Menges 1943, 166-25.

62 yamılma- entspricht im heutigen Uigurischen yeyilma- und bedeutet „nicht verlieren“.
} 


\section{Bibliographie und Abkürzungen}

EDPT

QUYW

SUK

TTD

UTIL s. Clauson (1972)

s. Sayit/Yüsüp (2000).

s. Oda/Zieme/Umemura/Moriyasu (1993).

s. Tursun/Osmanov/Rozi (2008).

s. Yakup/Geyrurani u. a. (1990-1999).

ABDULLA, ARSILAN (1985): Hazirqi zaman uygur tilinin qumul šewisi tog்risidiki däsläpki izdiniš. In: Til wä Tärjimä (šinjiạ aptonom rayonnin qurulganliqinin 30 yilliqini täbrikläš munasiwiti bilän čiqirilgan alahidä san), 62-112.

ABDUlLA, ARSILAN/PÄRIDÄ HAMUT (1998): Qumul šewisidiki qädimqi sözlär tog̣risida izdiniš 2. In: Til wä Tärjimä I, 15-21.

ARAT, R. R. (1964): Eski Türk hukuk vesikalar1. In: Journal de la Société FinnoOugrienne 65 (1), 11-77.

- (1965): Among the Uighur documents, II. In: UAJb 36, 263-272.

CLARK, LARRY V. (1975): Introduction to the Uyghur civil documents of East Turkestan (13 $3^{\text {th }}-14^{\text {th }}$ cc.). Dissertation of Indiana University (Bloomington). Ph. D. University Microfilms International, Ann Arbor (Michigan), London.

ClAUSON, SIR GERARD (1972): An etymological dictionary of pre-thirteenthcentury Turkish. Oxford. [Zitiert als: EDPT]

FENG JIASHENG (1954): 元代畏兀儿文契约二种 Yuandai weiwuer wen qiyue er zhong. In: Lishi Yanjiu 1, 119-131.

- (1960): 回鹘文契约二种 Huihuwen qiyue er zhong. In: Wenwu 6, 32-34.

GENG SHIMIN (1978a): 两件回鹘文契约的考释 Liang jian huihuwen qiyue de kaoshi. In: Zhongyang Minzu Xueyuan Xuebao 2, 43-49.

- (1978b): 回鹘文摩尼教寺院文书初释 Huihuwen monijiao siyuan wenshu chushi. In: Kaogu Xuebao 4, 497-516.

- (1980): 几件回鹘文文书译释 Ji jian huihuwen wenshu yishi. In: Wenwu 5, 83-84.

- (1981): 两件回鹘文买卖奴隶文书的考释 Liang jian huihuwen maimai nuli wenshu de kaoshi. In: Minzu Yuwen Lunji, 272-291.

- (1984): A study of two Uighur contracts of the Yuan dynasty (1271-1368). In: Zentralasiatische Studien 17, 7-18. 
- (2006): 回鹘文社会经济文书研究Huibuwen shebui jingji wenshu yanju (Research on Social economic Uyghur documents). Peking.

HANEDA, TŌRU (1916): 回鹘文女子売渡文書 Kaikotsu-bun joshi uriwatashi monjo. In: Tōyō Gakuhōo 6 (2), 272-276.

HAMILTON, JAmes Russel (1969): Un Acte ouigour de vente de terrain Provenant de Yar-khoto. In: Turcica 1, 26-52.

- (1986): Manuscrits ouïgours du IX-X siècle de Touen-houang, I-II. Paris.

HERRFAHRDT, HEINRICH (1934): Das Formular der uigurischen Schuldurkunden. In: Zeitschrift für vergleichende Rechtswissenschaft 48, 93-103

IMIN TURSUN/MIRSULTAN OSMANOV/SABIT ROZI et al. (2008): Türki tillar diwani I, II. Ürümči. [Zitiert als: TTD].

LI JINGWEI (1996 a): 回鹘文社会经济文书研究Huibuwen shebui jingji wenshu yanjiu (Research on the socialeconomic Uyghur documents). Ürümči.

- (1996 b): 吐鲁番回鹘文社会经济文书研究Tulufan buibuwen shebui jingii wenshu yanjiu (Research on the Social economic Uyghur documents from Turfan). Ürümči.

LIU GE (2000): 回鹘文契约文书初探 Huibuwen qiyue wenshu chutan. Taibei.

METREYIM SAYIT/ISRAPIL YÜSÜP (2000): Qädimqi uyg்ur yeziqidiki wäsiqilär. Ürümči [zitiert als: QUYW].

MENGES, KARL HeIRICH 1943: Volkskundliche Texte aus Ost-Türkistan. II: aus dem Nachlass von N.Th. Katanov herausgegeben. Berlin.

MirSUlTAN OSMANOV/LI JINGWEI/JIN SHANGYI (1999): On an ancient Uyghur Yarkand document in Arabic script. In: Turkic Languages 3, 43-55.

MORI, MASAO (1960): ウイグル葡萄园売渡文書 Uiguru budōen uriwatashi monjo. In: Tōyō Gakuhō 42, 22-50.

MUT'I, XALIDE (2007): Ibrahim Mut'i ilmiy maqaliliri. Beyjing.

OdA, Juten/Peter Zieme/Hiroshi Umemura/TAKaO MOrIYASu (1993): ウ イグル文契约文 書集成 (Uiguru-bun keiyaku monjo shūsei) Sammlung nigurischer Kontrakte I-III. Ōsaka [zitiert als: SUK].

RAmstedt, Gustaf J. (1940): Four Uigurian Documents. In: C. G. Mannerheim: Across Asia from West to East in 1906-1908. II, Helsinki, 1-12.

RASCHMAnN, SimOne-Christiane (2007): Alttürkische Handschriften. Teil 13.

Dokumente. Teil. Stuttgart (VOHD 13, 21). 
- (2009): Alttürkische Handschriften. Teil 14. Dokumente. Teil 2. Stuttgart (VOHD $13,22)$.

RÖHRBORN, KLAUS (2010): Uigurisches Wörterbuch. Sprachmaterial der vorislamischen türkischen Texte aus Zentralasien. I. Verben, Band 1: abäzüglä-. Neubearbeitung 2010. Stuttgart.

TAHIRJAN MUHÄMMÄT (2003): Haz̧irqi zaman uyg்ur tilšnasliqiniๆ bašlamčcisi, ataqliq jama'ät ärbabi-Ibrahim Mut'i. In: Til wä Tärjimä 1; Ibrahim Mut'i Ilmiy maqaliliri 2007, 753-760.

吐鲁番文物精粹 (Selected treasures of Turfan relics).Tulufan wenwu jingcui. Shanghai 2006, S. 200.

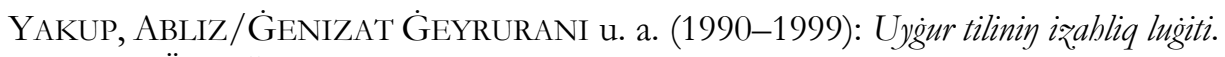
I-VI. Ürümči. (weitere Autoren: Zayit Hewil, Ismayil Qadir, Hemdulla Abduraxman, Abliz Emet, Perhat Nur) [zitiert als: UTIL].

YAKUP, ABDURISHID (2002): Old Uyghur lexemes preserved in the Turfan-Qomul dialect of Uyghur-the case oft two „Erntesegen“ texts. In: Turkic Languages 6-1, 79-123.

ZIEME, PETER (1974): Ein uigurischer Landverkaufsvertrag aus Murtuq. In: AoF 1, 295-308.

- (1975): Ein uigurischer Text über die Wirtschaft manichäischer Klöster im uigurischen Reich. In: L. LIGETI (ed.): Researches in Altaic languages. Budapest, 331-339.

- (1976): Zum Handel im uigurischen Reich von Qočo. In: AoF 4, 235-249.

- (1977): Drei neue uigurische Sklavendokumente. In: AoF 5, 145-170.

- (1980a): Uigurische Pachtdokumente. In: AoF 7, 197-245.

- (1980b): Ein uigurischer Leihkontrakt über Weizen. In: AoF 7, 273-275.

- (1981a): Research on Uigur documents since 1975. In: Journal Asiatique 269 (1/2), 55-61.

- (1981b): Uigurische Steuerbefreiungsurkunden für buddhistische Klöster. In: AoF 8, 237-263.

- (1982): Ein uigurisches Familienregister aus Turfan. In: AoF 9, 263-267.

- (1992b): Eine uigurische Hausverkaufsurkunde aus Qočo. In: AoF 19 (2), 359-371. 



\section{The Symbolism of "čarayana", "tamarisk", and "tabilqai" occuring in Mongolian customs}

T. Namjil (Xinjiang Academy of Social Sciences, Urumchi - Research Institute for Ethnic Culture) 
承

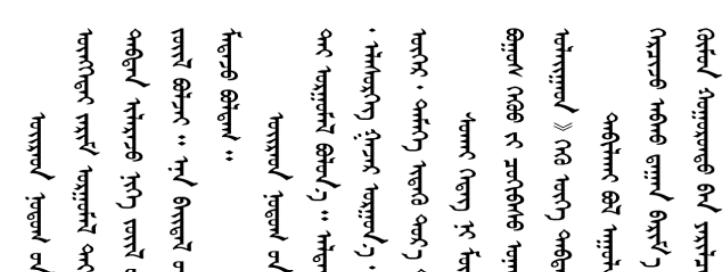

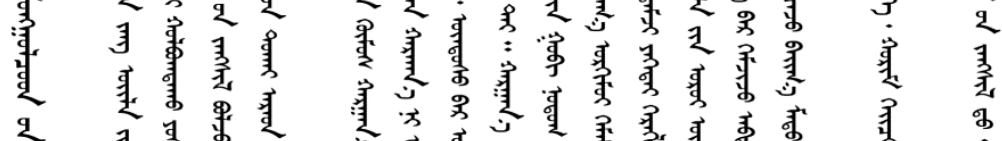

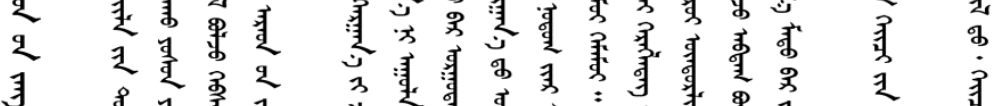

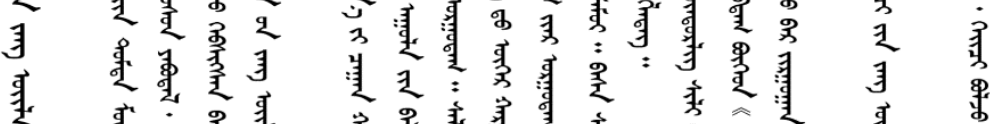

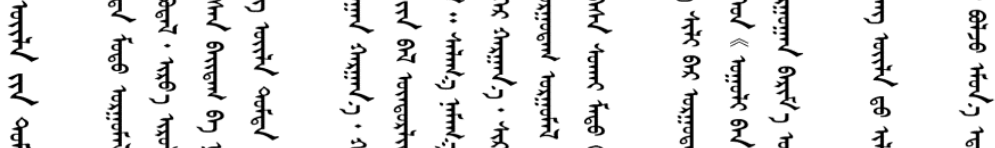

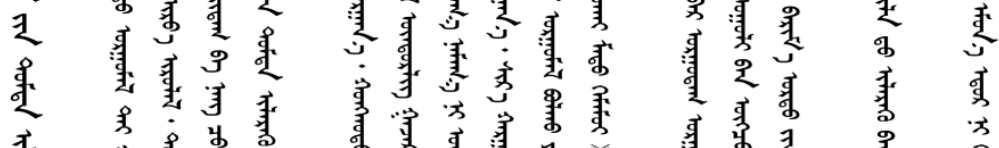

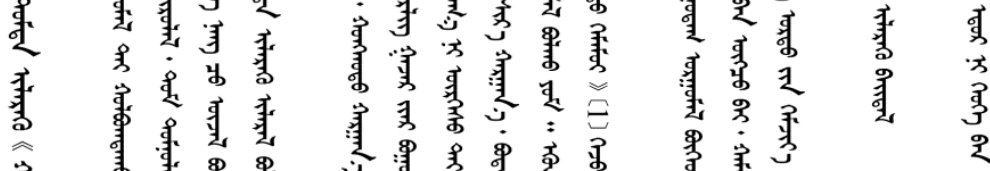

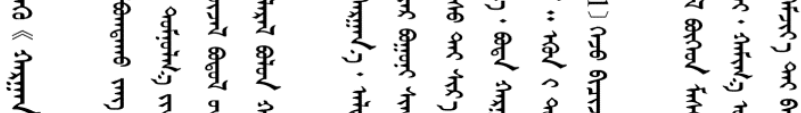

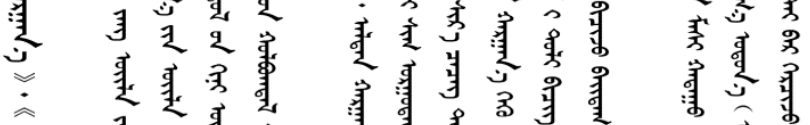

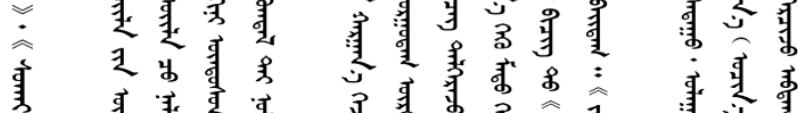

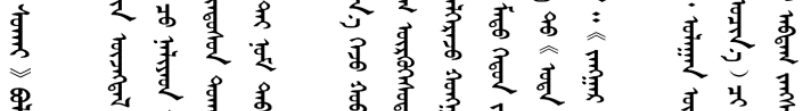

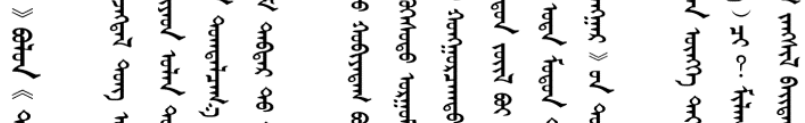

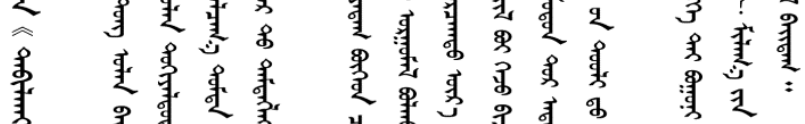

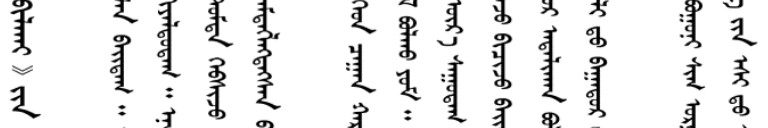

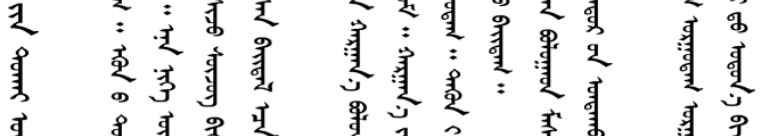

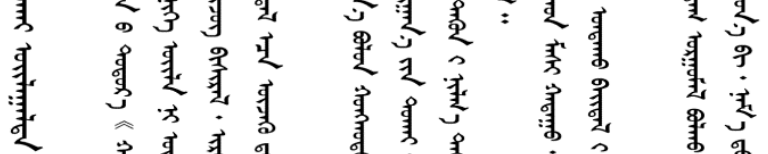

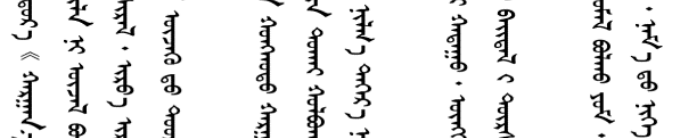

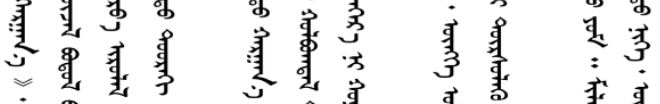

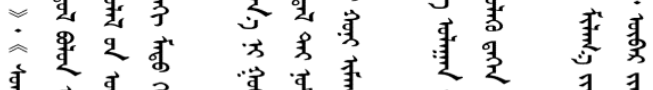

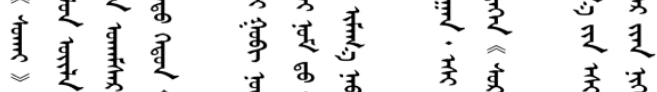

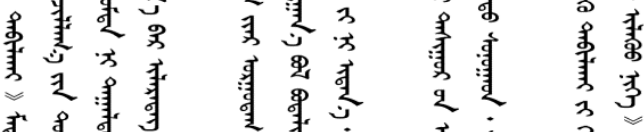

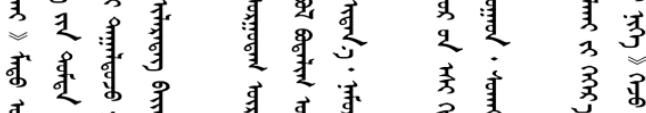

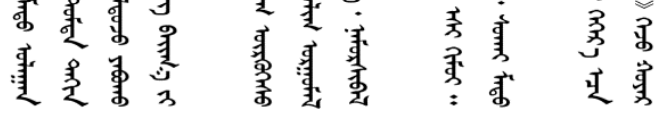

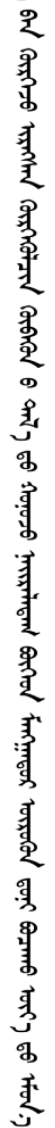




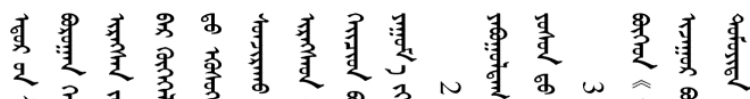

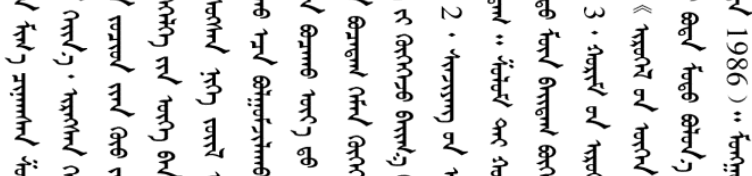

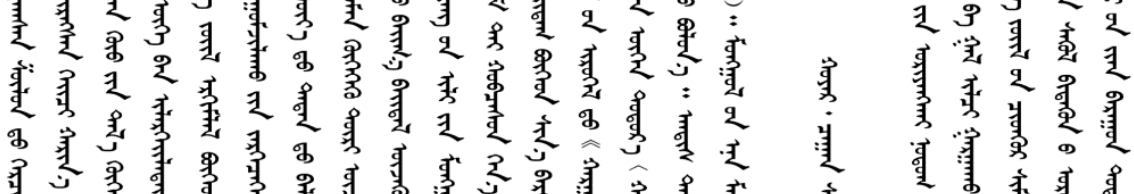

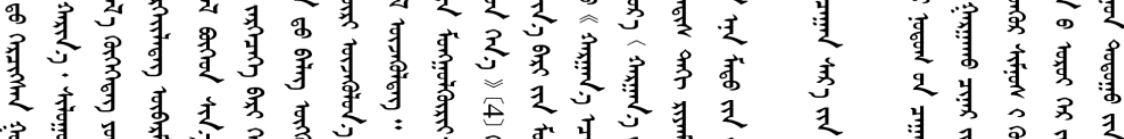

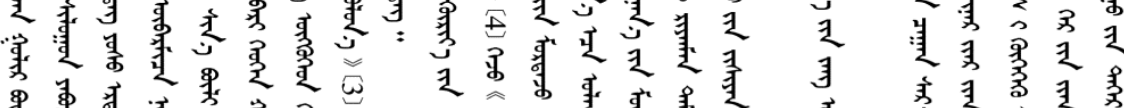

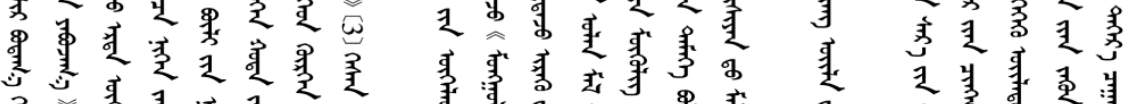

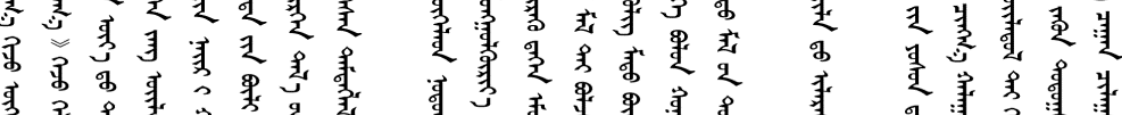

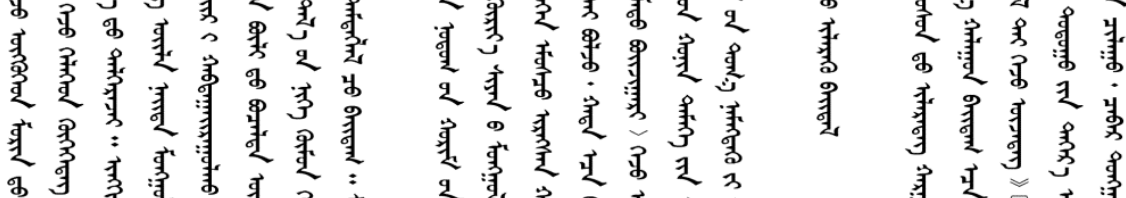

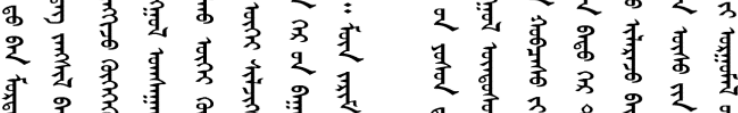

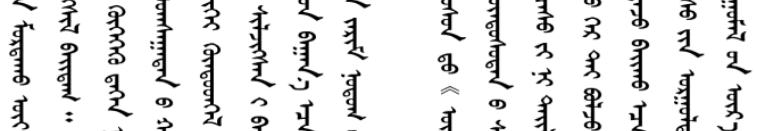

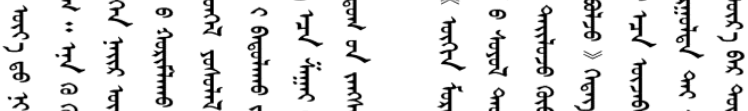

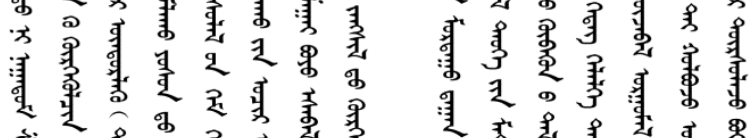

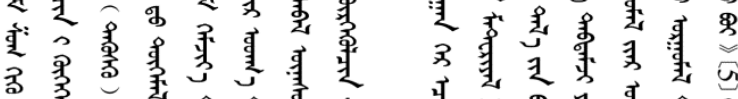

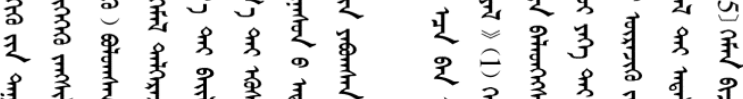

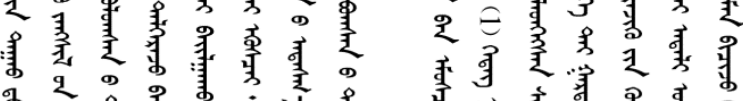

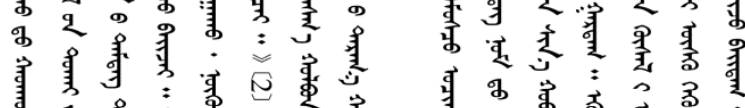

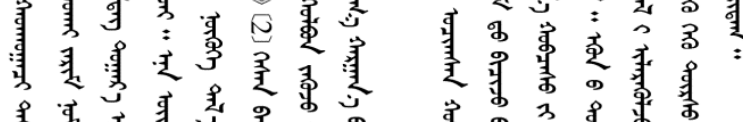

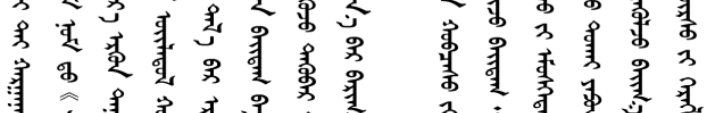

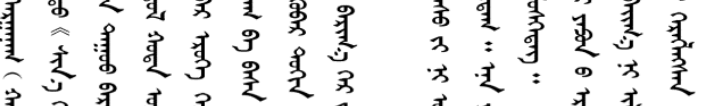

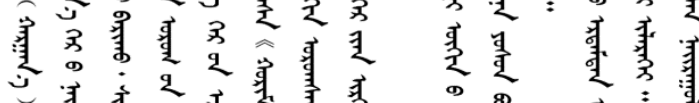
肃合是是

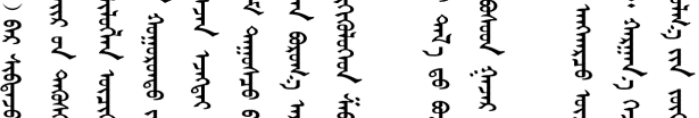

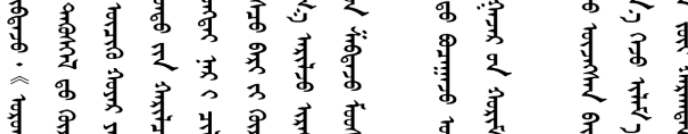

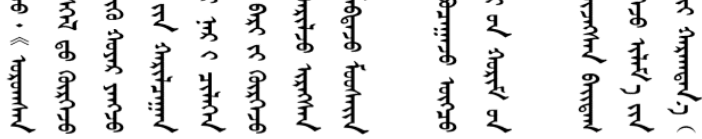

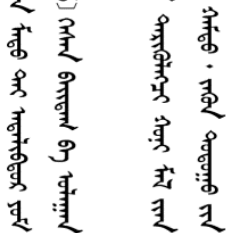




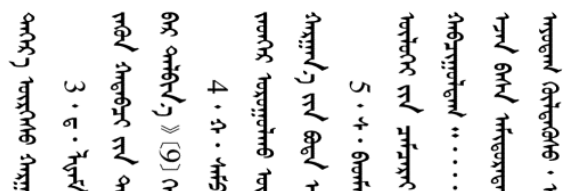

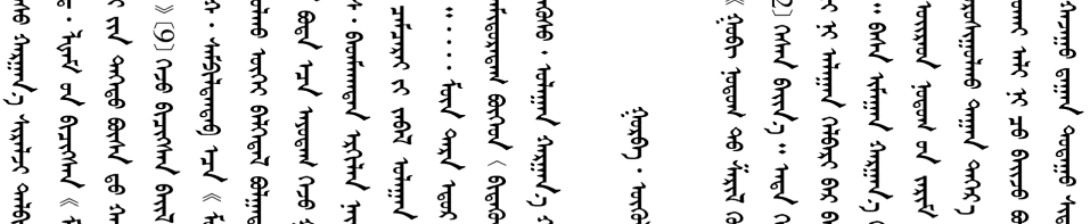

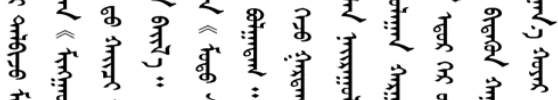

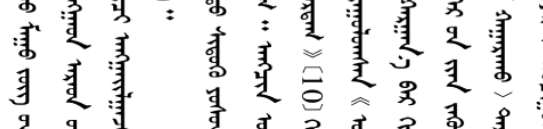

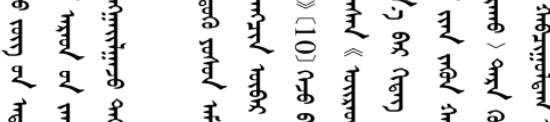

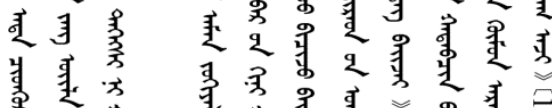

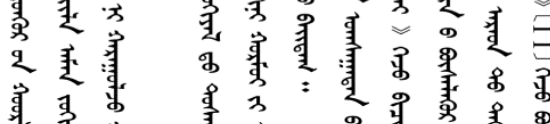

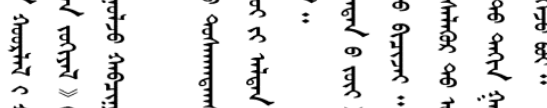

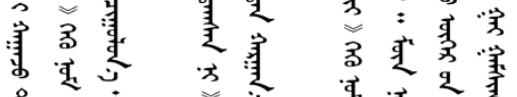

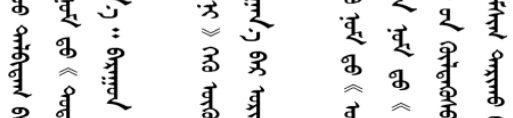

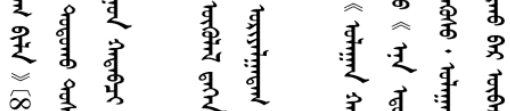

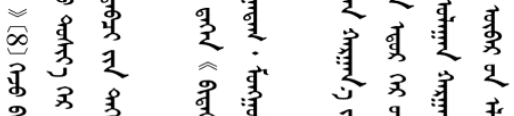

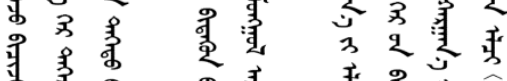

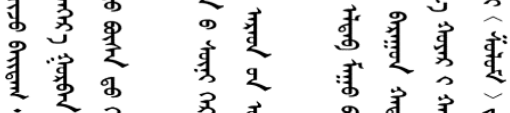

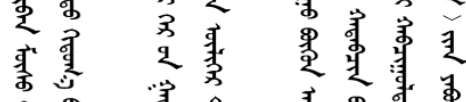

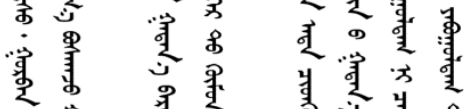

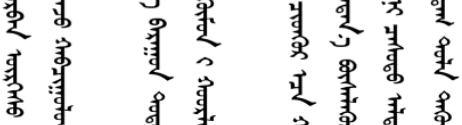

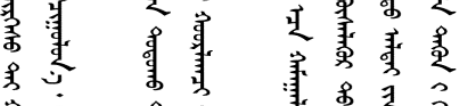

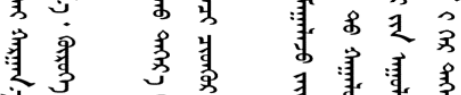

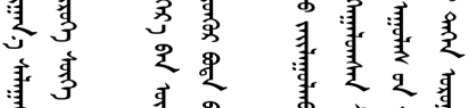

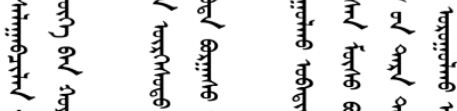

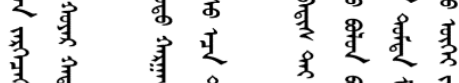

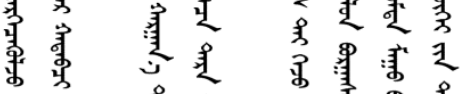

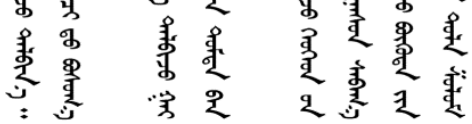

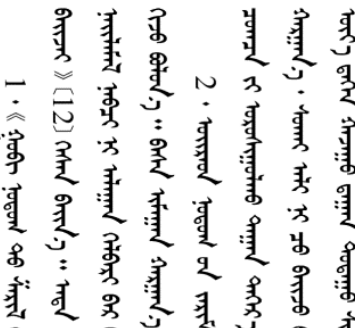

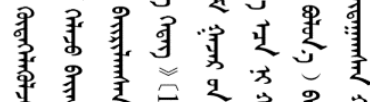

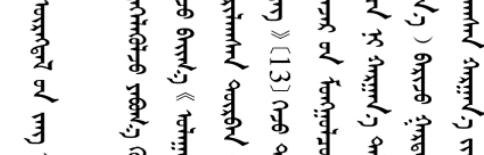

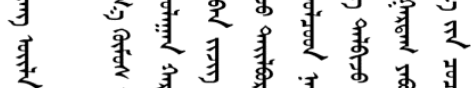

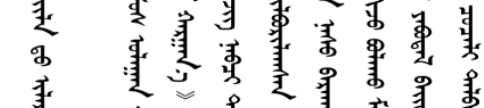

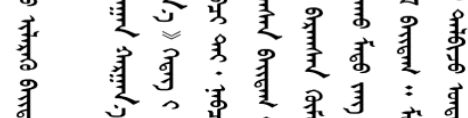

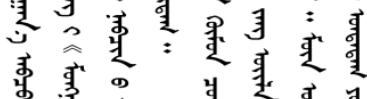

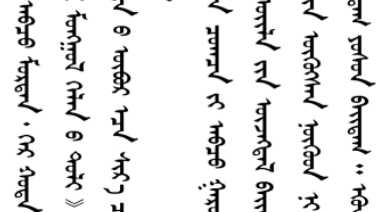

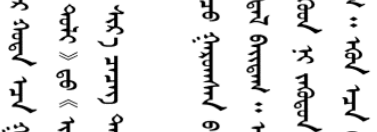

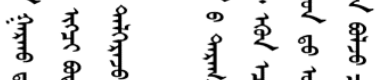

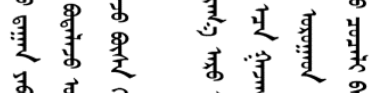

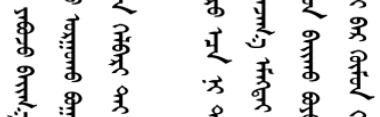

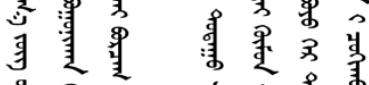

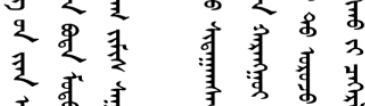

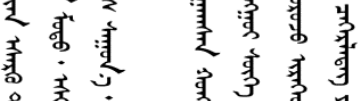

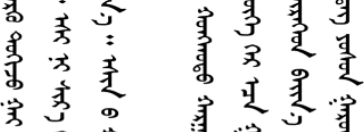

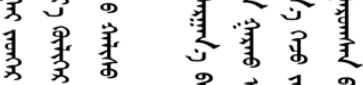

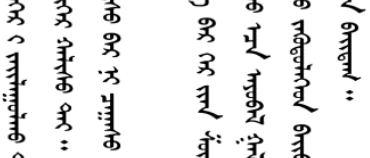

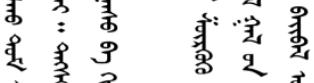

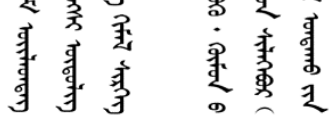




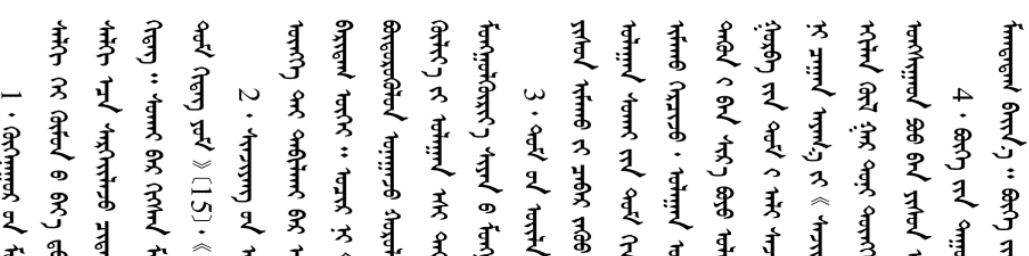

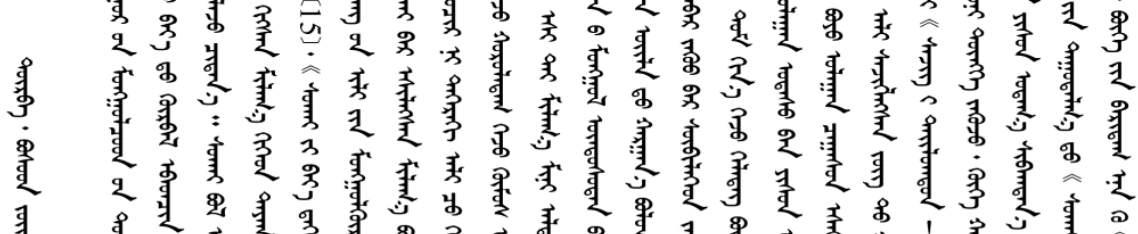

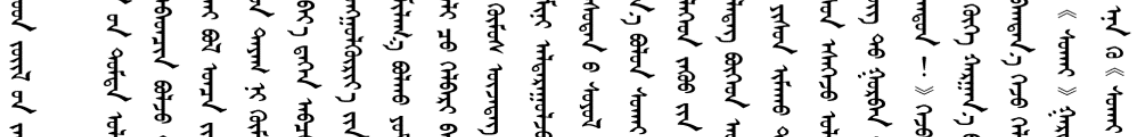

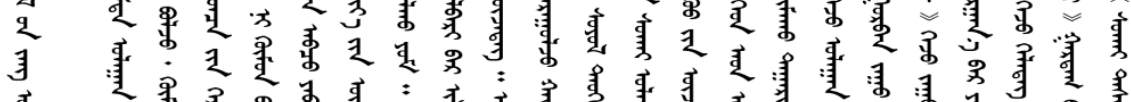

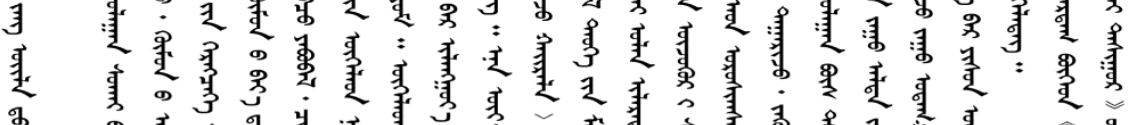

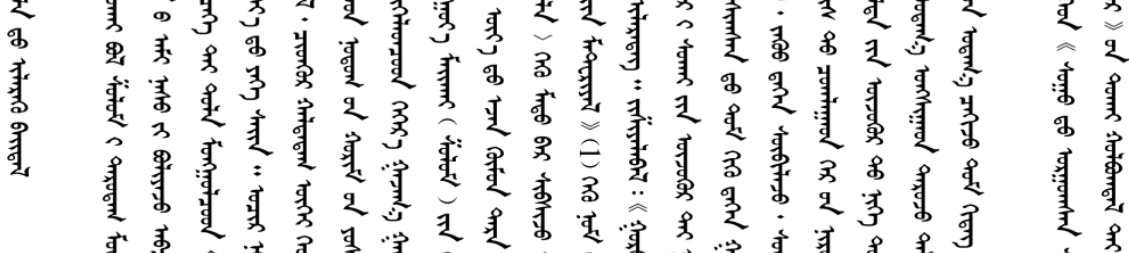

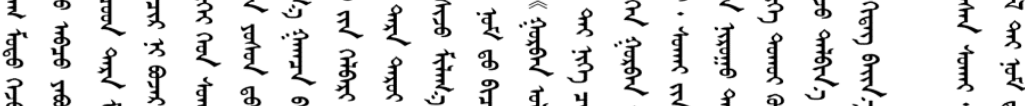

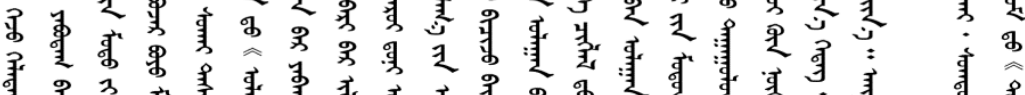

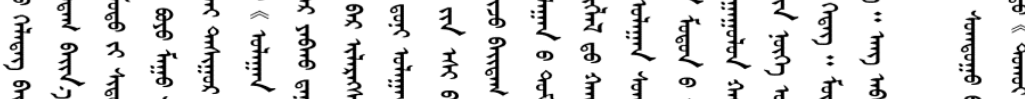

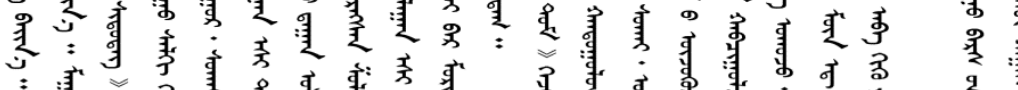

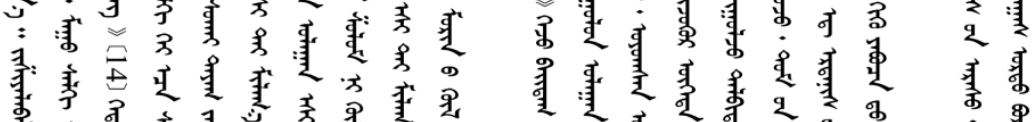

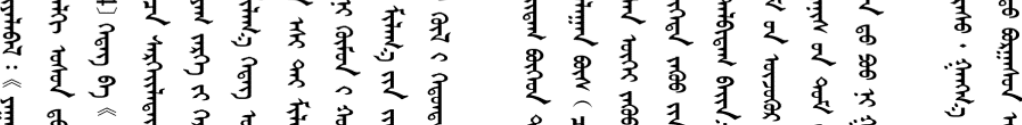

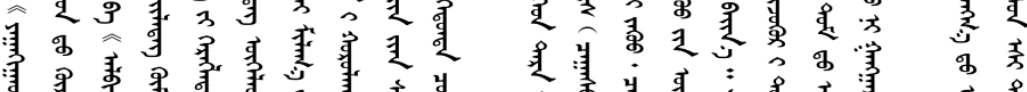

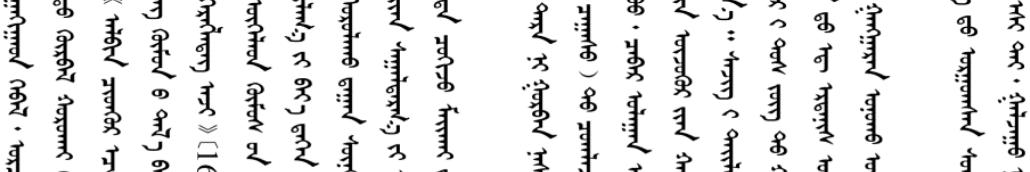

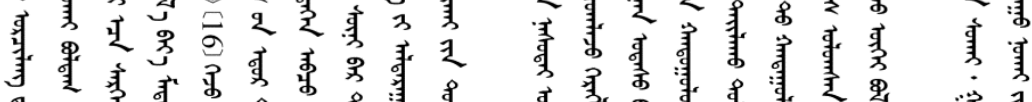

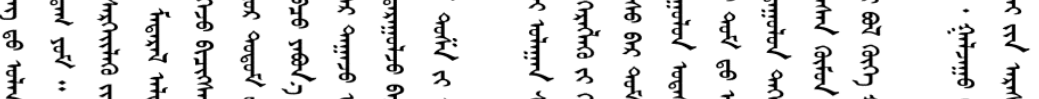

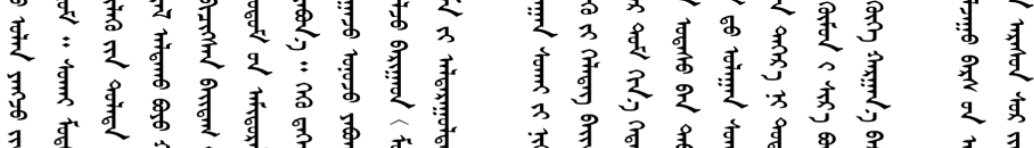

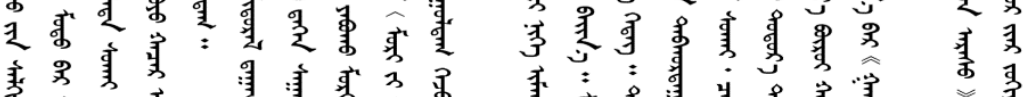

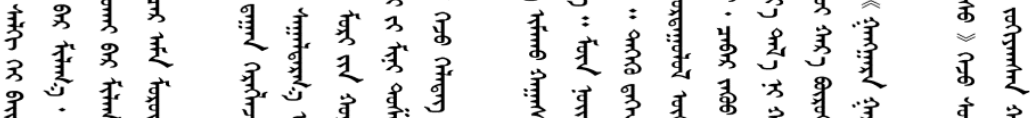

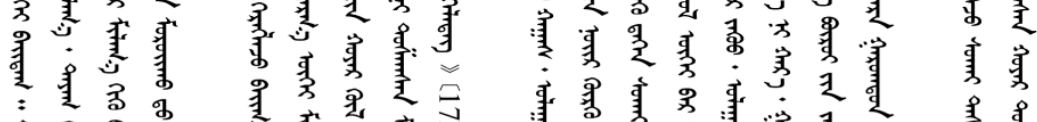

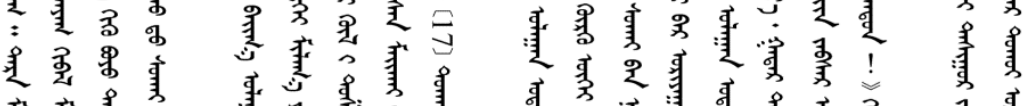

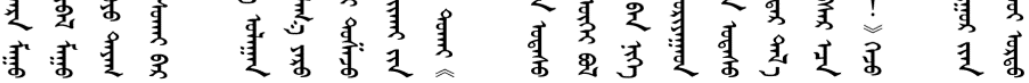




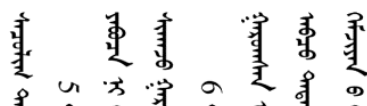

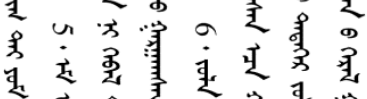

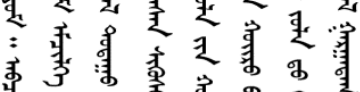

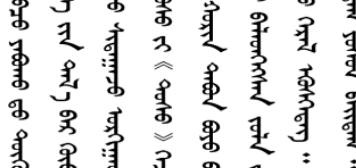

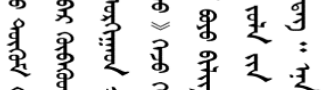

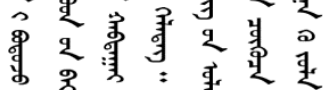

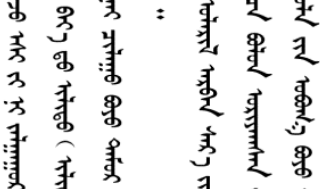

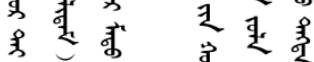

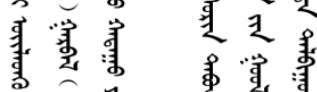

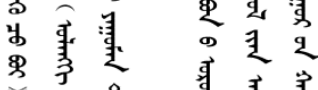

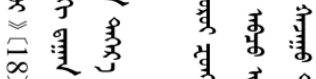

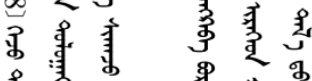

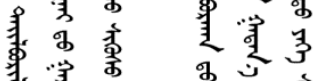

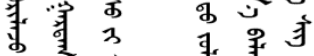

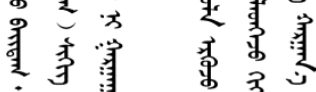

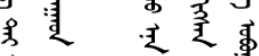

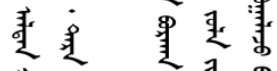

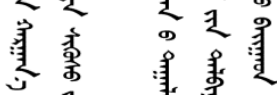

果等透

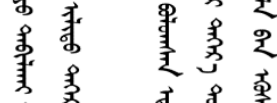

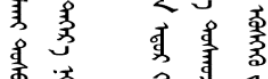

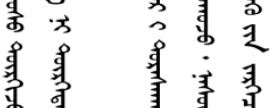

ब亲高章

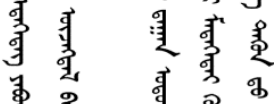

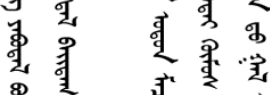

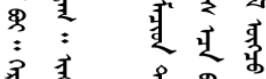

柔素旁秀素

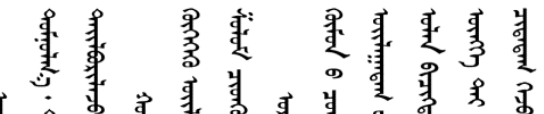

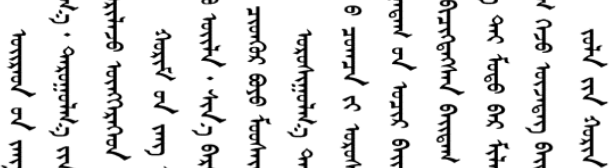

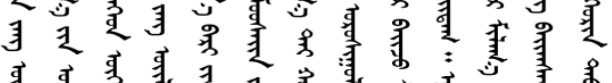

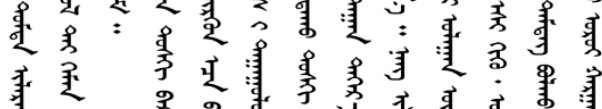

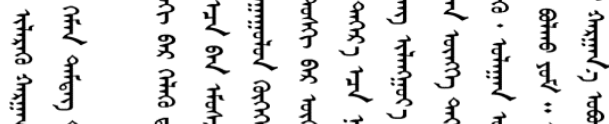

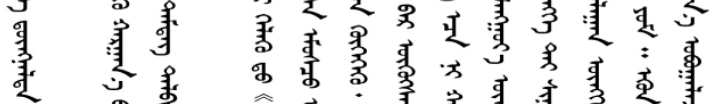

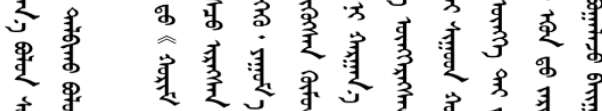

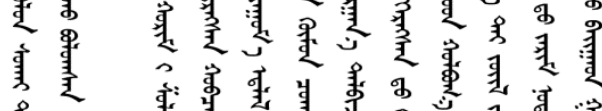

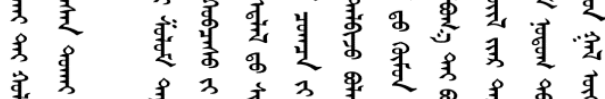

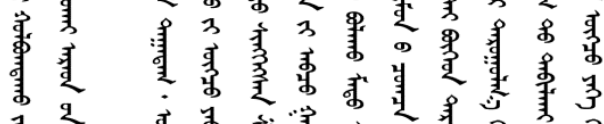

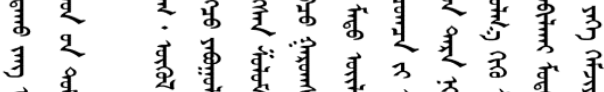

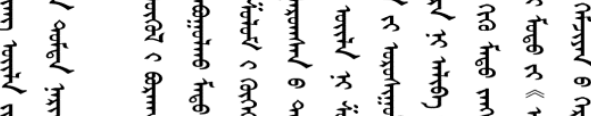

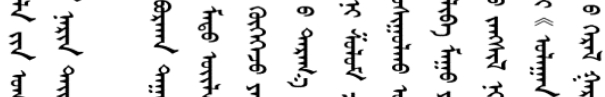

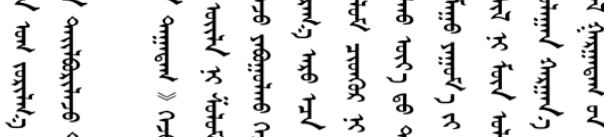

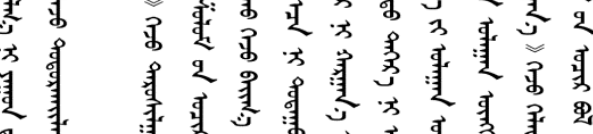

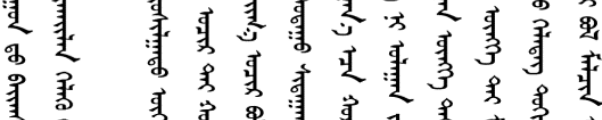

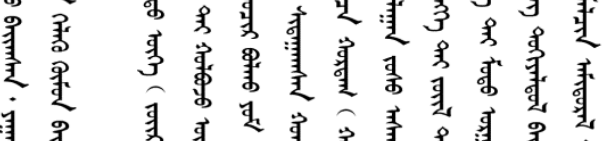

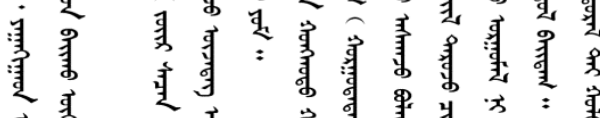

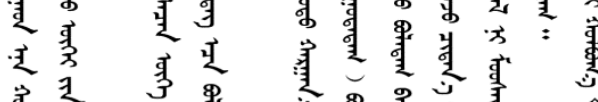

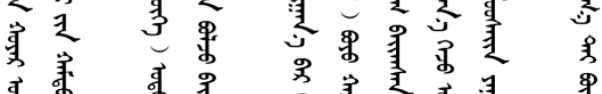

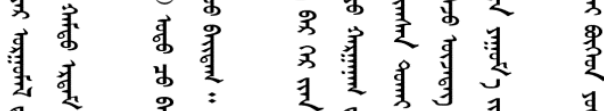

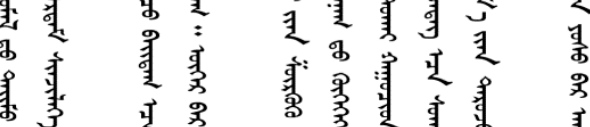

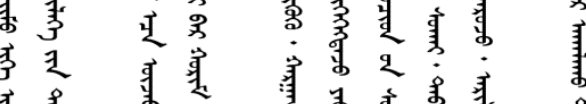

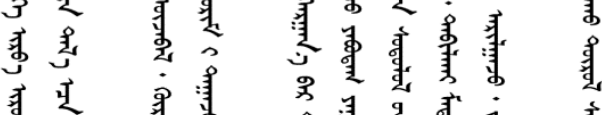

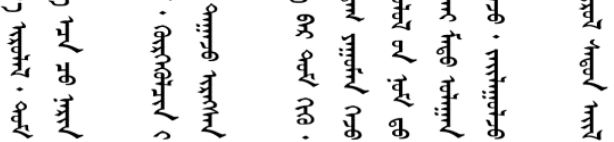




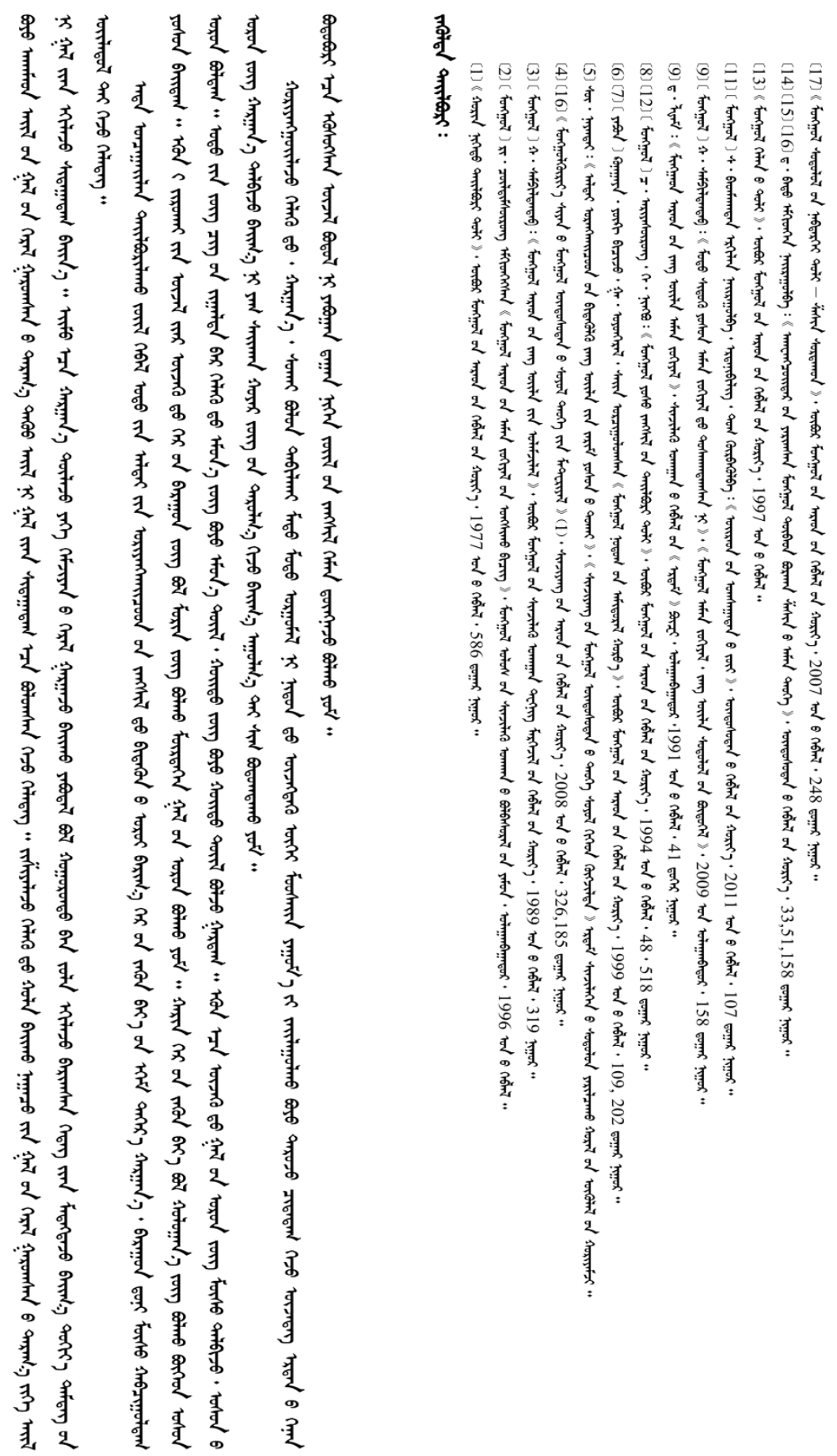





\title{
The Sino-Mongolian Glossary Dada yu/Beilu yiyu from the Ming Period and the Problem of its Dating $^{1}$
}

\author{
Pavel Rykin (Institute for Linguistic Studies, Russian Academy of Sciences, \\ Moscow)
}

\section{Introduction}

The glossary Dada yu/Beilu yiyu (further DDY / BLYY) belongs to a whole series of Sino-Mongolian vocabularies dating back to the late 16th or early 17 th centuries which are of considerable interest for Mongolic comparative studies as the only reliable sources for colloquial Mongolian of the Ming period (1368-1644). Several monuments of this kind are known today, ${ }^{2}$ but among them it is only the glossary from the Dengtan bijiu 登壇必究 by Wang Minghe 王鳴鶴 (1599) dealt with in the recently published monograph by Apatóczky (2009) that can be considered to be satisfactorily investigated. The other glossaries are at best available in hardly accessible editions published in China and Japan, mostly lacking any critical apparatus and containing a great number of errors, and at worst known only by their titles or some sample words scattered over the works of scholars who had the opportunity to work directly with their originals.

\footnotetext{
1 This paper was supported by the Russian Foundation for Humanities (project No. 15-04-00317a).

${ }^{2}$ For the lists of the most important Sino-Mongolian glossaries see e. g. Pelliot (1948, pp. 272-290), Rachewiltz (1977, pp. XII-XIV), Bousiyang (1984, pp. 193-197), Manduqu - Гarudi - Yuvan Čou (1997, pp. 43-45). The texts of some of these glossaries are published with transliterations, transcriptions, and notes by Manduqu (1995), but his publication leaves much to be desired.
} 
Until recently, the glossary under discussion has also remained almost completely uninvestigated and practically unknown to the scholarly world. Over the last few years, I have published several articles providing a general overview of the $D D Y / B L Y Y$ and addressing some aspects of its textual history and language system (Rykin 2007; 2012a-b), but as for its study, there is still much to be done. One of the most controversial issues is the dating of this Sino-Mongolian glossary, which is crucial for establishing the chronology of linguistic processes and phenomena reflected therein. It is noteworthy that for most of the other similar vocabularies preserved in Chinese works of the 16th and 17th centuries this issue cannot be raised at all, as they contain no or almost no indication of when they were written. As a rule, these vocabularies are dated to the years in which the whole Chinese works comprising them were published, although it is fairly clear that they could be taken from some earlier works which are no longer extant (see e. g. Apatóczky 2009, p. 6). Thus, according to a widespread opinion, expressed by Serruys, "the materials of the Ming vocabularies are certainly much older than the end of the Ming, but from what time they are in fact, cannot be established" (Serruys 1983, p. 167; cf. also Serruys 1982, p. 478). However, the DDY / BLYY holds an exceptional position among the contemporary glossaries of the same type in the sense that it does allow the actual date of its compilation to be established more or less exactly.

\section{Extant copies of the glossary and their features}

To begin with, general information about the contents and the main copies of the glossary is to be provided. The DDY/BLYY contains 710 entries grouped into subject categories (or headings, lei 類), with a special title for each: Tianwen 天文 “Celestial Bodies and Phenomena” (58 entries), Dili zashi deng 地理雜事等 “All Sorts of Terrestrial Things etc.” (527 entries), Renshi 人事 “Human Affairs” (84 entries), $W u$ 物 "Personal Items" (29 entries) and Zhi shu 支属 "Kind of Earthly Branches (Signs of Duodecimal Cycle)" (12 entries). Mongolian words of the glossary are phonetically rendered into Chinese characters using some special principles of transcription relating Mongolian and Chinese sounds to each other (Rykin 2012b). In each entry, the Chinese form is written by one or several (if the matter is a word combination) large characters, under which the equivalent Mongolian word or phrase transcribed by smaller characters is given. As regards the main copies of the $D D Y / B L Y Y$, two of them have come down to us:

(1) the manuscript copy acquired by the famous Russian Mongolist Alexei Pozdneev (1851-1920) in January 1893 during his journey into Mongolia and Chi$\mathrm{na}^{3}$ from a member of the Hanlin 翰林 Academy and subsequently published

\footnotetext{
${ }^{3}$ Apparently in Beijing, where he stayed from 21 December 1892 to 19 February 1893, having made only one short trip outside the Chinese capital (see Pozdneev 1898, p. IX). Unfortunately, this period
} 


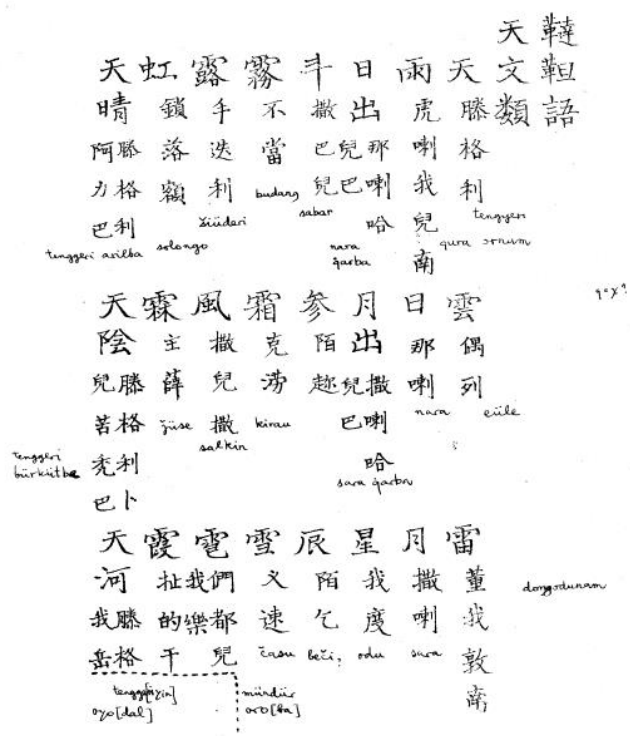

Figure 1: The first page of Pozdneev's publication of the $D D Y / B L Y Y$

by him in the third volume of his Lectures on the History of Mongolian Literature (Pozdneev 1908, pp. 8-39) (further P). The textual history and the present whereabouts of the original copy are unknown. In P, the glossary is entitled Dada yu 靯羍 靼語, lit. “Tatar Words”, and divided into 705 entries (cf. Fig. 1);

(2) the copy, or rather the group of closely related copies, incorporated in the $W u$ bei zhi 武備志 “Notes about Military Preparations” (1621, presented to the Emperor in 1628) by Mao Yuanyi 茅元儀 (1594-ca. 1641), ${ }^{4}$ the voluminous (240 juan 卷) work on military affairs and relations of China with neighbouring peoples (further W). This work has been handed down in two recensions: the original one, printed in the Tianqi 天啓 period, and the "corrected" one, appeared probably only after 1644 when a number of characters objectionable to the Manchu dynasty, as well as the whole section on the Jurchen in juan 228, were omitted by the Qing censors (Franke 1968, p. 209). The text of the glossary is available in both recensions, forming the latter part (ff. 15a-29a) of juan 227.5 In these copies, the glossa-

is not reflected in Pozdneev's diaries containing detailed information about his journey (Pozdneev 1896-1898).

${ }^{4}$ For him see DMB II 1053a-1054b.

5 The $W u$ bei zhi is used by us in two facsimile editions of the Xuxiu siku quanshu 續修四庫全書 (Shanghai, 1995-2002: ce 册 963-966, Zibu 子部, Bingjia lei 兵家類; our glossary is in ce 966, pp. 213220) and the Siku jinbui shu congkean 四庫禁炇書叢刊 (Beijing, 2000: Zibu, ce 23-26; our glossary is in ce 26, pp. 549-556). The copy from the Xuxin siku quanshu belongs to the first, original recension, while that from the Siku jinhui shu congkan derives from the later, "corrected" one. In addition, I have 
ry bears the name Beilu yiyu 北虜譯語, lit. “Translated Words of Northern Barbarians", and consists of 689 entries (cf. Fig. 2).

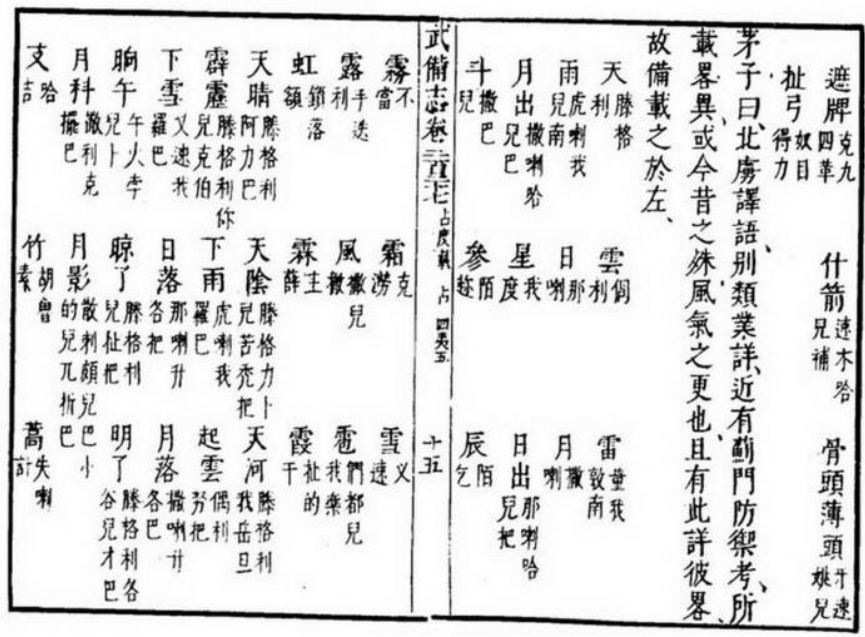

Figure 2: The first page of the $D D Y / B L Y Y$ from the 1995-2002 facsimile edition of the $W u$ bei $z h i$

There is a curious misunderstanding related to the textual history of W. As has been repeatedly noted by the specialists in Ming literary sources, juan 223-229 of the $W u$ bei zhi allegedly reproduce the collection of writings by the Ming author Ye Xianggao 葉向高 (1559-1627) ${ }^{6}$ called Si yi kao 四夷考 “A Study on the Barbarians of the Four [Cardinal Points]" (1606) dealing with history and historical geography of Mongolia, Japan, Korea, and East Turkestan (Franke 1968, pp. 205-206; Hambis 1969, pp. lxxviii-lxxix). Therefore, the glossary Beilu yiyu should have originally been an integral part of this collection as well. Being unable to properly check this view I have uncritically adopted it in some of my earlier papers (Rykin 2012a, p. 87; 2012b, p. 324), but now when I have gained access to the 1991 facsimile edition of the Si yi kao (SYK) it seems evident that no significant similarities between the $W u$ bei zhi and the work by Ye Xianggao can be revealed, in particular regarding the glossary at issue which is totally missing in the latter. The reason for this error, deeply rooted in the literature, is hard to explain, but an assumption can be made that it may have been due to partial identity of the title Si yi kao and the section title Si yi 四夷, lit. "Barbarians of the Four [Cardinal Points]”, assigned by Mao Yuanyi

drawn on a microfilm of the $W u$ bei zhi which is held in the library of Peter the Great Museum of Anthropology and Ethnography, Russian Academy of Sciences (call number m/f 36), as well as on a later manuscript copy of the glossary kept in the Oriental Collection, Klebelsberg Library, University of Szeged (Hungary), apparently made from a xylographic edition of the $W u$ bei zhi by order of the famous Hungarian orientalist Lajos Ligeti (1902-1987) or even by himself.

${ }^{6}$ For him see DMB II 1567a-1570b. 
to juan 223-239 of his military encyclopaedia, where China's foreign relations with neighbouring countries and peoples are described.

The collation of both copies of the glossary reveals more than 300 variant readings, but it is only 141 that may be viewed as significant, while the rest of them concern mainly allographic variation of characters (semantic or transcriptional) and the use of homophonic characters in the same Mongolian words. In 73 cases, the correct or most reliable readings are given by $\mathrm{P}$, in 68 cases - by W. The difference appears to be insignificant in quantitative terms, but the errors and omissions contained in W should be considered much more serious and grave; for instance, it lacks all the sectional titles which occur in $\mathrm{P}$ and must have been present in the original text, as has been demonstrated by other Sino-Mongolian glossaries, as well as the whole final section containing twelve Earthly Branch names (entries Nos. 699-710). W bears the discernible traces of literary and calligraphic elaboration which is especially conspicuous in the replacement of simplified forms of certain characters, observed in $\mathrm{P}$, with the corresponding traditional characters, the inconsistency of which suggesting that the simplified forms are to be considered older. The very name Dada yu found in Pozdneev's copy seems to have been part of the original text as well. For these reasons, P may be viewed as the best and earliest copy of the glossary, closer to the lost original, whereas W, on the contrary, looks like a later and somewhat emended version. However, the fact that W contains five entries (Nos. 395, 397, 630, 633, 684) which are missing in P, as well as an extensive group of more reliable readings than those preserved in the latter, enables us to regard both copies as separate, independently deriving from a nonextant original.

\section{Date of composition}

To return to our topic, nowadays there exist three hypotheses on the dating of the original text of the DDY/BLYY:

(1) The eminent French sinologist and orientalist Paul Pelliot (1878-1945), who was the first European scholar to systematically use the language material of our glossary in his works, considered it to be compiled ca. 1600 within the limits of Manchuria or Eastern Mongolia (Pelliot 1925, p. 199; 1927, p. 283; 1948, p. 288);

(2) The Polish Altaicist Marian Lewicki (1908-1955) held that the glossary might have been of a more recent origin going back to the Manchu period (16441911) (Lewicki 1949, p. 7);

(3) According to Henry Serruys (1911-1983), the foremost authority on SinoMongol relations during the Ming, the material of the DDY/BLYY (he meant specifically W) may well date from the Mongol period or from the early Ming (Serruys 1983 , p. 167).

While the differences between these hypotheses are quite large, none of them is based on solid argumentation, which makes it difficult to establish what kinds of 
evidence they are derived from. The second hypothesis, proposed by Lewicki, should be at once regarded as invalid and excluded from our discussion, as it does not take into account the actual time of the $W u$ bei $2 h i$ s compilation. As its partial justification it can be suggested that Lewicki has apparently relied upon P alone, without even being aware of its relation to firmly datable W. As far as two other hypotheses are concerned, their proper evaluation requires a thorough analysis of all the information contained in the glossary which could be used for its dating. In this presentation, I will try to provide my own solution to the problem by examining the chronology of Sino-Mongolian place names attested in the DDY / BLYY.

A unique feature of the glossary, which distinguishes it from other vocabularies of the same kind, is that it contains 69 geographical names referring to the northern part of modern Hebei 河北 and Shanxi 山西 Provinces, as well as the areas of Beijing Municipality 北京市, with their Mongolian counterparts. Such a large number of toponyms is not found in any other monument of Middle Mongol, Preclassical Written Mongol or early Classical Written Mongol before the rise of Mongolian cartography in the early 18th century. ${ }^{7}$ The Chinese place names as occurring in the DDY / BLYY are well known from various historico-geographical works compiled in the late Ming or early Qing dynasties, hence their main characteristics like the time of appearance and subsequent changes due to some historical events can be established without much difficulty. Since the section on toponyms is present in both copies of the glossary, there is no reason to doubt that it was an integral part of the original text as well, therefore we can use the conclusions to be drawn from a chronological investigation of the geographical names to suggest the possible date for the composition of the lost original as a whole.

\subsection{Terminus post quem}

The lower limit of a possible dating to be suggested for the DDY/BLYY is the most controversial due to the widespread tendency to take Sino-Mongolian glossaries of the late Ming period to be much older than they actually are. In this respect, it is significant that a large number of Chinese place names attested in the glossary refer to the towns or forts which were built in the early or mid-16th century. Chronologically, the most recent among them are the following:

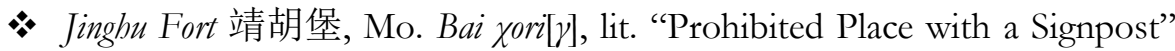
(No. 340), the former Baihepu Village 白河堡村 in the northeastern part of modern Yanqing County 延庆县 of Beijing, now in the area covered by Baihepu Reservoir 白河堡水库 $\left(40^{\circ} 38^{\prime} 44.72^{\prime \prime} \mathrm{N}, 116^{\circ} 10^{\prime} 4.63^{\prime \prime} \mathrm{E}\right)$. According to different data, it was built in the 29th (1550) or 35th (1556) year of the Jiajing 嘉靖 Period. In the first year of the Longqing 隆慶 Period

\footnotetext{
${ }^{7}$ On the Mongolian carthographic tradition of the $18^{\text {th }}-$ early $20^{\text {th }}$ century see, for instance, the classical works by Heissig (1944) and Haltod (1966).
} 
(1567), its earthen walls were faced with brick. It belonged to the Eastern Circuit (Dong lu 東路) within the military district of Xuanfu (Xuanfu z̧hen 宣府鎮), being a strategically important point in the defense system on the northern borders of the Ming empire (JBTS 66b; DMHD CXXVI 17b; XDSTS I 86a-b; DSFYJY XVII 782; MS XL 901; XHFZ VIII 27a).

* Chadao Town 岔道城, Mo. *Su: 8 bayan xoto, lit. "Prosperous Town in a [Mountain] Valley [?]” (No.336), the modern Chadao Village 岔道村 $\left(40^{\circ} 21^{\prime} 48.35^{\prime \prime} \mathrm{N}, 115^{\circ} 59^{\prime} 22.80^{\prime \prime} \mathrm{E}\right)$ in the southern part of Yanqing County, situated around $2 \mathrm{~km}$ to the northwest of the Badaling 八达岭 Pass. It was built in the 30th year of Jiajing (1551), its walls were strenghthened and faced with brick in the 5th year of Longqing (1571). In the Ming Dynasty, it originally belonged to the Eastern Circuit of the military district of Xuanfu, but after the organization of the circuit called the Southern Mountains (Nan shan lu 南山路) in the 45th year of Jiajing (1566), it became part of the latter (JBTS 66b; DMHD CXXVI 18b; XDSTS I 103a-b; DSFYJY XVII 780-781; XHFZ VIII 26b).

* Wayaokon 瓦窑口, Mo. Boro moritu, lit. "Where There Is a Grey Horse" (No. 348), the present-day Wayaokou Village 瓦窑口村 (40³2'55.50"N, $\left.114^{\circ} 07^{\prime} 13.10^{\prime \prime} \mathrm{E}\right)$ in the northern part of Tianzhen County 天镇县, Shanxi Province. During the Ming, it was a fort built in the 37 th year of Jiajing (1558), its walls being faced with brick in the 6th year of Longqing (1572). It belonged to the Eastern Circuit (Dong lu 東路) within the military district of Datong (Datong zhen 同鎮) (JBTS 76b; DMHD CXXVI 21a; XDSTS II 36a-b; SYCZK III 19a; DSFYJY XLIV 2026).

* Yongjia Fort 永家堡, Mo. Xubxai caija, lit. "Bare (or: Withered) Fort" (No. 349), the modern Yongjiapu Village 永嘉堡村 $\left(40^{\circ} 31^{\prime} 28.75^{\prime \prime N}\right.$, $\left.114^{\circ} 15^{\prime} 31.95^{\prime \prime E}\right)$ in the northeastern part of Tianzhen County, Shanxi Province. It was built in the 37th year of Jiajing (1558), its walls were provided with brick parapets in the 2nd year of the Wanli 萬曆 Period (1574), and later, in the 19th year of Wanli (1591), completely faced with brick. It also belonged to the Eastern Circuit of the Datong military district (JBTS 76b; XDSTS II 37a-b; SYCZK III 18b-19a; DSFYJY XLIV 2026).

It is clear that the original text of the DDY / BLYY could not have been compiled before the strongholds listed therein were constructed, i. e. before 1558, the year when two the most recent of them, Wayaokou and Yongjia Fort, were built. However, even this date is not the latest one. The glossary lists the name of Yanqingzhou 延慶州, Mo. Kökö laustu, lit. “Where There Is a Grey Mule” (No. 337), the modern

${ }^{8}$ An asterisk (*) is used to mark a hypothetically reconstructed form. 
Yanqing Town 延庆镇 $\left(40^{\circ} 27^{\prime} 48.58^{\prime \prime} \mathrm{N}, 115^{\circ} 58^{\prime} 45.56 " \mathrm{E}\right)$ of the municipality of Beijing, northwest of the city proper of Beijing; during the Ming it referred to the seat of the Subprefecture (zhou 州) of Yanqing 延慶, as a civil administration unit directly attached to the Metropolitan Area (Jingshi 京師, or Northern Zbili 北直隸), and as a tactical hierarchy unit (on this term, see Hucker 1958, pp. 62-63) belonging to the Eastern Circuit of the Xuanfu military district. The Subprefecture itself and its seat were originally called Longqingzhou 隆慶州, while the name indicated in the DDY / BLYY was given to them as late as the 1st year of Longqing (1567) due to the fact that the character long 隆 was selected for Emperor's era name and thereby became taboo (HMJBK IV 2b; XFZZ XI 8a-9b; XDSTS I 88a-b; DSFYJY XVII 777-778; MS XL 901; XHFZ VIII 25a-26a). It is worth noting that Longqingzhou is referred to as such on the maps of the Xuanfu district as contained in the Huang Ming jiu bian kao 皇明九邊考 (1541) (HMCBK IV i) and the Xuanfu zhen $z h i$ 宣府鎮志 (1561) (XFZZ xv, xvii), whereas the new name Yanqingzhou is already indicated on the map of the same district from the Jiu bian tu shuo 九邊圖說 (1569) (JBTS 65b, 66b).

Therefore, the original text of the DDY / BLYY must have been written after 1567, when the last firmly datable event took place, i. e. the renaming of Longqingzhou to Yanqingzhou.

\subsection{Terminus ante quem}

In fact, there is an important cue to set the upper limit of the glossary's dating, which consists in that its text could definitely not appear after the completion of the $W u$ bei $z h i$ (1621). The study of Sino-Mongolian place names as attested in the $D D Y / B L Y Y$ in their relation to the civil and military administrative system of the Ming allows us to push this limit almost twenty years farther into the past.

Under the Ming, the central government exercised control over the entire territory of China, except for two Metropolitan Areas (Jingshi 京師) around the old (Nanjing 南京) and new (Beijing 北京) capitals of the empire, using two overlapping models of administrative territorial division, a civil one and a military one. The basic units of the civil model were Provinces (sheng 省), which were further divided into Prefectures (fu 府), Subprefectures (zhou 州) and Counties (xian 縣). Within the military model, local administration was exercised by five Chief Military Commissions ( $W u$ jun $d u d u f u$ 五軍都督府), which were responsible for supervising Regional Military Commissions ( $d u$ z $b i b u i$ shi si 都指揮使司, or simply dusi 都 司) or Branch Regional Military Commissions (xing du zhibui shi si 行都指揮使司, abbreviated to xing dusi 行都司), and these in turn were in charge of Commanderies or Guards (wei 衛), Chiliarchies or Battalions (qianhu suo 千户所) and Centuries or Companies (baibu suo 百户所). In addition, along the northern frontiers of Chi- 
na, the most vulnerable to outside invasions, a third model was introduced, that of tactical hierarchy, which consisted of Military Districts (zhen 鎮) or Border Areas (bian 邊), divided into Circuits ( $l u$ 路) (for more details, see Hucker 1958, pp. 5, 78, 44-45, 57-59, 63; 1998, pp. 12-15, 55, 75, 88-90, 99-100; cf. Serruys 1955, pp. 2, 9-16; 1959, pp. 253-254).

Among the geographical names listed by the DDY/BLYY, there are units of both civil and military models, but they are not decisive. It is the tactical hierarchy that is of key importance as a factor determining the order of appearance of all the place names in the text. The list starts off with Beijing, the capital of the empire (No. 300), followed by the names for strongholds belonging to the military district of Xuanfu (Nos.301-341), and lastly, the names for those belonging to the Datong military district (Nos.342-368). Moreover, within each subsection corresponding to a military district, the items are arranged mostly according to the Circuits they belong to, although there are some rare exceptions (in fact, only three are to be firmly identified ${ }^{9}$ ), which can be imputed either to the inadvertence of the author, or to copyists' errors apparently inherited from a common ancestral version of $\mathrm{P}$ and $\mathrm{W}$. Be that as it may, there is a clear dependence between the position of a place name in the list and its relation to a Circuit within the Xuanfu or Datong district. In this respect, the following two names from the list are the most useful for our purposes: ${ }^{10}$

* Longmen Town 龍門城, Mo. Boro xoto, lit. “Grey Town” (No. 306), the present-day Longguan Town 龙关镇 (4046'51.27"N, 115³4'20.24"E) in the southwestern part of Chicheng County 赤城县, Hebei Province. The $D a$ Ming huidian 大明會典 (1587) and the earlier historico-geographical works put it under the jurisdiction of the Northern Circuit (Bei lu 北路) within the military district of Xuanfu (HMJBK IV 2b; XFZZ XI 11b-12a; JBTS 68a; DMHD CXXVI 17b), whereas on the maps of the Xuan Da Shanxi sanæhen tushuo 宣大山西三鎮圖說 (1603) it is shown as located in the Cen-

\footnotetext{
${ }^{9}$ (1) The city of Datong 大同城 (No. 342), the administrative center of the military district of the same name, is followed by Tiancheng 天城 (No. 343) and Yanghe 陽和 (No. 344), respectively the new (from 1565) and the old seat of the Eastern Circuit, but the other names of this Circuit's strongholds are listed in entries Nos. 348-355, whereas three preceding entries (Nos. 345-347) contain the place names of the Xinping Curcuit (Xinping l $u$ 新平路); (2) The Left Commandery of Wanquan 萬 全左衛 (No. 328), belonging to the Upper Western Circuit (Shang xi lu 上西路) of the Xuanfu military district, is separated from the other geographical names of the same district (entries Nos. 317320) by a list of towns and forts of the Lower Western Circuit (Xia xi lu 下西路); (3) Among the strongholds of the Eastern Circuit within the Xuanfu district, we find Chadao Town (see above) which in fact belongs to the Circuit of the Southern Mountains, although it was also part of the Eastern Circuit until 1566.

${ }^{10}$ It should be stressed that only those place names have been selected that could be identified without any doubt. Some items whose position in the list seems to be ambiguous have been excluded from consideration here.
} 
tral Circuit (Zhong lu 中路) (XDSTS I 76a-b). In the DDY/BLYY, it is listed among the fortified places of the Northern Circuit.

* Yu₹bou 蔚州, Mo. U: li suburzatu, lit. "Where There Is an Owl Pagoda" (No.332), the modern Yuzhou Town 蔚州镇 $\left(39^{\circ} 50^{\prime} 22.69^{\prime \prime} \mathrm{N}\right.$, $\left.114^{\circ} 33^{\prime} 59.16^{\prime \prime} \mathrm{E}\right)$, the seat of Yu County 蔚县 in northwestern Hebei. In the Da Ming buidian and the earlier sources, it is referred to as belonging in the Southern Circuit (Nan lu 南路) of the Xuanfu district (HMJBK IV 2b, 4b; XFZZ XI 20a-22b; JBTS 71a; DMHD CXXVI 18a), but the Xuan Da Shanxi san₹hen tushuo locates it within the Datong military district as directly subordinate to the Datong General Surveillance Circuit (Datong xun dao 大 同巡道) (XDSTS I 34a-b, II 14a-b; cf. also SYCZK III 34a-b). In the $D D Y / B L Y Y$, it is found at the end of the list comprising the names of the strongholds located in the Southern Circuit of the Xuanfu district.

Unfortunately, we do not know precisely when administrative reassignment of both towns within the tactical hierarchy occurred, so it is only possible to state that this event took place in the period between 1587 and 1603. It would be tempting to regard it as related to administrative territorial reorganization of the Xuanfu military district, carried out in the 18th year of Wanli (1590) and resulted in the division of the Northern Circuit into an Upper Northern Curcuit (Shang bei lu 上北 路) and a Lower Northern Circuit (Xia bei lu 下北路) (XDSTS I 57a; cf. Serruys 1959, p. 254), all the more so that Longmen, the first of the above mentioned strongholds, originally belonged to the Northern Circuit as well. However reasonable it may seem, this assumption is based on circumstantial evidence alone and needs to be further validated. So far, what is absolutely clear is that the original version of the DDY / BLYY could not have been compiled after 1603, the year when the Xuan Da Shanxi sanz̧en tushuo was published, in which the new administrative territorial status of Longmen and Yuzhou is already indicated.

At first glance, some further guidance as to the dating of the glossary seems to have been provided by two Mongolian place names, remarkable for their forms, namely Bur ${ }^{11}$ xoto, lit. “Clay Town”, referring to Geyu Fort 葛峪堡 (No. 310), the modern Geyupu Village 葛峪堡村 $\left(40^{\circ} 44^{\prime} 39.38^{\prime \prime N}, 115^{\circ} 11^{\prime} 3.64^{\prime \prime E}\right)$ in the northeastern part of Xuanhua County 宣化县, Hebei Province, and Siro: Xoto, lit.

\footnotetext{
${ }^{11}$ For bur (bu: $r$ ?), cf. WMo buur bur 'argile' (Kow. II 1158a), 'muddy; obscure, dark, shady' (L 137a), Kh po: $r$ 'pottery clay' (BAMRS I 295a), Bur bor 'silt', 'clay (for pottery)', 'friable, loose' (BRS 113a), BurM bor 'swamp, marsh', 'clay' (BAT 114b). On this word as a part of various place names, see e. g. Murzaev (1996, p. 215). Cf. also the name buur ayula, lit. "Clay Mountain", on the Mongolian maps from the late 19th and early 20th centuries (Haltod 1966, p. 36a, No. 2398). Mo. bur $\leftarrow$ Turkic; cf. Turkic bor $\sim$ bur < CT *bo: $r$ 'chalk', 'clay' (VEWT 80b; ĖSTJa 1978, pp. 192-193; SIGTJa 1997, pp. 375-376).
} 
“Earthen Town”, standing for the Right Commandery of Datong 大同右衛12 (No. 363), of course not the whole of its territory, but only the commandery seat. These names have undoubtedly gone back to the period when both strongholds had earthen walls, like almost all of the towns and forts along China's northern frontiers until the last third of the 16th century. Meanwhile, it is known that the seat of the Datong Right Commandery was strengthened with brick-faced walls in the 3rd year of Wanli (1575) (XDSTS II 66b; SYCZK III 48a), and three years later, in 1578, the same was done for Geyu Fort as well (XDSTS I 68b). Accordingly, the original text of the glossary should have been regarded as dating to before 1575 , so the possible timeframe of its composition would have been narrowed to less than a decade, 1567 to 1575 ! However, it would be unreasonable to consider this narrow dating to be reliable enough, as geographical names, especially those in common usage, often remain unchanged long after loss of specific conditions which gave rise to their appearance. For instance, in the report by Ivan Petlin, a Siberian Cossack, the head of the first Russian official mission to China in 16181619, where a number of Chinese towns located along the northern frontiers of the Ming empire are mentioned by their Mongolian names in nearly the same form as they have in our glossary, ${ }^{13}$ the name Siro Gorod "Earthen Town" is found, which seems to be a partial calque from Mo. Siro: $\chi$ oto, apparently referring to the seat of the Datong Right Commandery as well (cf. Serruys 1983, pp. 168-169). ${ }^{14} \mathrm{It}$ is described as a "stone town, high and big" (gorod kamennoj, vysok $i$ velik) (Demi-

\footnotetext{
12 According to different data, it was established on the day dingsi 丁巳 of the first month of the 3rd year of Hongwu 洪武 (3 March 1370) (TZSL XLVIII 7a) or in the eighth month of the 25th year of the same era (27 August-24 September 1392) (MS XLI 971) under the jurisdiction of the Shanxi Branch Regional Military Commission (Shanxi xing du zhibui shi si 山西行都指揮使司). The commandery seat was originally located in Datong, but in the 7th year of the Yongle 永樂 Period (25 January 1409-12 February 1410) it was shifted to the former seat of the Dingbian 定邊 Commandery, presently the administrative center of Youyu County 右玉县 $\left(39^{\circ} 59^{\prime} 14.12^{\prime \prime} \mathrm{N}, 112^{\circ} 27^{\prime} 35.76 " \mathrm{E}\right.$ ) in northwestern Shanxi, which at the same time served as the seat of the Central Circuit (Zhong $l u$ 中路) within the military district of Datong (HMJBK V 1a, 4a; JBTS 80a; DMHD CXXVI 21b; SDSTS II 64a, 66a-b; SYCZK III 48a-b; DSFYJY XLIV 2020; cf. also ZLDDC 55a; Niu Pinghan 1997, pp. 392, 395).

13 Among the members of Petlin's mission there were two Mongolian lamas, named Tarkhan-laba and Bilikta-laba, who were sent by the Altan-qan Šoloi Ubaši Qong Tayiji (?-1623) and served as guides and interpreters for the Russian delegation (RMO 80, 95; cf. Demidova, Mjasnikov 1966, pp. 23-24). It is due to them that Chinese place names and administrative terms referred to in Petlin's report are attested in the form characteristic of the colloquial Mongolian pronunciation used in the early 17 th century.

${ }^{14}$ The identification of Petlin's Siro Gorod with the town of Xuanfu, the modern Xuanhua District 宣 化区 in Zhanjiakou prefecture-level city 张家口市, Hebei Province, proposed by Demidova and Mjasnikov (1966, p. 60, note 18), appears to be incorrect, as Xuanfu is called Bayan sümü xoto, lit. "Town of a Prosperous Temple", in the DDY / BLYY (No. 301) and other sources from the Ming and Qing periods. See Serruys (1983). According to Pozdneev (1898, p. 19), the name Bain-süme as applied to Xuanhua was still in use in the late 19th century.
} 
dova, Mjasnikov 1966, p. 48a; cf. RMO 83). Thus, more than forty years after the city walls were faced with brick, it was still called by its old name "Earthen Town" (Petlin's Siro Gorod), long since grown obsolete.

\section{Conclusion}

To sum up, the original text of the DDY/BLYY (and therefore the Mongolian language material contained therein) is to be firmly dated to the period between 1567 and 1603, or even between 1567 and 1590, if we take into account circumstantial evidence relating to reorganization of the Xuanfu military district. Hence, it seems clear that the dating suggested by Pelliot is essentially correct, whereas Serruys' view on this issue should be rejected for lack of proof. It follows that the glossary's original version was surely not contemporaneous with $\mathrm{W}$, the earliest known printed edition of the monument, but at the same time it is likely to have not been separated from the latter by a considerable period of time. In my opinion, similar conclusions may well also be valid for the other Sino-Mongolian vocabularies from the end of the Ming, although to establish the actual dates of their composition is much more difficult, if at all possible.

\section{Abbreviations}

BAMRS — Bol'shoj akademičeskij mongol'sko-russkij slovar', ed. G. C. Pjurbeev. T. 1-4. 2001-2002, Academia.

BAT - Gantogtox, G.: Buriad ajalguuny tol' [Dictionary of the Buryat Dialect]. 2010 (2011), Bèmbi san.

BRS — Čeremisov, K. M.: Burjatsko-russkij slovar'. 44000 slov. 1973, Sovetskaja ènciklopedija.

Bur - Buryat.

BurM — Buryat dialects of Mongolia.

CT - Common Turkic.

DDY /BLYY — the Sino-Mongolian glossary Dada yu 韃靼語/Beilu yiju 北虜譯 語 $(\mathrm{P} ; \mathrm{W})$.

DMB — Dictionary of Ming Biography, 1368-1644, ed. L. Goodrich, Fang Chaoying. Vol. 1-2. 1976, Columbia University Press.

DMHD — Shen Shixing 申時行; Zhao Yongxian 趙用賢 et al. 等: Da Ming huidian 大明會典 [Collected Regulations of the Great Ming]. Vol. 1-4. In: Xuxiu Siku quanshu 續修四庫全書 [Enlarged and Revised Complete Library 
in Four Sections]. Vol. 789-792. Shibu 史部 [Histories]; Zhengshu lei 政書類 [Political Books]. 1995-2002, Shanghai guji chubanshe 上海古籍出版社.

DSFYJY — Gu Zuyu 顧祖禹: Dushi fangyu jiyao 讀史方輿紀要 [Essentials of Geography for Reading History]. 2005, Zhonghua shuju 中華書局. (Zhongguo gudai dili zongzhi congkan 中國古代地理總志叢刊.)

ESTJa 1978 - Sevortjan, Ė. V.: Ėtimologičeskij slovar’ tjurkskix jazykov. Obščetjurkskie i mežtjurkskie osnovy na bukvu “B”. 1978, Nauka.

HMJBK - Wei Huan 魏煥: Huang Ming jiu bian kao 皇明九邊考. Ming Jiajing keben yingyin 明嘉靖刻本影印 [Study of the Nine Border Areas of the Ming Dynasty. A Facsimile Edition of the Ming Xylograph from the Jiajing [Period] (7 February 1522-18 February 1567]). In: Wei Huan 魏煥: Huang Ming jiu bian kao 皇明九邊考. Ming Jiajing keben yingyin 明嘉靖刻本影印 [Study of the Nine Border Areas of the Ming Dynasty. A Facsimile Edition of the Ming Xylograph from the Jiajing [Period] (7 February 1522-18 February 1567]). Zheng Xiao 鄭曉: Huang Ming si yi kao 皇明四夷考. Ming Wanli kanben yingyin 明萬曆利本影印 [Study on the Barbarians of the Four [Cardinal Points] during the Ming Dynasty. A Facsimile Edition of the Ming Xylograph from the Wanli [Period] (12 February 1573-3 February 1620)]. 1968-1969, Taiwan huawen shuju 台灣華文書局, 1-456. (Zhonghua wenshi congshu 中 華文史叢書 15-16.)

JBTS — [Huo Ji 霍冀: ] Jiu bian tu shuo 九邊圖說. Ming Longqing san nian kanben 明隆慶三年刊本 [Maps and Descriptions of the Nine Border Areas. A Ming Xylograph from the 3rd Year of Longqing (27 January 1569-14 February 1570)]. In: [Huo Ji 霍冀:] Jiu bian tu shuo 九邊圖說. Ming Longqing san nian kanben 明隆慶三年刊本 [Maps and Descriptions of the Nine Border Areas. A Ming Xylograph from the 3rd Year of Longqing (27 January 1569-14 February 1570)]. Feng Yuan 馮瑗: Kaiyuan tu shuo 開原圖說. Ming Wanli kanben 明萬曆刊本 [Maps and Descriptions of Kaiyuan. A Ming Xylograph from the Wanli [Period] (12 February 1573-3 February 1620)]. 1981, Guoli zhongyang tushuguan 國立中央圖書館, 001-316. (Xuanlangtang congshu 玄覽堂叢書 5.)

Kh - Khalkha.

Kow. - Kowalewski, J. E.: Dictionnaire mongol-russe-français. T. 1-3. 18441849, Imprimerie de l'Université.

L — Mongolian-English Dictionary, ed. F. D. Lessing. 1960, University of California Press. 
Mo - Mongolic.

MS — Zhang Tingyu 张廷玉 et al. 等: Ming shi 明史 [History of Ming]. Vol. 128. 1974, Zhonghua shuju 中華書局.

P — the manuscript copy of the DDY/BLYY published by A. M. Pozdneev (Pozdneev 1908, pp. 8-39).

RMO -Russko-mongol'skie otnošenija, 1607-1636. Sbornik dokumentov, ed. L. M. Gataullina, M. I. Golman, G. I. Slesarčuk. 1959, Izdatel'stvo vostočnoj literatury. (Materialy po istorii russko-mongol'skix otnošenij.)

SDSTS — Yang Shining 楊時寧: Xuan Da Shanxi sanzhen tushuo 宣大山西三鎮 圖說. Ming Wanli guimao kanben 明萬曆癸卯刊本 [Maps and Descriptions of the Military Districts of Xuan[fu], Da[tong], and Shanxi. A Ming Xylograph from the [Year] Guimao of Wanli (11 February 1603-30 January 1604)]. 1981, Guoli zhongyang tushuguan 國立中央圖書館. (Xuanlangtang congshu 玄覽 堂叢書 4.)

SIGTJa 1997 — Sravnitel'no-istoričeskaja grammatika tjurkskix jazykov. Leksika, ed. Ė. R. Tenišev. 1997, Nauka.

SYCZK - Wang Shiqi 王士琦: Sanyun chouzu kao 三雲籌沮考. Ming Wanli keben 明萬曆刻本 [Study on Miscellanies of Sanyun. A Ming Xylograph from the Wanli [Period] (12 February 1573-3 February 1620)]. 1972, Guangwen shuju 廣文書局. (Guoli Beiping tushuguan shanben congshu 國立北平圖書 館善本㵵書 1. Shiliao wu bian 史料五編 4.)

SYK - Ye Xianggao 葉向高: Si yi kao 四夷考 [A Study on the Barbarians of the Four [Cardinal Points]]. 1991, Zhonghua shuju 中華書局. (Cong shu ji cheng chu bian 叢書集成初編 3276.)

TZSL - Ming shilu 明實錄. Ming Taizu shilu 明太祖實錄 [Veritable Records of the Ming. Veritable Records of Ming Taizu]. 1961-1966, Zhongyang yanjiuyuan lishi yuyan yanjiusuo 中央研究院歷史語言研究所.

VEWT - Räsänen, M.: Versuch eines etymologischen Wörterbuchs der Türksprachen. 1969, Suomalais-Ugrilainen Seura. (Lexica Societatis FennoUgricae 17:1.)

W - the copy (copies) of the DDY/BLYY incorporated in the $W u$ bei zhi 武備志 “Notes about Military Preparations" (1621) by Mao Yuanyi 茅元儀 (Mao Yuanyi 1995-2002, vol. 966, p. 213-220; 2000, vol. 26, p. 549-556).

WMo - Written Mongol. 
XFZZ — Sun Shifang 孫世芳; Luan Shangyue 欒尚約: Xuanfu zhen zhi 宣府鎮 志. Ming Jiajing sishi nian kanben yingyin 明嘉靖四十年刊本影印 [Gazetteer of the Military District of Xuanfu. A Facsimile Edition of the Ming Xylograph from the 40th Year of Jiajing (26 January 1561-13 February 1562]. 1970, Chengwen chubanshe 成文出版社. (Zhongguo fangzhi congshu 中國方志叢 書. Saibei difang 塞北地方 19.)

XHFZ - Wu Tinghua 吳廷華; Wang Zhefu 王者輔 et al. 等: Xuanhua fu zhi 宣 化府志. Qing Qianlong ba nian xiu ershier nian dingbu chong kanben yingyin 清乾隆八年修二十二年訂補重刊本影印 [Gazetteer of Xuanhua Prefecture. A Facsimile Edition of the Qing Xylograph Produced in the 8th Year of Qianlong (26 January 1743-12 February 1744), Revised and Enlatged in the 22nd Year [of the Same Period] (18 February 1757-7 February 1758)]. 1968, Chengwen chubanshe 成文出版社. (Zhongguo fangzhi congshu 中國方志叢 書. Saibei difang 塞北地方 18.)

ZLDDC — Zhongguo lishi diming da cidian 中国历史地名大辞典 [Large Dictionary of Chinese Historical Place Names], ed. Wei Songshan 魏嵩山. 1995, Guangdong jiaoyu chubanshe 广东教育出版社.

\section{References}

Apatóczky, Á. B. 2009, Yiyu 譯語 (Beilu yiyu 北虜譯語). An Indexed Critical Edition of a Sixteenth-century Sino-Mongolian Glossary. Global Oriental. (Languages of Asia 5.)

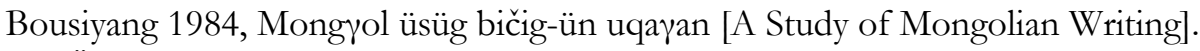

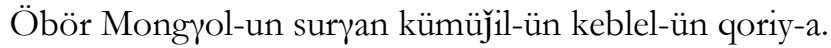

Demidova, N. F.; Mjasnikov, V. S. 1966, Pervye russkie diplomaty v Kitae («Rospis’ I. Petlina i statejnyj spisok F. I. Bajkova). Nauka.

Franke, W. 1968, An Introduction to the Sources of Ming History. University of Malaya Press.

Haltod, M. 1966, Mongolische Ortsnamen. Zusammengestellt aus mongolischen Manuskript-Karten. Mit 26 Lichtdrucktafeln. Mit einer Einleitung von W. Heissig. T. 1. Steiner. (Verzeichnis der orientalischen Handschriften in Deutschland; Supplementbd. 5/1.)

Hambis, L. 1969, Documents sur l'histoire des Mongols à l'époque des Ming. Presses Universitaires de France. (Bibliothèque de l'Institut des Hautes Études Chinoises 21.) 
Heissig, W. 1944, Über mongolische Landkarten. Teil 1, Monumenta Serica Vol. 9 (1944), 123-173.

Hucker, Ch. O. 1958, Governmental Organization of the Ming Dynasty, Harvard Journal of Asiatic Studies Vol. 21 (1958), 1-66.

Hucker, Ch. O. 1998, Ming government. In: The Cambridge History of China, ed.

D. Twitchett, F. W. Mote, Vol. 8. The Ming Dynasty, 1368-1644, Pt. 2, Cambridge University Press, 9-105.

Lewicki, M. 1949, La langue mongole des transcriptions chinoises du XIVe siècle. Le Houa-yi yi-yu de 1389. Édition critique précédée des observations philologiques et accompagnée de la reproduction phototypique du texte.

Nakładem Wrocławskiego Towarzystwa Naukowego. (Prace Wrocławskiego Towarzystwa Naukowego. Ser. A 29.)

Manduqu, Ö 1995, Mongyol I iui toli bičig [The Mongolian Glossaries Yiyu].

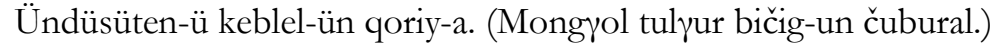

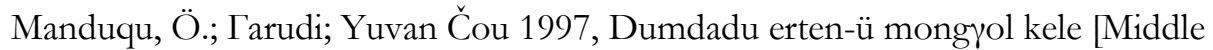
Mongol]. Liyooning-un ündüsüten-ü keblel-ün qoriy-a. (Bükü ulus-un degedü suryayuli-yin jijaqu materiyal.)

Mao Yuanyi 茅元儀 1995-2002, Wu bei zhi 武備志. Erbai sishi juan 二百四十卷 [Notes about Military Preparations. In 240 juan]. In: Xuxiu Siku quanshu 續修 四庫全書 [Enlarged and Revised Complete Library in Four Sections]. Vol. 963-966. Zibu 子部 [Masters]; Bingjia lei 兵家類 [Military Treatises]. Shanghai guji chubanshe 上海古籍出版社.

Mao Yuanyi 茅元儀 2000, Wu bei zhi 武備志. Erbai sishi juan 二百四十卷. Ming Tianqi keben 明天啓刻本 [Notes about Military Preparations. In 240 juan. A Ming Xylograph from the Tianqi [Period] (22 January 1621-4 February 1628)]. Beijing chubanshe 北京出版社. (Siku jinhui shu congkan 四庫禁㲜書叢刊 / Zibu 子部 23-26.)

Murzaev, E. M. 1996, Tjurkskie geografičeskie nazvanija. Vostočnaya literatura.

Niu Pinghan 牛平汉 1997, Mingdai zhengqu yange zongbiao 明代政区沿革综表 [General Tables of Historical Changes in Administrative Divisions of the Ming Period]. Zhongguo ditu chubanshe 中国地图出版社.

Pelliot, P. 1925, Les mots à h initial, aujourd'hui amuie, dans le mongol des XIII ${ }^{\circ}$ et XIVe siècles, Journal Asiatique T. 206 (1925), 193-263.

Pelliot, P. 1927, Le prétendu vocabulaire mongol des Kaitaḳ du Daghestan, Journal Asiatique T. 210 (1927), 279-294. 
Pelliot, P. 1948, Le Hुōja et le Sayyid Husain de l'Histoire des Ming, T’oung Pao Vol. 38 (1948), 81-292.

Pozdneev, A. M. 1896-1898, Mongolija i Mongoly. Rezul'taty poezdki v Mongoliju, ispolnennoj v 1892-1893 gg. T. 1-2. Tipografija Imp. Akademii Nauk.

Pozdneev, A. M. 1908, Lekcii po istorii mongol'skoj literatury. Vol. 3. Tipolitografija pri Vostočnom Institute.

Rachewiltz, I. de 1977, Introduction. In: Mostaert, A.: Le matériel mongol du Houa i i iu 華夷譯語 de Houng-ou, T. 1, Institut Belge des Hautes Études Chinoises, VII-XXIII. (Mélanges Chinois et Bouddhiques 18.)

Rykin, P. O. 2007, Kitajsko-mongol'skij slovar' načala XVII v. 鞋靼語 Dada juj 'Tatarskie slova': vvedenie v izučenie pamjatnika. In: Problemy istoričeskogo razvitija mongol'skih jazykov. Materialy meždunarodnoj naučnoj konferencii (Sankt-Peterburg, 24-26 oktjabrja 200 g.), ed. P. O. Rykin, Nestor-Istorija, 112-126.

Rykin, P. O. 2012a, Kitajskaja transkripcija mongol'skix veljarnyx i uvuljarnyx soglasnyx v slovare Dada juj/ Bejlu ijuj (konec XVI-načalo XVII v.). In: «Živem družno, "molodye" raznogo vozrasta». Sbornik statej v pamjat' vostokovedatjurkologa A. N. Samojloviča, ed. A. D. Vasiljev, S. V. Dmitriev, Probel-2000, 87-120.

Rykin, P. 2012b, On the principles of Chinese transcription of Mongolian sounds in the Sino-Mongolian glossary Dada yu / Beilu yiyu (late 16th-early 17th century), Acta Orientalia Academiae Scientiarum Hungaricae Vol. 65 (2012), 323-334.

Serruys, H. 1955, Sino-Jürčed Relations during the Yung-lo Period (1403-1424). Harrassowitz. (Göttinger Asiatische Forschungen 4.)

Serruys, H. 1959, A Mongol Settlement in North China at the End of the 16th Century, Central Asiatic Journal Vol. 4 (1959), 237-278.

Serruys, H. 1982, Mongyol: Moyal and Mangyus: Mayus, Acta Orientalia Academiae Scientiarum Hungaricae Vol. 36 (1982), 475-484.

Serruys, H. 1983, Bayan Süme: Mongol name of Hsüan-fu, Ural-Altaische Jahrbücher. Neue Folge Bd. 3 (1983), 166-169. 



\title{
The Manchu-Mongolian letters between Tibet and Qing-China from the collection Daicing gürün-ü mongyol bicig-ün ger-ün dangse
}

\author{
Andreas Siegl (Ludwig-Maximilians-Universität München)
}

\section{Introduction}

In the following short paper, I will give you a brief presentation of the published

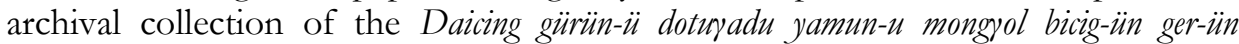
dangse, introduce some research that has been done with this source up to date, and use a very small case study to suggest how one can use this source to still do political history in the 21 st century.

\section{Source}

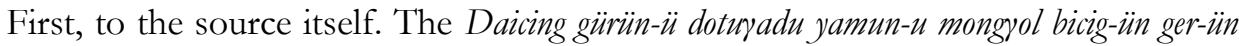
dangse (Chin. Qing Neige Menggutang dang 清內閣蒙古堂檔, from now on QNMD) was published by the First Historical Archives in Beijing in 2005 and has 22 volumes of around 500 pages each, plus helpfully one index of contents in Mongolian. The documents in these volumes are taken, as the name suggests, from the Chancellery for Mongolian of the Qing dynasty's Grand Secretariat, ranging from 1671 (Kangxi 10) to 1723 (Yongzheng 1), thus spanning around 50 years. ${ }^{1}$

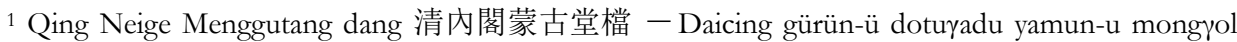
bicig-ün ger-ün dangse, 2005, Neimenggu chubanshe (Forthwith as QNMD).
} 
The language of the documents is Manchu and Mongolian, or just Manchu. The documents are edicts and memorials to the throne from officials working on the border and foreign leaders like Galdan and Cewang Rabtan of the Dzungars, the Dalai Lamas of Tibet, and others. Those letters were usually routed through the Colonial office of the Qing, the Lifanyuan. The Neige took to translating the texts: Sometimes, the originals of the memorials were in Tibetan, oftentimes in Mongolian or Manchu, while in the case of the edicts, Manchu was probably the original language. After translation, a decision was made concerning memorials and an edict was was sent back as answer. All those documents were thereupon stored in the Neige. Most often, the texts that were stored seem to have been orderly rescripts of the original letters. The contents are usually of the highest political order, for example concerning - in the case of Tibet at the turn of the 17th to the 18th century - the questions of an aborted visit of the Panchen Erdeni, of the authenticity of the various 6th Dalai Lamas, and what will be investigated shortly below, a border dispute about the region of Dajianlu in Kham.

\section{Research}

Secondly, to the research based on the QNMD: Up to date, the works that I have found that deal with this source can be broadly put in two categories, both of them approaching the QNMD with a historian's perspective: A broader approach that puts a scholarly question front and center, and a more narrow approach, that - at least to me - seems to bring the source itself more into focus and develop a theme going from there. For the first group - with a scholarly question at its center - we have the admirable work of former students of Mark Elliott in Harvard, most notably David Brophy, as for example in his recent article on "The Junghar Mongol Legacy and the Language of Loyalty in Qing Xinjiang"2 and also the Japanese scholar Onuma Takahiro in his work on the rise of Emin Khwaja. ${ }^{3}$ In the works of these scholars the QNMD are only a small part of a multitude of sources, in a myriad of languages, drawn together to paint a picture of the Qing conquest of and expansion in today's Xinjiang.

On the other hand, we have more source-focused work, most notably by Oyunbilig and to some extent also in a $2009 \mathrm{PhD}$ thesis from Baoyintegusi at Neimenggu daxue, ${ }^{4}$ where the texts of the QNMD stand front and center. Oyunbilig has demonstrated in a series of articles, among other things, that the wellknown enmity between the regent (Tib. Desi or Ma./Ch. Diba 第巴), the de-facto

\footnotetext{
2 Brophy, D. 2013, The Junghar Mongol Legacy and the Language of Loyalty in Qing Xinjiang, Harvard Journal of Asiatic Studies Vol. 73. (2013), No.2, 231-258.

${ }^{3}$ Onuma, T. 2012, Promoting Power: The Rise of Emin Khwaja on the Eve of the Qing Congquest of Kashgaria. In: Occasional Paper No.57, Research Institute for Oriental Cultures Gakushuin University, 31-60.

${ }^{4}$ Baoyintegusi 宝音特古斯, 2009, Shiba shiji chuqi Weilate, Xizang, Qingchao guanxi yanjiu: Yi "Liu shi Dalai Lama shijian" wei zhongxin, Ph.D. thesis, Neimenggu daxue.
} 
ruler of Tibet at the end of the 17th century and the ruler of the Qošot-Mongols, Lazang han, did emerge well later than it was originally thought. The Desi was actually instrumental in putting Lazang in place as ruler. ${ }^{5}$ He reached these conclusions by doing a close reading of the QNMD, and this is an approach I am using in my $\mathrm{PhD}$ thesis, soon to be published. In the course of my own research, I have looked at three different episodes in the relation between Gelug, Qošot and Qing: The failed wish of the Kangxi emperor that the Panchen Erdeni should come and visit Beijing, a border dispute about the ethnically Tibetan town of Dajianlu, and the fight between Lazang han, fellow Qošot, various Tibetan dignitaries and the Qing about who - of two candidates - should be considered the real, the authentic Dalai Lama.

\section{Case study - The fight for Dajianlu}

I will quickly introduce case number two - the fight for Dajianlu - and how it is mirrored in some parts of the QNMD. Dajianlu (Ma./Chin. Dajianlu 打箭爐, tib. Dartsedo), called Kangding 康定 today, was a small town and county between ethnically Tibetan and Chinese areas. In the 17th century, it was directly controlled by local Tibetan chieftains who, since the rise of the 5th Dalai Lama a few decades earlier, were obliged to pay tribute to Lhasa. At least since the time of the rebellion of the Qing warlord Wu Sangui, since around 1663, there was a presence of Chinese troops in that area as well. With its key position on one of the few roads from Chinese lands to the Tibetan highlands, Dajianlu occupied an important role in the trade along this route and was most likely an important source of income for the Gelug. At the end of the 17th century, more aggressive leaders of the Qing were appointed in that area, which in turn lead to a military build-up by the Qing, which in turn lead to a Tibetan build-up, which in turn lead to the killing of a local chieftain of dubious loyalty by the Tibetans. This caused an embargo of trade in that area by the Qing, and finally attacks of Qing troops. This situation was summed up well in a longer letter in the QNMD that mostly dealt with other topics, but where this fight for Dajianlu slowly came into focus. Here, the Kangxi emperor berates the regent for various crimes against the Qing, not least of which was the use of Tibetan troops around Dajianlu: ${ }^{6}$

'When one considers this: Didn't you secretly order your subordinates to encroach on our border regions, thus instigating this whole affair? When one moves the border regions by balf an inch, can that be? Apart from the fact that all of this is due to your obstinate behaviour, it is not something that has happened through my instigation."

5 Oyunbilig 乌云毕力格, 2008, 1705 nian Xizang shibian de zhenxiang, Zhongguo Xizang Vol. 3 (2008), 82-91.

${ }^{6} \mathrm{QNMD}, 118$. 
"erebe tuwaci sini harangga niyalma de dorgideri tacibufi . mini jase jecen be necime. baita dekteburengge wakao .. jase jecen $i$ babe emu urgun seme anabume buci ombio . ere jergi babe gemu si jurceme yabuha dabala . mini dektebuhengge waka."

While this letter was still framed in the context of other discussions - a characteristic of this kind of documents - the border dispute soon took center stage and pushed all other problems to the side, or so it seems. And at that time, around 1700, the capabilities of the Qing to project power that far from the 18 provinces were already quite large. The Tibetan soldiers were not able to drive off the troops of the emperor and the trade embargo continued. In another edict, the emperor accuses the Desi of claiming the regions around Xining and Lanzhou as Tibetan territory (si ning . lan jeo $i$ jergi ba be tubet $i$ ba bihe seme), which the regent denies and to which he responds that the Tibetans in the region of Dajianlu have been ordered to not provoke the Qing troops (da jiyan lu $i$ jecen de tehe tubet $i$ niyalma be ejen $i$ harangga niyalma be ume necire seme fafulaha). But guilty of starting the whole affair were still men of the emperor. This discussion goes on and on over quite a few letters. While the Dalai Lama and the regent finally concede that it might have been their mistake (waka be alime), they still demand that the region should be brought back under Tibetan control, and what seems even more important to them in the texts, that the trade embargo should be lifted. And finally, in a rhetorical turn brought about by the Panchen Erdeni, the topic of his own aborted visit which had strongly rankled the emperor, was mentioned as a possible reason for the Qing's uncompromising stance in this territorial dispute: ${ }^{7}$

"That a bit of trouble occurred in Dajianlu, and that the territory there was taken by the Qing7, was that for the reason that I did not come? Or did this happen because the people living in that place failed being harmonious? In any case, a messenger was sent, asking for the Lord's forgiveness, pleading: Can the place of Dajianlu - just like the time of the 5 th Dalai Lama, when it was ruled by Tibetan chieftains - be given back to Tibet?"

"da jian lu ergide majige becen banjinaha. ba na be gairahangge . mini beye genehekûu tur-gun biheo . eici tere ergide tehe urse hûwaliyasun be ufaraha ci banjinahangge biheo . ai ocibe . damu ejen $i$ šar seme gosire be baime elcin takûraha . bairengge. da jian lu i ergi babe sunjaci dalai lama bihe songkoi tubet $i$ da ejelhe ba be kemuni tubet de bureo."

So here we have a completely new reason for the whole fight about this region brought into play: The Panchen had previously said that he would visit Beijing, but soon afterwards he had asked the emperor's permission not to come. The reasons given for that were, that he had not yet had smallpox and that he did not possess enough learning. This dispute went back and forth with an increasingly angry Kangxi emperor, who suspected the regent of being behind the Panchen's refusal, but in the end the Qing couldn't convince the Panchen to visit them. So, how can

${ }^{7}$ QNMD 16, $511 \mathrm{f}$. 
one connect this information about this historical non-event and its reoccurrence with our border dispute?

One way to evaluate the role of this new topic - or old topic, if you will, as this discussion seemed already finished - is by using a pretty simple concept, namely that of "political reality" in the sense used by Gerhard Althoff. This term derives from a discussion in mediaeval studies about the historical truth of accusations made by contemporaries against the Holy Roman Emperor Henry IV. Althoff's argument in this case is that even if the truth about his sexual perversions and other perpetrations cannot be ascertained, simply by being uttered, they became a part of "political reality" in that time and influenced the political climate. ${ }^{8}$ In his case, Althoff still ascribes a certain historical truth to these accusations. But for my presentation, the critique by Philippe Buc of Althoff's position in this regard is helpful: "it is of no relevance, whether the misdemeanors of Henry were real or imagined, as they became part of public debate and thus part of "political reality."

What is the purpose of this short excursion? Well, to show the use we can make of information in the texts that might not be considered important at first, because in the grander course of events, they did not seem to matter. But if we focus on the context, the "political climate" of the Panchen's utterance about his failed visit, we see the fear of the Gelug, be it the Panchen, or more importantly at that time, the regent, of having gone too far in provoking the emperor. Whether this inquiry for the failed visit of the Panchen was a sincere question, or mere posturing, it still showed that the Gelug saw this as a topic they had to address, that this was now part of "political reality." And it also showed that the failed visit was now considered as something that might have repercussions that were not deemed plausible a short time ago. I sadly do not have more space to fully flesh this out, but to sum it up, for me the great strength of close reading of a source like the QNMD lies in the fact that one can immerse oneself fully in the "political reality" of Sino-Tibetan relations of that time, whether the statements contained therein had a historical truth to it or not.

\footnotetext{
8 Althoff, G. 2006, Heinrich IV., WBG, 17-21.

9 Buc, P. 2010, Die Krise des Reiches unter Heinrich IV., Mit und ohne Spielregeln, In: Spielregeln der Mächtigen: Mittelalterliche Politik zwischen Gewohnheit und Konvention, ed. Claudia Garnier, WBG, 63.
} 



\title{
The Nobility of the Altai Urianhai Banners in Archive Documents and Oral Tradition
}

\author{
Ondrej Srba (Institute of South and Central Asia, Faculty of Arts, Charles \\ University in Prague)
}

\section{Introduction}

The Altai Urianhais are a culturally Oirat Mongolian ethnic subgroup which during the Qing period formed a distinctive administrative region of the Seven Banners of the Altai Urianhais subordinated to the Manchu amban in Khovd (and, respectively, to the amban in Altai Sir-a süm-e since 1906). Three of the banners were Tuvan-speaking, and their descendants identify themselves as Tuva (in PRC, this still falls within the Mongolian nationality), although the cultural differences between Mongolian and Tuvan-speaking Altai Urianhais are insignificant. In consequence of the Russian-Chinese declaration (1913) and the Treaty of Kyakhta (1915), the area of the Seven Banners was divided between Xinjiang and Mongolia, which brought a quick decline of Altai Urianhai populations on both sides of the new frontier, succeeded by several transfrontier and internal migrations, and precipitated as well by the immigration of Kazakhs.

The historical oral tradition of the Altai Urianhais is centred around the history of the banner nobility. The governors of the Altai Urianhai banners did not have any origins in the Eastern Mongolian Golden Clan or the Dzunghar nobility, nor was their hereditary succession confirmed by the Manchu court in the Iledkel sastir ${ }^{1}$

\footnotetext{
${ }^{1}$ Note on transcriptions: When transcribing archive documents, historical terms and names taken from written sources, I use the transcription of the Classical Mongolian script. When transcribing oral
} 


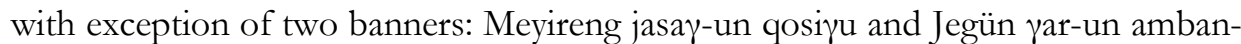
$\mathrm{u}$ qosizu. In the administrative division of the Altai Urianhais created between 1762-1839, after the submission of Altai Urianhais to the Qing empire in 1754, the last-named banner presided over the Left wing of Altai Urianhais; the rank of governor was named sula amban, ${ }^{2}$ while the title sula amban of the Right wing was usually held by the hereditary governor of the easternmost banner (Banner of Darqan beyise during the period of Autonomous Mongolia). The other Urianhai banners were governed by general directors bügüde-yin daruy-a (uheri da), but all of them were in fact hereditary at least until the end of the 19th century.

My research is based on a study of archive documents in the funds of the Altai Urianhai banners in the National Central Archive of Mongolia, and on continued research of oral tradition among Altai Urianhais in Western Mongolia (Hovd and Bayan-Ölgii aimags) and Xinjiang (Altai qota).

\section{Local archives}

As in the case of archives from Western Mongolia, the archives of the Altai Urianhai banners were destroyed with exception of few documents. The document collection concerning the Altai Urianhais in the National Central Archive of Mongolia ${ }^{3}$ contains occasional documents starting from the Törü gereltü (Daoguang, 1820-1851) era, followed by more frequent documents from the Badara (Guangxu, 1871-1908) era. Almost all the documents originated from the Left wing. Most of these documents are contained in the collection M-163 (Алтай Урианхайн зүүн гарын бүгдийн даргын жасаа).

The oldest document is dated 1835: it is a register of dependants of the Meyiren-ü janggi-yin qosi $\gamma u$ (Delgerekü noyan, who governed the banner 18221838) who are required to provide taxes in furs of sables and foxes. ${ }^{4} \mathrm{~A}$ similar register is available from 1846.5 Documents concerning levies of horses, camels and other necessities for the functioning of örtïge communications are preserved from $1880-1886 .{ }^{6}$ The most frequent documents are of a demographic character. The most extensive one is an undated census describing the populations of Jegün

\footnotetext{
sources and writing names related to the oral sources I use a combined transcription based on the orthography of Modern (Cyrillic) Mongolian with respect to major dialect features. The apostrophe marks the front vowels $\left(\mathrm{o}^{\prime}=\Theta, \mathrm{u}^{\prime}=\mathrm{Y}\right)$ only in the first syllable (with regard to vowel harmony). Bibliography and quotations from texts written in Cyrillic remain in Cyrillic.

2 Originally a title of the imperial court (Chin. san₹bi dachen 散秩大臣), this title designates the grand minister assistant commander of Imperial Guardsmen.

3 Монгол улсын ҮнАэстний төв архив.

${ }^{4} \mathrm{M}-163$, A-1, XH-1.

${ }^{5} \mathrm{M}-163, \Delta-1, \mathrm{XH}-2$.

${ }^{6} \mathrm{M}-163, \Delta-1, \mathrm{XH}-5$.
} 
amban-u qosiju and Qar-a soyun-u qosiju (with uheri da Sengdünjab). ${ }^{7}$ In addition, this detailed census mentions clan names of individual families, places of residence and their main occupations - nomadic pastoralism, agriculture or hunting. The census was updated two years later, which is obvious from the age data given; all the families resided in the same place as they had been two years ago. It refers to a fact that the populations of the northern and the southern sides of Altai were generally fixed, and did not migrate periodically as was more common in the eastern Left wing of Altai Urianhais. This is also confirmed by oral history from both sides of the Altai range, which regards the two populations as two distinguished entities within one banner administration. Some documents concern the migration of $\mathrm{Ka}$ zakhs: the first one is a famous letter from 1839 issued by sula amban Darma-azar of the Left wing to meyiren-ü janggi Čebegdasi reporting that the army of Sayin noyan has expelled Kazakhs from the territory of Altai Uriankhais, and ordering him to strengthen forces in the border patrol areas. There is only one sample of a continuous cartulary (bicig-i qayuluysan dangse) from the Qing era (1891-1895) ${ }^{8} \mathrm{kept}$ by sula amban Erkešonu (governed banner 1891-1913).

The right wing banners in the Manchu period are represented only by a few documents originating from the Banner of Yosutu güng (unofficially the Banner of Köke Mončay), while all the archives of the Right wing Banner of sula amban were completely lost to fire when the banner office was temporary on the territory of the present Ćinggel (Xinjiang). The Banner of Yosutu güng is also the only one with a preserved document collection from the periods of Autonomous Mongolia and the first decade of the Mongolian People's Republic. ${ }^{9}$ It includes also some documents from the Governor office of the Altai Circuit in Xinjiang (新疆可山道尹公署, Sin-e muji-yin Altai ayula-yin Do yin yamun) dated 1917-1920 and written in the Clear script.

The archive of the short-lived Banner of Dambiijantsan, containing lists of dependants presented to Dambiijantsan by Urianhai governors (A-135: Аамбийжанцангийн хувийн ба шавь хошууны тухай цуглуулга), demands special attention. The archives of higher authorities with major significance for research concerning the Altai Urianhais include: A-128: Аөрвөдийн баруун гарын Үнэн зоригт хан аймгийн чуулган Ааргын жасаа, А-141: Баруун хязгаарыг илбэн тохинуулах сайА; А-144: ХовАоА сууж хэрэг шийтгэгч сайА; А-146: Баруун хязгаарыг байцаан Үзэж, сэргийлэн батлах сайА.

\footnotetext{
${ }^{7}$ M-163, A-1, XH-3. According to the age of Sengdünjab noyan as mentioned in the census (he was born presumably in 1883), it can be concluded that the older part of the census originated in 1908, and the second in 1910.

8 М-161: А^тай Урианхайн сул амбаны тамгийн жасаа.

9 A-130: АөрвөАийн баруун гарын ААтай Урианхайн Ёст засгийн хошуу and Ф-62: ААтай урианхайн Ёст засгийн хошуу.
} 


\section{Oral tradition}

The living oral tradition of Altai Urianhais covers almost the same period as the local archive documents (i. e. narrating events beginning in the second part of the 19 th century). It created a complex of genealogies and narratives around individual members of the local nobility (banner governors, sumun janggi, jakiruүči, kündü etc.). In many cases, the oral genealogies are the only source for the sequence of banner governors, since the Iledkel sastir of the Bogd Khaan period contains only two lineages and preserved archive documents are scarce. The oral genealogies, especially in the case of the older generations, prefer to use familiar rather than official names of the governors and other officials. Therefore, the oral genealogies are difficult to apply to names from written documents and thus come to resemble a part of local mythology.

\section{Archives and Oral tradition: A comparative case study}

As an example, I would like to discuss the genealogy of the governing family of the Banner of Barayun amban. Only a minimum of archive materials related to this banner has been preserved in the archives of other banners (mainly Yosutu güng) and higher authorities.

\subsection{Genealogy of the Banner of Baruun amban}

The most complete genealogy has been preserved in the memory of the direct descendants of this noble family, who live in Činggel in Xinjiang: Zandavaanii Majig and his nephew Batučayan (Beken). The oral tradition in Bulgan sum (Bayan-Ölgii aimag), recorded by Puncagdorž, mentions Nariin har as the first known governor of the banner. A representative of the contemporary living oral tradition in the northern part of the former banner, B. Handžav (born 1926), mentioned Sayinbilig as the first amban, admitting that she had heard about the earlier governors in her childhood.

Table 1: List of governors of the Barayun amban's banner according to oral tradition

\begin{tabular}{|l|l|l|}
\hline Batučayan, Maji (Činggel) & Пунцагдорж (1999: 14) & В. Handžav (Mo'nhhairhan) \\
\hline Ildeng qar-a amban & - & - \\
\hline Čering tayiji & - & - \\
\hline Naran qar-a amban & Нарийн хар & $?$ \\
\hline- & Хилэн хар буюу Аэлэг ноён & - \\
\hline
\end{tabular}




\begin{tabular}{|c|c|c|}
\hline- & Сайнбимэг & Sainbilig amban \\
\hline Sambuu tayiji & Самбуу тайж & Sambuu taiži \\
\hline - & $\begin{array}{l}\text { [out of the lineage: Аашцэвэг } \\
=\text { Жоожоо амб̆ан] }\end{array}$ & [Dasičebeg = Žooža amban] \\
\hline $\begin{array}{l}\text { Dambadorji, Baldandorji, } \\
\text { Čültüm da lama (held rule } \\
\text { instead of Jamiyangjab) - sons } \\
\text { of Sambuu tayiji }\end{array}$ & $\begin{array}{l}\text { Аамбадорж, Балдандорж, } \\
\text { Чүлтэм даа Аам }\end{array}$ & $\begin{array}{l}\text { Baldandorž, Ču'ltem da lam (no } \\
\text { mention of Dambadorž) }\end{array}$ \\
\hline Jamiyangjab & Жамъянжав & Žamiyangžav noyon \\
\hline
\end{tabular}

The first governor of the later Banner of Barayun amban mentioned in written sources is Molomdarjiya, who was listed in a 1823 redaction of Qobdu-yin jasay-un kereg-ün bügüde čese 科布多事宜, ${ }^{10}$ and in a document dated 1812 found in the archive of the Manchu amban in Ikh Khüree (Küriyen-dü sayuju kereg sidkegči manju sayid). It is a Manchu travel permit for a group of pilgrims to Yeke küriy-e headed by jalan-u janggi Sonumdarjiy-a. ${ }^{11}$

The next known mention of a governor of the Banner of Barayun amban dates from as late as $1891 .{ }^{12}$ Sayinbeleg is mentioned as the sula amban of the Right wing of Altai Urianhai (Altai uriyangqai-yin barayun yari jakirqu qoyar jerge nemegsen sula amban), while the seal impression used by Sayinbeleg reads "The seal of the directorgeneral of the Right wing of Altai Urianhai" (Altai-yin Uriyangqai-yi jakiruyci barayun yar-un bügüde-yin daruy-a-yin tamay-a), as it was bestowed upon the Right wing at the time when only one eligible director-general for the three banners was officially recognized by the Manchu authorities. At the same time, Sayinbeleg is the first governor, who can be identified by oral tradition. Oral tradition concerning Sayinbeleg, however, is limited to a faint reminiscence that he was an ideal and virtuous governor.

Sayinbeleg's son, Sambuu taiži, is not mentioned in archive documents. According to oral tradition he lacked the ability to become a governor probably due to a mental disorder (Handžav) or because he had only one eye (Пунцагдорж 1999: 14). Handžav describes him as a corpulent man and a good wrestler (beyerheg buumarhag bo'k ku'mun bai y. Handžav mentioned that Sambuu was killed by Kazakhs when he was carrying a jug of alcohol (dombtoi arib) to the monastery and

\footnotetext{
10 Qobdu-yin jasay-un kereg-ün bügüde čese 科布多事宜 (富佾等輯, 1823: uheri da Molomdarja. Isün-ü këbegün.

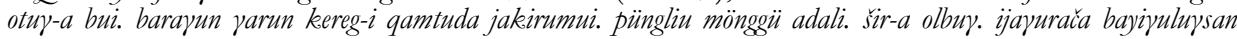
sumun-u janggi tabu. Sayisiyaltu irügeltü-yin jirrudupar on kebei amban $Z^{\prime} e$ yuyun ayiladqaju nigen jalan janggi nemebe. nigen yarun kereg-i tusalan sidkemüi. cerig dörben jayun yiren dörbe. sula nigen jayun yurba. lama tabin dörbe.

${ }^{11}$ Facsimile in Чулуун 2011: 26-27.

121.) M-161, A-1, XH-1, fol. $2 \mathrm{v}-4 \mathrm{v}$ (Sayinbeleg makes a report about the outlines of Altai Urianhai area). 2.) $M-163, \Delta-1, X H-9$, (Sayinbeleg forwards to Meyiren-ü janggi Sambuudorji a report by bügüde-yin daruy-a Idamjab about a grievance by Mami, a ruler of Tarbagatai Kazakhs, 28.8.1891).
} 
thrown into the river Örönggö. Puncagdorž (1999: 14) ascribes this incident to Sambuu taiži’s eldest son Dambadorž (unknown to Handžav).

After Sambuu tayiji, oral history speaks about Dašceveg, who was assigned to administrate the banner in place of the young sons of Sambuu tayiji. Dašceveg, known by the locals by the honorific address Z̆ooža amban, tried to pass his office onto his own sons (Šar zalan, Gotov Corž). However, the lower nobility of the banner requested the restitution of the original ruling clan - Ih holdon elkin. This history, which proves the importance of the noble origin of the banner governor in Urianhai society, is known only from the oral tradition. According to oral tradition, one resident of the banner called Šolog Šonghor refused to obey Dasičebeg as a low-born person and chose to escape to the interior of Xinjiang:

Уггуй жинстэй

Олон чоохор морьтой

Отау тарвага шүдтэй

Ноён чамд би захирагдахг $\ddot{u}^{13}$
With dignity without noble birth, with many spotted horses, with teeth like a tarbagan, I won't surrender to you, lord.

Šonghor described the unaccustomed life in the Chinese environment in rhymes:

Чин хар уай ундтай

Чийгтэй мантуу хоолтой

Чи мад хэлтэй

ХэиҮY нутаг байжээ ${ }^{14}$
Drinking only black tea (without milk), eating just moist mantou, speaking "chi mad", these were people difficult to live among/ this was a hard place. ${ }^{15}$

and he returned to his home-place only after the death of Žooža amban.

Sambuu tayiji's second and third sons Baldandorji (1879/1883?-1915/1916) and Č̈̈ltüm da lama (1886-1942) became monks, ${ }^{16}$ but were subsequently asked to leave the monastery to take over the administration of the banner. Baldandorji is described as an ideal wise ruler, who died 33 years old. ${ }^{17}$ This was considered a sign, i. e., he died by "the dream of Qurmusta tngri”" (Hurmustiin ₹u'udeer nas barsan ku'mun; Handžav), meaning that his life was but just one dream of Qurmusta tngri. He is praised for his fearless attitude towards Ja lama Dambijancan.

\footnotetext{
13 Пунцагдорж 1999: 15. Cf. version by B. Handžav: Šonghor gedeg ku'mun: uggu'i beyetei $c$, 
Baldandorji (died 1915/1916) was succeeded by his son Jamiyangjab (1902?1968), but Baldandorji's younger brother Čültüm da lama acted as his regent, as Jamiyangjab had a stutter (he was called Eeruu noyon) and was not able to govern the banner. As early as 1916, Čülüm da lama submitted to Chinese republic authorities in Ürümči and Altai-yin Sir-a süm-e, and did not support the Mongolian government in Yeke küriy-e until 1924, when he became a member, with great conviction, of the Mongolian People's Party. In 1927, he was elected as chief of the recently united Banner of the Right Wing of Altai Urianhais. He participated as a representative in the 11th State small bural in 1928 and was designated "commissaire."

In oral history, Čultem da lama is described as an ideal governor, who at the right moment - the second half of 1920s - understood the importance of the people's government, relinquished his properties and position, and tried to stop the lower nobility (sumun-u janggl) from executing their plan of encouraging migration to Činggel in Xinjiang. Cültüm da lama's image from this decade in the archive documents, however, is far more complicated. At the beginning of the 1920s he acted as a trustful supporter of the Republic of China according to the official correspondence sent by Čültüm da lama to the subordinated banners, while in the protocols of the annual conventions of the Altai Urianhai aimag (1925-1927) he expressed his hope that the peoples government would establish an ideal society in the Buddhist sense. The role of Cültem da lama in the migration of the banner into Xinjiang in 1930 is a moment of a total disaccord between the archive documents and the local tradition that has not yet been clarified.

\subsection{The wedding of Jamiyangjab noyan}

The wedding of Jamiyangjab noyan with a Torguud princess is a popular and important story in the local oral history of Bulgan and Mo'nhhairhan sums. It speaks about the role of a special group of non-monastic religious experts in the society and provides evidence concerning the relations of the neighbouring banners and ethnic groups in Western Mongolia. Furthermore, this story helps us to understand how the Urianhais traditionally apprehended the links between the deeds and conduct of the nobility, the welfare of commoners and the natural landscape as equal to the local deities (savdag).

The wedding presumably took place in the second half of the year 1910. Oral tradition varies in the reasons for the dispute which caused the death of the Torguud princess and subsequently the tragic decline of the Torguud banner during the next few decades. The oral tradition from Bulgan and Mo'nhhairhan (information from Banzariin Handžav, Aravžaan Čadraabal, Sodnomiin Baldaa, Cogtbayariin Šarhu'u, Zodoviin Tavitai, Namaraliin Orolmaa, Šilegiin Gerelčuluun; here represented by the version of Banzariin Handžav) emphasizes the impact of the malediction given by Har (Žamiyan) Tangad, ordered by the Torguud noyon as a response to the Urianhais' impoliteness and lack of courtesy at the court of the 
Torguud wang. On the other side, the oral tradition in Činggel (represented only by a single, but very reliable version from the direct descendants of the banner's ruling clan) emphasizes the role of the curse placed by Badai gu'n (Badraqu güng)

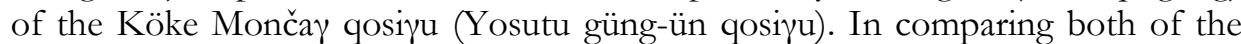
local versions, I would conclude that in the original version Badai gu'n may have acted as the official deputy of the Baruun amban to Torguud wang to ask for a spouse for Žamiyangžav and to hand over the ceremonial gift of the Nine Whites. I consider the malediction of Har Tangad a response to the curse placed by Badai gu'n.

\section{Oral version from Mo'nhhairhan}

Recorded from Banzariin Handžav (re-narrated several times during 2012-2015, here according to the version recorded on 16.6.2014; Bayansai, Mo'nhhairhan, Bortiin bag).

Manai Urianhaigaas garsan šig baisan biš u'u? Ger baisan, tanuusiig avdag ger ene gene gev̌, tegeed zočin hu'leež avdag ger tustai bailgu'i yaah ve. Gal togoonii ger yamar yumnii ger baina. Ter bol manai Urianbain buruu baibgu'i yuu. Tegheer bu'n oroogu'i ger yaagaad barisan kereldeed ekilsen gelee. Ter bol Urianhain burun geč. Zočin bu'leež avdag ger tustai baiž taarnis.

Neg toon arvan zurgaatai, neg toon arvan tavtai, nilk. obin baisiim. Ter noyon hoyor battai baisan. Nam乏̌a noyon, tu'ruunii hatnaas garsan. Nam乏̌aa noyon abii, Nam乏̌a noyon aaviin tom hatnaas garsan bu'ubed.

Ter Har Tangad gedeg yumaar haraal hiilgesen. Tangad gedeg cini ih haraalc baidag. Tegeed Ar modon gež. Bulgan goliig uruudaad, manai Har bu'zunt Du'vǒn gedeg lam baisan. Nadad-

doloon beer har bo's,

beden kil šar tos o'gtun.

Tegeed hurc su'btei mod cav̌áad yav そ̌yavsan. Nad neg hurc su'b o'gtun. Tegeed hurc su'btei mod cavčaad yav̌̌ o'gsu zamdii. Tegeed ene mun yadun ko'gšin, mod cavčdag [gež hu'muns bodson]. Ter ar modon gedgees o'ngorč baigaad, ter okin ih žoroo moritoi, ardii neg dahuul dagsan yavそ̌yavsan. šanagaar, tolgoigoor hatgaž baigaad, unana gežyavna, doroi mundaž baisan, mori-

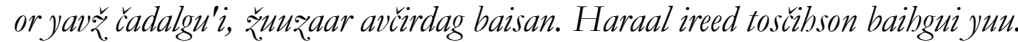

Har bu'zunt du'včind o'gson ter doloon beer har bu'seerii yamar yum bïdeg yum bol. Tu'lee tuimerteed baisan bolnis, [baraaliig] hatand hu'rgunlgui. Hadmïn gert baigaad, nas baraad maani, tegeed sain o'dor cagtiin neg orond oruulsan bolsiim. [Amid baibdaa hatan] noyondaan neg bu'tuun altan bo'gž o'gson. Tegeed yostoi iksiin ko'ld nilhasiin tolhaa o'rovdono geそ̌ tegsen maani.

Har Tangadiin haraal tusaad, ardii manai Cu'ltem da lam o'vdood, mundaad, ter Har ku'zunn du'vöin gedeg ku'mun, ïgiž ïgiž erikeen buruu tu'lkež umšaad, ku'ree gurvan ergunleed, yumtai ko'ocoldood bonož baisan gene: ,[Haraaliig] tun arai gež hariulav. Lamaan lagšn gaigui honov un?" O'vol cag baisan gelee, kirun can togtson malgaigaan bičillicibsen orv" baisan. Ter ažild orolcson amitan nam cugtii munlž baisan gelee. Ter ažild ih su'rkee bu'muns yavž baiz: 
... Hat u'ksnees hoor manai Č́ltum da lam o'vdood, lamaan beye gaigui honov uu? haraaliig arai gež hariulav. Gurvan honog gu'iceež baigaad. .. Haraal nam beyetei ku'mun šingge yavž bolniš, terentei ter Har hu'zunn du'včin caar ergunľ̌ baǐ̌. Gotov [lam], tertei Har Tangad [hargaldaad] 'Tanai Har bu'zunn du'včin bas hecuu šu'u. Ter haraaliig nad yavuulaad, nad iluu širuun irsen. Tegeed odaa Namžaangiin us tasarsan bišun?” gež Tangad helž baisan.

Bag da ik da gedeg baisan, Baidai gu'n gežz. ku'mne hošuu tend yavalcaž baisan. Manai noyonii yavdald orolcož. hamt yavそ̌ baisan bolniš, ter Namžaa noyontoi hereldež baibdaa Namža noyonkiind kelsen: „Minii nutag dotor arvan boyor bo'o baidag, ter dotor cusaar nildag samgan baidag šuu. "Buzartai bolž baina, ter Moňag ik bo'otoi, ter bo'o gedeg čini buzar bolnis.... Tegeed-

„šugund čini u'neg hucuulaad,

o'rh deer čini hon keree dongoduulaad,

totgo deer čini šar šuvun haikruulaad, "Namžaa noyon baahan namdaad baisan gelee. Bičken aigaad, u'g kelebdee bičken togtož baina. Tegeed ter bicken obinïg u'buuleed zogsson bolnis.

Tegeed ter Tagčin geskui gedeg ku'n keľ̌, baisan gelee. „Odoo ene Torgundiin Altain savdag, manai Castiin savdag hoyor hoyuulaa kereldeed, ter hoyor nutug kimraldhaar ene altan delkee terend dagaad kimraldadag boľ̌ baina.

Torgundiin Altain savdgiin nidu'n arvan tamagt haisnii du'ntei,

manai savdgiin nidu'n myangan hoinii hotnii du'ntei gežz. zu'udlev. "Nutag kimraldhaar ter Altain savdag bas zavsartii kimraldah boľ̌ baina.

It was a fault of our Urianhais. [Torguud wang built a special ger for the Urianhain guests. Someone said to them:] "That is a receiving ger for you." "Why did they built a ger especially for us?" It is quite normal to build a special ger for receiving guests. Just like a kitchen-ger and other special gers. It was definitely a fault made by Urianhais.

There was a young woman 15 or 16 years old. Torguud noyon had two consorts and the Namžaa noyon was born from the elder hatan, while the young woman from the other one. So Namžaa was her elder brother.

Torguud wang asked a lama called Har Tangad to release a malediction. Those Tibetans are well-known for cursing. Down along the river, our lama called Har hu'zuut Du'včin has been living. He said: "Give me seven beer of a black cloth and several kilograms of the yellow butter." And he went and started to cut trees alongside the river Bulgan. People were thinking that he was just a poor old man cutting wood for his own self and didn't pay attention to him. When the wedding party [on its way from the lower Bulgan to the upper Bulgan] reached Ar modon the bride rode a gallant ambler horse, followed by her retinue - suddenly a pain in her head started, she fainted and the illness was getting worse quickly. She wasn't able to ride the horse any longer, so they took her in a sedan. She was affected by the malediction.

I don't know what Har hu'zuut du'včin did with the seven beer of black cloths. It is said he was burning some firewood to remove the curse from the bride. But 
she died after all in the ger of her parents-in-law and was buried on a propitious day. When alive, the bride presented to Žamiyangžav noyon a golden ring. [All of it happened exactly according a saying:] "The lords' actions cause the vassals' head ache."

When the [influence of the] malediction came, Cu'ltem da lama also fell ill. Har hu'zuun du'včin came and turned the prayer beads opposite to the usual direction, circumambulated the monastery three times and struggled against something till the morning. It should have happened in winter as he entered [Ču'ltem da lama's ger] with his hat cover by frost, saying: "Did you sleep well, venerable lama? I have hardly kept the curse off." Everyone who participated in the wedding got sick.

... Gotov lam met Har Tangad, who said: "Har hu'zuun du'včin is really skilful. He sent the curse back to me stronger than I sent it. Wasn't that the cause why the banner of Namžaa wang finally dissolved?"

There was a Small Director and a Big Director among our Urianhais. One of them was the Banner of Badai gu'n, which kept relations with our banner. [Badai gu'n] accompanied our noyon to the wedding. He argued with Namžaa noyon: "I have twelve shamans, one of who is an old woman weeping blood." So impure, the Mončags have many shamans. A shaman is a very impure being.

[He continued cursing:] "Let a fox bark in the corner of your ger,

let a raven croak on the smoke hole of your ger,

let an owl howl on your door jamb." Namžaa noyon was put out of countenance and calmed down. After the young girl died, they ended their dispute.

A man called Tagčin geskui said: "Altai Savdag of Torguuds and the Snow Savdag of ours also argued at that time. When the people of two banners dispute, nature is also disturbed. I have dreamed that -

the Altai Savdag of Torguuds has eyes big as ten bronze kettles,

our Savdag's eyes are big as thousand sheep enclosures." When the people come into disorder, nature is also disturbed.

\section{Oral version from Činggel}

Recorded from Kakaanii Bekeen (Batučayan) and Zandavaanii Mažig in Činggel siyan, Xinjiang (20.1.2013). Zandavaa tuslagč was a younger brother of Čültüm da lama and the uncle of Jamiyangjab noyan. The two sons of Zandavaa, Kakaan and Mažig were still alive in 2013.

Yeso'n cagaan ku'rgeed av baisan: yeson cagaan yembuu, yeson cagaan atan, yeson cagaan mo'nggo, yeson cagaan ku'uken, yeson cagaan bulgan, yeson yes nayan negii avčriž, baisan. Bayan omog tiim cag boľ̌ baina daa. Eneeten daraagiin ko'vunn Žamyangžav gež, baisan, Žamyangžaviin hatniig bas ter Torgundiin Cağža wangiin guravdahi u'ye, Šar wangïn ku'ubiig ene Altain doloon hošun Urianbain Badain gu'nii hošunnii Mončagiin - Ko'k tohaid baina tednee zaluň̌nd bolad bidnee zaluň́nud bulaaldsan bolž baina. Bidne bayan noyan zaagaad, yeson cagaan avaad ku'rgeed avčirehdee, ted yeson cagaan ku'rgunlž čidalgui, hocraad, araasii ongon taviad boľ̌ baina. Tegeed ongon taviad, ter Šar wangïn ku'uken, totgon deer alhaad nas 
barsan, Urianhain hadmiin gert oraad. Ter tubai Žamiyangžă noyon Zee bickeen zeerd gedeg dun zokaasan, 13 bu'legtei.

Manai Mončagiin noyon Torgundiin nutagt haraal tavisan biši, Torgundiin nutgïn geriin bu'sii tasraad oc gež keldeg baina haraal tavisan. To'mor do'roonii senæ̌ịin taslaad deer ni do'rvon hošlontoi geriin bu'siig taslaad oč.

The gift of the "Nine Whites" was expected: nine white ingots, nine white camels, nine white pieces of silver, nine white women, nine white sables etc. Nine by nine ninety one [gifts]. In those times the clan had wealth and honour. The second wedding [after Baldandorži's] was the one of Žamiyangžav. His hatan came also from Torguuds, she was a descendant of the third generation after Čagžaa wang, daughter of Šar wang. The young men of the other one of the Seven banners of Altai Urianhais, Mončag Banner of Badai gu'n from Ko'k tohai, and the young men of our banner were fighting over her. Our noyon managed to present all of the Nine Whites, while the other noyon did not. As he was rejected, he sent an ongon, which made the daughter of Šar wang die as soon as she crossed the doorstep of her Urianhai parents-in-law. Žamiyangžan noyon composed a song "Zee, my little sorrel ...."

Our Mončag noyon placed a malediction on the Torguuds to tear up the belts on Torguud gers. "Let rip up the metal stirrups [of their horses], let tear up the four belts of their gers."

An archive document related to the wedding

The letter without an exact date and name of the addressee is found in the Collection of letters of the Mongolian nobility (M-170) in the National Archives of Mongolia. Owing to the remark that after the arrival of the addressee, the noyons will be discussing the affairs of the three banners (of the Right Wing of Altai Urianhais), it can be supposed that the addressee was Yosutu güng Badraqu (Badai gu'n of oral tradition). The letter, while fairly incomprehensible by itself, can be related to oral tradition about Jamiyangjab's wedding. It confirms several allusive components of the oral narrative: the presence of the Mončag governor, his role as the negotiator in the name of Baruun amban's banner (still identifying itself within the Right Wing of the Altai Urianhais) and the presenting of the Nine White gifts. This document shows that in the case of Baruun ambans, the oral tradition is much more reliable and far more informative that the archive materials.

da lama kemegdegsen ö̌̈̈̌ken degü̈̈ Cülttüm kič́yenggüilen.

örisiyeltü güng noyan da mergen aq-a tan-a tümen aupulang-i juyuqu-yin

ildar-a ergün sonurdayulqu anu. Toryud-un čin wang Na-yin okin

degüï-yi man beyise-dïr boytulan uruy boluľ́aqu-yi jabdaju büküi

yabudal-i urid sonurdayulun jakiy-a bariyuluysan böged en-e tuqai

man-u yajarača tüsimed jaruju Toryud wang-un yajar-a ǒ̆uju

boytulan toytaysan tulada odu en-e qayucin jiryujan sarayin arbad-yiar 
yisün čajan belig kürgegüljü nigemösün batulqu-bar kelelčegsen en-e uday-a

kereg-tür minü bey-e nebterkeyilen uqaqu-ügei böged tus qosiyun-u

tüsimed arad-ud bitegüligdejü itegemjilen yuyuqu anu enekü alban

bičig-ün doturki boljuyan dotura

erkim aq-a noyan erkibiči bey-e-ber möriljü uralduqu sayin mori ali olan

barildaqu čoum čigeriy tabun kümü-yi abču ireged man-u yajar-a

güng Tombujab-yin bey-e kürčü irigsen büküi tula tus yurban

qosijun-u eldeb alban kereg-yi neyilen kelelčeged. daray-a yisün čajan

kürgekü kereglel-i dügügeren

erkim aq-a noyan tan-u bey-e terigülün möriljü Toryud wang-un yajar-a očiju

en-e nigen uday-a yabudal-i sayin-yiar önggerigüljü qayirilaqu-yi maju

degüü beyise noyan ba. minü bey-e bolun olan bügüdeger üneker küsejü

itegemjilen yuyumui. jiči mön ilegüü tabun sarayin qorin nigen-dür man-u

qosijun-u qayučin takiqu obu-yi takiju mori uruldaju. beki barildaju

najadam kikëi tulada egüngdür barildaqu beki. uruldaqu mori neyilegülk.ü-ber

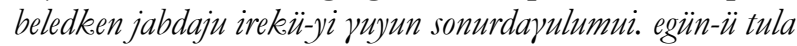

örüsiyeltü noyan erkim aq-a tan-a tümen amuyulang-i yuyuju ergübe.

jïruyan sarayin yucin-u sayin edüre. ${ }^{18}$

Little brother Čültüm called da lama, greeting diligently,

using this occasion to wish You, Gracious Lord, Wise brother, peace for ten thousand [years], I dare to communicate to You the following. I have let you know earlier through a letter that we were intending to betroth the younger sister of cin wang $\mathrm{Na}[\mathrm{mjiy}-\mathrm{a}]$ of Torguud to our beyise Jamiyangjab]. In this concern, we have sent officials to the court of Toryud wang to negotiate the betrothal. Recently in the second ten-day period of the past sixth month we have already concluded delivering the Nine White gifts and have confirmed the marriage. Because I am not well acquainted with these affairs and also our officials and commoners are ignorant, I rely on You, dear brother Lord, to please to come personally at the agreed time mentioned in the letter and bring with you as many horses good for races as you can, and five strong men [for wrestling]. Because güng Tombujab has already arrived to our place, we can discuss the affairs of our three banners together. ${ }^{19}$ And then, once we make ready the Nine White [gifts], our younger brother beyise noyan [Jamiyangjab], me and all our dependants trustfully ask You, dear brother Lord, to go first to the court of Torguud wang and to handle our affair successfully. Beside that, we kindly ask you to attend to the naadam with horse-races and wrestling on the occasion of the worship of our old banner ovoo on 21 st of the intercalary 5 th month and bring with you your wrestlers and horses.

\footnotetext{
18 MY YTA, M-170, А-1, XH-664, x. 9.

19 According to local tradition, Altai Urianhai banners used to gather at Hergiin ovoo on the bank of Tu'všin nuur, now on the boarder of Bulgan and Deluun sums.
} 
Sent with wishes of ten thousand years of peace to You, Gracious Lord and Dear Brother.

On the auspicious day of the 30 th of the 6 th month.

\section{Conclusion}

The oral narratives express how the Mongolians perceived the role of their local governors. They express open criticism and praise of the governors from the point of view of their dependant commoners, the only criterion being the welfare of the home-dwelling. Some local governors were deified (Baldandorji amban as a manifestation of Qurmusta tngri) or highly appraised as pious men acting on behalf of both religion and state (Güwe jalan, Amuүulang janggi, Čultüm da lama).

The lower nobility - representatives of the sum (sumnii zangi) - have similar importance for the local oral tradition as the banner governors. Handžav, living in Mönhhairhan, is a descendant of the clan of sumnii zangi of Oorcog sum, one of the four sums in the banner. She remembers a thorough genealogy of her ancestors, as well as many stories related to them. Another living archive of the oral tradition is Mr. Čadraabal in Bulgan sum, who is also a grandson of the banner's executive officer, Sampil zahiragč. In the Left wing banner, in the contemporary Altai sum, Čuluukaan Batnasan is a descendant of sumnii zangi Erkid yasn, and his ancestors were also famous as har bagsiz. Without these plentiful sources of oral tradition the reconstruction of the history of the Altai Urianhains in the 19th and early 20th centuries would be reduced to a one-sided interpretation at least where the archive documents are widely absent.

\section{Acknowledgements}

I would like to thank all my informants in both Hovd and Bayan-O'lgii aimags and Xinjiang with whom I had the luck to work with during my field research, especially Banzariin Handžav, Kakaanii Bekeen (Batučayan) and Zandavaanii Mažig, whose narratives are quoted in this paper. I would also like to thank Charles University in Prague, Faculty of Arts for its support of my field research within the framework of an internal grant of the Faculty of Arts (within the project "Paleografická studie a čtanka mongolskébo pisma klasickébo obdobi," 2013-2014). Then I would also like to thank Rachel Mikos for her kind and careful proofreading of the text. 


\section{References}

Abrams, L. 2010, Oral History Theory. Routledge, London and New York.

Ili-in soyol tü̈̈kïn materiyaliin mongyol ündüsüteni tusxai emkidkel, 2004. Šinčiyang-giin aradiin keblel-in xorō, Urumči.

Kebuduo shi yi 科布多事宜 1970. Fuyun deng ji 富俊等輯. Zhongguo fangzhi congshu - Sai bei difang - di 42 hao 中國方志叢書 - 塞北地方 - 第四二號. Chengwen chubanshe 成文出版社, Taibei 台北.

Vansina, J. 1985, Oral Tradition as History. The University of Wisconsin Press, Madison.

Авирмэд, Хайнзан А. 2012, Аүрвэх хөдөлгөөн ба улсыг аюулаас хамгаалах байгуумлага (1930-1934). У маанбаатар.

Бөххуяг, Ш. 2010, А^тай сайхан нутгийн ардын ухааны амин шүтэлцээ.

Redaktor Б. Бааст. У Ааанбаатар.

Бөхөө, Ц. 2007, ТҮYх бүтээлисэн ард түмэн минь. Мөнххайрхан сум.

ГанболА, М. 2006, Алтайн Урианхайн баруун гарын хошууны ноён Чүлтэм да мам (намтарт холбогдох зарим мэдээ). In: ТҮҮхийн товчоон. Tom III, Fasc. 9, s. 75-80. ХовА их сургууль ТүҮхийн тэнхим, У Ааанбаатар.

Гантулга, Ц. 2000, Алтайн Урианхайчууд. У Ааанбаатар.

Илтгэл шастир 2006. 2 sv. Еd. А. Очир, Харнууа 3. АонжиА, Ц. Төрбат.

МУИС, Монгол судлалын төв, МХСС, Эх бичиг А^тай суАлалын тэнхим, УАаанбаатар.

Катуу, Чорос Б. 2011, Монгл Урианхайн аман зохиол. У Ааанбаатар, МУ ШУАХ, Хэл зохиолын хүрээлэн.

МУЗСЭХ - Монгольн угсаатны зУйн хээрийн судалгааны эх хэрэглэгдэхүҮн (19881989) - Field reports in Mongolian ethnology (1988-1989). 2011. X. Institute of History, Mongolian Academy of Sciences - Inner Asia Studies Unit, University of Cambridge, УАаанбаатар.

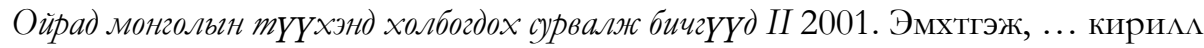
бичигт буулган, тайлбар хийсэн На. Сүхбаатар. МУИС, ТүҮхийн тэнхим, У маанбаатар.

Оюунжаргал, О. 2009, Манж Чин улсаас Монглиуудъг захирсан бодлого. Шинжлэх ухааны академи ТүҮхийн хүрээлэн, У Ааанбаатар.

Пунцагдорж, Б. - Сайнбилэг, П. 1999, Алтайн урианхайн баруун бээсийн хошууны тайлбар толь. УАаанбаатар. 
Чулуун, С. (реА.) 2011, Тувагийн түҮхэнд холбогдох архивьгн баримтыгн эмхэтгэл I. ШУА ТүҮхийн хүрээлэн, У ааанбаатар.

List of fonds related to Altai Urianhais in the National Archive of Mongolia (Монгол улсын Үндэсний төв архив, У маанбаатар):

A. Fonds of Manchu Qing period (1674-1911)

М-157: А^тай суман 24 харуул

M-160: Аөрвөдийн баруун гарын Сайн заят аймгийн чуулган даргын жасаа

М-161: А^тай Урианхайн сул амбаны тамгийн жасаа

М-162: АөрвөАийн зҮҮн гарын төгс хөлөг Аалай ханы хошуу

М-163: А^тай Урианхайн зүҮн гарын бүгдийн Ааргын жасаа

М-176: А^тай Урианхайн баруун гарын бүгдийн даргын жасаа

М-183: Манжийн үеийн баримтын цуглуулга

B. Fonds of the Autonomous Mongolia (1911-1921)

А-128: АөрвөАийн баруун гарын Үнэн зоригт хан аймгийн чуулган даргын жасаа

А-130: Аөрвөдийн баруун гарын А^тай Урианхайн Ёст засгийн хошуу

А-134: А^тайн Урианхайн баруун гарын зүҮн хошуу

А-135: Аамбийжанцангийн хувийн ба шавь хошууны тухай цуглуулга

А-141: Баруун хязгаарыг илбэн тохинуулах сайА

А-144: ХовАод сууж хэрэг шийтгэгч сайА

А-146: Баруун хязгаарыг байцаан Үзэж, сэргийлэн батлах сайА

C. Fonds of the Mongolian People's Republic (1921 - today; in the case of Altai Urianhais mainly up to 1927)

Ф-62: А^тай урианхайн Ёст засгийн хошуу

Ф-168: А^тай урианхайн Чуулган дарга

Ф-169: АөрвөАийн Баруун гарын аймаг

Ф-170: Аөрвөдийн ЗҮҮн гарын аймаг 
Ф-171: Ховдын сайА

Ф-261: А^тай урианхайн Итгэмжит засгийн хошуу

Ф-263: А^тай урианхайн Зүтгэлт засгийн хошуу

Ф-264: А^тайн урианхайн Эетэй засгийн хошуу

Ф-265: А^тайн урианхайн Зоригт засгийн хошуу

Ф-266: А^тайн урианхайн Аархан бэйсийн хошуу

Ф-267: А^тайн урианхайн Сартуул засгийн хошуу

Ф-268: Ховдын сайАын харъяа Хасгийн хошуу 


\title{
Cornelius Rahmn - pioneer of Kalmuck linguistics
}

\author{
Jan-Olof Svantesson (Centre of Languages and Literature, Lund University)
}

\section{Mongolian studies in Sweden}

Although there is no academic tradition for Mongolian studies in Sweden, some individuals have from time to time made noteworthy contributions to this field. Best known among these is no doubt Philip Johan Stralenberg (1677-1747), whose famous description of Northern and Eastern Eurasia from 1730 contains a rather extensive Kalmuck wordlist (see also Krueger 1975a). Stralenberg was born in Stralsund, at that time belonging to Sweden, and became an officer in the army of the Swedish king Charles XII, who was defeated by Peter I of Russia at Poltava in 1709. Like many other Swedish officers he was captured and sent to Tobolsk in Siberia, where he collected materials about Siberian geography and languages. He was allowed to return to Sweden in 1722, and published his book in Stockholm in 1730. He spent his last years at his brother's castle Fröllinge in the small southern Swedish village of Getinge - incidentally the same village where I grew up in the 1940s and 50s without knowing anything about Stralenberg.

Another Swedish prisoner of war who made a notable contribution to Kalmuck studies was Johan Gustaf Renat (1682-1744), who was captured first by the Russians at Poltava and later by the Dzungars, and spent 17 years in Dzungaria. When he could return to Sweden in 1734, he brought home two maps, the first detailed maps of the Oirad area in Central Asia, now held by Uppsala University Library (see Poppe 1955).

Although rather many Swedish missionaries were working in Mongolia during the first half of the 20th century, only one of them, Folke Boberg (1896-1987), 


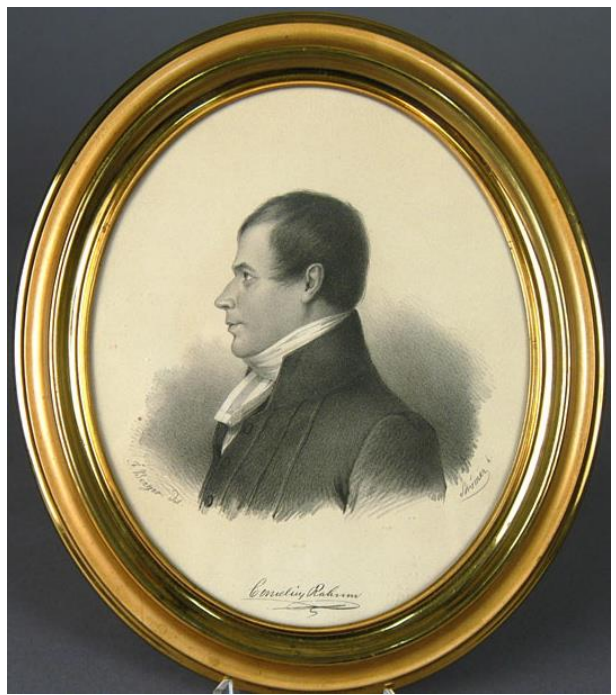

Figure 1: Cornelius Rahmn (by courtesy of Göteborgs stadsmuseum)

who was a missionary in Inner Mongolia from 1922 to 1951 worked on the language. He published a textbook of Mongolian in 1946 and a Mongolian-English dictionary in three volumes in 1954.

\section{Cornelius Rahmn}

In my opinion, an earlier missionary, in fact the first Swedish missionary to Asia, Cornelius Rahmn (Figure 1), was the one who made the most valuable contribution to Mongolian language studies. He is the author of a short Kalmuck grammar and a fairly large Kalmuck-Swedish dictionary, most probably written while he was a missionary among the Kalmucks for four years, from 1819 to 1823 . Since these works until recently existed only in manuscript form they remained unknown to most scholars in the field (although they are mentioned by Bawden 1985:283). Rahmn's grammar and dictionary were translated into English and published by me in 2009 and 2012; cf. also Svantesson (2009b).

Here I will first give a brief account of Rahmn's life, based on Jansson (1951), on Bawden (1985) and on Rahmn's daughter Hanna's biography of her father (Brusewitz 1893). The son of an artillery officer, Cornelius Rahmn was born in 1785 in Göteborg (Gothenburg), Sweden's second-largest city. He studied law at Lund University but never practised it. Instead he pursued an ecclesiastical career, becoming a chaplain with the Götaland Artillery Regiment in 1810. John Paterson, a member of the London Missionary Society who lived in Sweden for some years after 1807, made Rahmn's acquaintance, and in 1817 Rahmn was recruited to open the Society's mission for the Buriads at Irkutsk in Siberia together with the English missionary Edward Stallybrass (1794-1884). 
On their way to Irkutsk, the two missionaries first spent some time in Saint Petersburg before leaving in December 1817 for Moscow, where they were received by Emperor Alexander I, who showed a sympathetic interest in their mission. On 19 January 1818 they left Moscow by sleigh together with their respective wives, Elizabeth (Betty) Rahmn and Sarah Stallybrass, both pregnant, and the Rahmns's daughter Hanna, who was only two years old. After a two-month journey they arrived at Irkutsk on 16 March 1818.

Because of his wife's poor health, Rahmn and his family had to leave Irkutsk as early as May 1819. They moved to Sarepta to work among the Kalmucks. Sarepta had been founded as a kind of Christian colony by the Moravian United Brethren (or 'Herrnhutians') in 1765. It is situated to the south of Tsaritsyn (later Stalingrad and now Volgograd), where the small Sarpa river flows into the Volga. Today it is part of Krasnoarmeysk, a southern suburb of Volgograd. Rahmn stayed there for four years, still working for the London Missionary Society despite living among the Moravian Brethren. In June 1823 the Russian authorities forced him to cease his missionary activities, at which point he moved to Saint Petersburg. He stayed there until 1826, when he became an international secretary at the headquarters of the London Missionary Society. In 1832 he became pastor of the Swedish congregation in London, and in 1841 he returned to Sweden to take over the small rural parish of Kalv (then written 'Kalf') in southwest Sweden, where he remained pastor and dean until his death in 1853.

During his stay among the Kalmucks, Rahmn started to translate the Bible into Kalmuck because he was dissatisfied with the existing translations made by Isaac Jacob Schmidt (1779-1847), who belonged to the church of the Moravian Brethren. The extent of Rahmn's translations and their whereabouts are not known; they may have been lost when some of Rahmn's letters and other documents were burned after his death (Bawden 1985:282-3). It may be that the dictionary and grammar were written in preparation for the Bible translation. In addition to Swedish, Rahmn knew at least German and English (his wife Betty was Scottish), and like other Swedish clergymen at that time he had studied Latin, Classical Greek and Biblical Hebrew. He was thus well prepared for carrying out his linguistic work and for translating the Bible.

\section{The Kalmucks and their language}

The Kalmucks are Western Mongols (Oirads) who came from western Mongolia and northwestern China to Russia in the 1630s and settled in the lower Volga area, to the north and northwest of the Caspian Sea. Many of them returned to China and Mongolia in 1771. The name 'Kalmuck' is normally used of those living in Russia (and of those who were in Russia but returned to China or Mongolia), while 'Oirad' is used of those living in China and Mongolia. Although Kalmuck and Oirad are sometimes described as different languages, they are basically the same. 
Rahmn calls the people and the language 'Kalmuck' (or sometimes 'Mongolian'), never 'Oirad'; the latter term is in fact not even listed in his dictionary.

The Oirads originally used the Old Mongolian script, but in 1648, an Oirad (or Kalmuck) script was created by Zaya Pandita (1599-1662), who modified the Mongolian script to make it reflect the spoken language better (see e. g. Kara 2005). Unlike the Old Mongolian script, which does not distinguish $/ \mathrm{t} / \sim / \mathrm{d} /$, /o/ $\sim / \mathrm{u} /$ and $/ \varnothing / \sim / \mathrm{y} /$, the Oirad script is more or less phonematic. Also called the Clear script (todo bicig), it is still used to some extent by the Oirads in China although its use is discouraged by the Chinese authorities, who, preferring to regard Oirad as a dialect of Mongolian, promote the Mongolian script and a language standard based on the Chahar dialect. Similarly, Oirad is regarded as a dialect of Mongolian proper in Mongolia, where standard Halh Mongolian written in the Cyrillic alphabet is the only widely used written language. The Cyrillic alphabet has replaced the old script among the Kalmucks living in Russia as well, but the written language used by them is based on the Kalmuck/Oirad language, rather than on Mongolian. However, the great majority of Kalmucks living in Russia do not speak or write Kalmuck any more, using only Russian.

\section{Rahmn's Kalmuck manuscripts}

Three manuscripts by Rahmn which deal with the Kalmuck language, numbered R162, R163 and R164, are held by Uppsala University Library. There is also a fourth manuscript (R165), written in Classical Mongolian.

Manuscript R162 is a Kalmuck-Swedish dictionary, written on light-blue paper, $18 \times 22 \mathrm{~cm}$. The text on the cover page reads: Författaren till detta KalmuckisktSvenska lexicon är prosten $i$ Kalf (Göteb.) stift Cornelius Rahmn bvilken 1817-25 verkade som missionär $i$ Wolgatrakterne, Inköpt 26/4 1889 af Rahmns änka [The author of this Kalmuck-Swedish dictionary is the Dean of Kalf (Diocese of Göteborg), Cornelius Rahmn, who in 1817-1825 was a missionary in the Volga region. Bought on 26 April 1889 from Rahmn's widow]. There is no title page and no foreword or other explanation from the author. The manuscript consists of 281 numbered pages, two empty pages, and a final page, number 284, which has the heading Förtekning på ord, hwilka $i$ brist af fullt motswarande $i$ kallmuckiskan, öfwersättas med phraser el. composita [List of words which, lacking a perfect correspondence in Kalmuck, are translated by phrases or compounds] and contains translations of some Swedish words into Kalmuck. The main part of the dictionary contains more than 7,000 Kalmuck words, written in the old Kalmuck alphabet, each with a Swedish translation. Most words have a German translation as well, written in old German 'blackletter' handwriting (Kurrentschrift), corresponding to printed Fraktur style. It is usually less detailed than the Swedish one. Each page is divided into two parts by a vertical line. In the wider left-hand part of the page, the words are arranged alphabetically according to the Kalmuck script. The right-hand part contains additional 
words or examples, usually derived from or otherwise related to those on the left, or at least belonging in the same alphabetical section (see Figure 2).

Manuscript R163 is a Swedish-Kalmuck wordlist. It has no cover page; the number R163 and the text Corn. Rabmn. Svensket Kalmuckiskt lexicon inköpt 26/4 1889 till Ups. Univ. Bibl. [Corn. Rahmn. Swedish Kalmuck dictionary bought on 26 April 1889 for Uppsala University Library] is written on its first page. The paper is lightgrey (first half) and light-blue, $22 \times 34 \mathrm{~cm}$. The manuscript consists of 129 written but unpaginated pages (and 33 empty pages interspersed between them). Most pages are divided into three columns, with each column containing Swedish words beginning with certain letter combinations (e. g. 'Ab', 'Ac') and their Kalmuck translations. Within each column the words are roughly in Kalmuck alphabetical order, indicating that Rahmn most probably compiled this wordlist by going through his Kalmuck-Swedish dictionary from beginning to end and writing down each word pair in the relevant column. Thus it is basically an index to the Kalmuck-Swedish dictionary. Sometimes the Swedish translation is slightly different from that given in the Kalmuck-Swedish dictionary, and there are also a few additional words not found in that dictionary.

Manuscript R164 is a Kalmuck grammar, written on light-blue paper, $18 \times 22$ $\mathrm{cm}$. The text on the cover page is: Corn. Rahmn, Kalmuckisk grammatika, köpt till Ups. U.B. 26/4 1889 [Corn. Rahmn, Kalmuck grammar, bought for Uppsala University Library 26 April 1889]. The manuscript contains two versions of the grammar. The first version has the heading Kalmuckisk grammatik [Kalmuck grammar] and consists of 37 unpaginated pages. The second version has the heading Anmärkningar hörande till kalmuckiska spraikets grammatik [Remarks belonging to the grammar of the Kalmuck language] and consists of only 14 unpaginated pages. There are two additional pages listing adverbs with Swedish translations, two pages of mono- and disyllabic words in Kalmuck only, one page containg The Lord's Prayer (after Schmidt) with interlinear Swedish translation, one page of Kalmuck words written syllable by syllable and one page showing the Kalmuck digits. The first version of the grammar is more complete and the information seems more accurate there than in the second version. My impression is that the second version is a sketch written before the first and more final version. Inspection of the manuscript shows that the two versions originally were two different manuscripts bound together, most probably in the wrong order.

The fourth manuscript, R165, is also written on light blue paper, $22 \times 36 \mathrm{~cm}$. The text Köpt 26/4 1889 af prosten Corn. Rabmns änka [Bought 26/4 1889 from Dean Corn. Rahmn's widow] is written on it. It consists of 142 pages written in Old Mongolian script. On the inside of the cover, Rahmn has written Cornelius Rabmn Irkutsk 1819, and 1 Tempadb [1st notebook] is written in Russian on top of the first page. My impression is that Rahmn wrote this manuscript while he was learning Classical Mongolian, probably before he moved from Irkutsk to Sarepta. 


\section{Rahmn's dictionary}

The dictionary is fairly large, containing more than 7,000 words and many example sentences. As mentioned above, the main part of the dictionary is written on the left-hand side of each page, ordered approximately in Kalmuck alphabetical order, but quite many words, written on the right-hand side of the pages, seem to have been added after the main part was written. Many of these are derived words, such as passive and causative verbs.

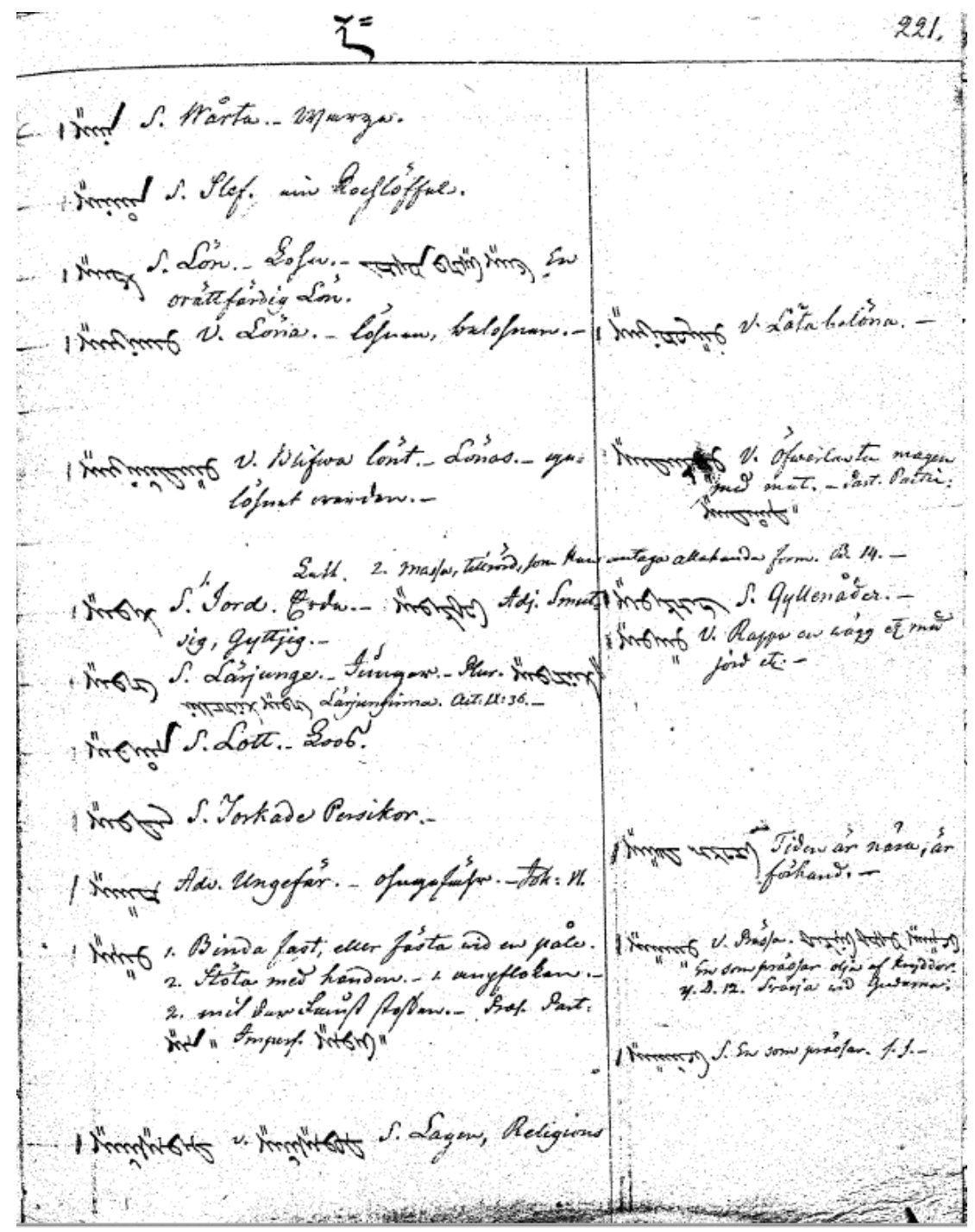

Figure 2: A page from Rahmn's dictionary 
In addition to simple, derived and compound Kalmuck words, Rahmn gives many phrase and sentence examples, usually with Swedish - but not German - translation. A few lack translation altogether. Many of the examples include a reference to the text they are taken from. The most frequently cited texts are the Bible and some Buddhist Kalmuck texts, in particular the Yligerijin dalai but also Bodhimör and a few others. The only Kalmuck Bible translations existing at that time were those by Isaac Jacob Schmidt. According to Bawden (1985:110, 281), Schmidt published the Gospel according to Saint Matthew in 1815 and the three remaining Gospels and the Acts of the Apostles in 1821, all printed in Saint Petersburg. These are indeed the only books of the Bible that Rahmn refers to. I suppose that Rahmn generally cites Schmidt, but since I have not had access to Schmidt's Bible translations, I cannot exclude the possibility that some of the Bible citations are Rahmn's own proposed translations. In a few places, Rahmn refers explicitly to Schmidt's translations, apparently to point out that he is not himself responsible for the information given, or to criticize a translation.

For most words, the word class is indicated. Rahmn often gives inflected forms of nouns and verbs; most often the genitive and the plural for nouns, and participles for verbs. They are often accompanied by a reference to the source they are taken from; the sources used are the same as for the sentence examples. Rahmn also gives encyclopaedic information in some of the entries in the dictionary, often referring to 'Pallas', i. e. Sammlungen historischer Nacbrichten wiber die mongolischen Völkerschaften (1776/1801) by Peter Simon Pallas (1741-1811).

Rahmn does not tell anywhere in his manuscripts how he worked with his dictionary and grammar. It is rather clear that he wrote the Kalmuck words himself, but he does not tell how he learned the script. It would have been interesting to know if he always learned the spelling from a Kalmuck teacher, or if he sometimes listened to spoken words and wrote down what he heard. There is quite a lot of variation in the spelling, but if this comes from Rahmn or from his informants is not easy to tell (and perhaps not very important). My impression is that Rahmn must have elicited some information systematically from informants, in particular derived verbs. As mentioned above, there are many derived verbs in the dictionary, and I know from personal experience that it is very unlikely that so many would be encountered in speech or texts.

\section{Rahmn's grammar}

Rahmn's grammar is written in Swedish, and Kalmuck words are given in the Kalmuck Clear script. Here I will describe the first, more complete version of the grammar. It consists of two parts, called Ortographie [Orthography] and Etymologie [Etymology]. The first part is only slightly more than two pages and gives a list of the Kalmuck letters, and of all combinations of a consonant and a vowel, in Kalmuck script and transcribed with the Roman alphabet (see Figure 3). 


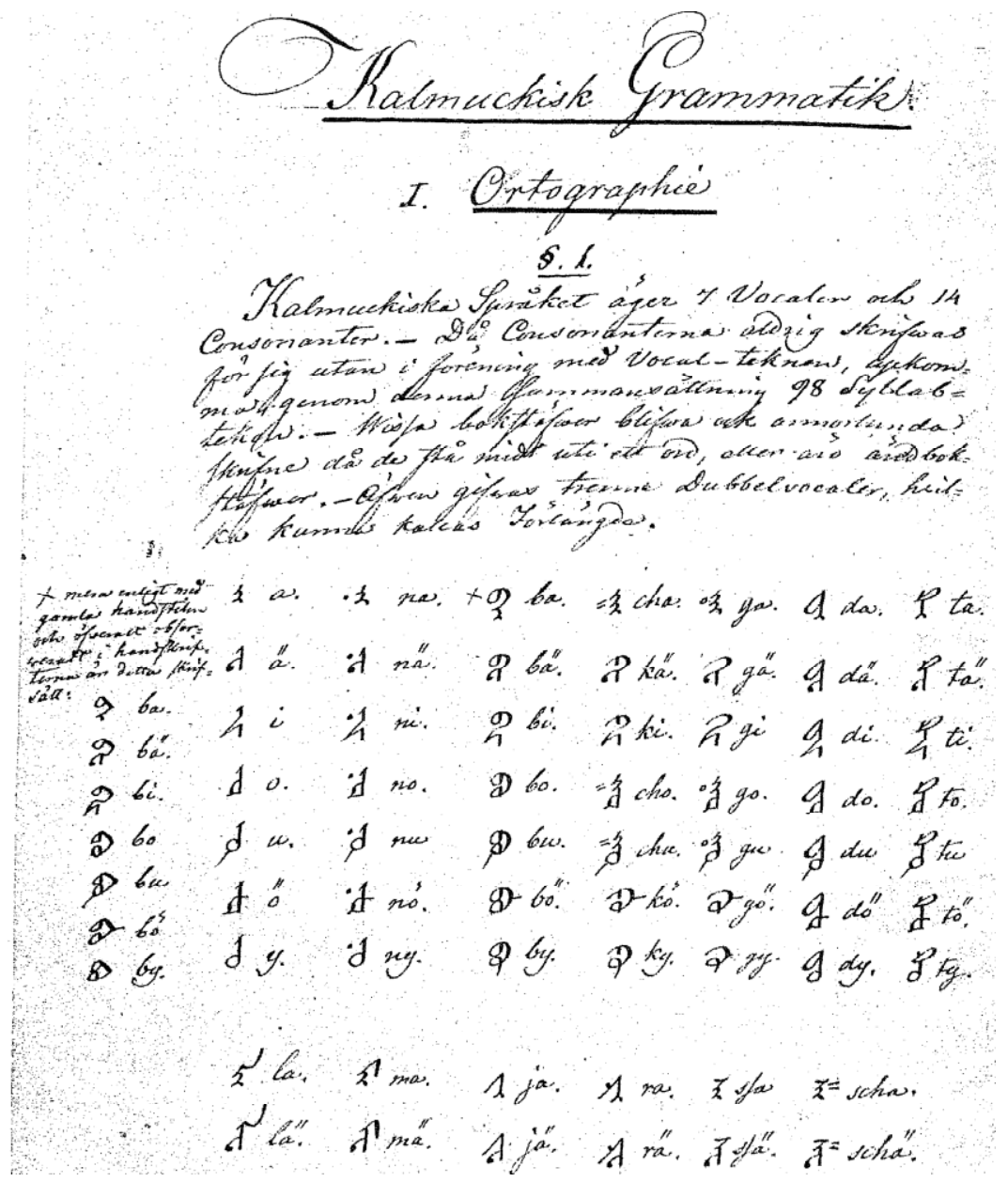

Figure 3: The first page of the grammar

The second, 'etymology', part takes up the remaining 35 pages. As in other grammars from this time, the word etymology refers to word structure and inflection, i. e. to what is now termed morphology. It deals with nouns, adjectives, numerals, pronouns, question words and verbs and basically consists of inflection tables. Like other European grammarians of that time, Rahmn took the grammar of wellknown European languages, especially Latin, as a pattern, but there are not so many signs that Rahmn pressed the language into a Latin form. An obvious case of this, however, is his recognition of the vocative as a separate case, for which there is no support in Kalmuck. Another characteristic of grammatical descriptions of the time is the almost complete negligence of syntax. Even major and conspicuously different features of the syntax, like the verb-final (SOV) word order in Kalmuck, were not considered worth mentioning in a grammar. 


\section{Phonology}

In this and the following sections I will give an account for the linguistic information that can be culled from Rahmn's dictionary and grammar. For the historical development I compare with Doerfer (1965), who has collected Western European texts from 1692 to 1827 which contain Kalmuck words written with the Latin or Cyrillic alphabet, and on pp. 17-24 he gives a short overview of what these sources tell about the historical development of Kalmuck.

\subsection{Kalmuck script and pronunciation}

Rahmn writes the Kalmuck words with the old Kalmuck alphabet (the 'Clear script'). It is transliterated here with letters of the Latin alphabet printed in boldface. There is no discussion of the pronunciation in Rahmn's works, except that a transcription in the Latin alphabet is given in the table of the Kalmuck alphabet included in his grammar (Figure 3). For a few words in the dictionary, an indication of the pronunciation is given as well, presumably for words where Rahmn thought that the pronunciation was very different from the written form (in most cases due to reductions). It is obvious that he intends the letters of the Latin alphabet to be pronounced as in German, which is natural because Rahmn was working among the German-speaking Moravian Brethren. Rahmn romanizes the vowels as $a, \ddot{a}, i, o, u, \ddot{o}, y$, i. e. IPA [a, $\varepsilon, \mathrm{i}, \mathrm{o}, \mathrm{u}, \varnothing, \mathrm{y}]$ (transliterated by me as a, e, i, o, $\mathbf{u}, \boldsymbol{\emptyset}, \mathbf{y})$. Most consonants are transcribed in the expected way by Rahmn. The sibilants and affricates are given as $s s, s c h, s$, z, i. e. [s, $\left.\int, z, t s\right]$ (transliterated by me as $\mathbf{s}$, $\check{\mathbf{s}}, \mathbf{z}, \mathbf{c})$. In addition to the standard letters of the Kalmuck alphabet, Rahmn uses a number of galig letters in foreign words, usually Buddhist terms of Indic origin, but also some modern loans from Russian.

The letters $\mathbf{u}$ and $\mathbf{y}$ differ only by $\mathbf{u}$ having an extra stroke (see Figure 3), and Rahmn follows the usual orthographic convention of writing the sound $[\mathrm{u}]$ with the letter $\mathbf{y}$ (i. e. without the stroke) in contexts where the pronunciation [y] is impossible. I transliterate $[\mathrm{u}]$ written in this way as $\mathbf{u}$.

\subsection{Long vowels and diphthongs}

Vowel length, which is phonemic in Kalmuck, is indicated with a small diacritic stroke, which I transliterate here with a macron over the vowel $(\overline{\mathbf{a}}, \overline{\mathbf{e}}, \overline{\mathbf{i}}, \overline{\mathbf{o}}, \overline{\mathbf{u}}, \overline{\mathbf{g}}, \overline{\mathbf{y}})$. Rahmn calls the length mark an accent. He probably heard long Kalmuck vowels as stressed (or accented) since long Swedish vowels are always stressed. In the modern Oirad script, this length mark cannot be attached to u or y (Jamca 1999:14), but Rahmn sometimes does so (though not very frequently).

Rahmn says that the combinations uụ, yy and ou are lengthened 'double vowels' and romanizes them as $u h, y h$, ob in his grammar, presumably meaning [u:], [y:], [o:]; he does not mention the combination oy although it occurs frequently (in 
more than 400 words) in the dictionary. Rahmn also says that lengthened vowels cannot combine with the 'accent' (length mark).

One of the earliest published grammars of Kalmuck, Bobrovnikov (1849), contains a rather extensive and, as far as I can judge, reliable section on pronunciation. Bobrovnikov says (pp. 18-19) that $\mathbf{y y}$ and ou are alternative spellings of $\mathbf{y}$ and uu, respectively, and that they are pronounced [y:] and [u:]. The combinations øy and ou are usually the reflexes of Old Mongolian $*_{e h y}$ and $* a b u$, respectively (as reconstructed by Svantesson et al. 2005), and were probably diphthongs at the time when the Kalmuck script was created (see e. g. Krueger 1975b). In Modern Kalmuck they have been monophthongized to [y:] and [u:]. The modern standard of the Kalmuck (Oirad) script used in China, as given by Jamca (1999), writes these vowels as yy and uu, and the combinations $ø \mathbf{y}$ and ou are not used.

It is difficult to know whether Rahmn's transcription of oụ as ob really means [o:] (as against Bobrovnikov's 'long u', [u:]). Since Rahmn uses the German, and not Swedish, sound values of the Latin letters in his table of the alphabet, and since $h$ can indicate vowel length in German, but not in Swedish, the most probable interpretation is that his $o b$ does mean [o:] as in German. However, the letter $o$ is ambiguous between the pronunciations [o:] (as in son [so:n] 'son') and [u:] (as in ko [ku:] 'cow') in modern Swedish, so he might also have meant [u:], a suggestion that is supported by the fact that there is rather frequent variation between ou and uu in Rahmn's dictionary. A third possibility is that Rahmn's ob denotes the vowel [v:], of a quality between [u:] and [o:], ocurring in some Swedish dialects, mainly in words such as son 'son', that are written with the letter $o$ and pronounced [o:] in modern standard Swedish. In Rahmn's time, Swedish spelling was not completely standardized, and the spelling ob was used for this sound by some writers (Teleman 2002:137).

The different spellings and pronunciations are compared in (1), where ' denotes Rahmn's 'accent'. The pronunciation given under 'Spelling' is the probable pronunciation at the time when the Clear script was created.

\begin{tabular}{|c|c|c|}
\hline $\begin{array}{l}\text { Spelling } \\
\text { uụ [u:] }\end{array}$ & $\begin{array}{l}\text { Rabmn } \\
\text { [u:] }\end{array}$ & $\begin{array}{l}\text { Bobrovnikov } \\
\text { [u:] }\end{array}$ \\
\hline$\overline{\mathbf{u}}-$ & ['u] & - \\
\hline $\mathbf{y y}[\mathrm{y}:]$ & [y:] & [y:] \\
\hline$\overline{\mathbf{y}}-$ & ['y] & - \\
\hline oụ $[\mathrm{ou}]$ & {$[\mathrm{o}:] \sim[\mathrm{u}:] \sim[\mathrm{v}:] ?$} & [u:] \\
\hline$\overline{\mathbf{o}} \quad[\mathrm{O}:]$ & ['o] & [o:] \\
\hline бу [øу] & ? & [y:] \\
\hline $\begin{array}{lll}\overline{\boldsymbol{\varnothing}} & {[\varnothing:]}\end{array}$ & ['ø] & [ø: \\
\hline
\end{tabular}

Doerfer dates the monophthongization of diphthongs to the second half of the 19th century, and if this is correct, it should not be reflected in Rahmn's data. Even if they are not very clear, Rahmn's descriptions and the fact that there is frequent variation between oụ and $\mathbf{u u}$, as well as between $\mathbf{ø y}$ and $\mathbf{y y}$, in his dictionary, sug- 
gest, however, that monophthongization was an ongoing process when he wrote his works. Furthermore Bobrovnikov's description shows that the process was already completed when he wrote his grammar in 1849.

\subsection{Vowel harmony}

The distribution of vowels (and of some of the consonants) is governed by vowel harmony, which requires that a Kalmuck word must contain only back vowels (a, $\mathbf{o}, \mathbf{u})$ or only front vowels $(\mathbf{i}, \mathbf{e}, \mathbf{y}, \mathbf{o})$. Vowels from different classes cannot co-occur in the same word, except for the 'neutral' i, which can occur in back-vocalic words although it is a phonetically front vowel. In traditional Mongolian grammar, back and front vowels are called 'male' and 'female' vowels, respectively, but Rahmn does not use these terms. He was apparently unaware of vowel harmony, which he never mentions, and his Kalmuck spellings violate vowel harmony quite often. For example, although he usually complies with the rule that the 'infinitive' suffixes xu and ky should be attached to back-vocalic and front-vocalic verbs, respectively, this is far from always the case. The same is true for other suffixes. In the dictionary, Rahmn does mention one rule related to vowel harmony, in the entry for the concessive particle bēsu, where he states (in translation): 'combined with verbs ending in ky it is written bēsu, but with those in $\mathbf{x u}$ it is written bāsu'. There is a similar passage in the grammar, about the 'fourth gerund' marker lāran/leren: "when a verb in infinitive ends in xụ, this gerund is lāran, but if the verb ends in ky, the gerund is leren."

Rahmn's table of combinations of a consonant and a vowel shows that the letter $\mathbf{x}$ (which he transcribes $c h$ ) occurs only before the (back) vowels $\mathbf{a}, \mathbf{o}$, $\mathbf{u}$, while $\mathbf{k}$ occurs only before the (front) vowels $\mathbf{e}, \mathbf{i}, \mathbf{\sigma}, \mathbf{y}$, and also that $\mathbf{g}$ is written in different ways in these positions (reflecting allophonic variation).

\subsection{Vowel reduction}

In modern Kalmuck, originally short vowels in non-initial position are reduced to non-phonemic schwas or even completely deleted (see e. g. Svantesson et al. 2005:186), and the schwas are not written in the Cyrillic Kalmuck orthography. According to Doerfer, reduction of non-initial vowels does not take place until the second half of the 19th century, and should thus not be reflected in Rahmn's material. There is, however, a great deal of variation in the spelling of non-initial short vowels in Rahmn's dictionary, suggesting that vowel reduction was already taking place at his time. This is in fact the most common source of spelling variation in the dictionary; a few examples are: abxoi $\sim$ abxui 'capital', ajiga $\sim$ ajaga 'drinking vessel', amisxal $\sim$ amisxul 'breath', kyryl $\sim$ kyrel 'metal', tabtai $\sim$ tabtei 'well'. It can be mentioned that all non-reduced vowels of (at least modern) Kalmuck occur in Swedish as well, although with slightly different pronunciations in some cases, so Rahmn should have had no difficulty distinguishing them. 


\subsection{Palatalization}

According to Doerfer, fronting of [a] to [ $\varepsilon$ ], conditioned by [i] in the next syllable, took place during the first part of the 19th century, i. e. at the time when Rahmn was among the Kalmucks, but the corresponding fronting of [o] to [ø] took place later. These changes are usually not reflcted in Rahmn's material, but this may just mean that he follows the spelling norm, although there are at least two cases of variation that might indicate ongoing fronting: šabi $\sim$ šebi 'pupil' and oški $\sim$ øški 'lung'.

In the modern variant of the Clear script, two new letters, denoting [t $]$ and [d] , have been introduced. These sounds were originally palatalized variants of $\mathbf{c}$ [ts] and $\mathbf{z}[\mathrm{z}]$ before $\mathbf{i}$, which became phonemic at some point in the historical development of Kalmuck. There is no indication in Rahmn's material that $\mathbf{c}$ and $\mathbf{z}$ are palatalized before $\mathbf{i}$; in the table of syllables in his grammar, Rahmn transcribes the combinations ci and zi as $z i$ and si, i. e. [tsi] and [zi], respectively.

\subsection{Morphology}

For most words in the dictionary, the word class is indicated. As regards the verbs, which are always given in the 'infintive' form, ending in $\mathbf{x y}$ or $\mathbf{k y}$, this is unproblematic, but it is obvious that Rahmn had some difficulties with nouns and adjectives, which, as is well known, are less clearly distinguished in Mongolic languages than in many European languages. It is often clear from the manuscript that Rahmn has changed the labelling and translation from an adjective to a noun, or the other way round.

In his grammar, Rahmn recognizes eight cases for the nouns: nominative, genitive, dative, accusative, vocative, two different instrumentals, and ablative. He remarks that the vocative is always identical to the nominative. Rahmn says that first instrumental is formed with jēr/bēr meaning 'through'. Second instrumental is formed with the particle lyge (in everyday language contracted to lēe) or more often with tēgan (contracted to tei) meaning 'together with'. His second instrumental thus corresponds to what is now usually called comitative. The accusative has three different forms according to Rahmn, with the suffixes -i (or zero), -ijigi or -bēn. The last form, in modern grammars described as a reflexive, occurs only in the singular, he says, but no differences in meaning are mentioned. He recognizes five declensions for the nouns, depending on their final letters. For the adjectives, Rahmn notes that many are derived from nouns by the suffix -tei (-tai, -tu). He also notes the intensification of adjectives by a reduplicative prefix, as in xabxara 'pitch black' (from xara 'black').

The dictionary contains many derived words, in particular passive and causative verbs. It is interesting to note that Rahmn lacks a terminology for the derived verbs, except for the passive, a category that is well-known in European languages. In particular, he has no term for 'causative', a category usually not found in Euro- 
pean languages but very common in Kalmuck. About 750 derived causative verbs are recorded in the dictionary, but only around 240 passives.

\subsection{Verb morphology}

In the section on verbs in his grammar, Rahmn gives conjugation tables for two verbs, which he regards as auxiliaries, bajixu 'to be' and bolxụ 'to become', and exemplifies the conjugation of other verbs with abxy 'to take'. He says that the verb has been investigated only incompletely. This can be seen also by comparing the two different versions of the grammar which basically agree in the sections on nouns and pronouns, but for the verbs, the terminology and the number of categories differ substantially between the two versions, and both sometimes differ from the terminology used in his dictionary.

One interesting point is subject agreement in the verb forms. As is well known, some Mongolic languages, such as Buriad and Kalmuck, but not Mongolian proper, have developed subject agreement suffixes on verbs, by cliticizing personal pronouns. In modern Kalmuck, this is obligatory, but Birtalan (2003:225) says that "The personal endings are only marginally attested in Written Oirat, indicating that they are a relatively recent innovation." Rahmn's tables of verb conjugation confirm this and show an intermediate picture. In his tables, the monosyllabic personal pronouns (first person singular bi ' $\mathrm{I}$ ', second person singular ci 'you' and second person plural ta ' $y o u$ ') are often suffixed to the verb but the disyllabic first person plural (bida 'we') is almost never suffixed. Thus a commonly occurring pattern is the one used e. g. for Rahmn's 'second perfect':

$$
\begin{aligned}
& \text { abalai bi } \\
& \text { ci abalai ci } \\
& \text { abalai } \\
& \text { bida abalai } \\
& \text { ta abalai ta } \\
& \text { ede abalai }
\end{aligned}
$$

'I have taken many times'

'you have taken many times'

'he has taken many times'

'we have taken many times'

'you have taken many times'

'they have taken many times'

In Rahmn's conjugation tables, as in Written Oirad in general, the pronoun following the verb is usually written as a separate word and should perhaps be regarded as cliticized rather than suffixed. When agreement suffixes (or cliticized pronouns) occur in Rahmn's verb conjugation tables, he usually conforms to the pattern in (2) (including the absence of first person singular bi in subject position). The only common alternative is to have the pronoun in subject position only, as in Rahmn's 'second present' (3). This alternative occurs in some of the tables in the final version of the grammar and in almost all conjugation tables in the preliminary version.

(3)

$$
\begin{aligned}
& \text { bi abdag } \\
& \text { ci abdag } \\
& \text { abdag } \\
& \text { bida abdag }
\end{aligned}
$$

'I usually take'

'you usually take'

'he useually take'

'we usually take' 


\section{ta abdag \\ 'you usually take' \\ ede abdag \\ 'they usually take'}

Thus, subject agreement is not as widespread in Rahmn's material as it is in modern Kalmuck, where it is obligatory for first and second person (including second person plural). For example, the modern Kalmuck verb forms corresponding to those in (2) and (3) are (Tamara Esenova, pers. comm.):

(4) Modern Kalmuck agreement suffixes

\begin{tabular}{|c|c|c|c|}
\hline 1 pers. & sing. & $a w-l \varepsilon-w$ & $a w-d-w$ \\
\hline & plur. & aw-le-č & aw-d-čc \\
\hline 2 pers. & sing. & aw-le-wdn & aw-d-wdn \\
\hline 3 pers. & plur. & $\begin{array}{l}\text { aw-le-t } \\
\text { aw-le }\end{array}$ & $\begin{array}{l}\text { aw-d-t } \\
\text { aw-dg }\end{array}$ \\
\hline
\end{tabular}

The question why agreement suffixes developed in Oirad/Kalmuck and Buriad but not in Mongolian proper has no definite answer. Although standard Halh Mongolian is strictly verb-final, a personal pronoun can be inserted after the sentencefinal verb in colloquial speech, as an afterthought, but not as a suffix. Personal pronouns in this position are also found in the Secret History of the Mongols, the oldest narrative text in any Mongolic language (13th century). Perhaps this use of personal pronouns has been generalized and subsequently grammaticalized under the influence of neighbouring Turkic languages, where this is the general pattern.

A question dealt with by Doerfer (1965) is the loss of $\mathbf{g}$ in the perfect participle suffix gsan/gsen, which, according to Doerfer's material, took place during the 18th century, i. e. before Rahmn's manuscripts were written. Rahmn always writes $\mathbf{g}$ here, but this probably just means that he adheres to the spelling norm; he does not tell whether or not this $\mathbf{g}$ is pronounced.

\section{Relation to other Western works on Kalmuck}

Rahmn's dictionary is earlier than the published dictionaries in European languages and contains a relatively large number of words. It is interesting to compare it with the Kalmuck-German dictionary compiled by the German missionary Heinrich August Zwick (1796-1855) and published in 1852. Zwick belonged to the Moravian Brethren and was living at Sarepta while Rahmn was there. Rahmn's and Zwick's dictionaries are about the same size. I have not compared them in detail, but there are some obvious similarities, such as the great number of derived verbs in both of them. Comparison of Rahmn's dictionary with Krueger's dictionary of written Kalmuck (1978/1984) shows that there are quite a few words which are found both in Rahmn's and Zwick's dictionaries, but not in other dictionaries or texts. Krueger compiled his dictionary from published and unpublished texts and also included words from Zwick's dictionary (and from other dictionaries), but he did not have access to Rahmn's manuscripts. For some words, Zwick's dictionary 
is Krueger's only source, and about one-third of those words are found in Rahmn's manuscript as well, according to a word count I made of a section of the dictionaries. Krueger (1973:68) also says that "it appears that he [Zwick] relied heavily on the Bible translations and on some works such as the Üliger-ïn dalai in Kalmyk". Unlike Rahmn, Zwick gives no references to his sources, but the ones mentioned by Krueger are exactly the ones that Rahmn refers to most often.

One might ask whether Rahmn had any dictionary material from the German missionaries at his disposal. The existence of some spelling and grammatical mistakes in Rahmn's German glosses suggests that he did not. Zwick often gives exactly the same German gloss as Rahmn (with any mistakes corrected). There is also another, rather curious fact suggesting that Zwick had access to Rahmn's material when he wrote his dictionary. This concerns the word šabarin, translated as gyllenåder by Rahmn (see Figure 2). This word, literally meaning 'golden vein', is unknown in modern Swedish, but according to the historical dictionary of the Swedish Academy (Svenska Akademien 1893-) it used to mean 'haemorrhoids'. (The Swedish word was probably borrowed from the now obsolete German word goldene Ader, also with the literal meaning 'golden vein'). Zwick lists the same word with the gloss der goldene Adler 'the golden eagle'. This word šabarin is also found in Ramstedt's (1935) Kalmuck dictionary (šawrn, translated as der golden-adler 'the goldeagle' with a reference to Zwick), and it is listed by Krueger (1978/1984) who translates it as golden eagle, referring to Zwick and Ramstedt (but not to any of the texts that Krueger excerpted). I have not found the word šabarin or a similar word meaning 'eagle' in any Kalmuck or Mongolian dictionary, and it is unknown to native speakers consulted by me. However, there are similar words meaning 'haemorrhoids': Cyrillic Kalmuck шамбриг (šambrcg) (Korsunkiev 1992:57), Old Written Mongolian šambaram and Cyrillic Mongolian шамбарам (šambaram). Krueger lists the Written Kalmuck forms šambaram, šambrum, šamuruụn, and Ramstedt gives šamb $b^{b} r$, šambrrn, all meaning 'haemorrhoids'. Thus it seems that Rahmn was right and Zwick was wrong. My guess is that Zwick used Rahmn's material and misunderstood the Swedish àder 'vein' as corresponding to the German Adler 'eagle' (or perhaps made a slip of the pen and wrote Adler instead of Ader'vein').

\section{Conclusion}

Although Rahmn's Kalmuck grammar is short and sketchy and there are some misunderstandings in it, I think it still has an interest as documentation of the Kalmuck language at an early time. At the time when Rahmn wrote his grammar, no Kalmuck grammar had been published in any language. The first published grammars are those of Popov (1847), Bobrovnikov (1849) and Zwick (1851). The dictionary is even more valuable as documentation of the language. It is earlier 
than the published dictionaries in European languages (Zwick 1852, Golstunskij 1860) and contains a relatively large word material.

Rahmn's dictionary and grammar were not published in his time, but my impression is that they were more or less completed and that only minor additions and editing would have been needed to bring them to a publishable state. Perhaps he never intended to publish them, only to use them himself for his Bible translations. The fact that he wrote in Swedish suggests this, since it is not easy to imagine who, except Rahmn himself, would read works on Kalmuck in Swedish.

\section{References}

Bawden, Charles Roskelly 1985, Shamans, lamas and evangelicals: the English missionaries in Siberia, London: Routledge \& Kegan Paul

Birtalan, Ágnes 2003 Oirat. In: The Mongolic languages, ed. Juha Janhunen, London: Routledge, 210-228

Boberg, Folke 1946, Lessons in the Mongolian language, Stockholm: Filadelfia.

Boberg, Folke 1954, Mongolian-English dictionary, Stockholm: Filadelfia

Bobrovnikov, Aleksej Aleksandrovič 1849, Grammatika mongol'sko-kalmyckago jazyka [Grammar of the Mongolian-Kalmuck language], Kazan': Universitetskaja tipografija

Brusewitz, Hanna 1893, Cornelius Rahmn: vårt århundrades förste svenske missionär [Cornelius Rahmn: the first Swedish missionary of our century], Stockholm: Missionsbibliotek för folket

Doerfer, Gerhard 1965, Ältere westeuropäische Quellen zur kalmückischen Sprachgeschichte (Witsen 1692 bis Zwick 1827), Wiesbaden: Harrassowitz

Golstunskij, Konstantin Fedorovič 1860, Russko-kalmyckij slovar' [RussianKalmuck dictionary], Sankt-Peterburg

Jamca, Todobeyin 1999. Todo üzügiyin dürüm [Rules for the Clear script], Chìfēng: Öbör Monggoliyin šinjilekü uxān tehnig mergejiliyin kebleliyin xorō

Jansson, E. Alfred 1951, Cornelius Rahmn: 1800-talets förste svenske missionär [Cornelius Rahmn: the first Swedish missionary of the 19th century], Stockholm: Evangeliska Fosterlands-Stiftelsens bokförlag

Kara, György 2005, Books of the Mongolian nomads, Bloomington: Research Institute for Inner Asian Studies, Indiana University

Korsunkiev, Ceren Korsunkievič 1992, Kalmycko-russkij i russko-kalmyckij terminologičeskij slovar': medicina [Kalmuck-Russian and Russian-Kalmuck terminological dictionary: medicine], Èlista: Kalmyckoe knižnoe izdatel’stvo 
Krueger, John R. 1973, Circularity in Kalmyk dictionaries, Mongolia Society bulletin Vol. 12 (1973), No. 1-2, 52-70

Krueger, John R. 1975a, The Kalmyk-Mongolian vocabulary in Stralenberg's Geography of 1730, Stockholm: Almqvist och Wiksell

Krueger, John R. 1975b, Written Oirat and Kalmyk studies, Mongolian studies Vol. 2 (1975), 93-113

Krueger, John R. 1978/84, Materials for an Oirat-Mongolian to English citation dictionary (3 vols.), Bloomington: The Mongolia Society

Pallas, Peter Simon 1776/1801, Sammlungen historischer Nachrichten über die mongolischen Völkerschaften (2 vols.), St. Petersburg: Kayserliche Akademie der Wissenschaften

Popov, Aleksandr Vasil’evič 1847, Grammatika kalmyckago jazyka [Kalmuck grammar], Kazan': Universitetskaja tipografija

Poppe, Nicholas 1955. Renat's Kalmuck maps, Imago Mundi Vol. 12 (1955), 157-159

Ramstedt, Gustaf John 1935, Kalmückisches Wörterbuch, Helsinki: SuomalaisUgrilainen Seura

Strahlenberg, Philip Johan 1730, Das nord- und ostliche Theil von Europa und Asia, in so weit solches das gantze ruszische Reich mit Siberien und der Grossen Tatarey in sich begreiffet, in einer historisch-geographischen Beschreibung der alten und neuern Zeiten ..., Stockholm

Svantesson, Jan-Olof 2009a, Cornelius Rahmn's Kalmuck grammar, Turkic languages Vol. 13 (2009), 97-140

Svantesson, Jan-Olof 2009b, Cornelius Rahmn and his works on the Kalmuck language, Northeast Asian Studies (東北アジア研究) Vol 13 (2009), 111-126, Center for Northeast Asian Studies, Tohoku University, Sendai

Svantesson, Jan-Olof 2012, Cornelius Rahmn’s Kalmuck dictionary, Wiesbaden: Harrassowitz Verlag

Svantesson Jan-Olof; Tsendina, Anna; Karlsson, Anastasia; Franzén, Vivan 2005, The phonology of Mongolian, Oxford: Oxford University Press

Svenska Akademien 1893-, Ordbok över svenska språket utgiven av Svenska Akademien [Dictionary of the Swedish language published by the Swedish Academy], Lund: Gleerup [Also available on the internet: http://g3.spraakdata.gu.se/saob/] 
Teleman, Ulf 2002, Ära, rikedom och reda: svensk språkvård och språkpolitik under äldre nyare tid [Glory, wealth and order: Swedish language cultivation and politics in early modern time], Stockholm: Norstedts

Zwick, Heinrich August 1851, Gramatik der West-Mongolischen das ist Oirad oder Kalmükischen Sprache, [Villingen?]

Zwick, Heinrich August [1852?], Handbuch der westmongolischen Sprache, Villingen: Ferd. Förderer 


\title{
Block printing in the Buddhist Monasteries of Transbaikalia in the $19^{\text {th }}$ and early $20^{\text {th }}$ centuries: current archeography of the texts
}

\author{
Surun-Khanda D. Syrtypova (Severtsov's Institute of Ecology \& Evolution, \\ Russian Academy of Sciences, Moscow)
}

\section{Introduction: Methodology of study}

The block printing in the Buryat Buddhist monasteries was studied on the base of field archaeographic investigations in Buryatia and Chita region. The most valuable information about the number and thematic contents of literature in Tibetan and Mongolian languages, published in the monasteries of Transbaikalia, is provided by archival materials, as well as by the reference lists - garchags (Tib.: dkar chag), which were compiled by the Buryat publishers themselves. The statistical analysis allows us to assert that about $20 \%$ of all Buddhist literature presented in the Buryat region to the beginning of XX century was published in the local monasteries.

The Buryat monasteries had published precisely those texts that were required in large quantities for the local population, when the purchase and shipping of these books from abroad was very expensive. Therefore, on the content of these works, we can determine the specifics and regional peculiarities of the Buddhist tradition in Transbaikalia.

Buryat-Mongolian tribes settled very scarcely in the vast area and traditionally inhabited a territory around the Baikal lake to the North of Mongolia, including the present-day Republic of Buryatia, Irkutskaya oblast and Zabaikalskiy kray. For our archaeographic investigation I have used the methodology and model of Cultural 
Geography, when the vast territory was divided into ethno-cultural districts according to their natural and cultural opportunities. So, three various regions were chosen, differing in natural and ethno-cultural features:

1) Eastern Sayan Mountains, Okinskiy raion of Buryatia (parish of Jelgenskiy datsan ${ }^{1}$, from 1880)

2) Barguzin river valley of Buryatia (parish of Barguzinskiy datsan, from 1810)

3) Onon river valley, Zabaikalskiy krai (parish of Tsugolskiy datsan, from 1801).

Okinskiy raion of Buryatia is the westernmost edge of Buryatia, it is a mountainous area, isolated by natural rock landscape. Its cultural specificity was determined by the ethnic group of the Soyots. The livelihood of the Soyots was reindeer and yak breeding and hunting. In the second region, the Barguzin river valley, the mountain-taiga region stretches along the eastern coast of Baikal Lake and is located in the northern edge of Buryatia. The cultural characteristics of these region determine the presence of different ethnic groups here - Buryats, Evenks, the descendants of the exiled Chinese, Jewish Goldminers and others. In the third region, the Onon River valley in Zabaikalskiy krai, the arid steppes and the most south-eastern area is settled by the Khori Buryat and Hamnigan's tribes. Additionally, some point investigations were made in Chikoi river valley, in Kyahtinskiy raion of Buryatia and Krasnochikoiskiy raion of Zabaikalskiy krai, (Murochi, Tsongolskiy, ore Baldan Braibun datsan, from 1738), as it is a parish of the earliest Buddhist temple in Buryatia.

\footnotetext{
${ }^{1} \mathrm{~A}$ datsan is a teaching monastery in the Tibetan Buddhist tradition amongst the Mongols.
} 


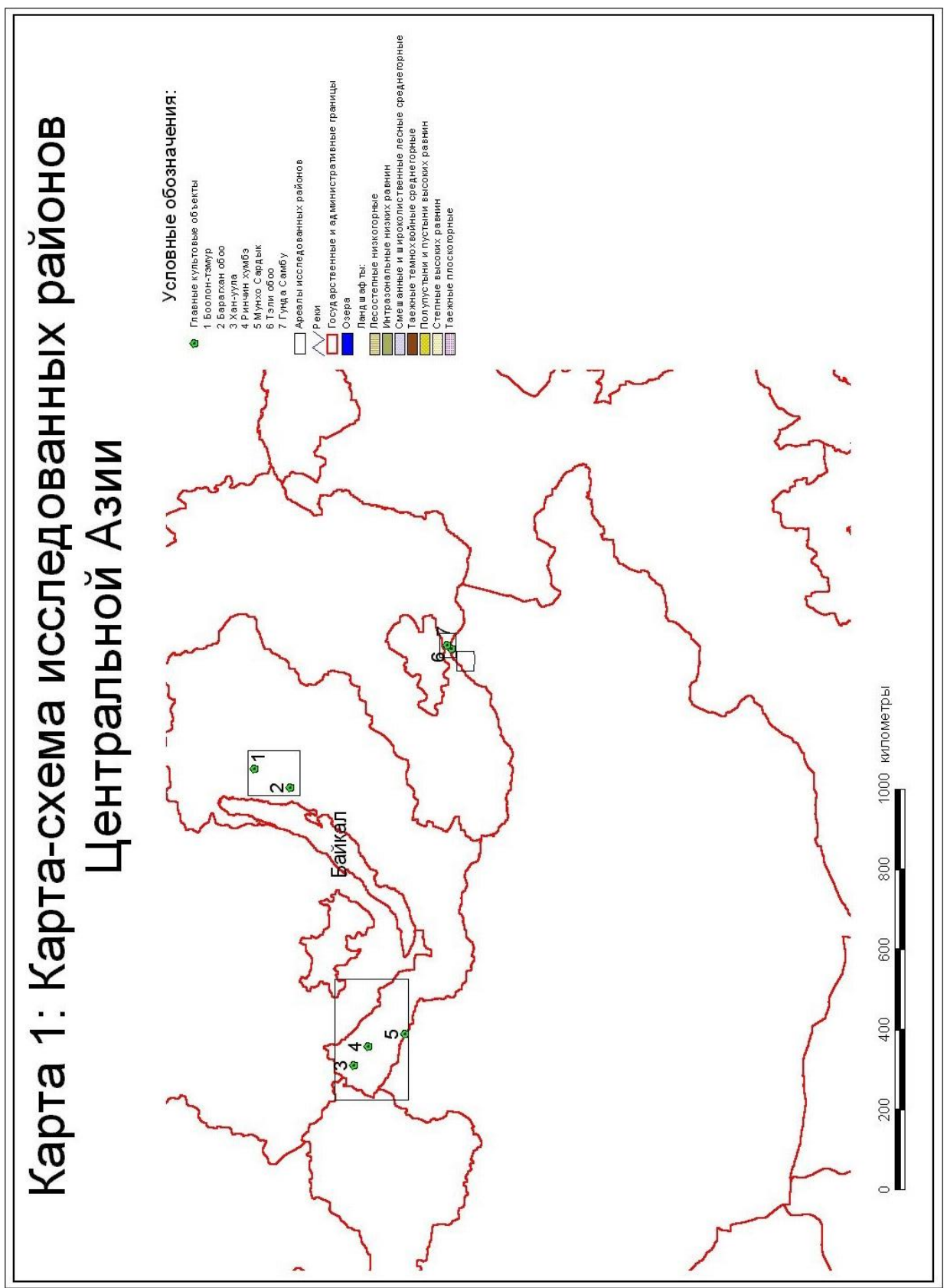

Figure 1: Map of the research regions. 
The population of all these regions traditionally engaged in nomadic pastoralism, hunting and fishing in different proportions corresponding to the local environmental condition. All that required an extensive space, given the conditions of a sharply continental climate ${ }^{2}$. And the intensity of the spread of Buddhism in its various outskirts was not the same and uniform all around. It was also dependent on the specific ethnic and cultural circumstances in each microdistrict. The extent of proximity to the major Tibetan-Mongolian Buddhist centers was very important, too. So in the southern regions, like the valleys of Chikoi river and Onon river we discovered much more inventories of Buddhist literature in the hands of private owners than in northern and north-eastern microdistricts, where shamanism was prevailing.

So, the whole region historically settled by Buryats we named Transbaikalye, it is not identical with the contemporary administrative division. The Buryat territory was the northernmost frontier of the spreading of Buddha's Teaching and considered as a far periphery of the main historical events in Central Asia. However, in Transbaikalia since the XVIIIth century there was a network of Buddhist temples and monasteries and those were developed into the Buddhist universities with their own system of education, publishing, medicine, art, astrology, etc.

It is necessary to note one more methodological trick that helped me to explore the problem. It is connected with the system of storing of Buddhist books in the depository of oriental manuscripts and xylographs of Ulan-Ude city (COMX), which appeared respectively to the formation history of this collection. The beginning of the library collection was initiated by Buryat scholars gathering Buddhist books from the closed temples and monasteries in the period of their destroying in 20-30s of the XX century. That is, it was not targeted gathering of something specific, but happened quite spontaneously and frontally. In the formation of the book depository the old Buryat lamas participated, who preserved the traditional Buddhist system of book classification. Later, up to the $70-80^{\text {s }}$ of the 20 th century the library received many small intact book collections of deceased old priests and literate laity believers. The integrity of these small libraries also had been preserved. Therefore, the Ulan-Ude collection can be used as a model for the study of Buddhist society and book culture of pre-revolutionary Buryatia in the XIXth and early XXth centuries ${ }^{3}$.

\footnotetext{
${ }^{2}$ Now this region occupies 1558,1 thousand $\mathrm{km}^{2}$. See: http://irkipedia.ru/content/sostav i_granicy_baykalskogo_regiona_atlas_2009_g (URL checked 17.06.16 J.R.)

3 The details of methodological approaches see: Syrtypova, S.D., Garmaeva Kh. Zh., Dashiev D.B., 2006. Tibetskiiy fond TsVRK IMBT SO RAN: struktura i soderzhanie. Ulan-Ude.
} 


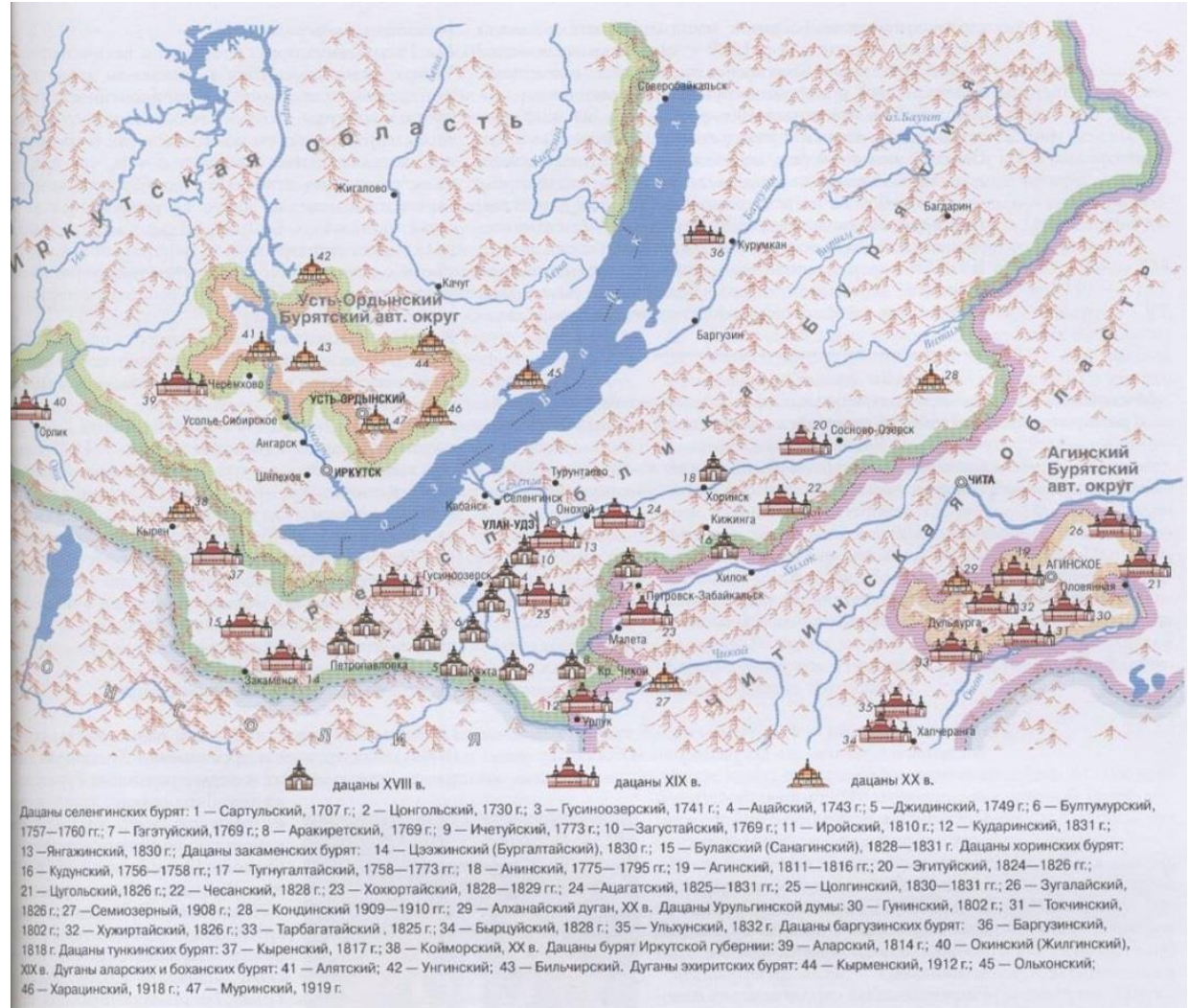

Figure 2: Locations of Buddhist monasteries and temples in Transbaikaliya XVIII to early XX centuries. [IKAB, 2001].

The fact that in the early XXth century, the study of Buddhism was successfully developed in Russia and farther in Europe is largely the merit of Buryat-Mongol Buddhists. The famous leading figures, founders of the academic Buddhist study in Russia such as S. Oldenburg, E. Obermiller, A. Vostrikov, M. Scherbatskoy, A. Rudnev etc. wrote their works and translated the Tibetan and Sanscrit Buddhist texts thanks to the selfless help of Buryat lamas, whose names remained anonymous for history. How was it possible, that such a remote Siberian province was capable to support and promote Buddhism? We can evaluate this by looking at the state and content of block-printing of Buryat monasteries in the 19th and early 20th centuries. 


\section{The subject of possession of Buddhist books}

Now we have three kinds of subjects of possession, using and storing of written Buddhist monuments in Transbaikalia of RF:

- State, departmental organizations (repository, libraries, museums and archives);

- Religious organizations (TBSR ${ }^{4}$, communities, monasteries, temples);

- Private owners (clergy, laity, collectors).

State depositories:

1. The largest collection of old Buddhist books in Transbaikalia now is the Center of Oriental Manuscripts IMBTS SB RAS, Ulan-Ude, Buryatia, which contains about 60.000-100.000 Tibetan texts in 10.000 volumes and 6000 Mongolian texts, as well as Audio and Photo materials of history of Buryatia.

2. A huge part of saved Buddhist books from Buryat monasteries are stored also in the depositories of St. Petersburg, that were moved from Buryat monasteries ${ }^{5}$. For example, in 1940 from railway station of Aga district two carriages with cult items had been sent to Leningrad, one of them was filed as books exclusively. The majority of these are stored now in the Institute of Oriental Manuscripts (Asiatic Museum) of Russian Academy of Sciences. The Tibetan collection consists of more than 20500 volumes $^{6}$.

3. The Oriental Department of St. Petersburg State University, where the library holds about 3000 items of Tibetan-Mongolian written heritage.

In Transbaikalia prior to the revolution of 1917 there was a high percentage of Buddhist clergy: 21\% in relation per capita, i. e. 130000 persons of all Buryat population were lamas (Tib.: bla ma; i. e. in Buryatia and Mongolia - the Buddhist priest) ${ }^{7}$. That means that $20-25 \%$ of Buryat population at least was literate in Ti-

\footnotetext{
${ }^{4}$ TBSR - The Traditional Buddhists Sangha of Russia, the largest Buddhist organization joining 26 communities of monasteries and temples in Buryatia, Irkutskaya oblast and Zabaikalskiy kray. TBRS is headed by the XXIV-th Khambo-Lama Damba Ayusheev; see (www.sangharussia.ru). The title of Bandido Khambo-Lama (Sanskr. pandita - scholar, Tib. mkhan po bla ma - the highest master, teacher) was established in 1764, beginning from Damba-Darzha Zayaev (1764-1776), the First Head (Khambo-Lama) of the Buddhist church in Russia.

${ }^{5}$ Report about the work done by the expedition of the USSR Academy of Sciences in BM ASSR, Chita Region on the selection and packaging of the liquidated property of Buddhist monasteries (datsans). P.105-119. SPbF RAS Archive. F-152, OP-1a ed.hr. 580.

${ }^{6}$ St. Petersburg's Oriental collections contain also many books gathered by famous scientists, who travelled to the East for research purposes: G.F. Miller (Gerhard Friedrich Müller) (1705-1783), Peter.Simon Pallas (1741-1811), P.L. Schilling von Kashtadt (Paul Ludwig Schilling v. Canstatt) (1786-1837), A.M. Poszdneev (1851-1920), G.Ts. Tsybikov (1873-1930), B. Baradiyn (1878-1937), S.F. Oldenburg (1963-1934), P.K. Kozlov (1863-1935), F.M. Shcherbatskoi (1866-1942), A.I. Vostrikov (1904-1937), E.E. Obermiller (Jewgeni Jewgenjewitsch Obermüller) (1901-1935), M.I. Tubyansky (1893-1937) and others.

${ }^{7}$ At the same time among the Muslim population of Russia, the ratio was one mullah for 300 people $(0.3 \%)$, and among the Orthodox Christians one priest per 1,000 people $(0.1 \%)$, but Buddhists had one lama per 12-15 persons. This according to the data of a memo to the Secretariat of Buryat Revo-
} 
betan and Mongolian script and they required Buddhist literature. The Buryat population in 1897 consisted of 289062 pers., including 180125 pers. in Zabaikalskaya guberniya, 108937 pers. in Irkutskaya guberniya ${ }^{8}$.

- According to the approximate calculations in 1935 the minimum number of Buddhist literature in 40 major Buryat datsans was 450 thousand volumes (400 pages on average) and estimated at 4.5 million rubles in prices of $1914^{9}$.

- This number (450.000 volumes) does not include books from libraries of small temples, chapels, private collections and the content of hundreds of Buddhist stupas, where hundreds of thousands volumes of Buddhist scriptures and other cult relics were stored.

- The estimated price (4.500.000 rub.) doesn't take into account the specially valuable publications - artistically copied jewelry editions with gold, silver, copper, iron, coral, pearl, malachite, turquoise, lapis lazuli inks on a black paper with special lacquer covering" (like the bKa' 'gyur of Tsugolskiy, Kyrenskiy and other datsans).

If about one half of the saved books are stored now in the depositories of UlanUde and St-Petersburg, another part of the books is in the possession of the believers, who are the traditional users of Buddhists texts - in the restored temples datsans (Tib.: sgrva tshan) and on the family altars belonging to private possessors. The religious communities, including active monasteries and temples, as well as private owners of the Buddhist book collections both are authentic users of Buddhist literature. However, the composition of the texts in these two groups varies. Sometimes Buddhist communities can have in their historical possession very rare and expansive editions. For instance, the Buddhist canonical Holy Scriptures bKa' 'gyur of the Tibetan Nartang monastery edition kept in Bursomon-Shergoljin country of Krasnochikoiskiy raion in Zabaikalskiy krai. The Tsugolskoi datsan has a precious manuscript of the bKa' 'gyur edition, made by the local master Boryn Shoybon in the beginning of the 20th century with the use of 9 types of precious metals and minerals - gold, silver, copper, coral, turquoise, lapis lazuli, malachite, pearl and shell.

lutionary Committee of the Buryat Autonomous Soviet Socialist Republic, May 18, 1922. [Protokol №38. NARB. F. R-248. Op. 1. D.82. P. 54-54r. Copy].

${ }^{8}$ See: the data of "The 1-st General Census of Population of Russian Empire" 1897. [Perepis' 1897, v. LXXIV, 83; v. LXXV, 81].

${ }^{9}$ From the information in the Central Executive Committee of the Anti-religious museum of BMSSR about the Buddhist-Lamaist literature, located in datsans of BMSSR. 1935. [NARB. F.R-248. Op.3. D.21. P.46-48. Copy]. 


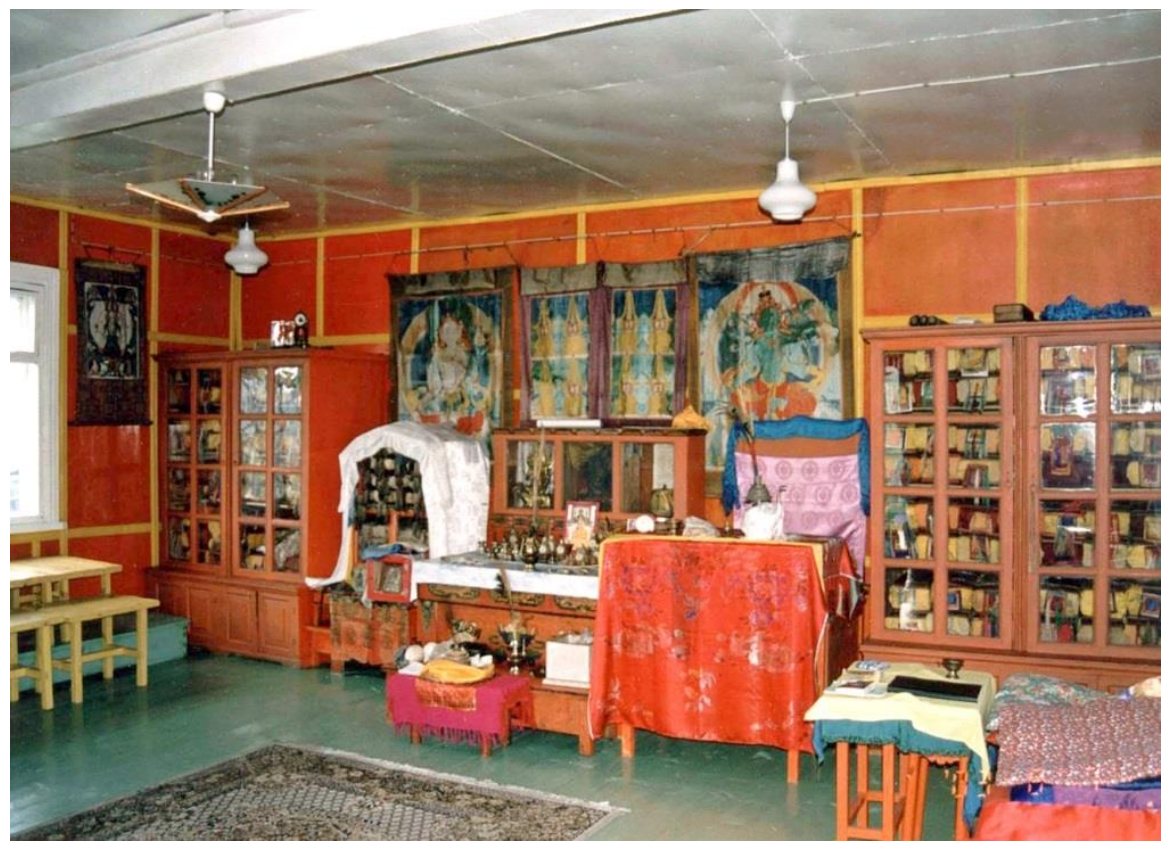

Figure 3: The Holy Scriptures bKa' 'gyur of the Tibetan Nartang monastery edition in Bursomon-Shergoljin country of Krasnochikoiskiy raion, Zabaikalskiy krai.

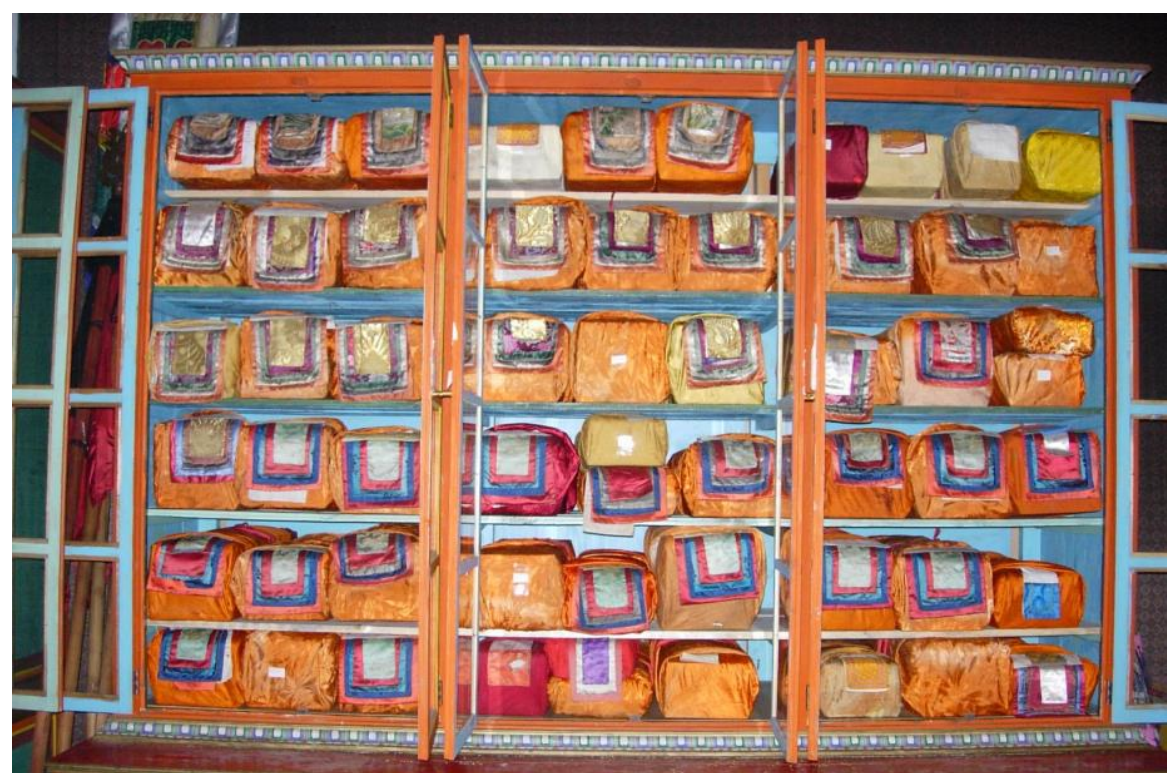

Figure 4-1: The precious manuscript bKa' 'gyur in Tsugolskiy datsan of Zabaikalskiy krai. 


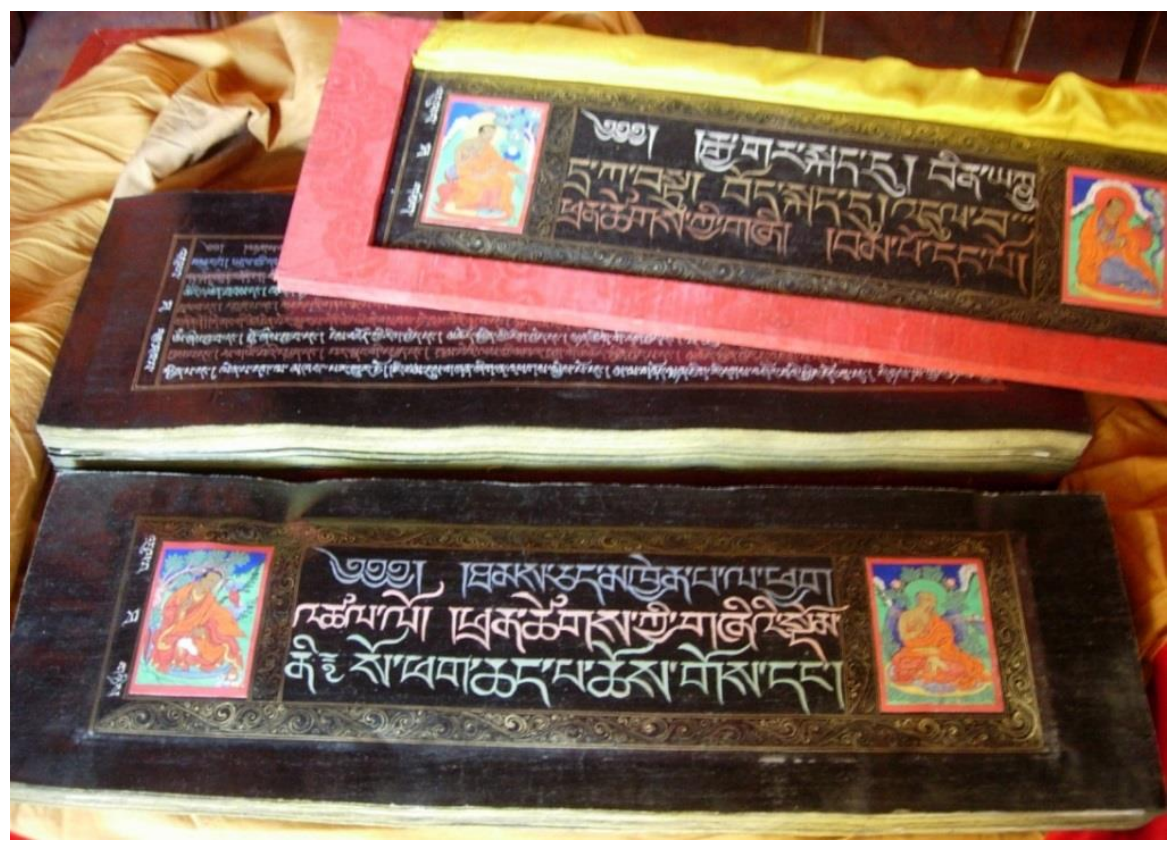

Figure 4-2: The open volume of 'Tsugolskiy bKa' 'gyur.

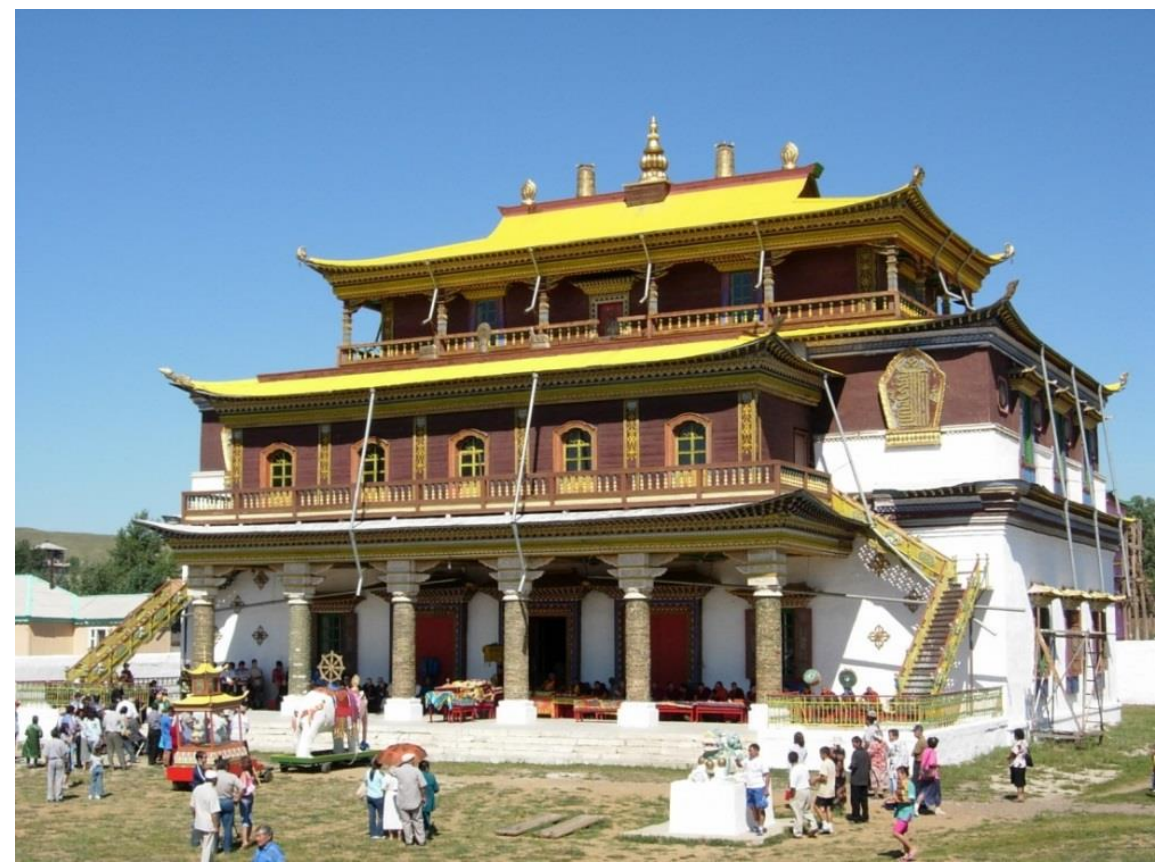

Figure 4-3: Tsugol datsan of Zabaikalskiy krai. The Cathedral temple (Tib.: tshogs chen 'du khang). 
The books stored in the family altars generally have limited diversity of titles. Usually, we can find here the most popular canonical texts (like Āryasuvarņaprabhāsottama, Vajracchedikā-prajñāpāramitā-sūtra, Așțasāhasrikā Prajñāpāramitā-sūtra, Saddharma-Puṇdarìka-sūtra and others), the small ritual texts, popular Mongolian books of didactic literature, jatakas and sutras. Sometimes family treasures include voluminous canonical texts like the Śatasāhasrikā Prajñāpāramitā Sūtra, called also the Mahāprajñāpāramitā Sūtra or Yum in 100,000 lines and 16 volumes, as DambiNima Tsyrendashiev, who kept books from XVIII-th century. The field investigations make possible some interesting observations of the spiritual everyday life of traditional Buddhists.

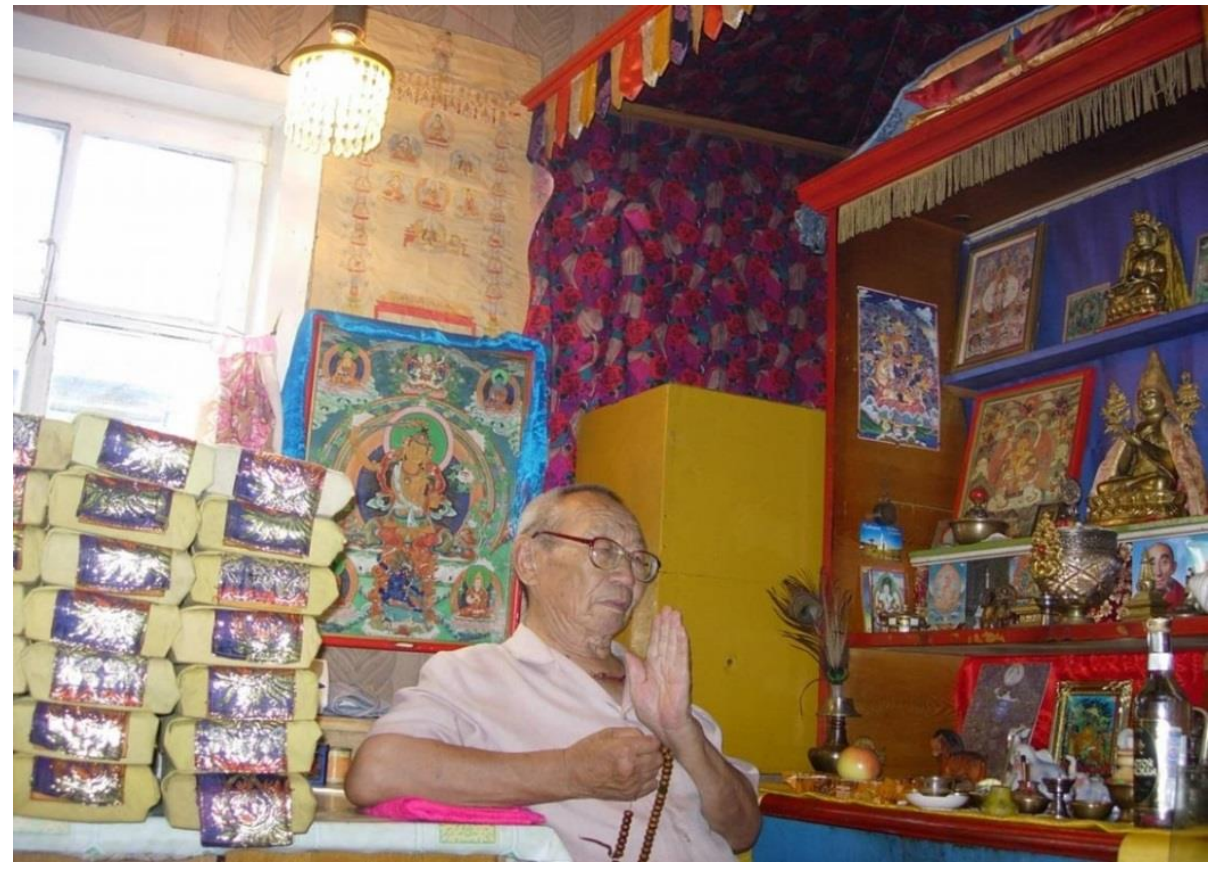

Figure 5: Dambi-Nima Tsyrendashiev and his Śatasāhasrikā Prajñāpāramitā Sūtra (on left), usually stored in a special box.

\section{The research sources}

\subsection{Archival materials and historical chronicles}

The reliable evidence about blockprinting in the Buryat monasteries refers to the Russian and Mongolian material of the XIX century. This evidence relates to the rather late period - the beginning of the 19th century, but they substantiated block printing among Buryats as a usual, ordinary fact. For example, in 1820 Khambo- 
Lama Ishizhamsuev ${ }^{10}$ and mongolist A.V. Igumnov on demand by M.M. Speranskiy $^{11}$ made the register of books in Mongolian language. Among them was listed a book under the title "Dara ehe-yin qorin nigen muryul" (Worship of 21 Tara goddesses) printed by red ink in Gusinoozersiy datsan ${ }^{12}$.

In 1830 the Russian emperor ordered to send to Eastern Siberia the General Baron von Schilling to examine the Buddhist regions, settled by Buryat tribes. Dambi-Zhalsan Lombotsyrenov, the author of the chronicle "History of Selenginskiy Buryat-Mongols" wrote about this visit: "In Iroyskiy datsan for him the books were printed with wooden matrix of wild apple tree, as well as the copies of various images of Buddhist deities cast in gold and silver, copper and bronze, were copied from their canvas pattern. These items have been collected in abundance to be sent to Russia" 13 . The items and books from the Schilling collection are stored now in the museums of St. Petersburg - Museum of Ethnography and Anthropology and the Institute of Oriental Manuscripts - the former Imperial Kunstkammera and Imperial Asiatic Museum.

In 1877, the Bishop of the Selenginskiy region, Martinian, reported to the police about unsanctioned publishing activities in Tsugolsky datsans. During the investigation more than thousand wooden printed boards (Tib.: dpar; Mong.: keb) with Tibetan and Mongolian texts were discovered. As a result, the typography of Tsugolsky datsan was immediately closed and sealed and the Shiretui (abbot) was reprimanded. But, a bit later, Russian imperial authorities found it more profitable to allow publishing in the Buddhist monasteries. The Russian Military Governor of Transbaikalye was of the view that "the permission of printing in the Buryat datsans would stop the need to buy books abroad", that meant a saving of resources within the country and limiting the influence from abroad. In 1880 book printing was already established in many officially approved printing houses of Gusinoozerskiy, Aninskiy, Aginskiy, Tsugolskiy, Chesanskiy, Hohyurtayskiy, Egituisky, Tsulginskiy and other datsans.

In 1887 the Russian count Esper Ukhtomskiy was sent to Transbaikalia for a revision of Buddhist monasteries. Khambo-lama Dampil Gomboyev ${ }^{14}$ informed him, that, from the 34 big monasteries of Buryatia 29 datsans had the printing courts for publishing the Tibetan and Mongolian Buddhist texts.

\footnotetext{
10 Gavan Ishizhamsuev (1809-1839) was the V-th Bandido Khambo-Lama of the South-Eastern Siberia.

${ }^{11}$ Mikhail Speransky (1772-1839) - a prominent statesman and reformer, lawmaker, the founder of the Russian legal science and theory of law, an honorary member of the Imperial Academy of Sciences, was a Governor-General of Siberia 1819-1821. He was the author of the Statute "On governance of natives" (1822) - a legislative act of the Russian Empire, which established a system of managing the indigenous peoples of Siberia. Most of its provisions were kept in force until the February Revolution of 1917.

12 [Lamaizm v Buryatii, 1983: 74].

13 [Lombotsirenov, 1995: 122]

${ }^{14}$ Dampil Gomboev was the X-th Buryat Pandido Khambo-Lama (1876-1896).
} 


\subsection{Garchags and xylographs}

Apart from the data of fiscal services by Russian imperial power we can use the reference lists of printed books in Buddhist monasteries - garchags (Tib.: dkar chag). Garchags of published literature in the Mongolian and Tibetan languages were issued in different Buryat datsans ${ }^{15}$. The complex study of these lists and xylographs published in the local printing houses allows us to imagine the general outline of the condition of Buddhist religion and the degree of its development among Buryat-Mongols of Transbaykalia.

The book publishing in the Buryat monasteries was specialized to a certain extent according to what faculties structured the monastery. For example, the publishing of medical treatises, practical guides, compilations of medicinal prescriptions for healers has been concentrated in Aginskiy datsan. The famous Tibetan treatise "Four Tantras" (Tib.: Rgyud bzhi), which is the basic text of Tibetan and Mongolian medicine was issued also here. In Aginskiy datsan there was also a powerful Faculty of Philosophy, for educational needs of which the voluminous texts of Vinaya Pitaka (Tib.: 'Dul ba), Logic (Tib.: Tshad ma), Prajnaparamita (Tib.: Phar phyin), etc were published. Among the small number of publications of Barguzinsky datsan the Yamantaka (Tib.: 'jigs byed) tantric deity's texts were prominent. Gusinoozyorskiy datsan was known for its religious Cham mystery. So here, more widely than anywhere else, the Kalachakra Tantra texts were published.

In the beginning of the twentieth century, according to the "Catalogue of Khambo-Lama, 1911", the largest number of Buddhist texts were published in Tsugolsky datsan in Onon river valley - 326 titles, of which 268 titles were in the Tibetan language, 49 in the Mongolian language and 9 prints diagrams with mantras and images of deities ${ }^{16}$. Comparison of the contents of this document with original garchags of Tsugolsky datsans from the Tibetan Fund of COMX in UlanUde shows that the "Catalogue of Khambo-Lama, 1911" was not exhaustive, although it was the most extensive.

Garchags of Tsugolsky datsan were printed as a systematic list of published texts. The titles of publications are distributed by format ${ }^{17}$, and there is a tendency to substantiate the systematization, when the works are grouped according to branches of Buddhist knowledge in order of priority. Indeed, three printed garchags of Tsugolskiy datsan are the three parts of the united list with application and separate pagination. In the first part the long format editions accounted for 59 titles, in the second part there are 58 titles of medium format editions, in the third part - small-format publications in the amount of 93 titles; totally, there were registered 210 items.

\footnotetext{
15 [Chojilsurung, 1959; Bethlenfalvy, 1972; Sazykin, 1992; Syrtypova S.D., Kh. Zh. Garmaeva, A.A. Bazarov, 2006].

16 This document was discovered by Academician B. Rinchen and published in the series "Sata Pitaka Series" of Rakhu Vira \& Lokesh Candra.

${ }_{17}^{1}$ [Garchag, 1, 2, 3] - bkra shis chos phel gling gi bar tho; par tho 'bring gi skor la; par thung gi skor la.
} 


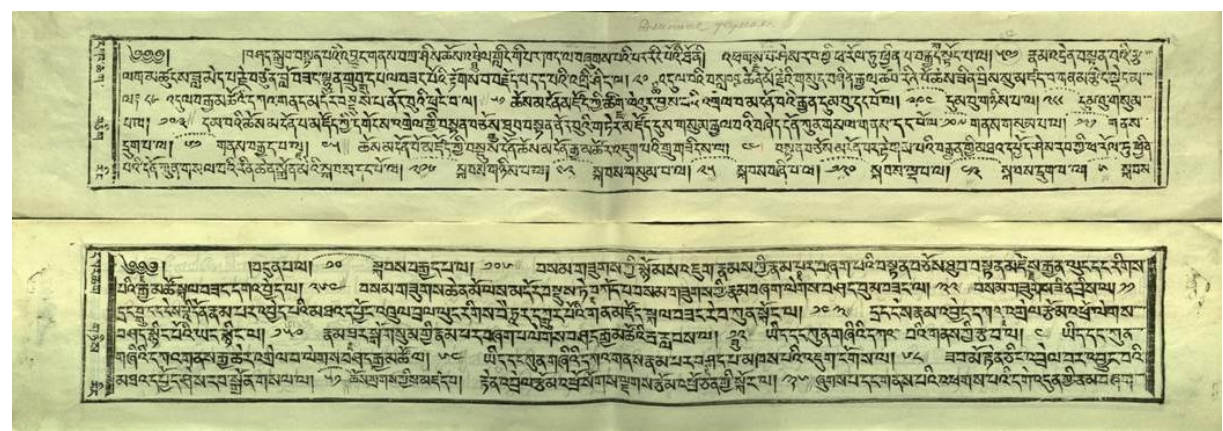

Figure 6: The garchag of long format xylographs printed in Tsugolskiy datsan.

It should be noted, that the garchags available to us do not contain a complete list of published literature from Buryatia. There are many requested and widespread texts, as well as the rare historical texts, which are not included in the known garchags. At the same time, there are some texts of lists, which are not found in library collections. For example, among the current Buryat clergy the xylographic set of texts of ritual drink offering "Serzhem natsog" (Tib.: gser skyems rna tshogs) printed in Kizhinginskiy datsan is very popular. However, it was not listed in the currently available garchags. Another example, that of the wellknown Buddhist scholar B.D. Dandaron (1914-1973), who claimed the existence of a woodblock publication of the complete works of Chahar Lobsang Tsultim (Cha har bge bshes blo bzang tshul khrims, 1740-1810) in Aginskiy datsan, has not yet received confirmation.

The features of Buryat Buddhist books printing

- The main technology was xylography with wooden matrices.

- The main scripts were Tibetan and Mongolian, sometimes Sanscrit, but Tibetan was prominent.

- There was used the paper of Russian manufactories (Fabrika Naslednikov Sumkina №6, №7, Uspenskoi Fabriki, Andreevskoi, Pervushina, Yatez', Tatarovskaya, Protasyeva, Sergeeva, Kosinskaya, Reiner, Nevskaya and others).

- The high quality of carving, the letters are very crisp, neat and elegant.

- The publishers specialized depending on the profile of each datsan (Aginskiy in Medicine, Tsugolsky - in Philosophy, Barguzinskiy - in Tantra etc).

- Among the most popular published books were:

1) some canonical texts (like Äryaswuarnaprabhāsottama, Vajracchedikēprajñāpāramitā-sūtra, Saddharma Punḍarika sütra),

2) the ritual literature (Tib.: cho ga - gsangs, gser skyems, )

3) the scholastic literature (Tib.: chos sgrwa) by different authors of Vajrayana Buddhism. 


\section{Conclusion}

Many questions of Tibetan and Mongolian book publishing in the different Buddhists regions are not yet clear. Just in the territory of residence of Russian Buryats such centers numbered at least 30 . Because of the huge losses of the written heritage in the XX century, the problem of reconstructing of the history of block printing among the Mongolic peoples is extremely difficult. However, the new historical realities, advanced technical features allow a creation of international corporative research projects in which the joint efforts of specialists could bring significant results.

Additional notes, Aug 2016:

Just lately, while the publication was preparing, some new details were discovered about the block printing of Aginskiy datsan, which was the nearest neighbor of Tsugolsky datsan. It concerns the xylography sets, testifying to a certain level of publishing activity of Buddhist monasteries in Siberia. In particular, there were found reference lists and texts confirming the publication of collected works of Tibetan authors and collections of works composing single theme. For instance:

1) The collected works of 33 texts with $628 \mathrm{ff}$. by dBang phyug rje don yod mkhas grub (Sgrub brgyud bstan pa'I mnga'a bdag grub pa'I dbang phyug rje don yod mkhas grub kyi gsung 'bum bod chen gcig dkar chag dang bcas)

2) The collected works of 32 texts with 313 ff. by Ye shes rgya mtsho (Dpal ldan 'bras spungs blo gsal gling gi bshes gnyen chen po stag po youngs 'dzin chu bzang pa ye shes rgya mtsho'I gsung 'bum lam rim dang gsan ma gtog bod gcig dkar chag bcas)

3) 8 billingiual Tibetan-Mongolian texts of different characters (Bod sog shan sbyar ma'i skor)

4) The set of Hayagriva idam deity's 99 texts with 1289 ff. in 3 volumes by famous Tibetan author Tho'u brwan pa dharma badzras (Mkhas shing grub dbang rje tho'u brwan pa dharma badzras mdzad pa'I rta mgrin chos skor bod gsum dkar chag bcas)

5) The set of 78 deities sadhana texts (Yi dam kyi sgrub thabs dang bsrung ma' gtor chog sogs 'don cha thor bu sna tshogd kyi skor).

Data were obtained during my last visit to Agnisky and Tsugotsky datsans in May this year thanks to research carried out at the Buddhist Academy of Aginskiy datsan, led by Did-Khambo Tsyren-lama Dondukbaev and Lector Dmitry Shakhanov ${ }^{18}$.

18 See also: [Schakhanov D., 2015.- Ksilograficheskiye izdaniya Aginskogo datsana na tibetskom i mongol'skom yazykakh: struktura karchakov i problema identifikatsii tekstov // Dukhovnost'. Nravstvennost'. Traditsii. Istoriya i sovremennost'. Materialy regional'noy nauchno-prakticheskoy konferentsii. poselok Aginskoye 15.05.2015. s.86-92 - The block printing of Aginskiy datsan in Tibetan and Mongolian languages: the structure of garchags and the problem of identification of texts. Spirituality. Morality. Traditions. 


\section{References}

Bethlenfalvy, 1972, A Tibetan catalogue of the blocks of the lamaist printing house in Aginsk. In: Acta Orientalia Academiae Scientiarum Hungaricae. Tomus XXV, fasc. 1-3, 1972. PP. 53-75.

Catalogue of Khambo-Lama, 1911, Catalogue of printing blocks of Buddhist monasteries in Transbaikalia. In Sata Pițaka Series, vol. 11, Four Mongolian historical Records of prof. Dr. Rinchen. New Delhi. P. 71-121.

Chojilsurung, 1959, Čoyjilsurung D. Buriyad modun bar nom-un tabun garcig. In Hel zokiol sudlal. T. I, fasc. 16. Ulaanbaatar.

Garchag 1, Tib.: bkra shis chos phel gling gi bar tho. (The list of long format xylographs of Tsugolsky datsans). In the Tibetan Fund of COMX IMBT SB.

Garchag 2, Tib.: par tho 'bring gi skor la. (The list of middle format xylographs of Tsugolsky datsans). In the Tibetan Fund of COMX IMBT SB.

Garchag 2, Tib.: par thung gi skor la. (The list of short format xylographs of Tsugolsky datsans). In the Tibetan Fund of COMX IMBT SB.

IKAB, 2001, Istoriko-kultur'nyi atlas Buriatii. Moscow.

Lamaizm v Buryatii, 1983. - Lamaizm v Buryatii XVIII - early XX cen. Galdanova G.R., Gerasimova K.M., Dashiev D.B. Novosibirsk, «Nauka».

Lombotsirenov, 1995, Lombotsirenov Dambi-Jaltsan. Istoriya selenginskih buryatmongolov. In: Buryatskie letopisi. Ual-Ude.

Perepis' 1897, The 1-st General Census of Population of Russian Empire 1897. v. LXXIV, 83; v. LXXV, 81.

Sazykin, 1992. Chetyre kataloga ksilografov Aginskogo datsana iz sobraniy mongolskogo fonda rukopisnogo otdela LO IV AN SSSR. In: Tyurkskie i mongolskie pismennye pamyatniki. Tekstologicheskie i kulturovedcheskie aspekty issledovaniya. Moskva.

Syrtypova S.D., Kh. Zh. Garmaeva, A.A. Bazarov, 2006. Buddiiskie knigopechatanie Buriatii XIX-nachala XX v. Ulaanbaatar: Admon.

Syrtypova S.D., Kh. Zh. Garmaeva, D.B. Dashiev. 2006. Tibetskii fond TsVRK IMBT SO RAN: struktura i soderzhanie. Ulan-Ude. 



\title{
Cataloguing the Berlin Manchu Collection
}

\author{
Hartmut Walravens (Berlin)
}

\section{Basics}

A note on the term Manchu the etymology of which is not certain to this day. It is transliterated and transcribed in various ways: Manju. The eminent Manchu expert Walter Fuchs preferred the spelling Mandju, Klaproth wrote mandshuisch, or mandchou, linguists like K. H. Menges chose Manžu - the trend goes towards Manju. More problematic is the adjective - Mandschurisch, Manchurian, mańčžurskij, as a term for the language probably derived from manjurambi «to speak Manchu», a term which according to Wilhelm Radloff tended to adopt a negative meaning, at least with the Sibe «speaking bad Manchu». ${ }^{1}$ As a matter of fact, the Manchus at the end of the 19th century tended to pronounce the words according to Chinese syllables which made their talk (if one may call it talk) hard to understand.

Manchu used to be the only written language of the Manchu-Tungus language group; it is written by a script derived from Mongolian and adapted to the special needs of Manchu. After the conquest of China, Manchu and Chinese were the two official languages of the empire, and large archives are preserved in Manchu versions (not necessarily Manchu translations); Manchu has found more interest lately as it is indispensable for Qing Studies. The unfounded contempt of Sinologists - a stigma of the 19th cent. - is hopefully forgotten by now.

\footnotetext{
1 Wilhelm Radloff mentions this in a letter to Conon von der Gabelentz. It is in the course of publication under the title «Hans Conon von der Gabelentz (1807-1874) und sein Umkreis».
} 
Sibe (Chin. Xibo) is the Manchu language of the banner people who were resettled from Manchuria to the Ili area as a consequence of the war against the Dsungars. The Manchu language was preserved in a very pure state in this remote border area and became only much affected by Chinese loan-words in recent times, e. g. terms for modern administrative structures, party organisations etc. The Sibe are listed as a minority of their own in China.

\section{Manchu Books in the Berlin State Library}

There are Manchu books in several Berlin collections like the East Asian Seminar Library (now administered by the Education Library) of the Free University and the Ethnological Museum but the oldest and largest are undoubtedly the holdings of the Berlin State Library. These materials were to a large degree covered by a union catalogue of Manchu books in Germany, by Walter Fuchs, published in $1966^{2}$, which is still an excellent reference tool. There are some shortcomings, however, from today's point of view:

Except for some particularly rare items, the Manchu books are given as a title list in the appendix only, without full description. In order to provide full records all items had to be re-catalogued - tracked down, inspected, or considered lost or displaced. A cataloguing schema was developed starting with catalogue number, title, size, "margin title", followed by information on prefaces and introductions, author and publisher, and the collation.

Bibliographic references to some important catalogues are included, also information on secondary literature (studies, translations). Needless to say that Chinese characters and titles in other languages, e. g. Mongolian and Tibetan were entered.

It was decided to arrange the entries not by subject matter which seems to be the most user-friendly way of handling the issue but by call numbers, i. e. as presentation in the order of a shelf-list. The reason was simply that there were considerable difficulties locating possible Manchu items, and up to the last minute literally, new (or old) material turned up. Because of the provenance and locations the shelf-list approach turned out to be the most successful and promising.

It was not only the question whether an item was still in the place the known call number indicated; it became clear also that call numbers had been changed over the last two hundred years, items were given away as duplicates or exchanged for other items. Some of the original accession information was not precise, e. g. a listing «three manuscripts» in the Möllendorff catalogue.

At Fuchs' time the present Berlin State Library was still housed in the Marburg Castle and in a consolidation phase; there was no guarantee that all Manchu books were found, or definitively marked «lost» or «displaced». Besides checking the

2 Walter Fuchs: Chinesische und mandjurische Handscbriften und seltene Drucke. Wiesbaden: Steiner 1966. (Verzeichnis der orientalischen Handschriften in Deutschland 12,1.) 
stacks, old lists had to be compared, call number lists from Kraków reviewed. In a few cases fascicles were discovered were they did not belong - were they just misplaced, or new items? Fragments?

The same was true for the East Berlin Deutsche Staatsbibliothek which was still in a consolidation phase after the heavy losses caused by the war. A lot of research work had to be done which had partly been conducted fortunately by Helga Keller who knew the East Berlin collection very well.

The Berlinka holdings of the Jagiellonian Library (material stored in Eastern Germany which became Polish territory after the war, and is now stored in Kraków) were neither listed nor accessible at that time (appr. 100 Manchu titles). The only way to get to a description of the material was to work on the spot as the library neither had a language expert nor catalogues for this material. A week of hard work did not solve all questions but led to a solid overview of the Manchu holdings there.

After the publication of Fuchs' catalogue (the ms. was finished in ca. 1964) some more Manchu items were added to the collection; others, e. g. Mongolian books with a Manchu text version, were tracked down later on. Some items could not be found - they may have been misplaced, or lost. Especially considering the frequent reshuffling of the holdings on account of the refurbishment of the buildings this was a likely option. A number of losses apparently happened already before WW II but this was not evident from the beginning. After checking and comparing records this sometimes seemed to be the most likely story.

The situation was complicated by the fact that the Manchu holdings were and are divided between the East Asian and the Oriental Dept. This was owing to the historical development - the East Asian Dept. was only created in 1922. Therefore the Hirth and the Möllendorff collections as early acquisitions remained with the Oriental holdings. It also was ruled that manuscripts in general should be administered by the Oriental Dept. Therefore the relatively recent acquisition of the Polevoj material (practically all manuscripts) went there. Also a number of polyglot items whether ms. or printed are there as the older Tibetan and Mongolian books belong there in toto.

Therefore a considerable number of material had to be checked for items which might contain a Manchu language version. There were a few misattributions, and sometimes the Manchu was not recorded but most items were in the end found and listed.

A considerable Sibe collection (about 120 titles) was acquired only just before the new catalogue was finished. It is probably the largest such collection in a Western library now. 


\section{The New Catalogue}

tries to provide a reliable survey of the present collection (appr. 550 entries), including the part held by the Jagiellonian Library, and clearly marking lost items. Thus it also serves as a historical record of the former holdings some of which go back more than 200 years.

The preparation of the catalogue required time-consuming editing, some research on the history of the collections, preparation of indices, selection of photographs ... the usual routine, of course.

As the catalogue was the author's private project and did not get any funding from the library or any other institution, there was neither a time-frame nor rules or style-sheet for the work, except that it seemed desirable to include the volume in the VOHD series [Verzeichnis der orientalischen Handschriften in Deutschland] edited by the Göttingen Academy of Sciences. This provided a lot of leeway, and made work very pleasant, especially as library colleagues did their best to help with research and information.

Because of the size of the collection it was not possible to give an illustration for each entry but a considerable number of reproductions were included.

There are still a few doubts left, the most tantalizing one is connected with the following two manuscripts:

Ms. $\sin .21$

Diploma Sinico-Tataricum pro J. A. Schallii parentibus et majoribus Seren ${ }^{\mathrm{mo}}$ et Potentimo Electori Brandenburg Dno suo clem ${ }^{\text {mo }}$ offer. d. 19 Julij 1683 A[ndreas] Müller Greiffenhag. ${ }^{3}$

Diploma awarded by the Shun-chih Emperor, 1651, to the grandmother of the Jesuit Adam Schall, thus giving her the posthumous rank of a Shuren (rank 8-9). Scroll in three colours (purple, red and yellow) on a rolle in a case. There are Latin annotations to the individual Chinese characters. This copy was prepared by Andreas Müller and submitted to the Great Elector. The text is only in Chinese.

The known eulogies and awards of Adam Schall were circulated as booklets; the original imperial document may well have been a scroll but does not seem to exist anymore; Müller, on the other hand, seems to have had access to a scroll, as he would have hardly chosen a scroll for his copy.

\footnotetext{
${ }^{3}$ Andreas Müller, see below.
} 
Ms. $\sin .23$

is also in the form of a scroll; it is an apograph by Andreas Müller.

Given title:

Litterae Tartaro-Sinicae quas misit Sinarum \& Tartariae Chanus per Patrem e S. J. ad Leopoldum Imperatorem, i. e. «Letters by the Kangxi Emperor, dated 4XII-1668, to Emperor Leopold».

The original of the letters is unidentified.

Eva Kraft wrote, in the exhibition catalogue China und Europa. Berlin 1970, S. 24:

«We also find a copy of a letter by the young Kangxi Emperor dated 4-XII-1668. This document addressed to Emperor Leopold I. was forwarded to Müller for translation, as reported by Küster.»

Cf. Georg Gottfried Küster: Altes und Neues Berlin II. Berlin: Haude \& Spener 1752, 1015-1016, mentions two letters of 19 May 1682, one to the Great Elector, the other one to Müller. Details on the Chinese letter were not given. The letter in question is not mentioned in Müller's catalogue of the Berlin collection (around 1683) (see below) possibly because the present copy was made shortly afterwards.

Inspection of the item (kept in Kraków) proved that it is not a «letter» but belongs to the genre of Litterae patentes, and turns out to be the Manchu version of Ms. sin. 21, the patent for Father Schall's grandparents. Usually the Chinese and Manchu texts of such "patents» are written on the same scroll, the Manchu from left to right, the Chinese from right to left, and at the meeting point there is the imperial seal and the date of issue. Why Müller copied the texts on different scrolls is not clear.

The Manchu text of this award for P. Schall's grandparents (1651) seems to be unknown so far. The Chinese text is available as a booklet in several collections, e. g. the Vatican Library and the Austrian National Library; it is not accompanied by the Manchu text, however.

What is puzzling to the cataloguer is

- that the alleged letters from the Kangxi Emperor to Emperor Leopold an important political matter - do not seem to exist, despite their mentioning in secondary literature.

- that the litterae were interpreted as epistolae but are probably identical with the litterae patentes preserved under the mentioned call number.

- that the items in question are only available as copies not in the original. We only have Müller's word for it.

- that the original (Manchu) text seems to be unknown, at least it has not come to light so far. 


\section{A few words about the main collections}

The oldest Chinese collection was formed by the Great Elector of Brandenburg in order to get first-hand information on the profitable East Asia trade; the theologist and Orientalist Andreas Müller4(1630?-1694) served as his advisor in things Chinese - he published the first printed catalogue of the collection about 1683, which listed already two Manchu items namely the forecast of the sun eclipse of 1669 (Ms. sin. [= L.S.] 22) and a copy of an alleged letter of the young Kangxi emperor to Emperor Leopold of 1668 (Ms. sin. [= L.S. 23]), which had been sent to Müller for translation.

Müller's successor as curator of the Chinese collection was the Elector's personal physician Christian Mentzel ${ }^{5}$, a scholar with a worldwide network and active member of the Academia Naturae Curiosorum. We may judge his command of Chinese by a small Chinese dictionary ${ }^{6}$ and a portrait of the Great Elector with Chinese captions.

Regarding further Manchu acquisitions we only learn what Julius Klaproth ${ }^{7}$ communicated in the preface to his catalogue of the Chinese collection in $1810 ; 8$ some were provided by Klaproth (1783-1835) himself, as he said that he enriched the collection; it is also known from his correspondence that he bought and sold Chinese and Manchu books. Klaproth remarked (p. VIII):

"Seit seinem [d. h. Mentzels] Tode 1702 bis auf unsere Zeiten wurden die Chinesischen
Sammlungen der Bibliothek nicht vermehrt. Erst im Jahre 1810 überschickete ich dersel-
ben einige Chinesische, Mandshuische und Mongolische Bücher, und im folgenden erhielt
sie durch mich einen ansehnlichen Zuwachs an lexicographischen Werken, die ich von der
Chinesisch-Russischen Gränze mitgebracht hatte. Auch vertauschte ich ihr damals meine
übrigen Dubletten, gegen das eine der beiden Exemplare des 通鑑Thüng-kiän, oder der
grossen Reichsannalen. Durch diese Vermehrungen befindet sich nun auf der Bibliothek,
nicht nur ein sehr brauchbarer Apparat zum Studium der Chinesischen Sprache, sondern

4 Vgl. Hans Wehr: Andreas Müller, 1630-1694. Pommersche Lebensbilder 4.1966, 21-35; Donald F. Lach: The Chinese studies of Andreas Müller. Journal of the American Oriental Society 60.1940, 564-575; Lothar Noack, Jürgen Splett: Andreas Müller. Bio-Bibliographien. Brandenburgische Gelehrte der Früben Neuzeit. Berlin-Cöln 1640-1688. Berlin: Akademie Verlag 1997, 272-293.

${ }^{5}$ Christian Mentzel, 1622-1701, Leibarzt of the Great Elector, succeeded Andreas Müller als Bibliothekar as Chinese librarian. Cf. Walter Artelt: Christian Mentzel. Leibarzt des Großen Kurfürsten, Botaniker und Sinologe. Leipzig: Joh. Ambrosius Barth 1940. 44 S., 23 Abb. (Illustrierte Monographien zur Geschichte der Medizin 1.); Lothar Noack, Jürgen Splett: Bio-Bibliographien. Brandenburgische Gelebrte der Frühen Neuzeit. Berlin-Cölln 1640-1688. Berlin: Akademie Verlag 1997, 264-271.

6 Sylloge minutiarum Lexici latino-sinico-characteristici. Observatione sedula ex auctoribus \& lexicis Chinensium characteristicis eruta, inque Specimen primi laboris ulterius exantlandi erudito \& curioso orbi exposita. Norimbergae 1685. 20 fol.

${ }^{7}$ H. Walravens: Julius Klaproth (1783-1835). Leben und Werk. Wiesbaden: Harrassowitz 1999. X,230 S. (Orientalistik Bibliographien und Dokumentationen 3.)

${ }^{8}$ Verzeichniss der chinesischen und mandshuischen Bücher und Handschriften der Königlichen Bibliothek zu Berlin. Paris: Kgl. Druckerei 1822. VIII, 188, 63 p. $4^{\circ}$ (The catalogue was written in 1810.) 
ein eben so vollständiger für die Mandshuische, wie ihn keine Europäische Bibliothek, mit Ausnabme der zu Paris, besitz̧t.»

The supplementary catalogue by Wilhelm Schott adds only two Manchu works. ${ }^{9}$ We find major additions only towards the beginning of the 20th century. The Müller collection deserves special mentioning - books acquired by the department director of the Berlin Ethnological Museum F. W. K. Müller ${ }^{10}$ (1863-1930), in Peking in 1901. The Pekinger Sammlung is outstanding; «es handelt sich bei diesen Werken offensichtlich um Bücher aus der Kaiserlichen Bibliothek in Peking, die bei der Plünderung nach Europa gekommen waren.» They entered the Royal Library at first as a deposit of the «Kriegsverwaltung» and were finally accessioned as of the end of 1909, with agreement of the court administrator. ${ }^{11}$

The acquisition of the Möllendorff collection in 1911 was of major importance, as P. G. von Möllendorff had published his pioneering Essay on Manchu literature as the basis of Manchu Studies. ${ }^{12}$ Further additions were arranged by Erich Hauer ${ }^{13}$ (18781936), professor of Manchu at Berlin University, and resulted in 18 works so far missing ${ }^{14}$ as well as acquisitions by Walter Simon ${ }^{15}$ (1893-1981) in Peking in $1933^{16}$.

The period after WWII brought two major additions to the Manchu holdings the Haenisch ${ }^{17}$ collection with its focus on history and the Polevoj collection, largely teaching and exercise material (all in manuscript).

\section{Digitisation}

In the meantime the State Library (East Asian Dept.) entered on a major digitization project which aims at scanning the older Chinese collection, including the Kraków holdings, thus leading to a virtual unification, and mounting it on the net. This would include the Manchu (but not the Sibe) items. The project is progressing

\footnotetext{
9 御書房滿漢書廣錄V Verzeichniss der chinesischen und mandschu-tungusischen Bücher und Handschriften der Königlichen Bibliothek zи Berlin. Berlin: Kgl. Akademie der Wissenschaften 1840. IV, 120 pp.

${ }^{10}$ H. Walravens: Müller, Friedrich Wilhelm Karl. Neue Deutsche Biographie 18.1997, 381-382.

11 Guido Auster: Die Orientalische Abteilung. Deutsche Staatsbibliothek 1661-1961. 1. Geschichte und Gegenwart. Leipzig: VEB Verlag für Buch- und Bibliothekswesen 1961, 294.

${ }^{12}$ Essay on Manchu literature. By P. G. von Möllendorff. Journal of the North China Branch of the RAS $24.1890,1-45$.

${ }^{13}$ Erich Haenisch: Erich Hauer (1878-1936). ZDMG 107.1957, 1-6; H. Walravens: Sinologie in Berlin, 1890-1945: Otto Franke, Alfred Forke, Erich Hauer und Erich Haenisch. Schriftenverzeichnisse. Mit einem Beitrag von Martin Gimm über Walter Fuchs. Berlin: Staatsbibliothek 2010. 228 S. $4^{\circ}$ (Neuerwerbungen der Ostasienabteilung. Sonderheft 23.)

${ }^{14}$ Hermann Hülle: Neuerwerbungen cbinesischer und manjurischer Bücher in den Jabren 1921-1930. Leipzig: Hiersemann 1931, p. 34

15 C. R. Bawden: Ernst Julius Walter Simon. Proceedings of the British Academy 67.1981, 459-477.

16 Auster, a.a.O., 1961, p. 296.

17 Wolfgang Bauer: Erich Haenisch (1880-1966). ZDMG 117.1967, 205-210, Porträt; H. Walravens: Sinologie in Berlin, 1890-1945: Otto Franke, Alfred Forke, Erich Haner und Erich Haenisch. Schriftenverzeichnisse. Berlin: Staatsbibliothek 2010. 228 p. $4^{\circ}$
} 
but will probably take more time than anticipated. While there has been ample experience with Western language material, the Chinese collection is fragmentary, often fragile, contains mss., needs more quality control, and above all language expertise. These are certainly retarding elements. There is also a need for identifying chapters, sections etc. and arranging the metadata for the needs of online presentation. Considering the fact that some Manchu texts of the Paris collection and a few Manchu dictionaries of East Asian provenance are already available on the internet the future online offer may be quite attractive for students of Manchu. Erwin von Zach ${ }^{18}$ (1872-1942) the eminent lexicographer and translator of Chinese poetry suggested already a hundred years ago to make books like the Gin ping mei bithe available to interested parties instead of the dry as dust ethical Confucian tracts, and Manchu Studies would experience an upsurge!

Additional note, Aug 2016:

The catalogue was published in the meantime: Chinesische und manjurische Handschriften und seltene Drucke: Teil 8: Mandschurische Handschriften und Drucke im Bestand der Staatsbibliothek qu Berlin. Stuttgart: Steiner 2014. 560 pp. (VOHD XII,8.) ISBN 978-3-515-10756-3.

18 Critical linguist and translator, especially of Chinese classical poetry, cf. on him Alfred Hoffmann: Dr. Erwin Ritter von Zach (1872-1942). Oriens Extremus 10.1963, 1-60. 
In October 2014 about thirty scholars from Asia and Europe came together for a conference to discuss different kinds of sources for the research on Central Asia. From museum collections and ancient manuscripts to modern newspapers and pulp fiction and the wind horses flying against the blue sky of Mongolia there was a wide range of topics. Modern data processing and data management and the problems of handling five different languages and scripts for a dictionary project were leading us into the modern digital age. The dominating theme of the whole conference was the importance of collections of source material found in libraries and archives, their preservation and expansion for future generations of scholars. Some of the finest presentations were selected for this volume and are now published for a wider audience. 